ORNL/TM-13478
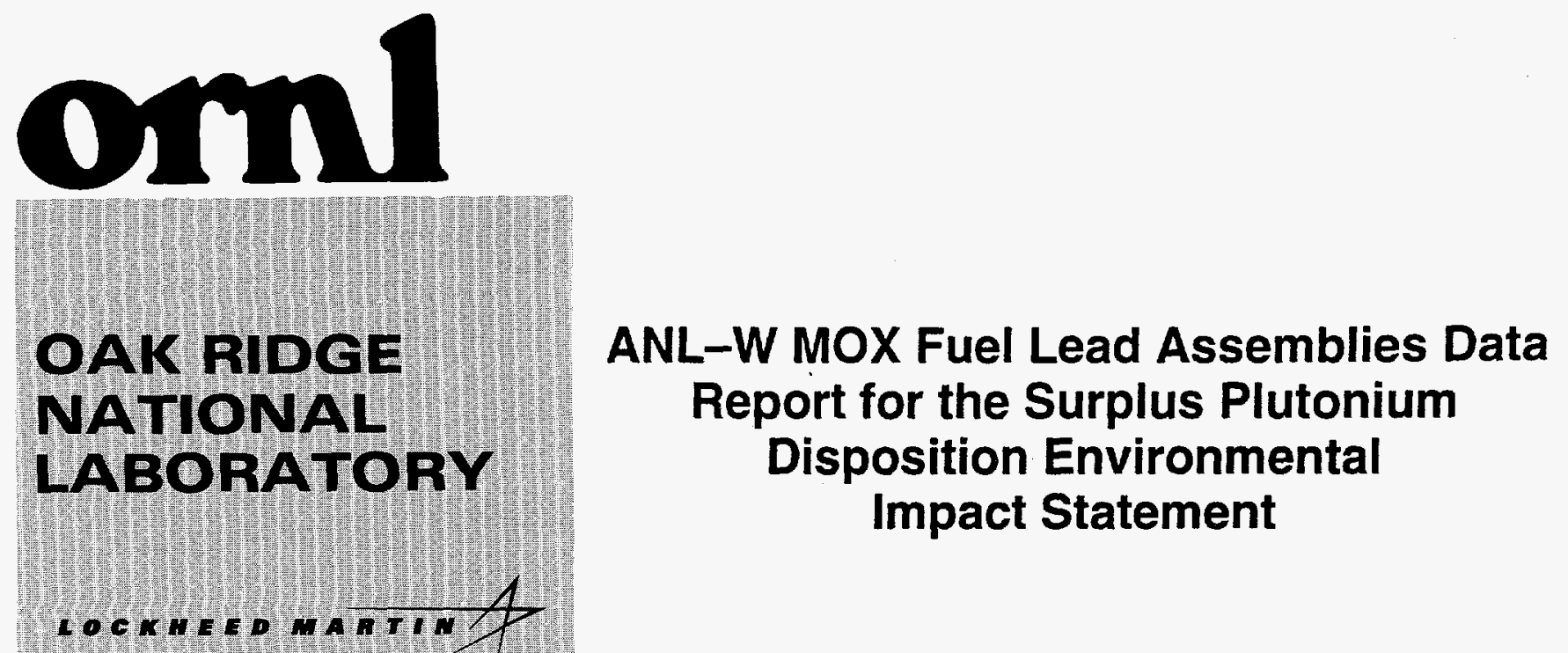

Fissile Materials Disposition Program

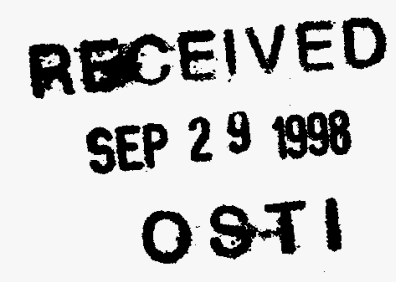

WANAGED AND OPEERATED BY

LOCKHEEO UARTW ENERGY RESEARCH CORPORATION FOATHE UHTEO STATES

DEPARTMENT OF ENERGY

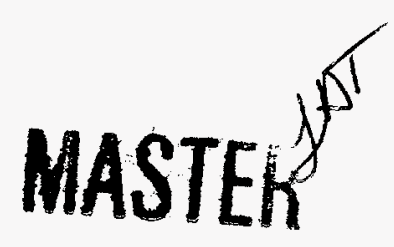

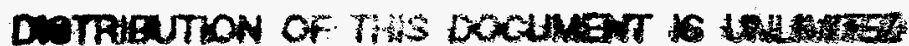


This report has been reproduced directly from the best available copy.

Available to DOE and DOE contractors from the Office of Scientific and Technical Information, P.O. Box 62, Oak Ridge, TN 37831; prices available from (423) 576-8401.

Available to the public from the National Technical Information Service, U.S. Department of Commerce, 5285 Port Royal Rd., Springfield, VA 22161.

This report was prepared as an account of work sponsored by an agency of the United States Government. Neither the United States Government nor any agency thereof, nor any of their employees, makes any warranty, express or implied, or assumes any legal liability or responsibility for the accuracy, completeness, or usefulness of any information, apparatus, product, or process disclosed, or represents that its use would not infringe privately owned rights. Reference herein to any specific commercial product, process, or service by trade name, trademark, manufacturer, or otherwise, does not necessarily constitute or imply its endorsement, recommendation, or favoring by the United States Government or any agency thereof. The views and opinions of authors expressed herein do not necessarily state or reflect those of the United States Government or any agency thereof. 


\section{DISCLAIMER}

This report was prepared as an account of work sponsored by an agency of the United States Government. Neither the United States Government nor any agency thereof, nor any of their employees, makes any warranty, express or implied, or assumes any legal liability or responsibility for the accuracy, completeness, or usefulness of any information, apparatus, product, or process disclosed, or represents that its use would not infringe privately owned rights. Reference herein to any specific commercial product, process, or service by trade name, trademark, manufacturer, or otherwise does not necessarily constitute or imply its endorsement, recommendation, or favoring by the United States Government or any agency thereof. The views and opinions of authors expressed herein do not necessarily state or reflect those of the United States Government or any agency thereof. 


\section{DISCLAIMER}

Portions of this document may be illegible in electronic image products. Images are produced from the best available original document. 


\title{
ANL-W MOX FUEL LEAD ASSEMBLIES DATA REPORT FOR THE SURPLUS PLUTONIUM DISPOSITION ENVIRONMENTAL IMPACT STATEMENT
}

\section{Project Manager}

S. R. Greene

Lead Assembly EIS Data Project Lead and Author

D. G. O'Connor

\section{Contributing Authors}

\section{ORNL}

S. E. Fisher

R. Holdaway

S. B. Ludwig

R. Morris

R. R. Rahn

J. Sease

V.S. White

K. L. McElhaney

J. J. Carbajo
ANL-W

D. Crawford

M. Klossner

S. Martinez

Date Published: August 1997

\author{
Prepared by \\ OAK RIDGE NATIONAL LABORATORY \\ Oak Ridge, Tennessee 37831 \\ managed by \\ LOCKHEED MARTIN ENERGY RESEARCH CORP. \\ for the \\ U.S. DEPARTMENT OF ENERGY \\ under contract DE-AC05-96OR22464
}


Page Intentionally Blank 


\section{CONTENTS}

LIST OF FIGURES

$v$

LIST OF TABLES

ACRONYMS

ABSTRACT.

1. INTRODUCTION AND SCHEDULE.

2. SITE MAP AND THE LA FACILITY DESCRIPTION.

2.1 SITE LOCATION.

2.2 DISCUSSION OF FACILITIES

2.2.1 Description of Buildings

2.2.2 Current Activities and Uses of the ZPPR/FMF/FASB Complex.

2.2.3 Special Equipment or Structural Elements of the ZPPR/FMF/FASB Complex

2.2.4 Security Features

2.2.5 Filtration Systems for the ZPPR/FMF/FASB Complex

2.2.6 Specific Space in the ZPPR/FMF Complex to be Allocated to the LTA Mission

2.2.7 Other ANL-W and INEEL Facilities That Could Support the LTA Mission...............

2.2.8 Facility Modifications..

3. PROCESS DESCRIPTIONS

3.1 PROCESS FLOW DIAGRAM.

3.2 WASTE MANAGEMENT FLOW DIAGRAMS

4. RESOURCE NEEDS.

4.1 CONSTRUCTION RESOURCE NEEDS

4.2 OPERATIONAL RESOURCE NEEDS

4.2.1 Utilities

4.2.2 Fuel Resources.

4.2.3 Water.

4.2.4 Process and Nonprocess Chemicals and Compounds

4.2.5 Radioactive Process Materiais.

5. EMPLOYMENT REQUIREMENTS.

5.1 ANNUAL EMPLOYMENT REQUIREMENTS DURING OPERATION

OF THE LA FABRICATION FACILITY

5.2 RADIATION DOSES (WHOLE BODY) TO INVOL VED WORKERS

DURING MODIFICATION OF THE LA FABRICATION FACILITY

5.3 RADIATION DOSES (WHOLE BODY) TO INVOLVED WORKERS

DURING OPERATION OF THE LA FABRICATION FACILITY

6. WASTES, EMISSIONS, AND EXPOSURES

6.1 WASTES GENERATED DURING FACILITY MODIFICATION.

6.1.1 Wastes.

6.1.2 Emissions.

6.1.3 Exposures

6.2 WASTES GENERATED DURING OPERATION OF THE FACILITY...

7. ACCIDENT ANALYSIS.

7.1 INTRODUCTION

7.2 GENERAL APPROACH AND GENERIC DESIGN ASSUMPTIONS

7.2.1 Accident Analysis Approach.

7.2.2 Facility Design Assumptions.

7.3 SELECTED EVENTS FOR THE LA EIS ANALYSIS.

7.3.1 Criticality Event. 
7.3.2 Evaluation Basis Seismic Event........................................................................................... 45

7.3.3 Evaluation Basis Fire Event ................................................................................................... 47

7.3.4 Evaluation Basis Explosion Event.................................................................................................. 49

7.3.5 Beyond-Evaluation Basis Seismic Event ............................................................................. 51

7.3.6 Beyond-Evaluation Basis Major Building Fire....................................................................... 51

7.4 EVALUATION OF POTENTIAL CHEMICAL SOURCE TERMS........................................... 53

7.5 SITE SPECIFICS FOR THE ANL BUILDING 704 ....................................................................... 53

7.5.1 Stack Release Height .............................................................................................................................. 53

7.5.2 Evaluated Seismic Attributes................................................................................................. 53

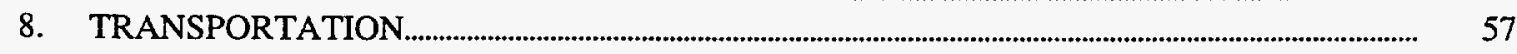

8.1 OPERATIONS-RELATED TRANSPORTATION REQUIREMENTS ……............................ $\quad 57$

8.1.1 Feed Materials .............................................................................................................. 57

8.1.2 Fresh MOX Fuel Assemblies.............................................................................................. 57

8.1.3 Spent MOX Fuel Assemblies ........................................................................................................... $\quad 57$

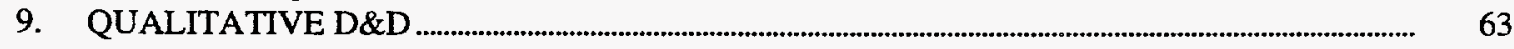

9.1 INTRODUCTION...................................................................................................................................................... 63

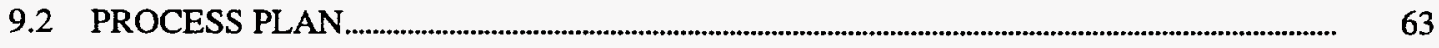

9.3 D\&D OPERATIONS ............................................................................................................... $\quad 63$

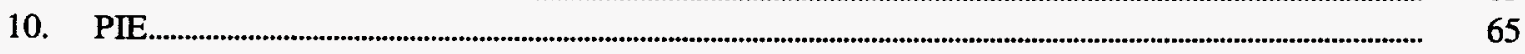

10.1 PIE DISCUSSION

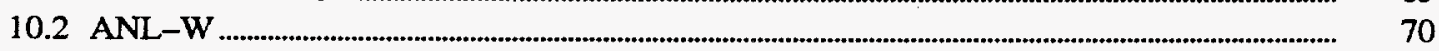

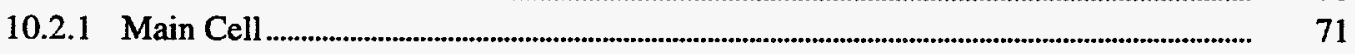

10.2.2 Decon Cell....................................................................................................................... $\quad 71$

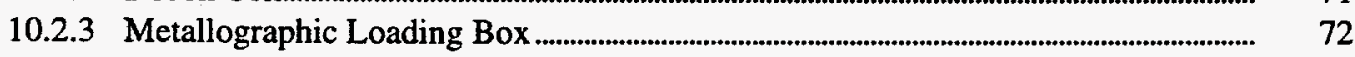

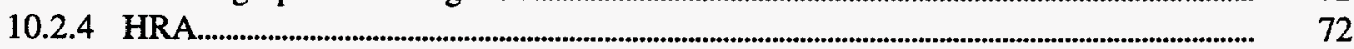

10.2 .5 WCA.

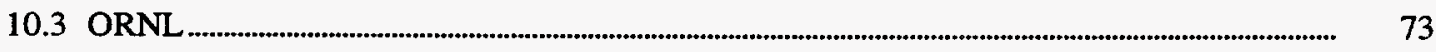

REFERENCES ……............................................................................................................................. $\quad 77$

APPENDIX A-LA FUEL BUNDLE FABRICATION ........................................................................ A-1

APPENDIX B -LA EIS DATA REPORT ASSUMPTIONS................................................................................ B-1

SUPPLEMENT_LA EIS DATA REPORT SUPPLEMENT ................................................................................ S S-1 


\section{LIST OF FIGURES}

Figure

Page

$1 \quad$ Simplified LA process diagram.............................................................................................................

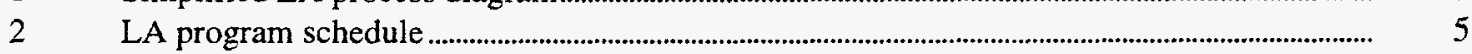

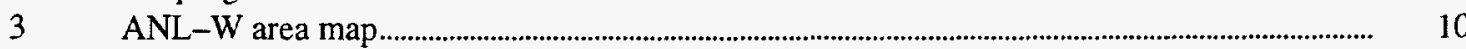

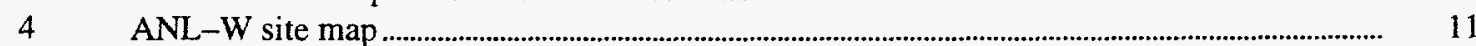

$5 \quad$ LA MOX fuel flow sheet outline with annual throughputs ...........................................................

6. Waste generated during LA MOX fuel fabrication facility operation.............................................. 20

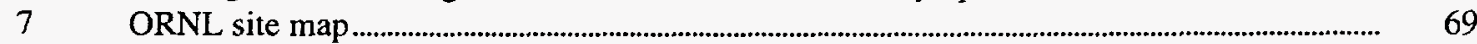

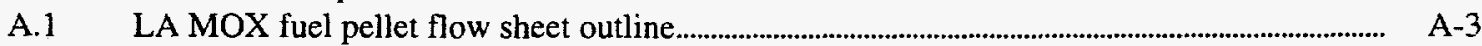

A.2 LA MOX fuel $\mathrm{PuO}_{2}$ powder receipt and storage..................................................................................... A-4

A.3 Detailed flow sheet of LA pellet fabrication ......................................................................................... A-5

A.4 Detailed flow sheet of LA rod fabrication …….................................................................... A-6

A.5 Detailed flow sheet of LA bundle assembly (LWR) ....................................................................... A-7 
Page Intentionally Blank 


\section{LIST OF TABLES}

Table

LA fabrication facility schedule...

LA testing schedule.

LA MOX fuel material requirements.

Assumptions made to determine LA MOX fuel material requirements........................................ $\quad 7$

LA MOX fuel fabrication requirements ................................................................................................. $\quad 19$

Resource needs for modifications of FMF and ZPPR facilities .................................................... 23

Resource needs during operation of the LA fabrication facility.................................................... $\quad 26$

Annual employment requirements during operation of the LA fabrication facility.................. $\quad 32$

Assumptions used in consideration of staffing levels for the LA fabrication facility............. $\quad 32$

Employment needs during modification of the LA fabrication facility.......................................... 33

Radiation doses (whole body) to involved workers during operation of the

LA fabrication facility.

Estimated waste generated during operation of the LA fabrication facility.................................. $\quad 36$

Specific activities for process powders.

Estimated maximum station inventories for LA fabrication plant.

Source term for the evaluation basis criticality event............................................................................. $\quad 45$

Source term for the evaluation basis seismic event................................................................................. $\quad 46$

Source term for the evaluation basis fire ..................................................................................................... 48

Source term for the evaluation basis explosion............................................................................... 50

Source term for beyond the evaluation basis seismic event ............................................................. 52

Source term for beyond the evaluation basis major building fire/building collapse ................. 54

Comparison of LA facility annual usage and reportable quantity per 40 CFR 302 .................. $\quad 55$

Transportation of $\mathrm{PuO}_{2}$ to support LA fabrication ............................................................................ 58

Transportation of depleted $\mathrm{UO}_{2}$ to support LA fabrication ........................................................... 58

Transportation of materials to support LA fabrication (LEU) fuel assemblies......................... $\quad 59$

Transportation of LAs to generic reactor site....................................................................................... 59

Fresh MOX fuel isotopic content .............................................................................................................. 60

Transportation of irradiated LAs to PIE site .................................................................................... $\quad 60$

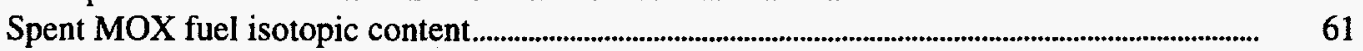

Examples of casks for LWR spent fuel............................................................................................... 62

Estimated waste generated during the LA PIE............................................................................................ $\quad 66$

Radiation doses to involved workers during the LA PIE....................................................................... 67

PIE estimates for EIS ........................................................................................................................ 67

B-1 Assumptions used for the LA EIS data reports ...................................................................................... B-3 


\section{Page Intentionally Blank}




\section{ACRONYMS}

ACL

AEC

AL

ALARA

ANL-W

ARF

ASTM

BRET

BWR

CAA

CCCTF

CEDE

CERCLA

CFA

CFR

$\mathrm{CH}$

CMC

CMR

CRBR

CS

CST

CWA

D\&D

$D \& R$

DBA

dc

DOE

DWPF

EA

EBR-I

EBR-II

EIS

EJ

EPA

ER

ETB

FAA

FASB

FCF

FCFS

FEMA

FFTF

FMEF

FMF

FONSI

FR

FTE

HAP

HEPA

HEU administrative control level

U.S. Atomic Energy Commission

analytical laboratory

as low as reasonably achievable

Argonne National Laboratory-West (at INEEL)

airborne release fraction

American Society for Testing and Materials

Breeder Reprocessing Engineering Test

boiling-water reactor

Clean Air Act

Core Conduction Cooldown Test Facility

committed effective dose equivalent

Comprehensive Environmental Response, Compensation, and Liability Act of 1980

Central Facilities Area (ANL-W)

Code of Federal Regulations

contact-handled

confirmatory measurement counter

Chemistry and Metallurgy Research

Clinch River Breeder Reactor

containment and surveillance

Chemical Science and Technology

Clean Water Act of 1972

decontamination and decommissioning

dismantling and rearrangement

design-basis accident

direct current

U.S. Department of Energy

defense waste processing facility

environmental assessment

Experimental Breeder Reactor-I

Experimental Breeder Reactor-II

environmental impact statement

environmental justice

Environmental Protection Agency

Environmental Report

Engineering Test Bay

Fuel Assembly Area

Fuel Assembly and Storage Building

Fuel Cycle Facility

Fueled Clad Fabrication System

Federal Emergency Management Agency

Fast-Flux Test Facility

Fuels and Materials Examination Facility

Fuel Manufacturing Facility

finding of no significant impact

fire resistive

full-time equivalent

hazardous air pollutant

high-efficiency particulate air

highly enriched uranium 


\begin{tabular}{|c|c|}
\hline $\mathrm{HFEF} / \mathrm{S}$ & Hot Fuel Examination Facility South \\
\hline HM & heavy metal \\
\hline $\mathrm{HP}$ & Health Physics \\
\hline HPFL & High-Performance Fuel Laboratory \\
\hline HVAC & heating, ventilating, and air conditioning \\
\hline HWMA & Hazardous Waste Management Act of 1983 \\
\hline I\&C & Instrumentation and Controls \\
\hline IDAPA & Idaho Administrative Procedures Act \\
\hline IFEL & Irradiated Fuels Examination Laboratory \\
\hline IFR & Integral Fast Reactor \\
\hline IMGA & Irradiated Microsphere Gamma Analyzer \\
\hline INEEL & Idaho National Engineering and Environmental Laboratory \\
\hline INRAD & Intrinsic Radiation Bay \\
\hline LA & lead assembly \\
\hline LACEF & Los Alamos Critical Experiments Facility \\
\hline LANL & Los Alamos National Laboratory \\
\hline LLMW & low-level mixed waste \\
\hline LLRW & low-level radioactive waste \\
\hline LLW & low-level waste \\
\hline LLNL & Lawrence Livermore National Laboratory \\
\hline LMES & Lockheed Martin Energy Systems, Inc. \\
\hline LMITCO & Lockheed Martin Idaho Technologies Company \\
\hline LTA & lead-test assembly \\
\hline LUA & lead-use assembly \\
\hline LWR & light-water reactor \\
\hline MAA & Material Access Area \\
\hline $\mathrm{M} \& \mathrm{C}$ & Metals and Ceramics \\
\hline MC\&A & material control and accountability \\
\hline MD & Office of Fissile Materials Disposition (DOE) \\
\hline MFP & multiple fission products \\
\hline MOX & mixed oxide \\
\hline MT & metric ton \\
\hline MW & mixed waste \\
\hline NDA & nondestructive assay \\
\hline NDT & nondestructive testing \\
\hline NEPA & National Environmental Policy Act of 1969 \\
\hline NGVD & National Geodetic Vertical Datum \\
\hline NMS\&S & Nuclear Material Stabilization and Storage Division \\
\hline NMSS & Office of Nuclear Material Safety and Safeguards \\
\hline NPDES & National Pollutant Discharge Elimination System \\
\hline NRC & Nuclear Regulatory Commission \\
\hline ORNL & Oak Ridge National Laboratory \\
\hline ORR & Oak Ridge Reservation \\
\hline PA & protected area \\
\hline PDAC & pit disassembly and conversion \\
\hline PF & Plutonium Facility \\
\hline PFP & Plutonium Finishing Plant \\
\hline PIDAS & Perimeter Intrusion and Detection Assessment System \\
\hline PIE & postirradiation examination \\
\hline PPE & personal protective equipment \\
\hline PSF & Plutonium Storage Facility \\
\hline PWR & pressurized-water reactor \\
\hline QA & quality assurance \\
\hline R\&D & research and development \\
\hline
\end{tabular}




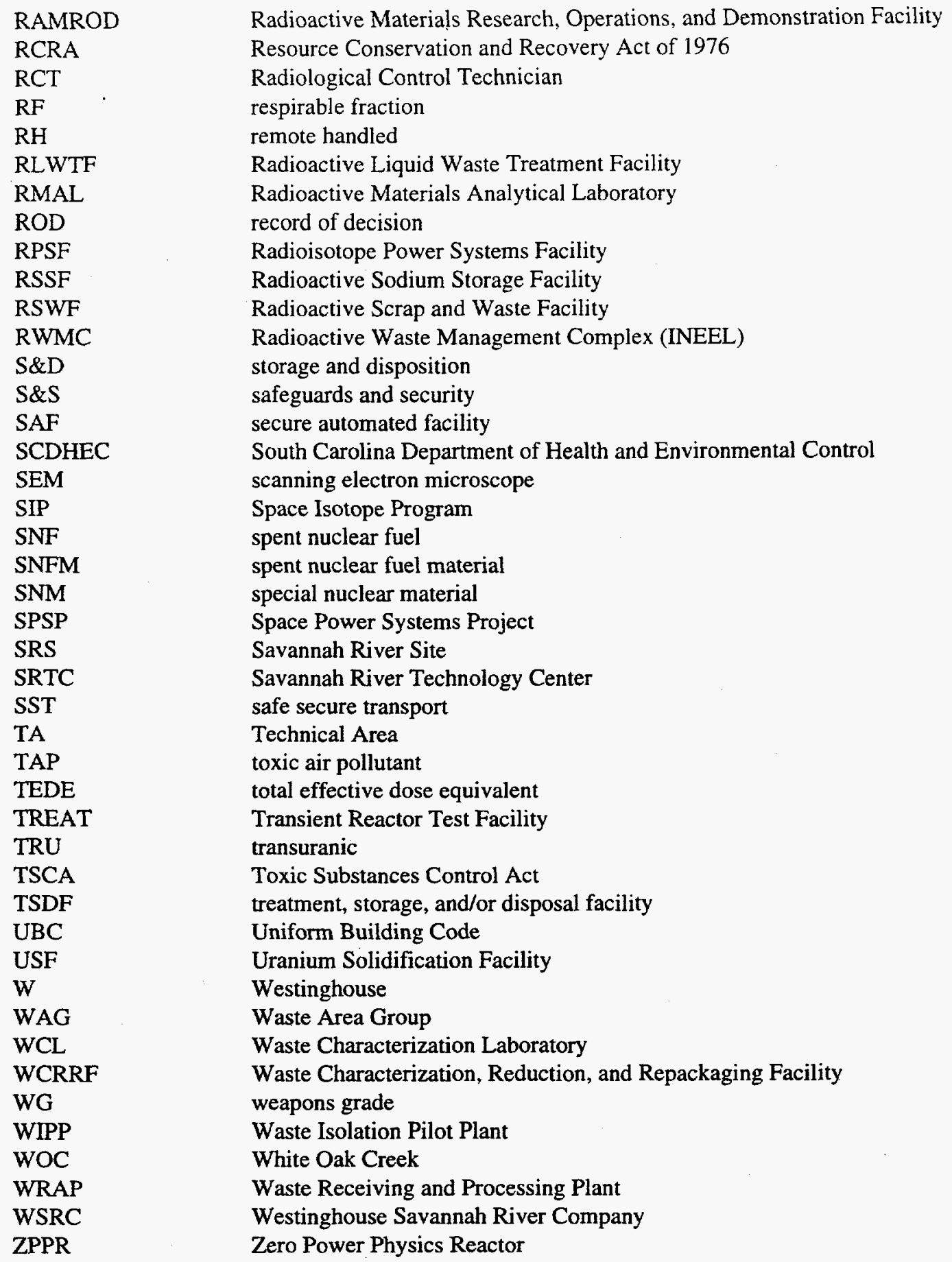


Page Intentionally Blank 


\title{
ANL-W MOX FUEL LEAD ASSEMBLIES DATA REPORT FOR THE SURPLUS PLUTONIUM DISPOSITION ENVIRONMENTAL IMPACT STATEMENT
}

\author{
Project Manager \\ S. R. Greene \\ Lead Assembly EIS Data Project Lead and Author \\ D. G. O'Connor
}

\begin{abstract}
The purpose of this document is to support the U.S. Department of Energy (DOE) Fissile Materials Disposition Program's preparation of the draft surplus plutonium disposition environmental impact statement. This is one of several responses to data call requests for background information on activities associated with the operation of the lead assembly (LA) mixed-oxide (MOX) fuel fabrication facility.

The DOE Office of Fissile Materials Disposition (DOE-MD) has developed a "dual-path" strategy for disposition of surplus weapons-grade plutonium. One of the paths is to disposition surplus plutonium through irradiation of MOX fuel in commercial nuclear reactors. MOX fuel consists of plutonium and uranium oxides $\left(\mathrm{PuO}_{2}\right.$ and $\left.\mathrm{UO}_{2}\right)$, typically containing $95 \%$ or more $\mathrm{UO}_{2}$.

DOE-MD requested that the DOE Site Operations Offices nominate DOE sites that meet established minimum requirements that could produce MOX LAs. Six initial site combinations were proposed: (1) Argonne National Laboratory-West (ANL-W) with support from Idaho National Engineering and Environmental Laboratory (INEEL), (2) Hanford, (3) Los Alamos National Laboratory (LANL) with support from Pantex, (4) Lawrence Livermore National Laboratory (LLNL), (5) Oak Ridge Reservation (ORR), and (6) Savannah River Site (SRS). After further analysis by the sites and DOE-MD, five site combinations were established as possible candidates for producing MOX LAs: (1) ANL-W with support from INEEL, (2) Hanford, (3) LANL, (4) LLNL, and (5) SRS. Pantex was removed as a supporting organization to LANL because Pantex did not have facilities available that met the desired programmatic criteria. One of the criteria was that existing buildings would be used for the mission. Pantex had no available existing buildings that it was willing to propose for this limited mission. ORR was removed by DOE-MD from consideration because it lacked adequate Safeguards and Security (S\&S) Category I facilities, which would limit the quantity of material that could be processed at a given time.

Buildings 775 and 776, which house the Zero Power Physics Reactor facility, would be used for the program after removal of the stainless steel matrix and support structure that made up the core. This would be a relatively simple activity because the structures are all bolted together. Building 704, which houses the Fuel Manufacturing Facility, would require removal of existing glove boxes and equipment to accommodate LA MOX fuel fabrication.

A commercial reactor operator has not been identified for irradiation of the LAs. Postirradiation examination (PIE) of the irradiated fuel will take place at either Oak Ridge National Laboratory or ANL-W. The only modifications required at either PIE site would be to accommodate full-length irradiated fuel rods.

Results from this program are critical to the overall plutonium disposition program schedule.
\end{abstract}


Page Intentionally Blank 


\section{INTRODUCTION AND SCHEDULE}

As part of the overall mission to disposition weapons-grade (WG) plutonium as fuel for commercial nuclear power plants, a lead assembly (LA) program is needed to qualify mixed-oxide (MOX) fuel as a safe and reliable fuel. The LA program will provide key data regarding the performance of MOX fuel in U.S. commercial reactors and supply information needed to modify current U.S. Nuclear Regulatory Commission (NRC) licenses. The program will also provide information necessary to validate and verify computer codes used in the reactor core design and accident analyses. In addition to qualifying the MOX fuel and validating and verifying the codes, the LA program will serve to verify that the United States can indeed execute each technical step necessary in the process of dispositioning plutonium as MOX fuel, except NRC licensing of facilities.

A simplified diagram showing each of the required process steps for the LA program is shown in Fig. 1. The LA program will include every step needed to complete the reactor portion of the plutonium disposition mission (including transportation and storage), with the exception of placement of the spent fuel in the geologic repository. In all likelihood, some of the LA program MOX fuel bundles will make their way to the geologic repository, but subsequent disposal in the repository is analyzed in other environmental documents. Detailed descriptions of the process required to fabricate MOX fuel, irradiate the fuel, and perform postirradiation examinations (PIE) of the spent fuel will be provided in Chaps. 3 and 10.

As previously stated, the goals of the LA program are to qualify the MOX fuel, confirm codes, and demonstrate that the United States can perform the steps necessary to disposition plutonium using MOX fuel. For the LA program these steps start with receipt of acceptable plutonium oxide $\left(\mathrm{PuO}_{2}\right)$ that is derived from "pits" and processed in the United States. At each step in the process, safeguards and security (S\&S) measures, material control and accountability (MC\&A) measures, transportation issues, storage issues, and material handling issues will be addressed. As shown in Fig. 1, the $\mathrm{PuO}_{2}$ is mixed and blended with

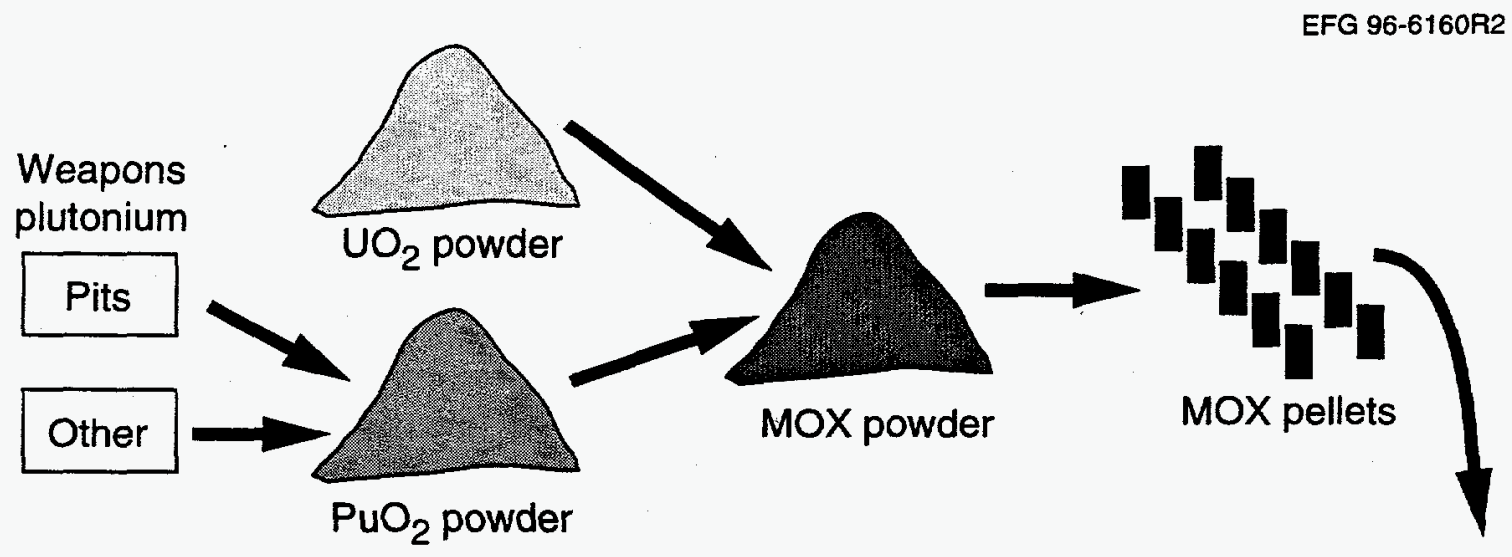

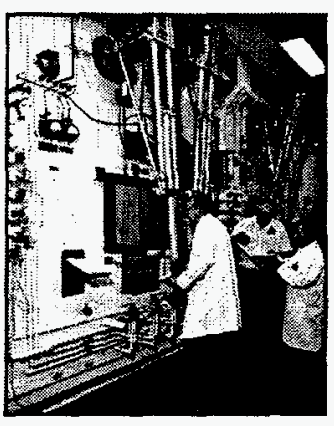

PIE

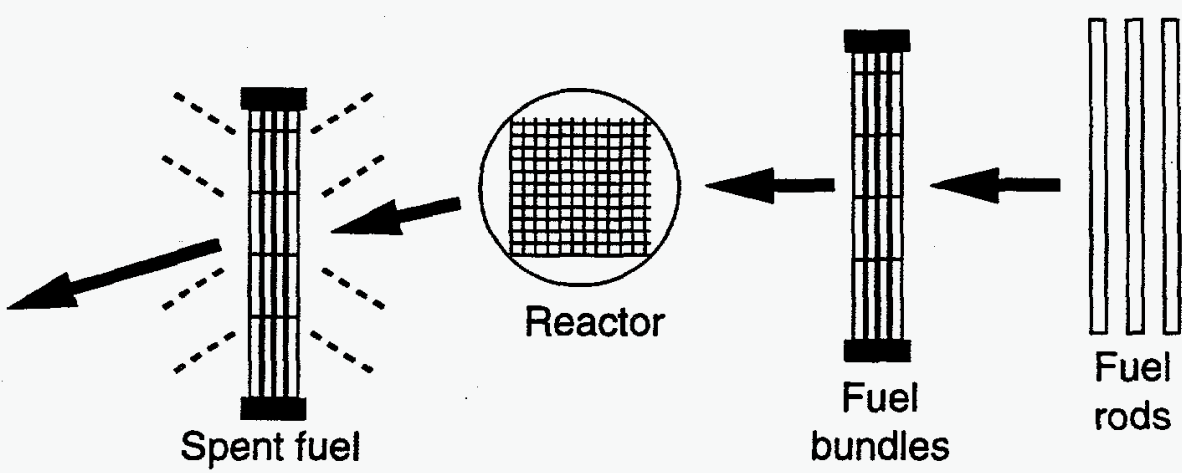

Fig. 1. Simplified LA process diagram. 
uranium oxide $\left(\mathrm{UO}_{2}\right)$ to arrive at the fissile content requested by the utility fuels engineer. Pellets are then pressed, sintered, and assembled into rods. The rods are then assembled into fuel assemblies and packaged for shipping to the reactor site for irradiation. After irradiating the fuel for one cycle, some of the rods are removed from the irradiated assemblies and taken to a laboratory for PIE. Additional rods will be removed after the second, third, and fourth cycles (if the chosen reactor has a third and fourth cycle), and PIE will be performed to confirm that the structural integrity of the MOX fuel, cladding, and assembly materials is maintained and that the computer codes accurately predict the fuel performance and evolution of fission products.

Figure 2 shows the anticipated schedule for the LA program relative to the plutonium disposition mission. Los Alamos National Laboratory (LANL) is currently developing the processes necessary to fabricate MOX fuel. The U.S. Department of Energy Office of Fissile Materials Disposition (DOE-MD) plans to choose a consortium before the end of 1998 to disposition excess plutonium using reactors, at which time this consortium will choose the DOE site(s) and associated facilities to fabricate the LA MOX fuel. At that same time the consortium will begin design, licensing, and construction of the mission MOX fuel fabrication facility. The fabrication process used for the LAs will be as close as possible to that of the MOX fabricator in the consortium. Fabrication of the LA MOX fuel will begin in late 2002. The first LAs [shown as lead-test assemblies (LTAs) in Fig. 2] will be available for insertion in a commercial reactor in late 2003. PIE will begin 6 months after completion of the first reactor cycle with results available by the end of the second LA reactor cycle. After two LA cycles (18-24 months per cycle), the mission MOX fuel fabrication will begin if the PIE produces satisfactory confirmation of fuel performance. PIE will be done after each LA reactor cycle to ensure that fuel performance meets or exceeds expected results. Table 1 provides the schedules associated with the design, modification, operation, decontamination and decommissioning (D\&D), and/or conversion of the LA MOX fuel fabrication facility. Table 2 provides the time frames associated with the LA testing.

To maintain LA fabrication capability, should it be needed for any reason, the LA fuel fabrication facility will be maintained in standby for 4 years between the end of the facility's scheduled operation and its scheduled D\&D. During this time the capability to produce lead assemblies will be maintained.

A maximum of ten LAs will be produced to meet the LA program mission goals. Table 3 provides the anticipated quantities of constituent materials that will be needed annually and in total to complete the LA program. Several assumptions were made to arrive at the quantities in Table 3 , and these are listed in Table 4.

A total of four assemblies are anticipated to be required for use as LAs in the chosen mission reactor. It is possible a second set of four LAs will be needed for either a second reactor or for use in the same reactor. In addition, sufficient rods will be produced to assemble two archive LAs.

A total of eight LA MOX fuel assemblies will be temporarily stored in the LA fabrication facility until they are shipped to the reactors for irradiation. The rods for the two remaining assemblies, and possibly the MOX rods from four assemblies not used, will be retained in the LA shipping and storage area as archive rods. These archive rods will be used if needed as replacement rods in the reactor or they may be used for tests of the LA MOX fuel fabrication process. If they are not needed, or until they are needed, these rods will be stored at the LA MOX fuel fabrication facility until the end of that facility's mission. The LAs will then be shipped to the mission MOX fabrication facility for storage until the end of the Fissile Materials Disposition Program, at which time they will either be retained by the consortium as active rods, or irradiated in a mission reactor.

Due to the uncertainty associated with the final design of the LA MOX fuel, the assemblies may consist of either all MOX fuel rods or a combination of low-enriched uranium (LEU) and MOX rods. A bounding approach was taken in considering environmental impacts. The bounds that were considered for this report were based on the number of MOX fuel rods per assembly. A lower bound of one-third of the fuel rods being MOX rods results in the need to ship the remaining two-thirds of the required LEU rods to the LA fuel fabrication facility. The upper bound of all MOX rods in the assembly provides the bounding case for resource needs, safety considerations, accident analyses, and postirradiation examination. 
ORNL-DWG 97-1915R3 EFG

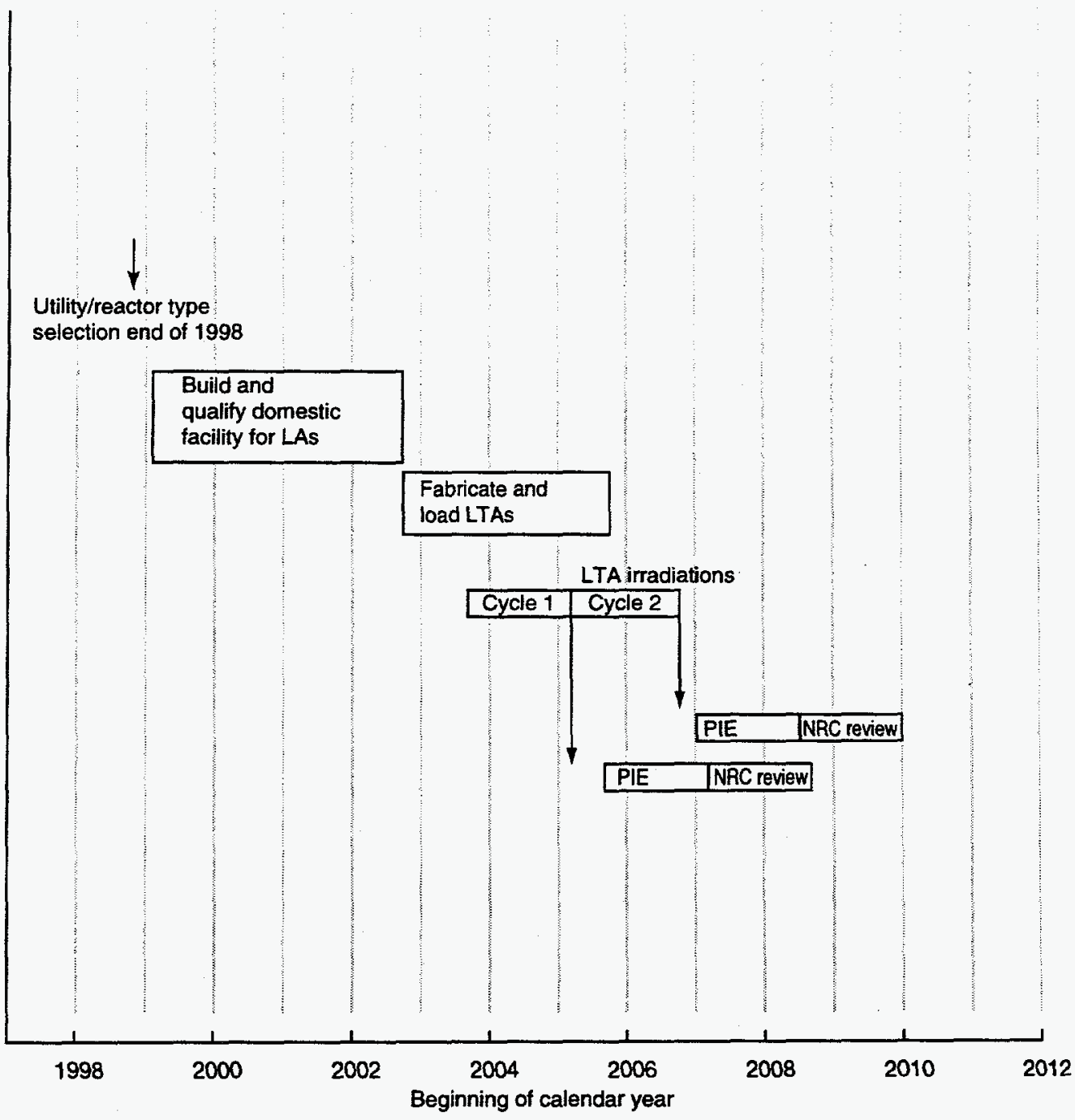

Fig. 2. LA program schedule. 
Table 1. LA fabrication facility schedule

\begin{tabular}{|c|c|}
\hline Activity & $\begin{array}{l}\text { Time frame } \\
\text { (beginning and end) }\end{array}$ \\
\hline Equipment procured & June 2000-December 2001 \\
\hline Facility design & February 1999-January 2001 \\
\hline Facility permitting & January $2000-J a n u a r y ~ 2002$ \\
\hline Facility modification & January $2000-F e b r u a r y ~ 2002$ \\
\hline Facility startup & February 2002-October 2002 \\
\hline LA fabrication (operation) & October 2002-October 2005 \\
\hline LA fabrication facility standby & October 2005-January 2010 \\
\hline D\&D and/or conversion phase & January 2010-January 2013 \\
\hline
\end{tabular}

Table 2. LA testing schedule

\begin{tabular}{ll}
\hline \multicolumn{1}{c}{ Activity } & \multicolumn{1}{c}{ Time frame (beginning and end) } \\
\hline Irradiation & $\begin{array}{l}\text { September 2003-October 2006 } \\
\text { Removal (cooldown) }\end{array}$ \\
$\begin{array}{l}\text { March 2005-October 2006 (6 months cooldown after removal } \\
\text { before PIE, March 2005-April 2007) } \\
\text { PIE }\end{array}$ & $\begin{array}{l}\text { September 2005-October 2008 (about 18 months for PIE for each } \\
\text { reactor cycle) }\end{array}$ \\
\hline
\end{tabular}

Table 3. LA MOX fuel material requirements

\begin{tabular}{lccccr}
\hline \multicolumn{1}{c}{ Material } & $\begin{array}{c}\text { Startup } \\
\text { requirement }\end{array}$ & $\begin{array}{c}\text { Startup } \\
\text { scrap/recyclable }\end{array}$ & $\begin{array}{c}\text { Maximum } \\
\text { annual } \\
\text { requirement }\end{array}$ & $\begin{array}{c}\text { Maximum } \\
\text { annual scrap/ } \\
\text { recyclable }\end{array}$ & $\begin{array}{c}\text { Total } \\
\text { quantity }\end{array}$ \\
\hline $\begin{array}{l}\text { Plutonium, kg } \\
\text { heavy metal (HM) }\end{array}$ & 21 & 13 & 120 & 20 & 321 \\
$\begin{array}{l}\text { Depleted uranium, } \\
\text { kg HM }\end{array}$ & 867 & 250 & 2,400 & 400 & 6,867 \\
$\begin{array}{l}\text { Pellets } \\
\text { Rods }\end{array}$ & 221,760 & & 532,224 & & $1,552,320$ \\
Bundles & 440 & & 1,162 & & 3,344 \\
\end{tabular}

Note: In the event LEU rods are used in place of some MOX rods in the assembly, the total quantities of plutonium will be reduced by the amount of LEU introduced. The maximum contribution of LEU rods is twothirds of the total assembly rods. 
Table 4. Assumptions made to determine LA MOX fuel material requirements

1. Material and process requirements are based on producing pressurized-water reactor (PWR) fuel.

2. $\mathrm{PuO}_{2}$ powder will meet the American Society for Testing and Materials (ASTM) specification C 757-90 as received.

3. Depleted $\mathrm{UO}_{2}$ powder will meet the ASTM specification as received.

4. Depleted $\mathrm{UO}_{2}\left(\right.$ no $\mathrm{PuO}_{2}$ ) will be used to perform all system shakedown tests before introducing plutonium.

5. Table 3 is in terms of $\mathrm{HM}$. The factor for converting $\mathrm{PuO}_{2}$ and depleted $\mathrm{UO}_{2}$ to $\mathrm{HM}$ is $88 \%$.

6. All waste plutonium will be canned and sent to the Immobilization Program for final disposition.

7. All plutonium scrap will be recycled using a dry process.

8. All liquid wastes generated are ancillary to the base process (i.e., laundry, mop water, etc.).

9. Sintering furnaces will stay at temperature during the entire 3-year mission and 1-year startup.

10. Sintering furnaces will be purged with a mixture of argon and $6 \%$ hydrogen at a rate of $10 \mathrm{~L} / \mathrm{min}$.

11. Powder glove boxes will be purged with nitrogen to reduce the potential for oxidizing $\mathrm{UO}_{2}$.

12. All calculated numbers have a precision of no more than two significant figures.

13. Homogenization of the $\mathrm{PuO}_{2}$ will be done at the LA fuel fabrication facility, as will gallium removal operations. 


\section{Page Intentionally Blank}




\section{SITE MAP AND THE LA FACILITY DESCRIPTION}

\subsection{SITE LOCATION}

An area map (Fig. 3$)^{1}$ shows the relative location of the ANL-W site with the INEEL site in Idaho. A site map (Fig. 4) shows the location of the Zero Power Physics Reactor (ZPPR)/Fuel Manufacturing Facility (FMF) Complex, the Argonne National Laboratory-West (ANL-W) Analytical Laboratory (AL) located in Building 752, and multiple waste facilities that would be used to support the lead test assembly (LTA) mission. Not shown but mentioned below are other Idaho National Engineering and Environmental Laboratory (INEEL) facilities operated by Lockheed Martin Idaho Technologies Company (LMITCO) that could also be used to support the ANL-W/INEEL LTA mission.

\subsection{DISCUSSION OF FACILITIES}

\subsubsection{Description of Buildings}

The ZPPR facility was built to allow the construction of full-sized breeder reactor critical assemblies using full plutonium loadings. To perform these experiments, ANL-W maintains $\sim 4$ tons of plutonium and half as much fully enriched uranium. During the peak of operation during the $1980 \mathrm{~s}$, it was not unusual for a small operating crew to handle more than $100 \mathrm{~kg}$ of plutonium in a single day. The facility includes a refined "Gravel Gertie" building, a type of construction originally designed for handling nuclear weapons. The principal experimental area has a very thick foundation and thick concrete walls covered with an earthen mound and a sand/gravel/high-efficiency particulate air (HEPA) filter roof. This type of construction helped make ZPPR not only the largest, but probably the most precise, reactor physics measurement facility in the world. In addition to being explosion-resistant, the facility was designed to contain a conflagration involving a full breeder reactor core loaded with more than 3 tons of plutonium. The stainless steel matrix and the support structure that made up the core can be simply unbolted and removed. The facility may have slight low-level waste (LLW) contamination (see Chap. 6).

The FMF facility is located adjacent to the ZPPR facility and is also buried under an earthen mound. FMF manufactured all the fuel for the Experimental Breeder Reactor-II (EBR-II) for much of its operating life. The facility was comfortably oversized for the EBR-II fuel mission and includes a large uranium vault, as well as other temporary experimental setups. Existing glove boxes and equipment may have to be removed, depending on the desired configuration for MOX LTA fabrication (see Chap. 6 for contamination information).

The Fuel Assembly and Storage Building (FASB), Building 787, will also be used in MOX LTA fabrication. FASB was constructed to provide space, equipment, and appropriate services for the manufacture of EBR-II fuel elements, driver and experimental subassemblies, and standard in-core components. The second major purpose of FASB was to provide a controlled vault storage facility for special nuclear material (SNM), fuel materials, and completed subassemblies. In addition, there are controlled storage areas for nonfueled subassemblies and hardware. The extreme west end of FASB houses a sophisticated metallurgical laboratory with scanning and transmission electron microscopes.

\subsubsection{Current Activities and Uses of the ZPPR/FMF/FASB Complex}

Gas generation experiments are being done at ZPPR to support Waste Isolation Pilot Plant (WIPP) performance, but this project will be completed before the facility would be needed to support the LTA mission.

FMF is currently supporting a furnace and glove box operation that is used to dismantle damaged ZPPR fuel plates and package the $\mathrm{PuO}_{2}$ that is recovered for shipment. This program will be completed prior to the LTA mission. The glove boxes can be removed or reused in the LTA program. The FMF facility is also used as a test site for developmental S\&S systems, including systems developed at LANL and Sandia. 
ORNL-DWG 97-3222 EFG

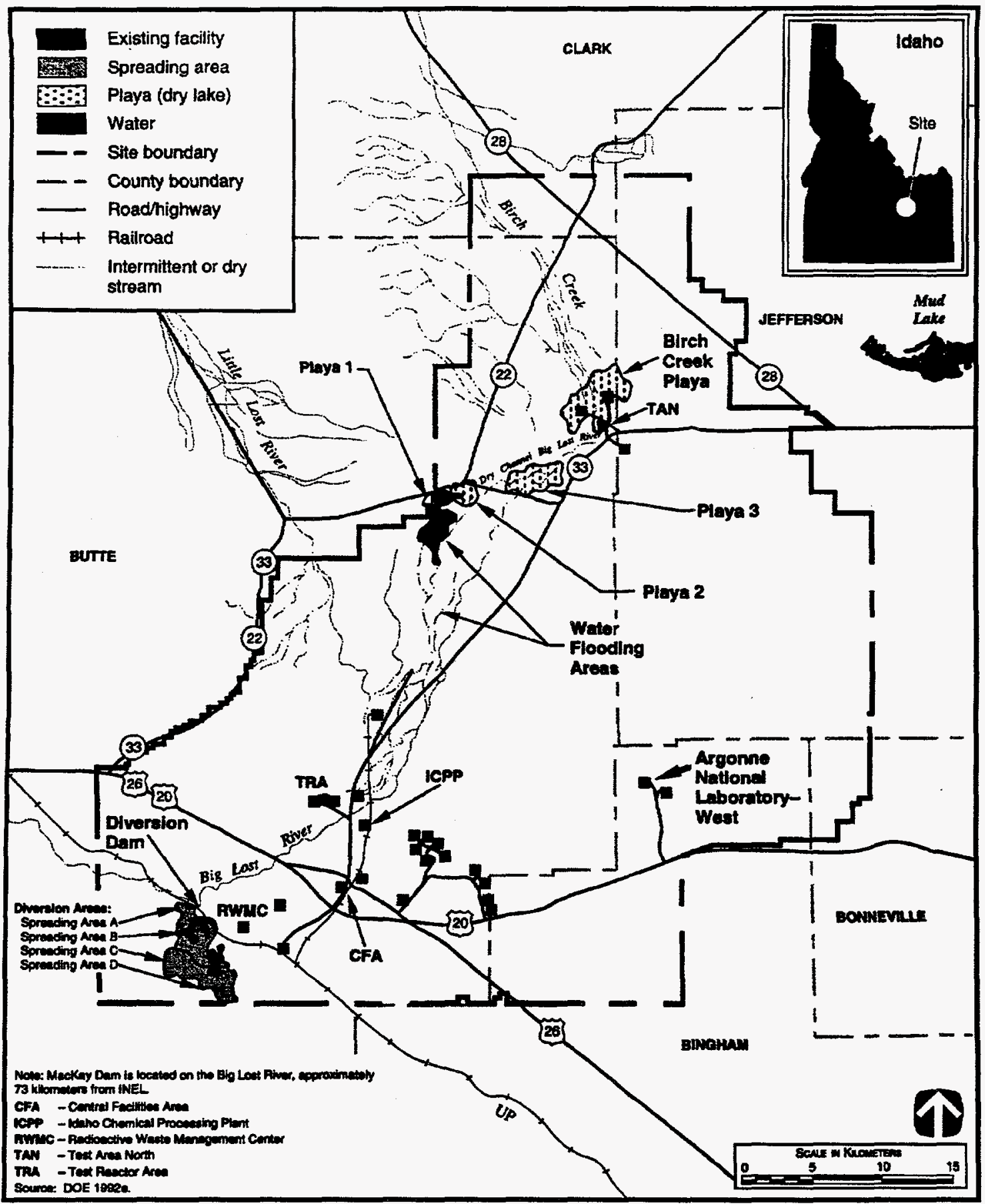

Fig. 3. ANL-W area map. Source: Storage and Disposition of Weapons-Usable Fissile Materials Final Programmatic Environmental Impact Statement, Vol. 1, DOE/EIS-0229, U.S. Department of Energy, December 1996. 
704 Fuel Manufacturing Facility (FMF)

752 Laboratory And Office Building (L\&O Building)

771 Radioactive Scrap And Wasle Facility (ASWF)

775 ZPPR Workroom-Equipment Roorn

776 ZPPA Reactor Cell

785 Hol Fuel Examination Facility (HFEF)

797 Radicactive Sodium Storage Facility (RSSA)

798 Radioactive Liquid Waste Treatment Facility (RLWTF)

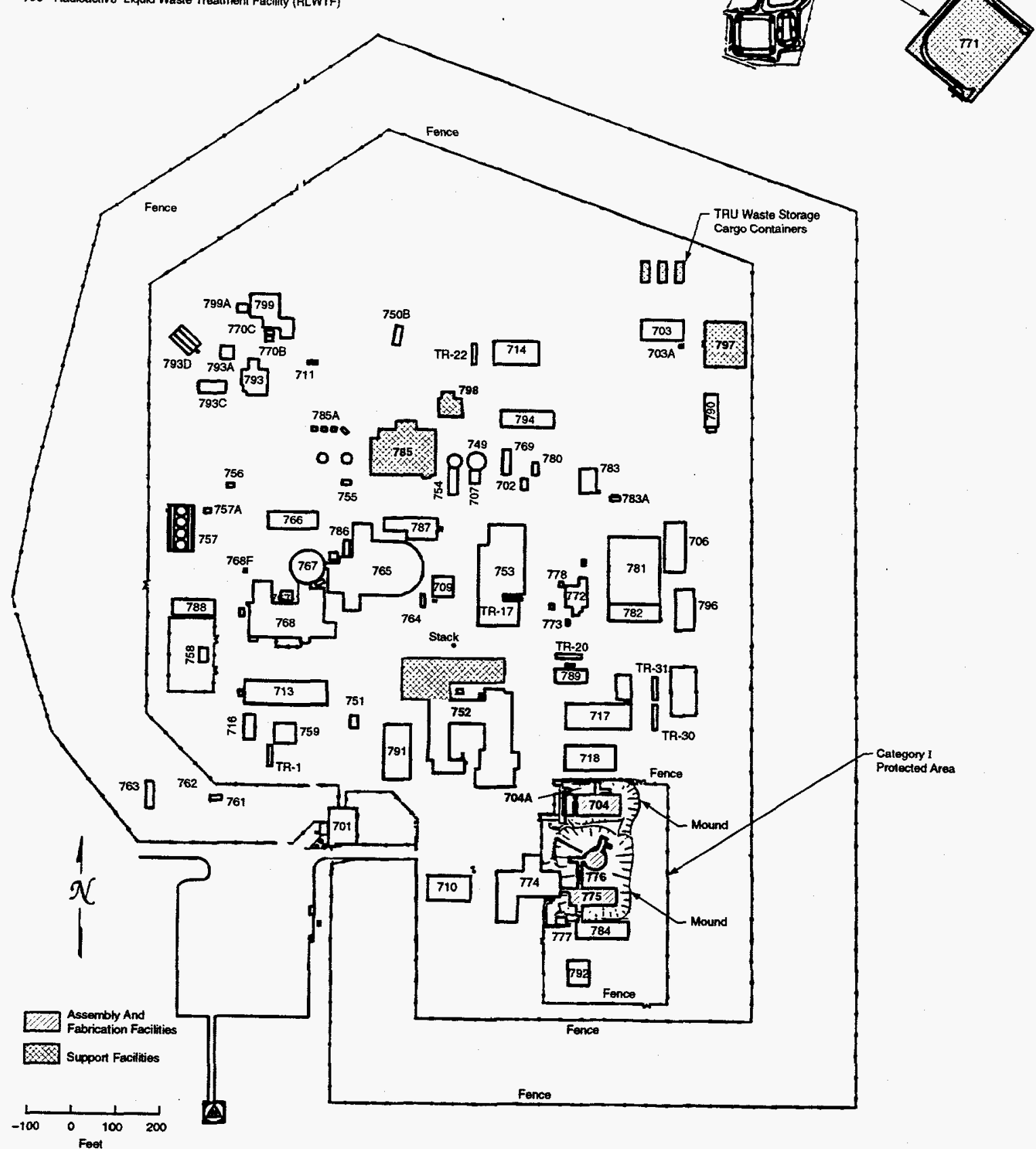

Fig. 4. ANL-W site map. 
Although these programs will be completed prior to the LTA mission, the monitoring systems developed would not interfere with the LTA program and could possibly be integrated in the LTA material and accountability program.

Two missions are currently under way in FASB. The first is the Reduced Enrichment Research Test Reactor (RERTR) Program, and the second is the Spent Fuel Demonstration Program.

The goal of the RERTR Program is to reduce the threat of nuclear proliferation by decreasing the worldwide availability of highly enriched uranium (HEU). This program is jointly funded by the U.S. State Department and DOE. A major facet of this program is the development of low-enrichment uranium (LEU) fuel to replace the HEU-based fuel currently used in many of the world's research reactors. These reactors represent an inventory of about one-half of the exported mass of U.S. origin HEU. Refueling these reactors with LEU will significantly reduce the threat of nuclear terrorism. The new LEU fuel will be based on high-density uranium alloys dispersed in an aluminum or magnesium matrix. No data exist on the performance of this type of fuel, and a substantial research program is under way at ANL-W to investigate this issue. This research program requires that we fabricate and irradiation test different uranium alloy and matrix configurations. This work is being performed in the West Room of FASB.

One of the waste form projects currently being carried out at ANL-W involves the production of a zeolite-glass ceramic waste form. The zeolite and glass are combined with the waste and are processed in a hot isostatic press (HIP). The zeolite is used to trap the waste into its lattice structure, and the glass is used to further increase the durability of waste-occluded zeolite. This system is composed of two separate glove boxes that are attached via a transfer chamber. There will be no radioactive material placed in this enclosure for this project. This work is also being performed in the West Room of FASB.

\subsubsection{Special Equipment or Structural Elements of the ZPPR/FMF/FASB Complex}

\subsubsection{FMF (Building 704)}

The manufacturing/vault area of FMF is $\sim 104 \mathrm{ft}$ long, $50 \mathrm{ft}$ wide, and $16 \mathrm{ft}$ high. It consists of an 18-in.-thick concrete floor slab, 14-in.-thick exterior walls, and a 9-in. thick roof slab over precast T-beams. The roof and walls are covered with $4 \mathrm{ft}$ of soil. The building was constructed in 1985-86 and was designed for a peak ground acceleration of $0.22 \mathrm{~g}$, which exceeds the current requirements for a Performance Category 3 facility. The FMF support wing is $\sim 50 \mathrm{ft}$ long, $19 \mathrm{ft}$ wide, and $24 \mathrm{ft}$ high. It has a 12-in. concrete floor slab, 12-in. masonry block walls, and 8-in. hollow core slabs with a 2-in. topping on the second floor and roof. The support wing was designed to 1982 Uniform Building Code (UBC) Zone 3 requirements using an importance factor of 1.5 .

\subsubsection{ZPPR vault/workroom (Building 775)}

The ZPPR vault/workroom is $\sim 110 \mathrm{ft}$ long, $42 \mathrm{ft}$ wide, and $14 \mathrm{ft}$ high. It consists of a 14-in. concrete floor slab, 12-in.-thick concrete walls, and a 7-in. concrete roof slab over precast T-beams. The roof and walls are covered with a minimum of $4 \mathrm{ft}$ of soil. The building was constructed in 1968, and in 1974 the north wall to roof connection was strengthened to allow the building to meet UBC Zone 3 seismic requirements.

\subsubsection{ZPPR reactor (Building 776)}

The reactor cell is a 50 -ft-diam circular room with an overall height of $\sim 60 \mathrm{ft}$. The floor and walls are constructed of reinforced concrete. The reactor cell roof is composed of layers of washed gravel and sand, supported by a catenary cable network of 1.875 -in. steel cables anchored in a $6 \mathrm{ft} 11$ in. wide by $4 \mathrm{ft} 6 \mathrm{in}$. deep concrete ring beam. The bottom of the reactor pit has a 7 -ft-thick concrete floor and 3-ft-thick walls. The design of the reactor cell was based on two criteria: (1) UBC Zone 2 seismic requirements, and (2) the ability to withstand a 75-psi internal cell pressure. The safety factor used on the roof catenary cable system was at least 2.5. 


\subsubsection{FASB (Building 787)}

FASB has approximate dimensions of $125 \mathrm{ft}$ long, $51 \mathrm{ft}$ wide, and $18 \mathrm{ft}$ high. It is constructed of 8-in.-thick masonry block walls and 18.5-in.-deep prestressed concrete roof members. It has a 6-in.-thick concrete floor slab. It was designed in 1970 in accordance with UBC Zone 3 seismic requirements.

\subsubsection{Security Features}

The ZPPR/FMF complex is within a common security area. ZPPR and FMF are both "hardened," Material Access Area (MAA) buildings currently approved for handling and storing Category I quantities of special nuclear materials (SNM). The complex is within a DOE-approved protected area (PA), contained within an approved property protection area (the main ANL-W site). The areas are surrounded by approved security fences and perimeter intrusion detection and alarm systems.

In addition to the installed facility monitoring and alarm systems, entrances are appropriately protected by metal detectors, SNM monitors, and double-barrier (airlock) doors. There is an approved Category I storage vault within each MAA.

The ANL-W security force was recently augmented to provide more on-site protection for SNM. Because ZPPR and FMF are Category I facilities, entry by foreign nationals and other noncleared personnel involved in inspection would be done by escort using existing administrative procedures. This is currently done routinely at these facilities.

The FASB security operations are controlled by the ANL-W Safeguards and Security Program. The FASB vault is constructed to meet DOE security standards. The vault is equipped with intrusion detection alarms. In the event of an unauthorized entry, DOE and ANL-W security forces will be alerted by the alarm systems. The security alarms are tested on a weekly schedule, and records of these tests are maintained by the ANL-W security force. In the event of an unscheduled alarm, an ANL-W security guard can respond as required by AECM 2405. The security force inspects the perimeter of the FASB vault during nonoperational periods. Access to the building is restricted by cipher locks, and access to the vault is restricted to SNM personnel by means of a combination-locked vault door. Access to the vault is controlled, and continuous surveillance is required. A detailed log of all vault activity is also maintained.

\subsubsection{Filtration Systems for the ZPPR/FMF/FASB Complex}

\subsubsection{FMF (Building 704)}

FMF has an operating HEPA-filtered, zone-controlled ventilation system, but it is not sufficient "as is" for plutonium powder. However, after the planned FMF upgrade, the ventilation system will be sufficient for this purpose.

Currently, a definitive design is in progress to upgrade FMF for use as a plutonium laboratory. The approach for containing plutonium at its source is two-pronged. First, the inlet to the glove box is HEPA filtered, and the exhaust from the glove box passes through a non-DOP testable HEPA filter that is located inside the box for simplified changeout. Then immediately outside the box, the exhaust is filtered at a Flanders DOP testable G-1 housing. Credit toward the double-HEPA-filtered requirement is not taken for either of these HEPA filters, and the system is filtered by the primary and secondary HEPA filter banks prior to exiting the facility through the stack. This approach provides protection to the ductwork, dampers, and blowers. All other penetrations into the glove box are also double-HEPA-filtered, once on the inside and again on the outside of the box. For example, an air utility line would be fitted with an easily replaceable in-line HEPA filter cartridge that would be bagged out of the glove box, and then another inline HEPA filter just outside of the bulkhead.

Based on the planned FMF plutonium laboratory modifications, the process exhaust-which consists primarily of glove box, fume hood, and equipment exhaust-will be isolated from the room exhaust past the second stage of DOP-testable HEPA filters. At that point, the room exhaust system and the process exhaust system combine into the facility exhaust and pass through the final bank of DOP-testable HEPA filters before exiting FMF through the stack. 
FMF has three pressure control zones. Zone I exhausts the primary boundary such as glove boxes, fume hoods, and furnaces. Zone II exhausts the process areas and vault. Zone III exhausts the support areas.

All potentially contaminated air is exhausted through a common stack. Continuous monitoring and a representative sampling capability will be provided on the FMF exhaust stack. The ventilation exhaust stack is located as far away from any air intake as is reasonably possible.

\subsubsection{ZPPR (Buildings 775 and 776)}

ZPPR has an operating HEPA-filtered, zone-controlled ventilation system. Upgrades would be required for the ZPPR ventilation system. The existing ZPPR exhaust ventilation system provides HEPA filtration to minimize the release of plutonium and other hazardous material through the exhaust path. The intake ventilation system would need to be provided with either HEPA filtration or fail-safe backflow prevention to minimize the release of plutonium and other hazardous material through the inlet path.

The ZPPR reactor cell exhaust is the room exhaust; currently, no process (glove boxes, fume hoods, etc.) exhaust system is required in this area of ZPPR.

ZPPR also has three pressure control zones. Zone I exhausts the primary boundary such as glove boxes, fume hoods, and furnaces. Zone II exhausts the process areas and vault. Zone III exhausts the support areas.

Air-cleaning devices would be located as close to the source of contamination as practicable to avoid the unnecessary spreading of the contamination into ductwork, dampers, piping, valves, pumps, or other process areas. This includes the filtration of glove box exhaust air, which would pass through a roughing inside the box and then a Flanders, DOP-testable G-1 HEPA housing immediately beyond the exhaust point prior to the exhaust air entering a plenum. This filter would not be counted as a formal HEPA stage; however, it would be tested prior to installation and is DOP-testable. The HEPA filters downstream of the glove box would be readily accessible for filter changeout and testable. Internally removed HEPA filters would be utilized rather than push-through filter changeout systems.

All equipment and systems would need to be designed such that the failure of a single component would not result in an unacceptable radiological consequence.

The secondary confinement is currently designed for pressures that are consistent with the criteria for the ventilation system. The secondary confinement area is designed to be at a positive air pressure with respect to the primary confinement areas and at negative pressure with respect to the outside environment and adjacent building areas that are not primary or secondary barriers.

The portion of the ventilation system that is an integral part of the critical area would be designed to withstand design-basis accidents so that it will remain intact and continue to act as a confinement system.

All movement of personnel, material, and equipment between the process area and the uncontrolled area would be through a controlled area or an air lock.

Three negative pressure zones exist within ZPPR. The first, the process confinement system, serves the spaces within the glove boxes, transfer ports, process ovens, and other spaces that may contain plutonium during the course of normal operations. The second zone serves the process areas and the vault area. The controlled areas that are contiguous to process areas and the vault that are potentially free of contamination constitute the third zone.

The existing ZPPR exhaust filter system consists of a minimum of two DOP-testable HEPA filters in series for room air. A new system, consisting of one roughing HEPA filter followed by three DOP-testable HEPA filters in series, for glove box exhaust air would be installed.

The process exhaust system for glove boxes would need to be isolated from the exhaust system for room air until the process exhaust has passed through two DOP-testable HEPA filters in series.

All potentially contaminated air is exhausted through a common stack. Continuous monitoring and a representative sampling capability would need to be provided on the ZPPR exhaust stack. The ventilation exhaust stack is located as far away from any air intake as is reasonably possible.

\subsubsection{FASB (Building 787)}

FASB has an operating HEPA-filtered, zone-controlled ventilation system. Upgrades would be required for the FASB ventilation system. The existing FASB exhaust ventilation system provides HEPA 
filtration to minimize the release of plutonium and other hazardous material through the exhaust path. The intake ventilation system would need to be provided with either HEPA filtration or fail-safe backflow prevention to minimize the release of plutonium and other hazardous material through the inlet path.

FASB has three pressure control zones. Zone I exhausts the primary boundary such as glove boxes, fume hoods, and furnaces. Zone II exhausts the process areas and vault. Zone III exhausts the support areas.

Air-cleaning devices would be located as close to the source of contamination as practicable to avoid the unnecessary spreading of the contamination into ductwork, dampers, piping, valves, pumps, or other process areas. This includes the filtration of glove box exhaust air, which would pass through a roughing inside the box and then a Flanders, DOP-testable G-1 HEPA housing immediately beyond the exhaust point prior to the exhaust air entering a plenum. This filter would not be counted as a formal HEPA stage; however, it would be tested prior to installation arid is DOP-testable. The HEPA filters downstream of the glove box would be readily accessible for filter changeout and testable. Internally removed HEPA filters would be utilized rather than push through filter changeout systems.

All equipment and systems would need to be designed such that the failure of a single component would not result in an unacceptable radiological consequence.

The secondary confinement is currently designed for pressures that are consistent with the criteria for the ventilation system. The secondary confinement area is designed to be at a positive air pressure with respect to the primary confinement areas and at negative pressure with respect to the outside environment and adjacent building areas that are not primary or secondary barriers.

The existing FASB exhaust filter system consists of a minimum of two DOP-testable HEPA filters in series for room air. The process exhaust is not currently isolated from the room.

All potentially contaminated air is exhausted through a common stack. Continuous monitoring and a representative sampling capability would need to be provided on the FASB exhaust stack. The ventilation exhaust stack is located as far away from any air intake as is reasonably possible.

\subsubsection{Specific Space in the ZPPR/FMF Complex to be Allocated to the LTA Mission}

All the space in the ZPPR work area $\left(3614 \mathrm{ft}^{2}\right)$ is proposed for fuel manufacturing and storage, and the ZPPR reactor cell $\left(2086 \mathrm{ft}^{2}\right)$ is proposed for a high bay fuel assembly and inspection area. The space in FMF $\left(5218 \mathrm{ft}^{2}\right.$ ) would be for fuel storage and for International Atomic Energy Agency (IAEA) inspection.

The building descriptions provided above specifically refer to these spaces. An additional $42,672 \mathrm{ft}^{2}$ of floor space in "nonhardened" buildings in the ZPPR/FMF complex could be made available to support the LTA mission.

\subsubsection{Other ANL - W and INEEL Facilities That Could Support the LTA Mission}

The ANL-W site has extensive experience in analyzing, handling, storing, and shipping transuranic (TRU) waste, hazardous waste, alpha LLW, LLW, and mixed waste (MW).

A large ANL-W AL specializes in actinide samples and actinide-bearing materials characterization. The AL, which recently completed an extensive refurbishment, expansion, and upgrade, has a wide assortment of modern instruments in use.

The Waste Characterization Area (WCA) is an alpha containment glove box facility used for characterization of TRU and low-level contact-handled $(\mathrm{CH})$ radioactive waste and is a Resources Conservation and Recovery Act (RCRA) interim status storage facility. It is located in the ANL-W Hot Fuel Examination Facility, which currently provides support to WIPP waste characterization activities.

The Radioactive Scrap and Waste Facility (RSWF) located in the northeast corner of the ANL-W site is a 4-acre outdoor underground vault storage area for the storage of remote-handled $(\mathrm{RH})$ waste prior to its disposal elsewhere. RSWF is a State of Idaho RCRA-permitted storage facility. It is permitted to store RH LLW, mixed LLW, TRU waste, and TRU MW.

The Radioactive Sodium Storage Facility (RSSF) is located in an ANL-W controlled-access, outside asphalt pad. Eight cargo containers are staged in the area for MW storage. The RSSF is a RCRA-permitted storage facility used to store $\mathrm{CH}$ radioactive and heavy metal (HM) contaminated debris along with sodium. and sodium-potassium alloy MW. 
TRU waste storage cargo containers used to store CH TRU waste are staged in the northeast corner of ANL-W. Waste is stored in these locked containers prior to shipment to disposal facilities.

INEEL also has a fully functioning TRU waste management capability with a large inventory of TRU waste currently being stored and certified for disposal at WIPP. Processing facilities are being developed to prepare the waste for disposal.

An INEEL fire station is located at ANL-W, and all the INEEL support infrastructure is available to ANL-W.

\subsubsection{Facility Modifications}

Without definitive requirements, it is not possible to be quantitative about the modifications and upgrades that would be required for the LTA mission at the ZPPR/FMF complex. A new ventilation system would likely be required, but this would be true for almost any existing facility. Chapters 4,5 , and 6 provide data associated with this facility modification and with the effort to remove the support structures in ZPPR, which was discussed in Sect. 2.2.1.

Modifications are currently under way in the West Room of FASB for the previously described RERTR and waste form development programs. A wet pipe sprinkler system will be installed within 6 months in all areas of FASB with the exception of the vault. For this proposed program, the overhead hoist would need to be upgraded for higher load capacity, and fuel assembly storage racks would be installed in the vault. 


\section{PROCESS DESCRIPTIONS}

\subsection{PROCESS FLOW DIAGRAM}

A process block flow diagram is provided in Fig. 5. Assumptions for the process were given in Table 4. Figure 5 provides the total quantity of HM throughput that is anticipated at each step of the process for an entire year of operations after the facility reaches steady state.

To achieve a state of reliable operations for the new facility, cold startup and hot startup phases are anticipated to be necessary. Table 5 provides the anticipated material requirements for each phase of the startup and operations for the LA MOX fuel fabrication facility. The cold startup consists of using only depleted $\mathrm{UO}_{2}$ in the fuel fabrication process to develop acceptable processing steps.

Hot startup consists of using the final MOX fuel blend to determine that each processing step meets acceptable standards of fuel quality and repeatability. This phase of startup is anticipated to require at least 6 months.

\subsection{WASTE MANAGEMENT FLOW DIAGRAMS}

Figure 6(a) and $(b)$ are simplified flow diagrams that indicate how all forms of waste from the LA MOX fuel fabrication facility will be handled and disposed. These flow diagrams are generic examples of how waste will be handled for each site. Of course, each site will have some site-specific variations from the given flow diagrams, but for the purposes of this study the given material flow diagrams should be adequate.

For ANL-W, liquid LLW will be treated at the Radioactive Waste Management Complex (RWMC) at INEEL; solid LLW will then be disposed of by burial at RWMC; and TRU waste will be stored at RWMC while awaiting final disposal at WIPP. 


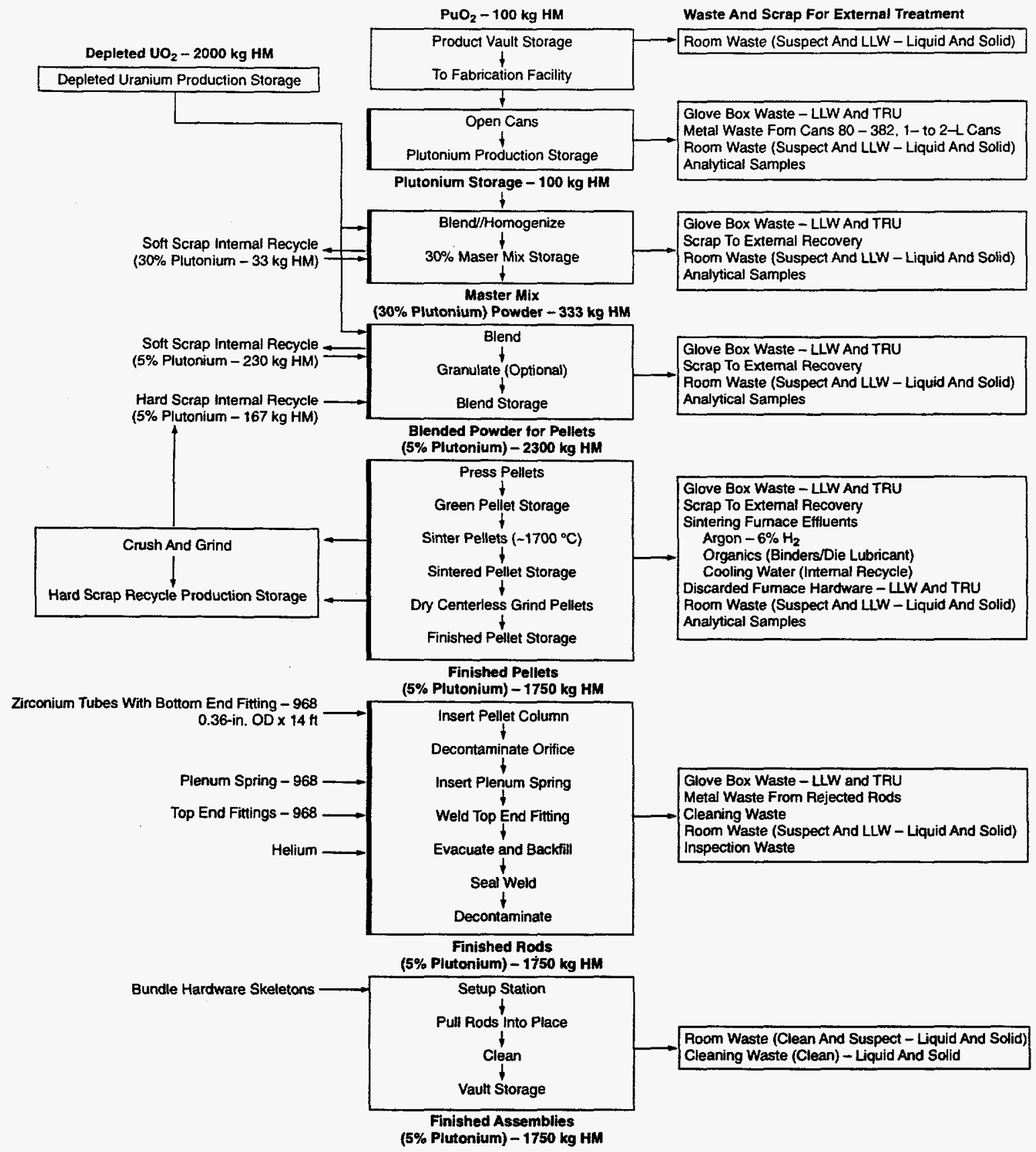

Note: 1. Heavy borders are glove box process operations.

2. A total of $20 \%$ of pellets will be recycled.

Fig. 5. LA MOX fuel flow sheet outline with annual throughputs. 
Table 5. LA MOX fuel fabrication requirements

\begin{tabular}{|c|c|c|c|c|c|c|c|c|c|c|}
\hline & \multirow[b]{2}{*}{ Units/bundle } & \multicolumn{2}{|c|}{ Product produced $^{a}$} & \multirow[b]{2}{*}{$\begin{array}{c}\text { Cold } \\
\text { startup }\end{array}$} & \multirow[b]{2}{*}{$\begin{array}{l}\text { Hot startup } \\
\text { (6 months) }\end{array}$} & \multicolumn{4}{|c|}{ Production capacity required ${ }^{a}$} & \multirow[b]{2}{*}{ Total } \\
\hline & & $\begin{array}{l}\text { Output- } \\
3 \text { years }\end{array}$ & $\begin{array}{l}\text { Output- } \\
1 \text { year }\end{array}$ & & & $\begin{array}{l}\text { Rejection } \\
\text { rate }^{b}\end{array}$ & $\begin{array}{l}\text { Capacityl } \\
3 \text { years }\end{array}$ & $\begin{array}{l}\text { Capacityl } \\
1 \text { year }\end{array}$ & $\begin{array}{l}\text { Capacity/d } \\
(200 \mathrm{~d} / \text { year })\end{array}$ & \\
\hline \multicolumn{11}{|l|}{ Base requirements and assumptions } \\
\hline Bundles/year [pressurized-water reactor $(\mathrm{PWR}) 17 \times 17$ ] & & 10 & 3 & & & $0 \%$ & 10 & 3.3 & & 10 \\
\hline Rods & 264 & 2,640 & 880 & 220 & 220 & $10 \%$ & 2,904 & 968 & 5 & 3,344 \\
\hline Pellets $(0.327$-in. diam $\times 0.4$ in. $\times 14 \mathrm{ft}$ ) & 110,880 & $1,108,800$ & 369,600 & 110,880 & 110,880 & $20 \%$ & $1,330,560$ & 443,520 & 2,218 & $1,552,320$ \\
\hline \multicolumn{11}{|l|}{ Plutonium and depleted uranium required } \\
\hline Plutonium ( $5 \%$ in depleted uranium), $\mathrm{kg} \mathrm{HM}^{C}$ & 25 & 250 & 83 & & 21 & $20 \%$ & 300 & 100 & 0.5 & 321 \\
\hline Depleted uranium, kg HM & 500 & 5,000 & 1,667 & 450 & 417 & $20 \%$ & 6,000 & 2,000 & 10 & 6,867 \\
\hline Total plutonium + depleted uranium, $\mathrm{kg} \mathrm{HM}{ }^{c}$ & 525 & 5,250 & 1,750 & 450 & 438 & $20 \%$ & 6,300 & 2,100 & 11 & 7,188 \\
\hline \multicolumn{11}{|l|}{ Scrap generation } \\
\hline Total scrap depleted uranium, kg HM & & & & 450 & & & & & & $450^{d}$ \\
\hline $\begin{array}{l}\text { Total scrap plutonium (mixed with depleted uranium), } \\
\text { kg HM }\end{array}$ & & & & & 13 & & 51 & 17 & 0.1 & $64^{d}$ \\
\hline $\begin{array}{l}\text { Total scrap depleted uranium (mixed with plutonium), } \\
\text { kg HM }\end{array}$ & & & & & 250 & & 1,000 & 333 & 2 & 1,250 \\
\hline \multicolumn{11}{|l|}{ Recycle and recovery scrap and waste quantities } \\
\hline $\begin{array}{l}\text { Recycled hard scrap }{ }^{e} \text { (mixed with depleted uranium), } \\
\text { kg HM }\end{array}$ & & & & & 6.25 & & 25 & 8 & & 31 \\
\hline $\begin{array}{l}\text { Recycled hard scrap depleted uranium (mixed with } \\
\text { plutonium), } \mathrm{kg} \mathrm{HM}\end{array}$ & & & & & 125 & & 500 & 167 & & 625 \\
\hline $\begin{array}{l}\text { Scrap plutonium to recovery (mixed with depleted } \\
\text { uranium), } \mathrm{kg} \mathrm{HM}\end{array}$ & & & & & 5 & & 21 & 7 & & 26 \\
\hline $\begin{array}{l}\text { Scrap depleted uranium to recovery (mixed with } \\
\text { plutonium), } \mathrm{kg} \mathrm{HM}\end{array}$ & & & & & 100 & & 400 & 133 & & 500 \\
\hline Waste plutonium (mixed with depleted uranium), $\mathrm{kg} \mathrm{HM}$ & & & & & 1.25 & & 6 & 2 & & 7 \\
\hline Waste depleted uranium (mixed with plutonium), kg HM & & & & & 25 & & 100 & 33 & & 125 \\
\hline \multicolumn{11}{|l|}{ Waste volumes } \\
\hline Volume of transuranic (TRU) waste generated, ${ }^{g} \mathrm{~m}^{3}$ & & & & & 10 & & 120 & 40 & 0.2 & 130 \\
\hline Volume of low-level waste (LLW) generated, $\mathrm{m}^{3}$ & & & & 10 & 10 & & 120 & 40 & 0.2 & 140 \\
\hline Volume of mixed LLW generated, $\mathrm{m}^{3}$ & & & & 0.4 & 0.4 & & 3 & 1 & & 4 \\
\hline Volume of liquid LLW generated, $\mathrm{L}$ & & & & 40,000 & 40,000 & & 480,000 & 160,000 & 800 & 560,000 \\
\hline Volume of liquid TRU generated, $\mathrm{L}$ & & & & & 50 & & 600 & 200 & 1 & 650 \\
\hline Volume of nonhazardous solid, $\mathrm{m}^{3}$ & & & & 650 & 650 & & 3,900 & 1,300 & & 5,200 \\
\hline Volume of nonhazardous sanitary liquid, L & & & & 800,000 & 800,000 & & $4,800,000$ & $1,600,000$ & & $6,400,000$ \\
\hline
\end{tabular}

${ }^{a}$ In the event LEU rods are used in place of MOX rods in the assembly, the amount of plutonium processed in the LA fuel fabrication facility will be reduced accordingly, as will the amount of waste generated.

${ }^{b}$ Assumed that pellets in rejected rods can be reused.

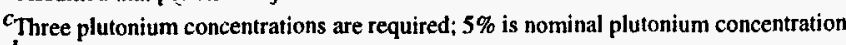

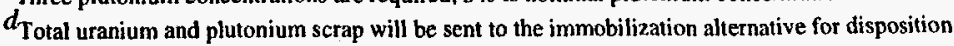

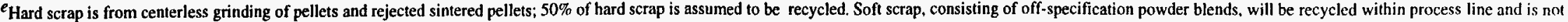
considered in this table.

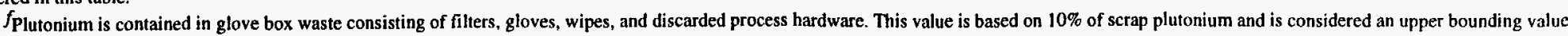

8 The volume of TRU waste includes mixed TRU waste: solid waste volumes were estimated in number of 200 -L drums generated. 
OANL-DWG 97-2856 EFG

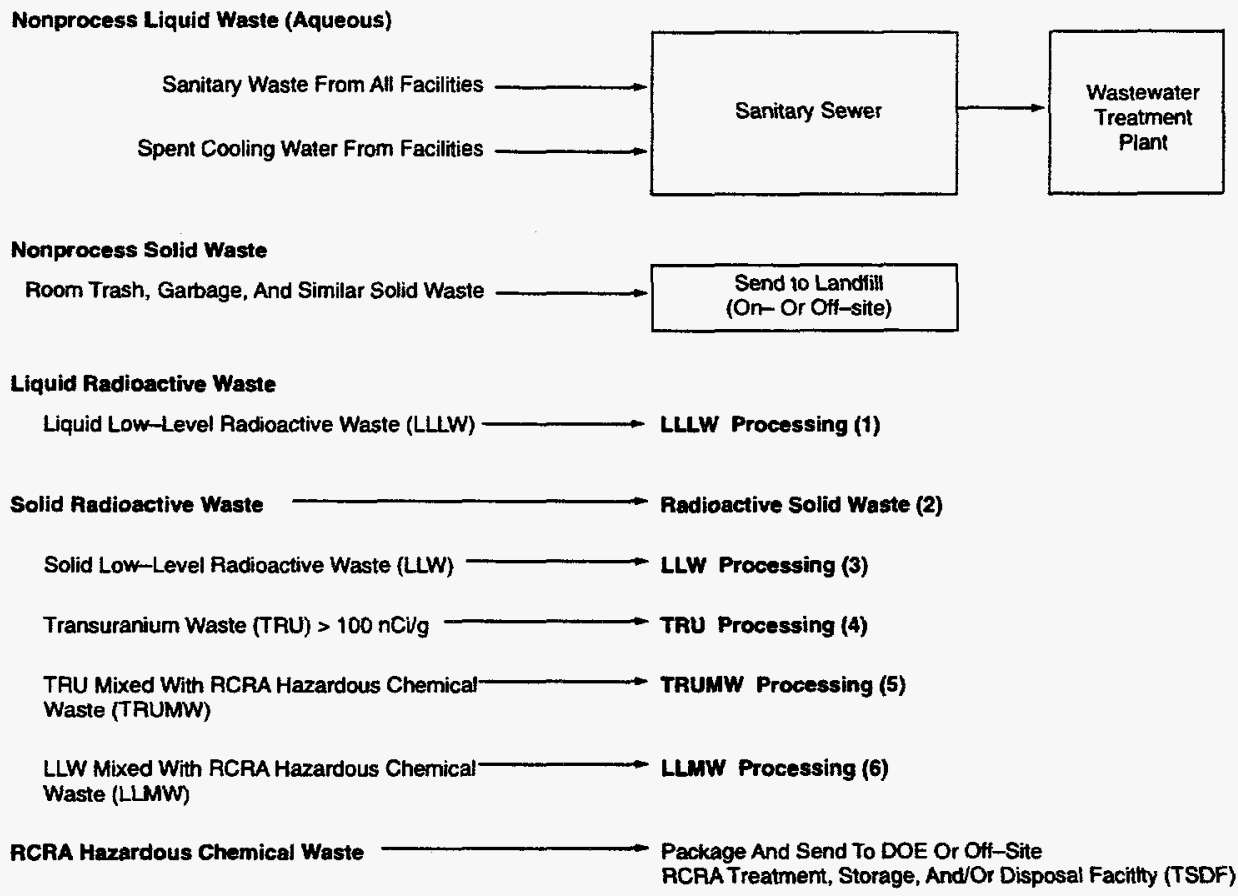

Fig. 6(a). Waste generated during LA MOX fuel fabrication facility operation. 
1. LLLW Processing

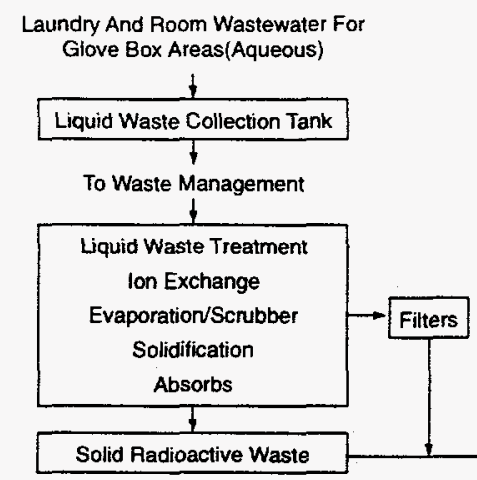

3. LLW Processing

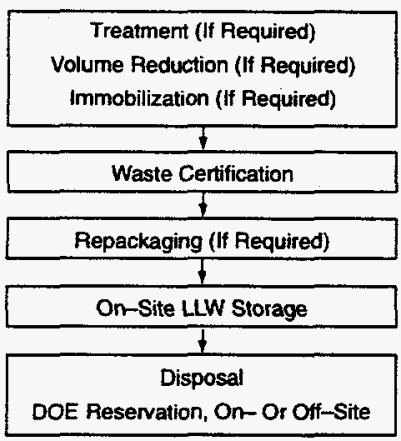

2. Solid Radioactive Waste

Glove Box And Some Room Waste

$$
\downarrow
$$

\begin{tabular}{|c|c|}
\hline Segregation By Generator & Hazardous Mixed Waste \\
\hline Compactable & 7 \\
\hline Noncompactable & Collection By Generatar \\
\hline Special Case Waste & 1 \\
\hline$I$ & Packaging By Generator \\
\hline Collection By Generator & $t$ \\
\hline 1 & Certification By Generator \\
\hline Packaging By Generator & 1 \\
\hline 1 & RCRA 90-d Siorage \\
\hline Certification By Generator & \\
\hline To Waste Management & To Waste Management \\
\hline & $\downarrow$ \\
\hline $\begin{array}{c}\text { Nondestructive Assay } \\
<100 \mathrm{nCi} / \mathrm{g} \text { To LLW Processing } \\
>100 \mathrm{nCi} / \mathrm{g} \text { To TRU Processing }\end{array}$ & $\begin{array}{c}\text { Nondestructive Assay } \\
<100 \mathrm{nCi} / \mathrm{g} \text { To LLMW Processing } \\
>100 \mathrm{nCi} / \mathrm{g} \text { To TRUMW Processing }\end{array}$ \\
\hline
\end{tabular}

4. Thu Solid Waste $>100$ nCig Processing

5. TRUMW Processing

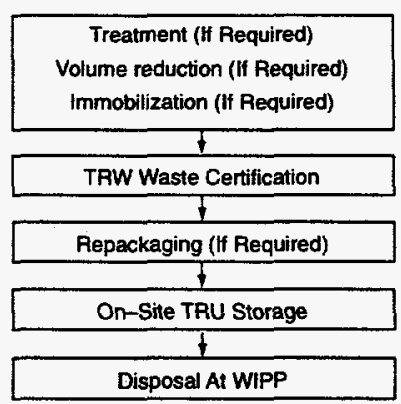

6. LLMW Processing

\begin{tabular}{|c|}
\hline RCRA Storage \\
\hline $\begin{array}{c}\text { Treatment (If Required) } \\
\text { Immobilization (If Required) }\end{array}$ \\
\hline Package \\
\hline \\
DCRAsposal \\
RCRAproved, On-Or Oft-Site \\
\hline
\end{tabular}

Fig. 6(b). Waste generated during LA MOX fuel fabrication facility operation. 
Page Intentionally Blank 


\section{RESOURCE NEEDS}

\subsection{CONSTRUCTION RESOURCE NEEDS}

Of the ANL-W facilities identified in Chap. 2 that could support this mission, only FMF and ZPPR would require modifications. These necessary modifications include demolition activities required to remove existing equipment utilized for previous missions, as well as ventilation and possible stack effluent monitoring modifications. The estimated resource needs for the modifications to both the FMF and ZPPR facilities are summarized in Table 6.

Table 6. Resource needs for modifications of FMF and ZPPR facilities

\begin{tabular}{|c|c|c|c|c|}
\hline Item No. & Resource identification & Quantity & Usage & Procurement \\
\hline \multicolumn{5}{|c|}{$F M F$} \\
\hline 1 & Ducting, SST & $1500 \mathrm{lb}$ & HVAC & Contractor \\
\hline 2 & Dampers, SST & 15 each & HVAC & Contractor \\
\hline 3 & Blowers & 2 each & HVAC & ANL-W \\
\hline 4 & HEPA filter housings & 1 each & HVAC & ANL-W \\
\hline 5 & HEPA filters & 12 each & HVAC & ANL-W \\
\hline 6 & Stack monitoring system & 1 each & Control & ANL-W \\
\hline 7 & Piping and fittings, SST & $100 \mathrm{ft}$ & HVAC & Contractor \\
\hline 8 & Piping and fittings, CS & $75 \mathrm{ft}$ & Utilities & Contractor \\
\hline 9 & Tubing and fittings, copper & $25 \mathrm{ft}$ & HVAC utilities & Contractor \\
\hline 10 & Valves, SST & 15 each & HVAC & Contractor \\
\hline 11 & Valves, CS & 5 each & Utilities & Contractor \\
\hline 12 & Valves, brass & 10 each & HVAC utilities & Contractor \\
\hline 13 & Structural, CS & $175 \mathrm{lb}$ & HVAC & Contractor \\
\hline 14 & Unistrut and components & $100 \mathrm{lb}$ & HVAC/utilities & Contractor \\
\hline 15 & Conduit & $200 \mathrm{ft}$ & Power/control & Contractor \\
\hline 16 & Wire & $600 \mathrm{ft}$ & Power/control & Contractor \\
\hline 17 & Junction boxes & 7 each & Power/control & Contractor \\
\hline 18 & Motor starters & 2 each & Pumps/blowers & Contractor \\
\hline 19 & Breakers & 5 each & Power & Contractor \\
\hline 20 & Power distribution panel & 1 each & Power & Contractor \\
\hline 21 & Pressure monitoring & 7 each & Control & Contractor \\
\hline 22 & Lumber & 800 bd-ft & D\&D & Contractor \\
\hline 23 & Polysheeting & $4000 \mathrm{ft}^{2}$ & D\&D & Contractor \\
\hline \multicolumn{5}{|c|}{$Z P P R$} \\
\hline 1 & Ducting, SST & $2500 \mathrm{lb}$ & HVAC & Contractor \\
\hline 2 & Dampers, SST & 20 each & HVAC & Contractor \\
\hline 3 & Blowers & 3 each & HVAC & ANL-W \\
\hline 4 & HEPA filter housings & 2 each & HVAC & ANL-W \\
\hline 5 & HEPA filters & 18 each & HVAC & ANL-W \\
\hline 6 & Stack monitoring system & 1 each & Control & ANL-W \\
\hline 7 & Piping and fittings, SST & $150 \mathrm{ft}$ & HVAC & Contractor \\
\hline 8 & Piping and fittings, CS & $75 \mathrm{ft}$ & Utilities & Contractor \\
\hline 9 & Tubing and fittings, copper & $50 \mathrm{ft}$ & HVAC utilities & Contractor \\
\hline 10 & Valves, SST & 25 each & HVAC & Contractor \\
\hline 11 & Valves, CS & 5 each & Utilities & Contractor \\
\hline
\end{tabular}


Table 6. (continued)

\begin{tabular}{clllc}
\hline Item No. & Resource identification & Quantity & Usage & Procurement \\
\hline 12 & Valves, brass & $15 \mathrm{each}$ & HVAC utilities & Contractor \\
13 & Structural, CS & $250 \mathrm{~b}$ & HVAC & Contractor \\
14 & Concrete & $7 \mathrm{yd} 3$ & ZPPR floor & Contractor \\
15 & Unistrut and components & $150 \mathrm{lb}$ & HVAC/utilities & Contractor \\
16 & Conduit & $300 \mathrm{ft}$ & Power/control & Contractor \\
17 & Wire & $900 \mathrm{ft}$ & Power/control & Contractor \\
18 & Junction boxes & $10 \mathrm{each}$ & Power/control & Contractor \\
19 & Motor starters & 2 each & Pumps/blowers & Contractor \\
20 & Breakers & 3 each & Power & Contractor \\
21 & Power distribution panel & 2 each & Power & Contractor \\
22 & Pressure monitoring & 10 each & Control & Contractor \\
23 & Lumber & $1000 \mathrm{bd}-\mathrm{ft}$ & D\&D & Contractor \\
24 & Polysheeting & $6000 \mathrm{ft}$ & D\&D & Contractor \\
\hline
\end{tabular}

These rough order-of-magnitude estimates were based on previous design work performed in FMF for the installation of a plutonium laboratory. This materials list is intended to fully support the facility modifications required for this mission in accordance with current local, state, and federal regulatory and code requirements. All materials would be procured from the contractor unless they are long lead items, in which case they would be furnished by ANL-W.

\subsection{OPERATIONAL RESOURCE NEEDS}

The initial scaling factor for resource requirements for the LA fabrication facility is based on a linear measure derived from the capacity of the MOX fuel fabrication facility. The annual quantity of surplus plutonium [3.5 metric tons (MT) plutonium (4.0 $\mathrm{MT} \mathrm{PuO}_{2}$ )] and the MOX fuel fabrication facility requirements were obtained from the LANL Response to the Surplus Plutonium Disposition Environmental Impact Statement Data Call for a Mixed Oxide Fuel Fabrication Facility Located at the Pantex Plant. ${ }^{2}$ The annual quantity requirement for uranium [88 MT HM (100 MT UO $\left.\mathrm{U}_{2}\right)$ ] was obtained from the Initial Data Report and Response to the Surplus Plutonium Disposition Environmental Impact Statement Data Call for the $\mathrm{UO}_{2}$ Supply. ${ }^{3}$

The annual plutonium and uranium capacity requirements and the scaling factors are calculated as follows:

1. LA fabrication facility plutonium capacity

Plutonium required for production $=250 \mathrm{~kg} \mathrm{HM}$ plutonium

Plutonium required including rejection rate of $20 \%=250 \mathrm{~kg} \mathrm{HM}$ plutonium $\times 120 \%=300 \mathrm{~kg} \mathrm{HM}$ plutonium ( $50 \mathrm{~kg} \mathrm{HM}$ to be recycled)

Annualized plutonium requirements $=(300 \mathrm{~kg} \mathrm{HM}$ plutonium $) / 3$ years $=100 \mathrm{~kg} \mathrm{HM}$ plutonium

Annualized MT HM plutonium capacity $=(100 \mathrm{~kg} \mathrm{HM}$ plutonium $) /(1000 \mathrm{~kg} / \mathrm{MT})=0.1 \mathrm{MT} \mathrm{HM}$ plutonium

2. LA fabrication facility uranium capacity

Uranium required for production $=5000 \mathrm{~kg} \mathrm{HM}$ uranium

Uranium required including rejection rate of $20 \%=5000 \mathrm{~kg} \mathrm{HM}$ uranium $\times 120 \%=6000 \mathrm{~kg} \mathrm{HM}$ uranium ( $1000 \mathrm{~kg} \mathrm{HM}$ to be recycled)

Annualized uranium requirements $=(6000 \mathrm{~kg} \mathrm{HM}$ uranium $) / 3$ years $=2000 \mathrm{~kg} \mathrm{HM}$ uranium Annualized MT HM uranium capacity $=(2000 \mathrm{~kg} \mathrm{HM}$ uranium $) /(1000 \mathrm{~kg} / \mathrm{MT})=2.0 \mathrm{MT}$ HM uranium

3. LA fabrication facility capacity 
Annual LA capacity $=(0.1$ plutonium +2.0 uranium $)$ MT HM $=2.1$ MT HM MOX

Annual mission surplus plutonium $=3.5 \mathrm{MT}$ HM plutonium

Annual uranium requirements for mission $\mathrm{MOX}$ at $5 \%$ plutonium $=66.5 \mathrm{MT}$ HM uranium

Annual MOX production $=(3.5$ plutonium +66.5 uranium $)$ MT HM MOX $=70$ MT HM MOX

4. Scaling factor $=(2.1 / 70) \mathrm{MT} H \mathrm{MMOX}=0.03 \%=3 \%$

This report assumes that $3 \%$ of the MOX fuel fabrication facility requirements is the initial base requirement of the LA fabrication facility. Resource requirements and contingencies in addition to $3 \%$ are noted separately for each resource. In situations where requirement scaling is not applicable, full calculations of resource requirements are provided. Resources needed for the LA fabrication facility are summarized in Table 7. (In the event LEU rods are used in place of some MOX rods, the resource needs will be reduced proportionately.)

\subsubsection{Utilities}

Utility connections at the sites being considered for the LA fabrication facility are currently installed and in use. For analysis purposes, it is not anticipated that additional connections will be required. Utility requirements beyond those necessary for maintenance of the building's present usage are based on those for the MOX fuel fabrication facility, scaled to $3 \%$, and then increased by a $200 \%$ contingency factor for bounding purposes. The original MOX requirements were developed from the NRC environmental report for the Westinghouse Recycle Fuels Plant (see Ref. 2, Appendix A) with a 200-MT MOX fabrication capacity. The annual requirements are calculated as

$$
24,000 \mathrm{MWh} \times(100 \mathrm{MT} / 200 \mathrm{MT}) \times 3 \% \times 200 \%=720 \mathrm{MWh} .
$$

The peak demand is based the MOX fabrication facility's peak demand of $<5 \mathrm{MW}(\mathrm{e})$ and is calculated as

$$
<5 \mathrm{MW}(\mathrm{e}) \times 1000 \mathrm{~kW}(\mathrm{e}) / \mathrm{MW}(\mathrm{e}) \times 3 \% \times 200 \%<300 \mathrm{~kW}(\mathrm{e})
$$

\subsubsection{Fuel Resources}

Fuel resource requirements for the LA fabrication facility are site dependent. Based on the MOX fabrication facility's generic fuel needs, it is assumed that the LA fabrication facility will require natural gas or coal for heating and electricity for sintering. Oil products or gasoline will be necessary for operation of two small generators and a small fleet of motorized vehicles.

Natural gas requirements for heating are calculated as

$$
920,000 \mathrm{~m}^{3} / \text { year } \times 3 \% \times 200 \% \text { contingency }=55,200 \mathrm{~m}^{3} / \text { year }
$$

Equivalent diesel oil requirements at $140,000 \mathrm{Btu} / \mathrm{gal}$ are

$$
\left(1,950,000 \mathrm{ft}^{3} \times 900 \mathrm{Btu} / \mathrm{ft}^{3}\right) /(140,000 \mathrm{Btu} / \mathrm{gal})=12,536 \mathrm{gal} \cong 13,000 \mathrm{gal}
$$

ANL-W will use diesel oil for heating.

Oil products in the form of diesel fuel are required for operation of emergency generators. Based on technical specifications and testing requirements for generator operability, ${ }^{4}$ each of two generators will operate $30 \mathrm{~h} /$ year. Testing is required for $1 \mathrm{~h}$ each month for verification of operation, $1 \mathrm{~h}$ twice a year for full-load and manual synchronization, and $24 \mathrm{~h}$ every 18 months to confirm capability for continuous operation. Assuming that peak capacity is $300 \mathrm{~kW}(\mathrm{e})$ and that approximately $50 \%$ of peak demand should be available for glove box ventilation, emergency lighting, and other required electrical support, two 
Table 7. Resource needs during operation of the LA fabrication facility

\begin{tabular}{|c|c|}
\hline Resource requirement & Annual average consumption \\
\hline \multicolumn{2}{|l|}{ Utilities } \\
\hline Electricity & $720 \mathrm{MWh}$ \\
\hline Peak demand & $<300 \mathrm{~kW}(\mathrm{e})$ \\
\hline \multicolumn{2}{|l|}{ Fuel } \\
\hline Diesel fuel (for heating) & $49,200 \mathrm{~L}(13,000$ gal $)$ \\
\hline Diesel fuel (for generator) & $4,600 \mathrm{~L}(1,215 \mathrm{gal})$ \\
\hline Gasoline (for vehicles) & $6,900 \mathrm{~L}(1,825 \mathrm{gal})$ \\
\hline \multicolumn{2}{|l|}{ Water } \\
\hline Groundwater & $1,600,000 \mathrm{~L}(411,000 \mathrm{gal})$ \\
\hline Peak demand & No peak requirements anticipated \\
\hline Surface water & None required for this process \\
\hline \multicolumn{2}{|c|}{ Process chemicals and compounds ${ }^{a}$} \\
\hline \multicolumn{2}{|c|}{ Gases } \\
\hline Argon & $16,000 \mathrm{~m}^{3}\left(565,000 \mathrm{ft}^{3}\right)$ \\
\hline Helium & $10 \mathrm{~m}^{3}\left(350 \mathrm{ft}^{3}\right)$ \\
\hline Hydrogen & $1,000 \mathrm{~m}^{3}\left(35,500 \mathrm{ft}^{3}\right)$ \\
\hline Nitrogen & $5,300 \mathrm{~m}^{3}\left(187,000 \mathrm{ft}^{3}\right)$ \\
\hline Oxygen & $5,000 \mathrm{~m}^{3}\left(174,000 \mathrm{ft}^{3}\right)$ \\
\hline \multicolumn{2}{|l|}{ Liquids } \\
\hline Hydrochloric acid $(\mathrm{HCl})$ & $0.5 \mathrm{~kg}(1 \mathrm{lb})$ \\
\hline Nitric acid $\left(\mathrm{HNO}_{3}\right)$ & $1 \mathrm{~kg}(2 \mathrm{lb})$ \\
\hline Polyethylene glycol & $20 \mathrm{~kg}(<45 \mathrm{lb})$ \\
\hline Sulfuric acid $\left(\mathrm{H}_{2} \mathrm{SO}_{4}\right)$ & $2 \mathrm{~kg}(5 \mathrm{lb})$ \\
\hline \multicolumn{2}{|l|}{ Solids, $\mathrm{kg}(\mathrm{lb})$} \\
\hline Sodium hydroxide $(\mathrm{NaOH})$ & $16 \mathrm{~kg}(34 \mathrm{lb})$ \\
\hline Sodium nitrate $\left(\mathrm{NaNO}_{3}\right)$ & $85 \mathrm{~kg}(<200 \mathrm{lb})$ \\
\hline Zinc stearate & $20 \mathrm{~kg}(<45 \mathrm{lb})$ \\
\hline \multicolumn{2}{|l|}{ Nonprocess chemicals } \\
\hline \multicolumn{2}{|l|}{ Liquids } \\
\hline Alcohol & $225 \mathrm{~L}(60 \mathrm{gal})$ \\
\hline Hydraulic fluid & $4.5 \mathrm{~kg}(10 \mathrm{lb})$ \\
\hline General cleaning fluids & $225 \mathrm{~L}(60 \mathrm{gal})$ \\
\hline \multicolumn{2}{|l|}{ Radioactive process materials } \\
\hline \multicolumn{2}{|l|}{ Plutonium dioxide $\left(\mathrm{PuO}_{2}\right)$} \\
\hline Hot startup & $23.6 \mathrm{~kg}(52 \mathrm{lb})$ \\
\hline Annually for 3 years & $113.5 \mathrm{~kg}(250 \mathrm{lb})$ \\
\hline \multicolumn{2}{|l|}{ Uranium dioxide $\left(\mathrm{UO}_{2}\right)$} \\
\hline Cold startup & $510 \mathrm{~kg}(1,125 \mathrm{lb})$ \\
\hline Hot startup & $475 \mathrm{~kg}(1,045 \mathrm{lb})$ \\
\hline Annually for 3 years & $2,270 \mathrm{~kg}(5,000 \mathrm{lb})$ \\
\hline
\end{tabular}

$a_{\text {Requirements for insignificant amounts will most likely be met from existing site }}$ inventory. 
$150-\mathrm{kW}$ capacity generators will be necessary at the LA fabrication facility. Based on a consumption rate of $38 \mathrm{~L} / \mathrm{h}(10 \mathrm{gal} / \mathrm{h})$, requirements for oil products are calculated as follows:

$$
38 \mathrm{~L} / \mathrm{h} \times 30 \mathrm{~h} / \text { year } \times 2 \text { generators } \times 200 \% \text { contingency }=4560 \mathrm{~L} / \text { year } \cong 4600 \mathrm{~L} / \text { year } .
$$

Because of the facility size and the potential distances between areas being used to support the LA mission, a distance of up to 2.5 miles $(4 \mathrm{~km})$ between the LA fabrication facility and other areas is assumed. An estimate of gasoline required for operation of motorized vehicle usage is based on requirements of 5 miles round-trip for 10 trips daily at $\sim 0.38 \mathrm{~L} / \mathrm{mile}(0.1 \mathrm{gal} / \mathrm{mile})$. The standard days of operation are calculated in Sect. 5.1 as $365 \mathrm{~d} /$ year. The fuel consumption for motorized vehicles at the LA. fabrication facility is estimated as

$$
10 \mathrm{trips} / \mathrm{d} \times 5 \mathrm{miles} / \text { trip } \times 0.38 \mathrm{~L} / \text { mile } \times 365 \mathrm{~d} / \text { year }=6935 \mathrm{~L} / \text { year } \cong 6900 \mathrm{~L} / \text { year } .
$$

The total requirement for oil products is $\sim 11,500 \mathrm{~L} /$ year $(3,040 \mathrm{gal} / \mathrm{year})$.

\subsubsection{Water}

Based on the MOX fuel fabrication facility's water requirement of $25 \mathrm{gal} / \mathrm{d}(95 \mathrm{~L} / \mathrm{d})$ per employee, 24 employees working $250 \mathrm{~d}$ at the LA fabrication facility on the first shift, and 12 employees performing shift work for $365 \mathrm{~d}$, the annual sanitary water resource usage is calculated as

$(25 \mathrm{gal} / \mathrm{d}) \times[(24 \mathrm{employees} \times 250 \mathrm{~d} /$ year $)+(12$ employees $\times 365 \mathrm{~d} /$ year $\times 2 \mathrm{shifts})$

$$
+(12 \text { employees } \times 115 \mathrm{~d} / \text { year })]=403,500 \mathrm{gal} / \mathrm{year},
$$

where calculations of the number of employees are in Sect. 5.1.

Nonsanitary water requirements are based on scaling the MOX fuel fabrication facility ${ }^{2}$ with a $100-\mathrm{MT}$ capacity to $10 \%$ of requirements. The $10 \%$ factor was used in lieu of $3 \%$ based on the nonlinear requirements for staffing between the MOX fuel fabrication facility and the LA fabrication facility. The usage is calculated as follows:

$$
191 \mathrm{gal} / \mathrm{d} \times 10 \% \times(365 \mathrm{~d} / \mathrm{year})=6972 \mathrm{gal} / \mathrm{year} .
$$

Total groundwater usage is rounded to $411,000 \mathrm{gal} /$ year $(1,600,000 \mathrm{~L} / \mathrm{year})$.

\subsubsection{Process and Nonprocess Chemicals and Compounds}

Process and nonprocess chemicals in gas, liquid, and solid form will be required in the operation of the LA fabrication facility. Those chemicals required in significant quantities are identified in Table 7. Most of the chemicals required will be available from existing site inventory.

It is assumed that the sintering furnace will have a purge rate of $30 \mathrm{~L} / \mathrm{min}$, requiring $\sim 94 \%$ argon and $6 \%$ hydrogen for operations. This number is derived as a function of the purge rates for large production furnaces that are typically on the order of $10 \mathrm{ft}^{3} / \mathrm{min}$. Assuming that the sintering furnace for the LA program will require one-tenth of the typical purge rate, a rate of $1 \mathrm{ft}^{3} / \mathrm{min}$ would be reasonable. There are $28.3 \mathrm{~L} / \mathrm{ft}^{3}$, which rounds up to $30 \mathrm{~L} / \mathrm{ft}^{3}$, resulting in a $30-\mathrm{L} / \mathrm{min}$ purge rate.

Because of requirement calculations for some chemicals resulting in minimal quantities, the amounts required have been rounded upward for bounding purposes. The quantities of process and nonprocess 
chemicals required in quantifiable amounts were calculated based on projected uses and requirements that follow.

Alcohol: for process and nonprocess cleaning purposes

$5 \mathrm{gal} / \mathrm{month} \times 12 \mathrm{months} /$ year $=60 \mathrm{gal} / \mathrm{year}$

Argon: required for sintering furnaces

$(30 \mathrm{~L} / \mathrm{min}) \times(525,600 \mathrm{~min} /$ year $) \times 0.001 \mathrm{~m}^{3} / \mathrm{L}=15,768 \mathrm{~m}^{3} /$ year $\cong 16,000 \mathrm{~m}^{3} /$ year

General cleaning fluids: for nonprocess cleaning purposes

$5 \mathrm{gal} / \mathrm{month} \times 12$ months $/$ year $=60 \mathrm{gal} /$ year

Helium: required as process gas

$0.2 \mathrm{~m}^{3} /$ week $\times 52$ weeks $/$ year $=10 \mathrm{~m}^{3} /$ year

Hydraulic fluid: lubricant

$0.2 \mathrm{lb} /$ week $\times 52$ weeks/year $\cong 10 \mathrm{lb} /$ year

Hydrochloric acid: required in service laboratory

$5 \mathrm{lb} \times 20 \%=1 \mathrm{lb} /$ year

Hydrogen: required in sintering furnaces

$(30 \mathrm{~L} / \mathrm{min}) \times(525,600 \mathrm{~min} /$ year $) \times 0.001 \mathrm{~m}^{3} / \mathrm{L} \times 6 \%=946 \mathrm{~m}^{3} /$ year $\cong 1000 \mathrm{~m}^{3} /$ year

Nitric acid: required in service laboratory

$8 \mathrm{lb} \times 20 \%=1.6 \mathrm{lb} /$ year $\cong 2 \mathrm{lb} /$ year

Nitrogen: required in glove boxes

$(1 \mathrm{~L} / \mathrm{min}) \times(525,600 \mathrm{~min} /$ year $) \times 0.001 \mathrm{~m}^{3} / \mathrm{L} \times 10$ glove boxes $=5256 \mathrm{~m}^{3} /$ year $\cong 5300 \mathrm{~m}^{3} /$ year

Oxygen: required for dry recycle process-assume $580 \mathrm{~h} /$ year dry recycle processing

$\left(5 \mathrm{ft}^{3} \mathrm{O}_{2} / \mathrm{min}\right) \times(60 \mathrm{~min} / \mathrm{h}) \times(680 \mathrm{~h} /$ year $)=\left(174,000 \mathrm{ft}^{3} \mathrm{O}_{2} /\right.$ year $) \cong 4927 \mathrm{~m}^{3} \cong 5000 \mathrm{~m}^{3} \mathrm{O}_{2} /$ year

Polyethylene glycol: required in blending process

$700 \mathrm{lb} \times 3 \% \times 200 \%=44 \mathrm{lb} /$ year $\cong 45 \mathrm{lb} /$ year

Sodium hydroxide: required in laboratory scrubber

$170 \mathrm{lb} \times 20 \%=34 \mathrm{lb} /$ year

Sodium nitrate: required in laboratory scrubber

$3100 \mathrm{lb} \times 3 \% \times 200 \% \equiv 186 \mathrm{lb} /$ year $\cong 200 \mathrm{lb} /$ year

Sulfuric acid: required in service laboratory

$17 \mathrm{lb} \times 20 \%=3.4 \mathrm{lb} /$ year $\cong 5 \mathrm{lb} /$ year

Zinc stearate: required in pellet pressing process

$670 \mathrm{lb} \times 3 \% \times 200 \%=40.2 \mathrm{lb} /$ year $\cong 45 \mathrm{lb} /$ year

\subsubsection{Radioactive Process Materials}

The radioactive process materials used at the LA fabrication facility are $\mathrm{PuO}_{2}$ and $\mathrm{UO}_{2}$. Based on the bounding case of $100 \mathrm{~g}$ plutonium per rod, 264 rods per assembly (full MOX), $5 \%$ plutonium for rods, and 
10 full-MOX assemblies produced over a 3-year period, $113.5 \mathrm{~kg}(250 \mathrm{lb})$ of $\mathrm{PuO}_{2}$ and $2270 \mathrm{~kg}(5000 \mathrm{lb})$ $\mathrm{UO}_{2}$ would be required annually. The calculations are provided in Sects. 4.2.5.1 and 4.2.5.2.

\subsubsection{Plutonium requirements}

The conversion factor for plutonium to $\mathrm{PuO}_{2}=\left(\mathrm{mol} \mathrm{wt} \mathrm{PuO}_{2}\right) /(\mathrm{mol}$ wt plutonium $)=271.0 /$ $239.0=1.1339$.

Plutonium required for 3-year LA mission $=250 \mathrm{~kg} \mathrm{HM}$ plutonium (Table 5)

Annual plutonium with rejection rate of $20 \%=250 \mathrm{~kg} \mathrm{HM}$ plutonium $\times 120 \% / 3$ years

$$
=100 \mathrm{~kg} \mathrm{HM} \text { plutonium } / \text { year }
$$

$100 \mathrm{~kg} \mathrm{HM}$ plutonium $\times 1.1339=113.39 \mathrm{~kg} \mathrm{PuO}_{2} \cong 113.5 \mathrm{~kg} \mathrm{PuO} 2 /$ year

The plutonium requirements for hot startup operations are

$$
(250 \mathrm{~kg} \mathrm{HM} \text { plutonium }) /(3 \text { years }) \times 25 \% \times 1.1339=23.6 \mathrm{~kg} \mathrm{PuO} 2
$$

Total plutonium requirements for the LA fabrication facility for the 3-year mission are $364 \mathrm{~kg} \mathrm{PuO}_{2}$.

\subsubsection{Uranium requirements}

The conversion factor for uranium to $\mathrm{UO}_{2}=\mathrm{mol} \mathrm{wt} \mathrm{UO}_{2} / \mathrm{mol} \mathrm{wt}$ uranium $=270.03 / 238.03=1.1344$.

Uranium required for 3-year $\mathrm{LA}$ mission $=5000 \mathrm{~kg} \mathrm{HM}$ uranium $($ Table 5)

Annual uranium with rejection rate of $20 \%=5000 \mathrm{~kg} \mathrm{HM}$ uranium $\times 120 \% / 3$ years

$$
=2000 \mathrm{~kg} \mathrm{HM} \text { uranium} / \text { year }
$$

$2000 \mathrm{~kg} \mathrm{HM}$ uranium $\times 1.1344=2268.8 \mathrm{~kg} \mathrm{UO} 2 \cong 2270 \mathrm{~kg} \mathrm{UO} 2 /$ year

The uranium requirements for cold and hot startup operations during the first year of production follow.

Hot: $(5000 \mathrm{~kg} \mathrm{HM}$ uranium $) /(3$ years $) \times 25 \% \times 1.1344=472.67 \mathrm{~kg} \mathrm{UO} \cong 475 \mathrm{~kg} \mathrm{UO} 2$

Cold: $(5000 \mathrm{~kg} \mathrm{HM}$ uranium $) /(3$ years $) \times 27 \% \times 1.1344=510.49 \mathrm{~kg} \mathrm{UO} \equiv 510 \mathrm{~kg} \mathrm{UO} 2$

Total uranium requirements for the LA fabrication facility for the 3-year mission are slightly less than $7,800 \mathrm{~kg}(17,200 \mathrm{lb}) \mathrm{UO}_{2}$. 
Page Intentionally Blank 


\section{EMPLOYMENT REQUIREMENTS}

\subsection{ANNUAL EMPLOYMENT REQUIREMENTS DURING OPERATION OF THE LA FABRICATION FACILITY}

Table 8 provides the annual number of employees by labor category, the number of shifts, the number of employees per shift, and the number of operating days per year for the LA fabrication facility. It is assumed that the facility will operate continuously with the primary work effort during standard business days of operation at the selected site. The standard days of operation were calculated as follows:

$$
(365 \mathrm{~d} / \text { year })-[(104 \text { weekend days })+(11 \text { holidays })]=250 \mathrm{~d} / \text { year } .
$$

The 11 holidays considered are New Year's Day, Martin Luther King Day, Good Friday, Memorial Day, Independence Day ( 2 days), Labor Day, Thanksgiving ( 2 days), and Christmas ( 2 days).

The number of employees in Table 8 was derived from a reduction in personnel required for the MOX fuel fabrication facility with consideration given for the nature of operations necessary to maintain 24-h performance. ${ }^{2}$ Twenty-four employees will be required on the standard operation shift. Twelve additional employees will be required on each of two alternate shifts, resulting in total staffing needs of 60 employees.

Many of these positions probably will be filled by existing employees at the site. This estimate is generic in nature, and some of the sites under consideration may require fewer employees based on existing infrastructure. For example, facilities with on-site plutonium processing facilities may require only a nominal increase in support personnel and management. Industrial support organizations (such as site superintendent, site security, emergency response, health services, and personnel support) and atmospheric and groundwater monitoring will be provided by the site operator because these facilities are currently being serviced by the site.

Based on the estimates for the MOX fuel fabrication facility, a personnel requirement was established if more than $80 \%$ effort of a full-time equivalent (FTE) was charged out to support the LA fabrication facility operation. ${ }^{2}$ Those efforts requiring less than $80 \%$ of an FTE were considered part of operations of the existing site: The assumptions used in consideration of staffing levels for the LA fabrication facility are given in Table 9.

\subsection{RADIATION DOSES (WHOLE BODY) TO INVOLVED WORKERS DURING MODIFICATION OF THE LA FABRICATION FACILITY}

Of the ANL-W facilities identified in Chap. 2 that could support this mission, only FMF and ZPPR would require modifications. These necessary modifications include demolition activities required to remove existing equipment utilized for previous missions, as well as ventilation and possible stack effluent monitoring modifications. The employment needs for the modifications in both the FMF and ZPPR facilities are summarized in Table 10.

\subsection{RADIATION DOSES (WHOLE BODY) TO INVOLVED WORKERS DURING OPERATION OF THE LA FABRICATION FACILITY}

The provided dose estimates to workers are based on those found in 10 Code of Federal Regulations (CFR) 835 and the administrative control level (ACL) found in DOE N 441.1. Fissile material processing for the LA program will be conducted at a DOE site and should be subject to DOE N 441.1, a DOE notice that establishes a maximum allowable dose of $2 \mathrm{rem} /$ year (see Table 11). ALARA will be the goal in all operations. The primary hazard in the LA program will be processing $\mathrm{PuO}_{2}$ powder and the possibility of inhalation of the $\mathrm{PuO}_{2}$ dust.

Estimated dose to radiation workers for handling 3013 cans during $\mathrm{PuO}_{2}$ powder homogenization operations and blending with $\mathrm{UO}_{2}$ powder will be below the ACL found in DOE N 441.1. 
Table 8. Annual employment requirements during operation of the LA fabrication facility

\begin{tabular}{lcc}
\hline Labor category $a$ & $\begin{array}{c}\text { Number of } \\
\text { employees on one } \\
\text { shift of } 250 \mathrm{~d} / \text { year }\end{array}$ & $\begin{array}{c}\text { Number of employees on } \\
\text { each of three alternate } \\
\text { shifts of } 365 \mathrm{~d} / \text { year }\end{array}$ \\
\hline Officials and managers & 1 & 0 \\
Professionals & 4 & 0 \\
Technicians & 10 & 7 \\
Office and clerical & 2 & 0 \\
Craft workers (skilled) & 2 & 1 \\
Operatives (semiskilled) & 2 & 2 \\
Service workers & 3 & $\frac{2}{12}$ \\
\hline Total & 24 & 12 \\
\hline
\end{tabular}

$a_{\text {All fractional manpower requirements are rounded up to whole numbers. }}$

$b_{\text {Two }} 365 \mathrm{~d} /$ year shifts and one $115 \mathrm{~d}$ /year shift.

Table 9. Assumptions used in consideration of staffing levels for the LA fabrication facility

1. The facility will be built on an existing DOE site with an estimate of $4500 \mathrm{ft}^{2}$ available space $\left(3000 \mathrm{ft}^{2}\right.$ for MOX rod processing, $1000 \mathrm{ft}^{2}$ for bundling activities, and $500 \mathrm{ft}^{2}$ for fuel bundle storage).

2. The site will have an existing infrastructure in place to accept the LA mission.

3. Personnel will be required to support a process capacity of $\sim 2$ MT HM per year.

4. Personnel involved in SNM operations must work in pairs and follow specific safety precautions detailed by the site.

5. Personnel must attend required site training. A staffing requirement for training purposes has been included in this estimate.

6. Space will be allocated for safe secure transports (SSTs) carrying plutonium and transportation for uranium so that loading can be accomplished on a follow-up operating shift if the transport arrives near or following the close of standard business.

7. As with the MOX fuel fabrication facility estimate, the staffing requirements assume that $\sim 20 \%$ of the employee's time will be taken through training, vacation, personal leave, or illness. Even though employees cannot necessarily transition from one position to another, a contingency was added to account for nonproductive time. 
Table 10. Employment needs during modification of the LA fabrication facility

\begin{tabular}{lcccc}
\hline \multicolumn{1}{c}{ Labor category } & $\begin{array}{c}\text { Number } \\
\text { of shifts }\end{array}$ & $\begin{array}{c}\text { Number of } \\
\text { employees per } \\
\text { shift }\end{array}$ & $\begin{array}{c}\text { Work period } \\
\text { in days }\end{array}$ & $\begin{array}{c}\text { Total number } \\
\text { of workdays }\end{array}$ \\
\hline Construction & & & & \\
Electricians & 1 & 2 & 87 & 174 \\
Plumbers/fitters & 1 & 2 & 87 & 174 \\
Sheetmetal workers & 1 & 2 & 130 & 260 \\
Sprinkler workers & 1 & 1 & 43 & 43 \\
Painters & 1 & 2 & 43 & 86 \\
Laborers & 1 & 3 & 130 & 390 \\
Foreman-subcontractor & 1 & 2 & 130 & 260 \\
Foreman-contractor & 1 & 1 & 130 & 130 \\
\hline
\end{tabular}

Table 11. Radiation doses (whole body) to involved workers during operation of the LA fabrication facility

Average maximum target annual dose to all involved workers at the 500 facility, mrem

Maximum allowable administrative dose limit, mrem 2000

Total number of involved workers 


\section{Page Intentionally Blank}




\section{WASTES, EMISSIONS, AND EXPOSURES}

\subsection{WASTE GENERATED DURING FACILITY MODIFICATION}

\subsubsection{Wastes}

No RCRA-regulated waste streams would be associated with the modification of either the FMF or the ZPPR facilities. Nonregulated waste streams would be associated with these modifications. The nonregulated waste streams would all be CH LLW. No TRU or MW streams would be associated with these modifications.

The following radionuclides could be present in the FMF CH LLW: ${ }^{234} \mathrm{U},{ }^{235} \mathrm{U},{ }^{236} \mathrm{U}$, and ${ }^{238} \mathrm{U}$. The following radionuclides could be present in the ZPPR CH LLW: ${ }^{238} \mathrm{Pu},{ }^{239} \mathrm{Pu},{ }^{240} \mathrm{Pu},{ }^{241} \mathrm{Pu},{ }^{241} \mathrm{Am}$, ${ }^{234} \mathrm{U},{ }^{235} \mathrm{U},{ }^{236} \mathrm{U}$, and ${ }^{238} \mathrm{U}$. However, the primary radionuclides would be from depleted uranium, and only low levels of contamination would be expected.

Packaging of $\mathrm{CH} L L W$ would be in $4 \mathrm{ft} \times 4 \mathrm{ft} \times 8 \mathrm{ft}$ boxes. The maximum weight of a loaded waste box is $2000 \mathrm{lb}$. The box itself weighs $530 \mathrm{lb}$, for a maximum of $1470 \mathrm{lb}$ of waste per box. It is estimated that the demolition work in FMF would require four full-weight boxes for a maximum of $5880 \mathrm{lb}$ of waste in a volume of $512 \mathrm{ft}^{3}$. It is estimated that the demolition work in ZPPR would require six full-weight boxes for a maximum of $8820 \mathrm{lb}$ of waste in a volume of $768 \mathrm{ft}^{3}$. Note that the ZPPR critical assembly structure was not included in the above waste volumes because it would be mothballed and stored in case of future use.

From Table 10, a total of 1517 workdays will be required to complete facility modifications at $25 \mathrm{gal} / \mathrm{d}$ per worker, a total of $37,925 \mathrm{gal}$ or $\sim 38,000 \mathrm{gal}$ of nonhazardous wastewater would be generated.

From Sect 4.1 it is estimated that a total of $750 \mathrm{ft}^{3}$ of nonhazardous solid waste would be generated to complete facility modifications.

\subsubsection{Emissions}

No radioactive emissions are anticipated as a result of these facility modifications. Only very small quantities of chemical emissions are expected from analytical operations during health physics surveys.

\subsubsection{Exposures}

No additional exposure doses are expected from either the demolition or construction activities above the low levels normally received during routine occupancy.

\subsection{WASTES GENERATED DURING OPERATION OF THE FACILITY}

Table 12 provides the annual volume, total estimated volume, description, and anticipated treatment method by waste category for liquids and solids anticipated during operation of the LA fabrication facility. Only very small quantities of chemical emissions are anticipated from analytical operations resulting from sampling.

A total of $0.4 \mathrm{mg} / \mathrm{year}$ of plutonium is estimated to be released to the air during the operation of the LA MOX facility. This plutonium release corresponds to a total activity of $94 \mu \mathrm{Ci} / \mathrm{year}$. The total plutonium release includes two contributions; $0.3 \mathrm{mg} / y e a r$ is expected to be released during normal operation of the plant and an additional $0.1 \mathrm{mg}$ /year during a one-time abnormal event (spilling the powder of one 3013-can).

The release during normal operation has been estimated from the releases reported in Ref. 2 for a 100-MT HM/year MOX plant with two lines. Reference 2 reports a release of $0.6 \mathrm{mg} / \mathrm{year}$ of plutonium. The LA MOX facility has only one line and a smaller capacity (about $2.5 \mathrm{MT} \mathrm{HM}$ /year). For conservatism, one-half of the releases of the large MOX plant (with two lines) has been estimated for the small LA MOX facility (with only one line), therefore the value of $0.3 \mathrm{mg} / \mathrm{year}$. No scaling consideration has been given to the much smaller capacity of the LA MOX facility (about 1/40 of the large MOX plant). 
Table 12. Estimated waste generated during operation of the LA fabrication facility ${ }^{a}$

\begin{tabular}{|c|c|c|c|c|c|c|c|}
\hline \multirow{2}{*}{$\begin{array}{c}\text { Waste } \\
\text { category }\end{array}$} & \multicolumn{2}{|c|}{ Annual volume } & \multicolumn{2}{|c|}{ Total volume } & \multirow{2}{*}{$\begin{array}{c}\text { Waste } \\
\text { description }\end{array}$} & \multirow{2}{*}{$\begin{array}{l}\text { Anticipated } \\
\text { treatment }\end{array}$} & \multirow{2}{*}{$\begin{array}{l}\text { Disposal } \\
\text { method }\end{array}$} \\
\hline & $\left(m^{3}\right.$ or $\left.L\right)$ & $\left(\mathrm{ft}^{3}\right.$ or gal) & $\left(m^{3}\right.$ or $\left.L\right)$ & $\left(\mathrm{ft}^{3}{ }^{\text {or }} \mathrm{gal}\right)$ & & & \\
\hline TRU-solid $\left(\mathrm{m}^{3}\right.$ or $\left.\mathrm{ft}^{3}\right)$ & 40 & 1,413 & 130 & 4,591 & $\begin{array}{l}\text { Glove box gloves } \\
\text { Bag-in plastic } \\
\text { Empty bottles } \\
\text { Filters } \\
\text { Scrapped equipment items } \\
\text { Furnace hardware } \\
\text { Wipes } \\
\text { Metal cans } \\
\text { Metallography waste }\end{array}$ & Compaction & $\begin{array}{l}\text { Off-site at Waste Isolation Pilot } \\
\text { Plant (WIPP) }\end{array}$ \\
\hline TRU-mixed $\left(\mathrm{m}^{3} \text { or } \mathrm{ft}^{3}\right)^{b}$ & $<1$ & $<35$ & $<1$ & $<35$ & $\begin{array}{l}\text { Organics from sintering } \\
\text { Sludges from liquids } \\
\text { Analytical waste }\end{array}$ & $\begin{array}{l}\text { From liquid treatment } \\
\text { absorption to TRU solid }\end{array}$ & Off-site at WIPP \\
\hline TRU_liquids (L or gal) & 200 & 53 & 650 & 172 & $\begin{array}{l}\text { Sludges from liquids } \\
\text { Analytical waste } \\
\text { Metallography waste }\end{array}$ & $\begin{array}{l}\text { Absorption to TRU solid } \\
\text { or liquid LLW }\end{array}$ & As solid off-site at WIPP \\
\hline $\mathrm{LLW}$-solid $\left(\mathrm{m}^{3}\right.$ or $\left.\mathrm{ft}^{3}\right)$ & 40 & 1,413 & 140 & 4,944 & $\begin{array}{l}\text { Room trash } \\
\text { Blotter paper } \\
\text { Wipes } \\
\text { Mop heads } \\
\text { Gloves/shoe covers } \\
\text { Solidified sludges } \\
\text { Ion exchange resins } \\
\text { Discarded C-clothing } \\
\text { Metal cans and rods }\end{array}$ & $\begin{array}{l}\text { Incineration } \\
\text { Compaction } \\
\text { Solidification } \\
\text { Metal melting }\end{array}$ & DOE on- or off-site disposal \\
\hline$L L W-\operatorname{mixed}(\mathrm{L}$ or gal) & 1 & 0.3 & 4 & 1.1 & $\begin{array}{l}\text { Solvents from cleaning } \\
\text { Analytical waste } \\
\text { Sludges from liquids }\end{array}$ & $\begin{array}{l}\text { Incineration } \\
\text { Solidification }\end{array}$ & $\begin{array}{l}\text { RCRA-approved disposal } \\
\text { DOE on- or off-site } \\
\text { Commercial off-site }\end{array}$ \\
\hline LLW-liquid (L or gal) & 160,000 & 42,267 & 560,000 & 147,935 & $\begin{array}{l}\text { Decontaminated wastewater } \\
\text { Laundry wastewater } \\
\text { Analytical wastewater }\end{array}$ & $\begin{array}{l}\text { Ion exchange } \\
\text { Evaporation/ } \\
\text { scrubber } \\
\text { Solidification }\end{array}$ & $\begin{array}{l}\text { Evaporation } \\
\text { NPDES }^{c} \text { permitted discharge }\end{array}$ \\
\hline Hazardous (L or gal) & 1.5 & 0.4 & 4 & & Process ends & Recycle & \\
\hline Nonhazardous-liquid (L or gal) & $1,600,000$ & 411,000 & $6,400,000$ & $1,644,000$ & Sewage waste & Sewage treatment & NPDES permitted discharge \\
\hline
\end{tabular}

${ }^{a}$ Base numbers were generated in metric system to two significant figures; English units are conversions using factors provided in data call.

${ }^{b}$ The volume of TRU-mixed waste is a portion of TRU solid waste volume; mixed TRU waste is likely to come from sludges from wastewater treatment.

$c_{\text {NPDES }}=$ National Pollutant Discharge Elimination System.

Note: Estimates are based on historical experience from other programs and current programs. 
The release during the abnormal event has been calculated by dropping one 3013 can containing $4.5 \mathrm{~kg}$ of plutonium. From Ref. 5 (Table 4-13) the following factors were selected:

- $\operatorname{ARF}$ (airborne release fraction) $=3.3 \times 10^{-3}$

- $\mathrm{RF}$ (respirable factor) $=0.62$

Also the efficiency of the HEPA filters in the glove box has been assumed to be $99.9 \%$ (equivalent to a release factor of $10^{-3}$ ) and the efficiency of the building HEPA filters as $99 \%$ (equivalent to a release factor of $10^{-2}$ ). Overall, the air emission for this event is

$$
4500 \mathrm{~g} \times 3.3 \times 10^{-3} \times 0.62 \times 10^{-3} \times 10^{-2}=0.092 \mathrm{mg} / \text { year } \cong 0.1 \mathrm{mg} / \text { year }
$$

Air emissions will result from the burning of diesel oil for building heat, but no more than would be expected if this activity did not occupy buildings at ANL. 
Page Intentionally Blank 


\section{ACCIDENT ANALYSIS}

\subsection{INTRODUCTION}

The LA fabrication process represents a very small scale process replication of the large 100-MT/year MOX fuel fabrication facility. The LA assembly fabrication will likely take place in an existing building complex. The process is envisioned to consist of a number (10-20) of glove boxes along with several hoppers, a press, a furnace, and a rod/bundle assembly area. The process can be done in a single large room, but it may also be done using several rooms (or buildings) with the material at the end stage of certain steps involving transportation and/or storage at another building. A generalized approach was taken because these specifics were unknown. Section 7.2 describes the accident analysis approach and mitigating design features that are assumed to be available. Section 7.3 describes the events that were selected for EIS evaluation and the estimated source terms that were chosen for all sites. These source terms are characterized here as "evaluation basis" because the facilities already exist and may have other design basis accidents that may or may not be similar to these accidents. Chemical source terms for the facility are discussed in Sect. 7.4. Site-specific aspects are discussed in Sect. 7.5.

\subsection{GENERAL APPROACH AND GENERIC DESIGN ASSUMPTIONS}

\subsubsection{Accident Analysis Approach}

In Ref. 2, a preliminary hazards analysis (PHA) was referenced for a 100-MT/year MOX fuel fabrication plant. This analysis identified 32 accidents which resulted from a variety of events. Specific events for the design-basis and beyond-design basis accidents were then selected from the hazard analysis to be further analyzed in the EIS. In that analysis, four design basis accidents and two beyond-design basis accidents were selected.

Several accident scenarios can be postulated for processing facilities, and many do not result in a source term that leaves the building. The objective of this accident analysis is to examine the frequency and estimated source terms of several events that are expected to result in a significant release from the building. Ventilation system design assumptions such as the use of HEPA filters that affect the leak-path factor are discussed in the next section. Using the methodology in Ref. 5, source terms are derived based on the combination of the material at risk, damage ratio, release fractions, respirable fractions, and the building leak-path factor.

The many unknowns and options associated with the LA fabrication plant did not warrant the performance of a building-/process-specific PHA for the LA facility. Currently, several different proposed fuel fabrication processes are combined with five sites. Knowledge concerning the PHA in Ref. 2 was combined with a knowledge of what the LA plant would generally be expected to look like. These aspects, along with a conservative estimate of the expected material flows of the plant, were used to select conservative accident source terms for the LA EIS analysis. Even though the scale of the LA plant is much smaller, it is thought that the LA facility will have many of the same accident initiators. Selected accident scenarios and the materials at risk were combined with bounding airborne release fractions and respirable fractions from DOE HDBK-3010-94 (Ref. 5) to derive conservative source terms.

With respect to estimated frequencies, the same approach that was taken in Ref. 2 is used. Frequency categories of anticipated $\left(10^{-1}\right.$ /year to $10^{-2}$ /year), unlikely $\left(10^{-2} /\right.$ year to $10^{-4} /$ year $)$, extremely unlikely $\left(10^{-4} /\right.$ year to $10^{-6} /$ year $)$, and beyond the evaluation basis $\left(<10^{-6} /\right.$ year for most events) were usually assigned in this assessment.

No attempt was made to quantify all of the site-specific features that affect the accident analysis. Rather, a generic set (six events are evaluated) of source term magnitudes was used at each site. This set of source terms was derived based on a specified plant process and some general assumptions regarding facility mitigators. No claim is made that the accident source terms cited here bound or are bounded by the existing site-specific analysis. Some site specifics such as stack heights and seismic frequencies were deemed to be a necessary input. The site-specific characteristics used for this site are discussed in Sect. 7.5. 
The generic facility design assumptions that are made which are not site-specific are discussed in Sect. 7.2.2.

\subsubsection{Facility Design Assumptions}

\subsubsection{Plutonium isotopics and MOX fuel}

The isotopic compositions of the plutonium and various MOX blends are shown in Table 13. With respect to both the master mix and fuel blend, the uranium dominates (a minimum of $90 \%$ ) the weight percent of the mix. However, the radiological contribution of the low specific activities of the uranium isotopes ( $\sim 5$ orders of magnitude) are so low (as compared to the plutonium isotopes) that they are ignored in the calculation of the source terms. In the event LEU rods will be used in place of some MOX rods, the radiological contribution from the LEU rods will also be very low compared to the plutonium contribution. Therefore, the accident analyses only consider full MOX assemblies. The respective isotopic activities for the plutonium oxide powder and the MOX powder (conservatively assuming 10\% enrichment) or fuel are shown in this table. For each accident scenario, the appropriate $\left(\mathrm{PuO}_{2}\right.$, master mix, or fuel blend) isotopic ratios are applied to the quantities at risk to determine the material at risk. This number is then multiplied by the leak-path factor, damage ratio, airborne release fraction, and respirable fraction to determine the released source terms. The leak-path factor incorporates the assumption as to whether the release is filtered.

\subsubsection{Ventilation system}

A complete description of site-specific existing facility ventilation system specifics is beyond the scope of this section. However, in many process buildings, ventilation flows are maintained such that fresh air is taken through the cleanest radiological areas (such as adjacent offices) first. The air flow path is then drawn through the rooms where radiological work is performed. Most facility systems are designed such that glove boxes in these rooms are run at pressures lower than the room pressure to limit the spread of contamination in the event of glove box failure. Contamination would be drawn in to the glove box filter to limit contamination in the room. The exact facility specifics and credit for mitigating design features involved in accident situations will vary, depending on the facility selected and any facility modifications needed to support the LA mission. The intent of this section is to clearly describe the mitigators associated with the ventilation system that are credited in this analysis.

Generally, a number of filters and prefilters would exist in the release path for a typical processing building that supports plutonium processing. Usually one or more filters are at the ventilation outlet of the glove box. These filters are generally accessible in the room where the glove box is located. However, no credit in source term reduction was taken for these filters in this analysis. This approach was taken because arguments could be made that the events in question jeopardize the integrity of nearby filters. For the EIS purposes, this approach was deemed appropriate. However, this does not mean that in the safety analysis (which would be performed after the building has been selected) of various glove box designs, credit could never be taken for those (or other) filters. The decision of what equipment will be qualified (and credit assumed for in the various events) will be made during the subsequent safety review of the facility (e.g., after facility selection). This decision is beyond the scope of this EIS analysis because many facility specific aspects are not known at this stage of the analysis.

The glove box system may be served by a dedicated ventilation system that often ties into the overall system upstream of a series of HEPA filters. With respect to the analysis of events in which overall building confinement is maintained, credit (for the source term reduction) is taken for two serial HEPA filters that generally lie outside the building confinement. The efficiency is assumed to be $99.9 \%$ for the first filter. A HEPA filter at the factory is rated at $99.97 \%$, but when installed may test to $99.95 \%$. The facility may run with this for a while and allow some degradation in performance during the operating period. Thus, in practice, a $99.9 \%$ efficiency is judged to be appropriate for this filter (roughing filters and prefilters are ignored). A reduced efficiency of $99.0 \%$ is used for the second filter (resulting in a combined leak-path factor of $1 \times 10^{-5}$ ). These filters are considered in this analysis where confinement is assumed to be intact and to provide significant source term reduction. 
Table 13. Specific activities for process powders (source of isotopics-Ref. 2)

\begin{tabular}{lrlccc}
\hline Isotope $^{a}$ & $\begin{array}{c}\text { Weight } \\
\text { percent }\end{array}$ & $\begin{array}{c}\text { Specific activity } \\
(\mathrm{Ci} / \mathrm{g})^{b}\end{array}$ & $\begin{array}{c}\text { Activity in } \\
\mathrm{PuO}_{2} \text { mix } \\
(\mathrm{Ci} / \mathrm{g} \mathrm{mix})^{c}\end{array}$ & $\begin{array}{c}\text { Activity in 30\% } \mathrm{PuO}_{2} \\
\text { enriched MOX mix } \\
(\mathrm{Ci} / \mathrm{g} \text { mix })^{d}\end{array}$ & $\begin{array}{c}\text { Activity in 10\% } \mathrm{PuO}_{2} \\
\text { enriched MOX mix (Ci/g } \\
\text { mix })^{d}\end{array}$ \\
\hline${ }^{238} \mathrm{Pu}$ & 0.03 & $1.712 \times 10^{1}$ & $4.530 \times 10^{-3}$ & $1.359 \times 10^{-3}$ & $4.530 \times 10^{-4}$ \\
$239 \mathrm{Pu}$ & 92.44 & $6.204 \times 10^{-2}$ & $5.045 \times 10^{-2}$ & $1.514 \times 10^{-2}$ & $5.045 \times 10^{-3}$ \\
$240 \mathrm{Pu}$ & 6.47 & $2.270 \times 10^{-1}$ & $1.293 \times 10^{-2}$ & $3.879 \times 10^{-3}$ & $1.293 \times 10^{-3}$ \\
$241 \mathrm{Pu}$ & 0.05 & $1.030 \times 10^{2}$ & $4.542 \times 10^{-2}$ & $1.363 \times 10^{-2}$ & $4.542 \times 10^{-3}$ \\
${ }^{242} \mathrm{Pu}$ & 0.10 & $3.926 \times 10^{-3}$ & $3.463 \times 10^{-6}$ & $1.039 \times 10^{-6}$ & $3.463 \times 10^{-7}$ \\
${ }^{241} \mathrm{Am}$ & 0.90 & $3.428 \times 10^{0}$ & $2.721 \times 10^{-3}$ & $8.163 \times 10^{-3}$ & $2.721 \times 10^{-3}$ \\
\hline
\end{tabular}

$a_{\text {The activity of }}{ }^{235} \mathrm{U}$ and ${ }^{238} \mathrm{U}$ are ignored for all mixes because of their low specific activities as compared to the plutonium isotopes.

${ }^{b}$ Specific activities are taken from Table of Radioactive Isotopes by Browne and Firestone. ${ }^{6}$

${ }^{c}$ Based on $\mathrm{PuO}_{2}$ mix being $88.2 \%$ plutonium by weight.

$d_{30 \%}$ is master mix; $10 \%$ is a conservative estimate for fuel blend. 


\subsubsection{Process flows}

Table 14 shows the process inventories and material flows used for the accident analysis. The average plutonium enrichment is nominally taken to be $5 \%$ for the fuel. However, because some fuel blends could go higher, an upper bound of $10 \%$ plutonium enrichment was selected. Table 14 was generally constructed on that basis. A $30 \%$ master mix blend was also selected. Table 14 was not intended to rigidly define the fuel fabrication material process because a number of candidate processes (with different material balances) may be used in the facility. Because the purpose of this table is to provide materials at risk, a conservative estimate of the maximum amount of material at a process station or in interim storage at a certain location was made.

Table 14. Estimated maximum station inventories for LA fabrication plant ${ }^{a}$

\begin{tabular}{|c|c|c|c|c|}
\hline Location/material station & Quantity $(g)$ & $\mathrm{PuO}_{2}$ or MOX & Physical form & $\begin{array}{l}\text { Barriers to release } \\
\text { (to the room) }\end{array}$ \\
\hline Plutonium storage vault & 400,000 & $\mathrm{PuO}_{2}$ & Fine powder & Storage cans/vault \\
\hline $\begin{array}{l}\text { Plutonium oxide ( } 2 \text { cans in } \\
\text { process) }\end{array}$ & 10,000 & $\mathrm{PuO}_{2}$ & Fine powder & $3013 \mathrm{can}^{7}$ \\
\hline $\begin{array}{l}\text { Plutonium oxide loading } \\
\text { vessel }\end{array}$ & 16,000 & $\mathrm{PuO}_{2}$ & Fine powder & Steel vessel/glove box \\
\hline Master mix vessel & 53,000 & MOX ( $30 \%$ blend) & Fine powder & Steel vessel/glove box \\
\hline Master mix powder storage & 107,000 & MOX ( $30 \%$ blend) & Fine powder & $\begin{array}{l}\text { Interim storage } \\
\text { cans/glove box }\end{array}$ \\
\hline V-blender & 40,000 & MOX (10\% blend) & Fine powder & $\begin{array}{l}\text { Rotating steel } \\
\text { vessel/glove box }\end{array}$ \\
\hline MOX blend storage & 320,000 & MOX (10\% blend) & Fine powder & $\begin{array}{l}\text { Interim storage } \\
\text { cans/glove box }\end{array}$ \\
\hline MOX granulation area & 10,000 & MOX (10\% blend) & $\begin{array}{l}\text { Pressed/very } \\
\text { coarse powder }\end{array}$ & Machinery/glove box \\
\hline MOX pellet press & 1,000 & MOX (10\% blend) & $\begin{array}{l}\text { Pressed to } 0.6 \\
\text { theoretical } \\
\text { density (TD) }\end{array}$ & $\begin{array}{l}\text { Inside of press/glove } \\
\text { box }\end{array}$ \\
\hline $\begin{array}{l}\text { MOX green pellet storage (in } \\
\text { pellet press area) }\end{array}$ & 80,000 & MOX (10\% blend) & $\begin{array}{l}\text { Pressed to } 0.6 \\
\text { TD }\end{array}$ & $\begin{array}{l}\text { Interim storage } \\
\text { cans/glove box }\end{array}$ \\
\hline Pellet sintering furnace & 40,000 & MOX $(10 \%$ blend $)$ & $\begin{array}{l}\text { Green and } \\
\text { sintered }\end{array}$ & $\begin{array}{l}\text { Inside furnace/glove } \\
\text { box }\end{array}$ \\
\hline Sintered pellet storage & 160,000 & MOX (10\% blend) & Sintered pellets & $\begin{array}{l}\text { Interim storage } \\
\text { cans/glove box }\end{array}$ \\
\hline $\begin{array}{l}\text { Pellet grinding area/ground } \\
\text { sintered pellets }\end{array}$ & 10,000 & MOX (10\% blend) & $\begin{array}{l}\text { Grindings of } \\
\text { sintered pellets }\end{array}$ & Containers/glove box \\
\hline $\begin{array}{l}\text { Pellet grinding area/dust } \\
\text { control area }\end{array}$ & 100 & MOX (10\% blend) & Fine powder & Loose dust/glove box \\
\hline Pellet inspection & 4,000 & MOX (10\% blend) & Finished pellets & Trays/glove box \\
\hline $\begin{array}{l}\text { Fuel rod loading, inspection, } \\
\text { and storage }\end{array}$ & 20,000 & MOX (10\% blend) & Finished pellets & $\begin{array}{l}\text { About ten rods if } \\
\text { cladded }\end{array}$ \\
\hline $\begin{array}{l}\text { Bundle assembly and storage } \\
\text { (end of fabrication) }\end{array}$ & $7,200,000$ & $\begin{array}{l}\text { MOX (5\% average } \\
\text { blend) }\end{array}$ & Finished pellets & $\begin{array}{l}\text { Cladded in ten } \\
\text { bundles }\end{array}$ \\
\hline Scrap recovery area & 10,000 & $\mathrm{MOX}$ and $\mathrm{PuO}_{2}$ & $\begin{array}{l}\text { Mostly green and } \\
\text { sintered pellets }\end{array}$ & Few dispersibles \\
\hline
\end{tabular}

$a_{\mathrm{No}}$ more than $32 \mathrm{~kg}$ of $\mathrm{PuO}_{2}$ (a batch) is used in the process line.

Source: Ref. 7. 
It is important to remember that with respect to assumed process flows, no more than $32 \mathrm{~kg}$ of plutonium oxide is ever assumed to be in the process line between the plutonium oxide vessel and the fuel rod loading step. As a result, no more than $32 \mathrm{~kg}$ of plutonium oxide (which is about $28 \mathrm{~kg}$ of pure plutonium) would be at risk in the process line, except for events that involve the vault (which is involved in beyond-evaluation basis events). The $32 \mathrm{~kg}$ of oxide does not include the two cans containing $5 \mathrm{~kg}$ of pure plutonium oxide that are assumed to be in process between the vault and the oxide loading vessel. Thus, a total of $42 \mathrm{~kg}$ of oxide in powder form has been considered in this analysis. Finished fuel rods are not considered because they are generally nondispersible as compared to powder. No effort has been made to model site-specific process flows and distinguish corresponding risk differences because there are so many process and facility unknowns at present. Rather, a generic (but thought to be generally conservative) process flow assumption has been made for all sites. Site-specific differences considered in the analysis are discussed in Sect. 7.5.

For most, if not all accident scenarios, materials at risk will be subjected to orders of magnitude multipliers in the calculation to determine the released source term. Thus, a high level of accuracy is not warranted at this stage of the analysis. Table 14 was used in combination with Ref. 5 and knowledge of the accident dynamics to obtain the source terms for the LA fabrication facility. In each accident scenario, a material at risk assumption is made at each station, depending on the event and energetics. Table 14 also lists the barriers to release that would be found inside the glove box. Generally, those materials that are inside interim storage cans were considered to be the most vulnerable to dispersion.

It is assumed that large amounts of $\mathrm{PuO}_{2}$ powder would be safely stored in appropriate containers 7 inside a vault or existing storage location. Considerable credit is taken for this vault (and/or the plutonium oxide containers), and it is assumed that the entire plutonium material feed requirement is in the vault at the start of the mission. It was conservatively assumed that $400 \mathrm{~kg}$ of oxide powder is in the vault at the start of the process. This inventory is held in 80 cans, each of which holds $5 \mathrm{~kg}$ of oxide powder $(4.4 \mathrm{~kg}$ of plutonium).

The overall layout of the facility is such that from 10-20 glove boxes are accommodated. The equipment is considered to be located in the same room, and generally, little credit is taken for segregation of the processes. Little credit is also taken for the glove boxes. The glove boxes are generally assumed to fail in the postulated events. This may or may not accurately portray the process line once it is designed (because glove boxes with a robust design may be used). However, this approach is thought to be conservative.

Finished fuel assemblies and clad rods were considered in this analysis but are thought to be generally nondispersible. Accidents that involve this inventory are thought to be bounded by the accidents involving the vault and the other in-process steps where dispersible powders are involved.

\subsection{SELECTED EVENTS FOR THE LA EIS ANALYSIS}

\subsubsection{Criticality Event}

\subsubsection{Discussion}

The prevention of criticality events is a major goal of the criticality safety program and is an important part of the overall conduct of operations for the facility. Within the nuclear processing industry, such prevention programs have successfully reduced the number of inadvertent criticalities over the years. The goal of the criticality safety program is to attempt (as much as is reasonably possible) to make the possibility of a criticality less than credible (generally accepted to be $<1 \times 10^{-6 / y e a r ~ f r e q u e n c y) . ~}$ Reference 8 establishes the DOE's nuclear criticality safety program requirements. Similarly, NRC also requires a criticality safety program, and those requirements are assumed to be implemented at the LA fabrication facility.

The risk impact associated with an inadvertent criticality event is highest with respect to workers located in the immediate vicinity (health impacts up to and including death could occur from prompt gamma and neutron doses). Collocated workers and the public would be affected to a lesser degree. The major dose pathways for these impacts are likely to be cloud shine (noble gases) and inhalation (mostly associated with the radioiodines). 
With respect to the LA fabrication plant, criticalities could be postulated in several areas (i.e., powder storage, the glove boxes involved in mixing, the furnace, and possibly the fuel rod storage area). The estimated frequencies associated with these events will vary depending on the controls in place, the number of operator movements, and the amount of fissile material present. A generic approach was taken with respect to the selection of the specifics of this event rather than selecting a criticality scenario associated with a specific operation in the LA fabrication.

\subsubsection{Source term}

The significant quantities of fissile materials in LA necessitate consideration of a criticality event. Because a limited number of rods are being made, a criticality event associated with a large array of fuel rods was not selected for this event. Because sources of moderation may be assumed to be either accidentally or inadvertently introduced into the glove boxes/equipment, the limiting fission yield for the facility was based on a scenario for a moderated powder or moderated solid criticality. In Ref. 9 (p. 6-24) dry powder and metal criticalities are quoted at a conservative yield of $1 \times 10^{7}$ fissions. A reference yield of $1 \times 1 b^{8}$ fissions is considered conservative for fully moderated and reflected solids. Therefore, a conservative selection of $1 \times 10^{18}$ fissions was made for the evaluation of this criticality event.

It is acknowledged that a dry criticality could potentially aerosolize surrounding plutonium and generate respirable particles. The amount of aerosolization is expected to be very small, and the presence of multiple filters would be an effective mitigator against the spread of plutonium out of the ventilation system. Thus, no plutonium was assumed to constitute the source term with respect to exposure of the collocated workers and the public that are outside of the building. Other events involving significant plutonium releases are discussed later.

With respect to release fractions associated with the fission products, it would be expected that a powder would have a surface area such that all noncondensible gases (such as the nobles) and all radioiodines would escape. However, if the criticality involved plutonium, which was in a relatively low surface area to volume ratio, the release fraction associated with the noble gases and radioiodines would be considerably less. In consideration of the present unknown specifics associated with this event, it was deemed conservative and appropriate to select the release fractions for both the nobles and the radioiodines as 1.0. Fission product yields from Table 6-9 of Ref. 5 (a plutonium solution of unknown isotopics for a reference yield of $1 \times 1 \mathrm{~b}^{9}$ fissions) were selected, and consideration of the selected yield of $1 \times 1 \mathrm{~B}^{8}$ fissions resulted in scaling the source terms.

The chosen source term specifics for the evaluation basis criticality event are shown in Table 15. As previously discussed, a conservative fission yield (moderated vs dry criticality) was combined with a conservative release fraction (for a powder vs moderated criticality). Thus, the source term in Table 15 is judged to be very conservative. The release height should be selected as the appropriate stack height for the facility where dose consequences are being calculated. The leak-path factor was taken as 1.0.

\subsubsection{Frequency estimate}

Criticalities have occurred considerably less frequently than in the earlier days of nuclear research, development, and operations. A number of these accidents are discussed in Ref. 10. None of these accidents are specifically associated with dry plutonium powder. However, several accidents involving dry metal, moderated metals, and fuel rods have occurred during the last 50 years. The fact that $30-40$ criticalities in the United States have historically (mostly in the 1940s, 1950s, and 1960s) occurred suggests that the accident spectrum analyzed for this facility should contain a criticality at a low estimated frequency. As was the case in Ref. 2, a frequency estimate of extremely unlikely $\left(1 \times 10^{-4}\right.$ to $1 \times 10^{-6} /$ year) is still judged to be appropriate for this event. However, the frequency of this event is judged to be somewhat less (perhaps 1 order of magnitude) than that at the large plant (100 MT/year vs 2 MT/year) because of the simplicity of the LA plant and the lower amounts of fissile material being handled. 
Table 15. Source term for the evaluation basis criticality event (stack release with a relatively short duration)

\begin{tabular}{ll}
\hline Isotope & $\begin{array}{c}\text { Released radioactivity } \\
(\mathrm{Ci})\end{array}$ \\
\hline${ }^{83} \mathrm{~m}_{\mathrm{Kr}}$ & $1.1 \times 10^{1}$ \\
$83 \mathrm{~m} \mathrm{Kr}$ & $7.1 \times 10$ \\
${ }^{85} \mathrm{Kr}$ & $8.1 \times 10^{-4}$ \\
$87_{\mathrm{Kr}}$ & $4.3 \times 10^{1}$ \\
${ }^{88} \mathrm{Kr}$ & $2.3 \times 10^{1}$ \\
${ }^{89} \mathrm{Kr}$ & $1.3 \times 10^{3}$ \\
$131 \mathrm{~m} \mathrm{Xe}$ & $1.0 \times 10^{-2}$ \\
$133 \mathrm{~m} \mathrm{Xe}$ & $2.2 \times 10^{-1}$ \\
$133 \mathrm{Xe}$ & $2.7 \times 10^{2}$ \\
$135 \mathrm{~m} \mathrm{Xe}$ & $3.3 \times 10^{2}$ \\
$135 \mathrm{Xe}$ & $4.1 \times 10^{1}$ \\
$137 \mathrm{Xe}$ & $4.9 \times 10^{3}$ \\
$138 \mathrm{Xe}$ & $1.1 \times 10^{3}$ \\
$131 \mathrm{I}$ & $1.1 \times 10$ \\
$132 \mathrm{I}$ & $1.2 \times 10^{2}$ \\
$133 \mathrm{I}$ & $1.6 \times 10^{1}$ \\
$134 \mathrm{I}$ & $4.3 \times 10^{2}$ \\
$135 \mathrm{I}$ & $4.5 \times 10^{1}$ \\
\hline
\end{tabular}

\subsubsection{Evaluation Basis Seismic Event}

\subsubsection{Discussion}

A seismic event appropriate for the facility's evaluation basis was selected. In this event, major portions of the process line glove boxes are assumed to be breached with the contents available for release. In such an event, the focus was on the dispersible powders that would be at the powder blending stations. The storage vault and receiving area are assumed to have suitable containers for plutonium oxide that will survive the earthquake ( 3013 cans with double containment). ${ }^{7}$ In-process material in glove boxes is, however, more vulnerable as are powder storage areas that may exist. Finished pellets and fuel rods are thought to be generally nondispersible even though they may escape the glove boxes. In this seismic event, the glove boxes are breached and assumed to fail based on a scenario of falling debris and equipment inside the room. The building confinement and ventilation system are assumed to remain intact, resulting in a filtered stack release.

\subsubsection{Source term}

Because the material in the vault is assumed to be in 3013 cans (which have double containment), no material was judged to be released from this area in this event. Table 16 shows the materials in process along with the release fractions and respirable fractions that were used. The total isotopic source term is shown summarized at the bottom for each plutonium isotope, as is the total amount of plutonium released. Because only $32 \mathrm{~kg}$ of plutonium oxide is allowed in a single batch, it was assumed that this batch was split in inventory between the master mix and fuel blend mix stations. This material was assumed to be in temporary storage cans at their respective stations. Another $10 \mathrm{~kg}$ of plutonium oxide in the form of powder is assumed to be at risk and open within the glove box. This material is from two cans that are taken out of the vault and prepared for loading (no credit for the 3013 can double containment). 
Table 16. Source term for the evaluation basis seismic event

\begin{tabular}{|c|c|c|c|c|c|c|c|c|c|c|c|c|}
\hline $\begin{array}{l}\text { Processing } \\
\text { station }\end{array}$ & $\begin{array}{l}\text { Material at } \\
\text { risk } \\
(\mathrm{g})\end{array}$ & $\begin{array}{l}\text { Physical } \\
\text { form }\end{array}$ & $\begin{array}{l}\text { Damage } \\
\text { ratio }\end{array}$ & $\begin{array}{l}\text { Airborne } \\
\text { release } \\
\text { fraction }\end{array}$ & $\begin{array}{l}\text { Respirable } \\
\text { fraction }\end{array}$ & $\begin{array}{l}\text { Leak-path } \\
\text { factor }\end{array}$ & ${ }^{238} \mathrm{Pu}$ & ${ }^{239} \mathrm{Pu}$ & $\begin{array}{l}{ }^{240} \mathrm{Pu} \\
\text { released }\end{array}$ & ${ }^{241} \mathrm{Pu}$ & $\begin{array}{l}{ }^{242} \mathrm{Pu} \\
\text { released }\end{array}$ & ${ }^{241} \mathrm{Am}$ \\
\hline $\begin{array}{l}\text { Plutonium oxide } \\
\text { ( } 2 \text { cans) }\end{array}$ & 10,000 & $\begin{array}{l}\text { Fine powder } \\
\mathrm{PuO}_{2}\end{array}$ & 1.00 & $1.00 \times 10^{-2}$ & 0.20 & $1.00 \times 10^{-5}$ & $9.06 \times 10^{-7}$ & $1.01 \times 10^{-5}$ & $2.59 \times 10^{-6}$ & $9.08 \times 10^{-6}$ & $6.93 \times 10^{-10}$ & $5.44 \times 10^{-6}$ \\
\hline $\begin{array}{l}\text { Master mix } \\
\text { powder storage }\end{array}$ & 53,000 & $\begin{array}{l}\text { Fine powder } \\
\text { MOX ( } 30 \% \\
\text { blend) }\end{array}$ & 1.00 & $1.00 \times 10^{-3}$ & 0.10 & $1.00 \times 10^{-5}$ & $7.20 \times 10^{-8}$ & $8.02 \times 10^{-7}$ & $2.06 \times 10^{-7}$ & $7.22 \times 10^{-7}$ & $5.51 \times 10^{-11}$ & $4.33 \times 10^{-7}$ \\
\hline $\begin{array}{l}\text { MOX blend } \\
\text { storage }\end{array}$ & 160,000 & $\begin{array}{l}\text { Fine powder } \\
\text { MOX }(10 \% \\
\text { blend) }\end{array}$ & 1.00 & $1.00 \times 10^{-3}$ & 0.10 & $1.00 \times 10^{-5}$ & $7.25 \times 10^{-8}$ & $8.07 \times 10^{-7}$ & $2.07 \times 10^{-7}$ & $7.27 \times 10^{-7}$ & $5.54 \times 10^{-11}$ & $4.35 \times 10^{-7}$ \\
\hline \multicolumn{7}{|c|}{$\begin{array}{l}\text { Total isotopic source term, } \mathrm{Ci} \\
\text { Total source term, } \mathrm{Pu} / \mathrm{Am} \text { mix, } \mathrm{g}\end{array}$} & $1.05 \times 10^{-6}$ & $\begin{array}{l}1.17 \times 10^{-5} \\
2.0454 \times 10^{-4}\end{array}$ & $3.00 \times 10^{-6}$ & $1.05 \times 10^{-5}$ & $8.03 \times 10^{-10}$ & $6.31 \times 10^{-6}$ \\
\hline
\end{tabular}


In a seismic event, powders in various pieces of equipment will be subjected to many different damage ratios and release fractions. For the pure oxide powder at the feed station, the entire amount was conservatively subjected to a release fraction corresponding to debris falling into powder (no credit for the two open cans, utilizing a $1 \times 10^{2}$ airborne release fraction and a 0.2 respirable fraction for the total release fraction from Ref. 5 ). With respect to the $32-\mathrm{kg}$ batch of in-process powder, the powder stored in interim containers is assumed to be subjected to damage. A $1 \times 10^{3}$ airborne release fraction and a 0.1 respirable fraction for the total release fraction was selected from Ref. 5 based on falling equipment impacting storage cans of powder. No credit is taken for the glove boxes that were postulated to fail. However, other portions of the process operation were assumed to be resistant to the event because of the material form. Finished pellets and fuel rods were not considered to constitute a significant portion of dispersible material. The source term is assumed to be filtered (leak-path factor of $1 \times 10^{-5}$ ) and released to a stack.

\subsubsection{Frequency estimate}

The frequency estimate for this event varies widely, depending on the site selected (and its respective seismic profile), the building used (and its evaluation basis), and the internal arrangement of equipment (see Sect. 7.5). Generally, a frequency estimate of $1 \times 10^{-2}$ to $1 \times 10^{-4}$ is used for this event (the frequency is usually closer to lower end of this range).

\subsubsection{Evaluation Basis Fire Event}

\subsubsection{Discussion}

A large spectrum of fire events ranging from small fires with no impacts to large multiroom fires with major impacts can be postulated for the LA fabrication building. Unlike the large MOX fabrication facility, the LA mission will take place in an existing building. While many existing buildings within the DOE complex are adequately covered by an existing fire protection program, it is reasonable to conclude that existing buildings might be more susceptible to fires (as compared to a new facility where fire protection can be incorporated into the design). However, the existing buildings must still meet the appropriate DOE orders.

A source of combustible material such as hydraulic fluid, alcohol, contaminated combustibles, or some other material is assumed to be present in the room. In addition, adjoining facilities such as offices may exist in the building and add to the risk of fires in the facility. The glove boxes are assumed to fail in the fire. This event is assumed to be a moderate-size room fire. The MOX powder that is in interim storage is assumed to be at risk and subjected to the thermal stress of the fire, because the glove box fails. Because of the limited combustible material and/or the existence of mitigators such as a fire protection system or arrival of the firefighting unit, the event is assumed to be terminated. The severity of this fire is not enough to jeopardize the overall confinement characteristics of the building.

\subsubsection{Source term}

Table 17 shows the materials in process along with the release fractions that were used. With respect to the oxide containers $(10 \mathrm{~kg})$, a high release fraction was selected based on a pressurized gas release combined with powder. This corresponds to a highly pressurized, strong, single can that ruptures under a high thermal stress because of pressure and ejects powder from the breached container. A $10 \%$ damage ratio (thus, $500 \mathrm{~g}$ of powder are subjected to the release fraction) was selected on the basis that the release fraction does not apply universally to all of the powder in the can (the release fraction will go down as larger cans of powder are subjected to the energetics).

The 32-kg inventory in the process area was assumed to be evenly split between the master mix and MOX fuel blend storage areas. The entire interim storage inventory of MOX powder is assumed to be subjected to a release fraction corresponding to thermal stress $\left(6 \times 10^{3}\right.$ airborne release fraction and a 0.01 respirable fraction from Ref. 5 ). Green pellets, finished pellets, and fuel rods were not considered to constitute a significant portion of dispersible material. The material is assumed to be filtered and released to a stack. The scrap area was assumed to contain mostly solid material and was not judged to be a significant 
Table 17. Source term for the evaluation basis fire

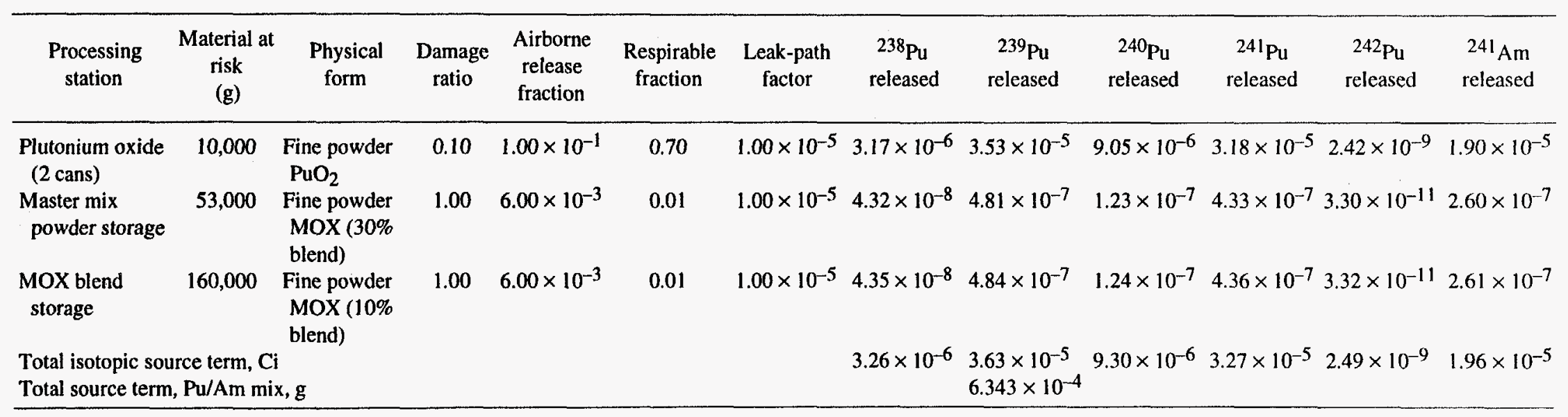


source of dispersible material. As with other source terms no credit was taken for in-facility filters, as these may fail because of the fire. The source term is filtered and released to a stack.

\subsubsection{Frequency estimate}

The frequency estimate of fires depends on the conduct of operations, the building selected, the adequacy of the fire protection program, and a number of other variables. A frequency estimate of between $1 \times 10^{-2} /$ year and $1 \times 10^{-4} /$ year (unlikely) is judged to be appropriate for this event because a relatively small area is assumed to be involved.

\subsubsection{Evaluation Basis Explosion Event}

\subsubsection{Discussion}

As was the case in Ref. 2, an explosion event was postulated for the sintering furnace in the LA fabrication facility. A nonexplosive mixture of $6 \%$ hydrogen and $94 \%$ argon is used in the furnace. Multiple equipment and operator errors would have to occur to enable an explosive mixture of hydrogen mixed with air to build up in the box. As a result of the explosion, green pellets are assumed to be subjected to the direct force of the resultant shock waves. Unlike Ref. 3, where the facility layout can accommodate segregation (in effect limiting the explosion damage), it is assumed that the glove boxes involved in powder blending are damaged indirectly by the explosion. It is not expected that the shock wave impacting this area would be severe enough to significantly damage all of the storage inventory because interim storage cans would provide some mitigation.

\subsubsection{Source term}

The split in the material at risk (between green pellets, pellets in the furnace, and powder storage areas) is shown in Table 18 for the $32-\mathrm{kg}$ batch. No specific release fractions are given in the literature for deflagration forces on green pellets that are pressed to $\sim 60 \%$ theoretical density. Reference 5 , Sect. 4.3.3, discusses a formulation for determining the product of the airborne release fraction and respirable fraction (ARF*RF) for dropped uranium dioxide pellets. A release fraction (combined ARF*RF) of $1 \times 10^{-4}$ was deemed to be conservative for all material $(40,000 \mathrm{~g})$ in the furnace subjected to explosive forces. This same release and respirable fraction was also used for the green pellets that would be pressed and likely near the furnace. The $80,000 \mathrm{~g}$ of green pellets would be a little further from the blast and in trays or containers. The same release fraction was applied to these green pellets and is thought to be conservative.

The remaining part of the $20-\mathrm{kg}$ batch was assumed to be split between the MOX master blend and powder storage stations. The MOX powder in the blending areas would likely be in a different glove box and somewhat removed from the blast. These glove boxes are assumed to be indirectly damaged from the explosion. As previously stated, most of the storage powder would be in interim cans that would merely be displaced. Powders in a glove box that undergo damage from external explosions are discussed in Ref. 5 (p. 4-69) . A release fraction (and respirable fraction) of $5 \times 10^{3}$ (and 0.3) was used and conservatively applied to all of the powder. The total source term is shown in Table 18. The building confinement is judged to be still intact resulting in a filtered stack release.

\subsubsection{Frequency estimate}

Because no definitive designs for the furnace and glove boxes currently exist, estimation of the probability of this event is difficult at this time. A judgment was made that the frequency of this event is extremely unlikely (between $1 \times 10^{-4} /$ year and $1 \times 10^{-6} /$ year). Such an explosion of sufficient size from the furnace to impact the glove boxes would only be possible because of a combination of equipment failure and human error. 
Table 18. Source term for the evaluation basis explosion

\begin{tabular}{|c|c|c|c|c|c|c|c|c|c|c|c|c|}
\hline $\begin{array}{l}\text { Processing } \\
\text { station }\end{array}$ & $\begin{array}{c}\text { Material at } \\
\text { risk } \\
\text { (g) }\end{array}$ & $\begin{array}{l}\text { Physical } \\
\text { form }\end{array}$ & $\begin{array}{l}\text { Damage } \\
\text { ratio }\end{array}$ & $\begin{array}{l}\text { Airborne } \\
\text { release } \\
\text { fraction }\end{array}$ & $\begin{array}{l}\text { Respirable } \\
\text { fraction }\end{array}$ & $\begin{array}{l}\text { Leak-path } \\
\text { factor }\end{array}$ & 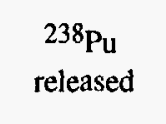 & ${ }^{239} \mathrm{Pu}$ & $\begin{array}{l}{ }^{240} \mathrm{Pu} \\
\text { released }\end{array}$ & ${ }^{241} \mathrm{Pu}$ & $\begin{array}{l}{ }^{242} \mathrm{Pu} \\
\text { released }\end{array}$ & ${ }^{241} \mathrm{Am}$ \\
\hline $\begin{array}{l}\text { Master mix } \\
\text { powder storage }\end{array}$ & 33,000 & $\begin{array}{l}\text { Fine powder } \\
\text { MOX ( } 30 \% \\
\text { blend) }\end{array}$ & 1.00 & $5.00 \times 10^{-3}$ & 0.3 & $1.00 \times 10^{-5}$ & $6.73 \times 10^{-7}$ & $7.49 \times 10^{-6}$ & $1.92 \times 10^{-6}$ & $6.75 \times 10^{-6}$ & $5.14 \times 10^{-10}$ & $4.04 \times 10^{-6}$ \\
\hline $\begin{array}{l}\text { MOX blend } \\
\text { storage }\end{array}$ & 100,000 & $\begin{array}{l}\text { Fine powder } \\
\text { MOX (10\% } \\
\text { blend) }\end{array}$ & 1.00 & $5.00 \times 10^{-3}$ & 0.3 & $1.00 \times 10^{-5}$ & $6.79 \times 10^{-7}$ & $7.57 \times 10^{-6}$ & $1.94 \times 10^{-6}$ & $6.81 \times 10^{-6}$ & $5.19 \times 10^{-10}$ & $4.08 \times 10^{-6}$ \\
\hline $\begin{array}{l}\text { MOX green } \\
\text { pellet storage } \\
\text { (in pellet press } \\
\text { area) }\end{array}$ & 80,000 & $\begin{array}{l}\text { Pressed to } 0.6 \\
\text { TD, MOX } \\
\text { (10\% blend) }\end{array}$ & 1.00 & $1.00 \times 10^{-4}$ & 1 & $1.00 \times 10^{-5}$ & $3.62 \times 10^{-8}$ & $4.04 \times 10^{-7}$ & $1.03 \times 10^{-7}$ & $3.63 \times 10^{-7}$ & $2.77 \times 10^{-11}$ & $2.18 \times 10^{-7}$ \\
\hline $\begin{array}{l}\text { Pellet sintering } \\
\text { furnace }\end{array}$ & 40,000 & $\begin{array}{l}\text { Assume all } \\
\text { green pellets } \\
\text { MOX (10\% } \\
\text { blend) }\end{array}$ & 1.00 & $1.00 \times 10^{-4}$ & 1 & $1.00 \times 10^{-5}$ & $1.81 \times 10^{-8}$ & $2.02 \times 10^{-7}$ & $5.17 \times 10^{-8}$ & $1.82 \times 10^{-7}$ & $1.39 \times 10^{-11}$ & $1.09 \times 10^{-7}$ \\
\hline \multicolumn{7}{|c|}{$\begin{array}{l}\text { Total isotopic source term, } \mathrm{Ci} \\
\text { Total source term, } \mathrm{Pu} / \mathrm{Am} \text { mix, } \mathrm{g}\end{array}$} & $1.41 \times 10^{-6}$ & $\begin{array}{l}1.57 \times 10^{-5} \\
2.739 \times 10^{-4}\end{array}$ & $4.02 \times 10^{-6}$ & $1.41 \times 10^{-5}$ & $1.08 \times 10^{-9}$ & $8.45 \times 10^{-6}$ \\
\hline
\end{tabular}




\subsubsection{Beyond-Evaluation Basis Seismic Event}

\subsubsection{Discussion}

In this analysis an event much more severe in consequences than what might be expected to be the design basis (or evaluation basis) is examined. For some existing DOE facilities, the estimated seismic frequency for beyond-design basis events can be greater than $1 \times 10^{-6} /$ year. The design basis for every building in the complex varies considerably depending on site specifics and the type of construction used in the building. A damage assessment of the facility is further complicated by the fact that seismic considerations could also be incorporated in the glove box design of the facility. In reality, such a catastrophic event may or may not demolish the building and/or the glove boxes. However, for the purposes of illustrating a high consequence accident (which occurs at a very low frequency), total demolition of the building has been assumed. In this event, no credit is taken for the building, the filters, or the glove boxes.

\subsubsection{Source term}

In the evaluation basis seismic event previously discussed, credit was taken for the 3013 cans (which have double containment) in the vault storage area. In this event, however, a total building collapse is used, and a judgment was made that a few of the containers may fail. A damage ratio of 0.05 was used; it equates to 4 out of 80 cans in the vault area. For the source term evaluation of the remainder of the in-process material (including the two cans that feed the process), the release fractions were selected to be the same as in the evaluation basis seismic event. However, because it is assumed that the building collapses and the ventilation system is severed, no credit is taken for filtration. This results in a building leak-path factor of 1.0. The source term is assumed to be released at or near ground level $(10 \mathrm{~m})$. Table 19 shows the source term for this event.

\subsubsection{Frequency}

As discussed previously there is great difficulty in assigning a frequency for this event, especially because facilities are not analyzed for very high seismic events that occur with very infrequent return periods. Site specifics make the frequency assessment of this event very uncertain as well. For the sake of this analysis, a frequency value of $1 \times 10^{-6}$ or less is thought to be appropriate for the EIS purposes.

\subsubsection{Beyond-Evaluation Basis Major Building Fire}

\subsubsection{Discussion}

Fuel manufacturing operations do not lend themselves to the use of large significant amounts of combustible material. In this scenario, however, it is assumed that the building is burned for a considerable length of time, resulting in a total collapse of the building. This event could also roughly be characterized as a large fire following a total building collapse.

\subsubsection{Source term}

Some thought was given to the stability of the 3013 cans in the vault which would be subjected to prolonged heat during a large fire. Because of the double containment and high-pressure rating for the cans, it was judged that the cans could withstand a large building fire. However, because a major building fire breaches the confinement, it is assumed that the building structure could collapse. This happens in large buildings subjected to high heat loads for long periods of time. As a result of this consideration, four of the cans in the vault area were assumed to have breached, just as in the beyond-evaluation seismic event. For the two oxide cans in process, it was conservatively assumed that they burst (previously discussed in the evaluation-basis fire scenario). The remainder of the $32-\mathrm{kg}$ inventory was assumed to be subjected to a 
Table 19. Source term for beyond the evaluation basis seismic event (total building collapse assumed)

\begin{tabular}{|c|c|c|c|c|c|c|c|c|c|c|c|c|}
\hline $\begin{array}{l}\text { Processing } \\
\text { station }\end{array}$ & $\begin{array}{c}\text { Material at } \\
\text { risk } \\
\text { (g) }\end{array}$ & $\begin{array}{l}\text { Physical } \\
\text { form }\end{array}$ & $\begin{array}{l}\text { Damage } \\
\text { ratio }\end{array}$ & $\begin{array}{l}\text { Airborne } \\
\text { release } \\
\text { fraction }\end{array}$ & $\begin{array}{l}\text { Respirable } \\
\text { fraction }\end{array}$ & $\begin{array}{l}\text { Leak-path } \\
\text { factor }\end{array}$ & 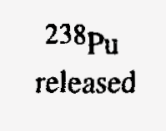 & ${ }^{239} \mathrm{Pu}$ & $\begin{array}{l}{ }^{240} \mathrm{Pu} \\
\text { released }\end{array}$ & ${ }^{241} \mathrm{Pu}$ & $\begin{array}{l}{ }^{242} \mathrm{Pu} \\
\text { released }\end{array}$ & $\begin{array}{l}241 \mathrm{Am} \\
\text { released }\end{array}$ \\
\hline $\begin{array}{l}\text { Plutonium } \\
\text { storage vault }\end{array}$ & 400,000 & $\begin{array}{l}\text { Fine powder } \\
\mathrm{PuO}_{2}\end{array}$ & 0.05 & $1.00 \times 10^{-3}$ & 0.10 & $1.00 \times 10^{0}$ & $9.06 \times 10^{-3}$ & $1.01 \times 10^{-1}$ & $2.59 \times 10^{-2}$ & $9.08 \times 10^{-2}$ & $6.93 \times 10^{-6}$ & $5.44 \times 10^{-2}$ \\
\hline $\begin{array}{l}\text { Plutonium oxide } \\
\text { ( } 2 \text { cans) }\end{array}$ & 10,000 & $\begin{array}{l}\text { Fine powder } \\
\mathrm{PuO}_{2}\end{array}$ & 1.00 & $1.00 \times 10^{-2}$ & 0.20 & $1.00 \times 10^{0}$ & $9.06 \times 10^{-2}$ & $1.01 \times 10^{0}$ & $2.59 \times 10^{-1}$ & $9.08 \times 10^{1}$ & $6.93 \times 10^{-5}$ & $5.44 \times 10^{-1}$ \\
\hline $\begin{array}{l}\text { Master mix } \\
\text { powder storage }\end{array}$ & 53,000 & $\begin{array}{l}\text { Fine powder } \\
\text { MOX ( } 30 \% \\
\text { blend) }\end{array}$ & 1.00 & $1.00 \times 10^{-3}$ & 0.10 & $1.00 \times 10^{0}$ & $7.20 \times 10^{-3}$ & $8.02 \times 10^{-2}$ & $2.06 \times 10^{-2}$ & $7.22 \times 10^{-2}$ & $5.51 \times 10^{-6}$ & $4.33 \times 10^{-2}$ \\
\hline $\begin{array}{l}\text { MOX blend } \\
\text { storage }\end{array}$ & 160,000 & $\begin{array}{l}\text { Fine powder } \\
\text { MOX (10\% } \\
\text { blend) }\end{array}$ & 1.00 & $1.00 \times 10^{-3}$ & 0.10 & $1.00 \times 10^{0}$ & $7.25 \times 10^{-3}$ & $8.07 \times 10^{-2}$ & $2.07 \times 10^{-2}$ & $7.27 \times 10^{-2}$ & $5.54 \times 10^{-6}$ & $4.35 \times 10^{-2}$ \\
\hline \multicolumn{7}{|c|}{ Total isotopic source term, $\mathrm{Ci}$} & $1.14 \times 10^{-1}$ & $1.27 \times 10^{0}$ & $3.26 \times 10^{-1}$ & $1.14 \times 10^{-0}$ & $8.72 \times 10^{-5}$ & $6.85 \times 10^{-1}$ \\
\hline \multicolumn{8}{|c|}{ Total source term, Pu/Am mix, $g$} & 22.22 & & & & \\
\hline
\end{tabular}


release fraction corresponding to falling debris in cans (similar to a seismic event). The total estimated source term is shown in Table 20 . However, because considerable heat is produced by the fire, a significant plume rise would occur. Therefore, a release height of $100 \mathrm{~m}$ was judged to be appropriate for this event.

\subsubsection{Frequency.}

Assigning a frequency for this event is difficult because significant combustible loads are not placed in close proximity to the process. This is a very low frequency non-credible event, which requires the introduction of significant combustibles that would create a fire large enough to collapse the structure. For the sake of this analysis, a frequency value of much less than $1 \times 10^{-7}$ is thought to be appropriate for the EIS purposes.

\subsection{EVALUATION OF POTENTIAL CHEMICAL SOURCE TERMS}

Chemical and radiological materials used in this facility were previously given in Table 7. With respect to radiological effects, the source terms associated with plutonium oxide constitute an overwhelming majority of the radiological risk. With respect to the chemical hazards associated with depleted $\mathrm{UO}_{2}$ (which are released in conjunction with the plutonium oxide in the scenarios outlined in the previous sections), no specific source terms have been generated in this analysis. As discussed in previous sections, only small amounts of plutonium (generally $<1 \mathrm{~g}$ ) constitute the source terms. If treated similarly (from a release standpoint), small amounts of the depleted uranium that may accompany the plutonium oxide that escapes the building are judged to be inconsequential.

Table 7 also gives the other chemicals and compounds that will be used annually by the facility and lists the yearly consumption of gases, liquids, and solids. With respect to any possibly chemical source term, the gases listed (i.e., helium, hydrogen, nitrogen, and oxygen) do not constitute an inhalation or exposure hazard in the context of LA fabrication operations. Reportable quantities of various chemical compounds are cited in 40 CFR 302, Table 302.4. If a chemical company operator spills less than these quantities, the Environmental Protection Agency is not notified. While this is not an absolute criterion that guarantees the lack of off-site consequences, it is illustrative to examine the yearly flow of chemicals based on these reported quantities.

Table 21 compares the annual usage of chemicals to the reportable quantities for that material. While not all materials are listed, the comparison shows that the LA facility does not constitute a major source of chemical inventories. The chemicals listed are either in a liquid or solid form, and the gases listed are not hazardous from an inhalation perspective. Typical occupational chemical exposure incidents, such as acid burns to a worker, are certainly credible. A significant release scenario (inhalation risk, ingestion risk, or skin contact risk) that constitutes a source term (with a magnitude of reasonable concern) to a receptor is difficult to credibly postulate at this stage of the facility analysis. Because of the small size of the facility and the small quantities of chemicals that are expected to be on hand, it is concluded that no chemical source terms are worthy of analysis (that are beyond what is found in small standard industrial facilities). The amounts that would be in use by this facility are certainly considered to be well within the scope of typical industrial hazards found in laboratory environments.

\subsection{SITE SPECIFICS FOR THE ANL BUILDING 704}

\subsubsection{Stack Release Height}

For ANL Building 704 , the stack release height is $\sim 11.3 \mathrm{~m}(\sim 37 \mathrm{ft})$.

\subsubsection{Evaluated Seismic Attributes}

For Building 704, the current value of the evaluated peak ground acceleration for the manufacturing and vault area is $0.22 \mathrm{~g}$, with an estimated frequency of $5 \times 10^{-4}$ per year. The support wing was designed 
Table 20. Source term for beyond the evaluation basis major building fire/building collapse (total building collapse assumed to result; source term release height $\mathbf{= 1 0 0} \mathbf{~ m}$ )

\begin{tabular}{|c|c|c|c|c|c|c|c|c|c|c|c|c|}
\hline $\begin{array}{l}\text { Processing } \\
\text { station }\end{array}$ & $\begin{array}{l}\text { Material at } \\
\text { risk } \\
\text { (g) }\end{array}$ & $\begin{array}{l}\text { Physical } \\
\text { form }\end{array}$ & $\begin{array}{l}\text { Damage } \\
\text { ratio }\end{array}$ & $\begin{array}{l}\text { Airborne } \\
\text { release } \\
\text { fraction }\end{array}$ & $\begin{array}{l}\text { Respirable } \\
\text { fraction }\end{array}$ & $\begin{array}{l}\text { Leak-path } \\
\text { factor }\end{array}$ & $\begin{array}{l}{ }^{238} \mathrm{Pu} \\
\text { released }\end{array}$ & $\begin{array}{l}{ }^{239} \mathrm{Pu} \\
\text { released }\end{array}$ & $\begin{array}{l}240_{\mathrm{Pu}} \\
\text { released }\end{array}$ & $\begin{array}{l}{ }^{241} \mathrm{Pu} \\
\text { released }\end{array}$ & $\begin{array}{l}{ }^{242} \mathrm{Pu} \\
\text { released }\end{array}$ & $\begin{array}{l}{ }^{241} \mathrm{Am} \\
\text { released }\end{array}$ \\
\hline $\begin{array}{l}\text { Plutonium } \\
\text { storage vault }\end{array}$ & 400,000 & $\begin{array}{l}\text { Fine powder } \\
\mathrm{PuO}_{2}\end{array}$ & 0.05 & $1.00 \times 10^{-3}$ & 0.10 & $1.00 \times 10^{0}$ & $9.06 \times 10^{-3}$ & $1.01 \times 10^{-1}$ & $2.59 \times 10^{-2}$ & $9.08 \times 10^{-2}$ & $6.93 \times 10^{-6}$ & $5.44 \times 10^{-2}$ \\
\hline $\begin{array}{l}\text { Plutonium oxide } \\
\text { ( } 2 \text { cans) }\end{array}$ & 10,000 & $\begin{array}{l}\text { Fine powder } \\
\mathrm{PuO}_{2}\end{array}$ & 0.10 & $1.00 \times 10^{-1}$ & 0.70 & $1.00 \times 10^{0}$ & $3.17 \times 10^{-1}$ & $3.53 \times 10^{0}$ & $9.05 \times 10^{-1}$ & $3.18 \times 10^{0}$ & $2.42 \times 10^{-4}$ & $1.90 \times 10^{0}$ \\
\hline $\begin{array}{l}\text { Master mix } \\
\text { powder storage }\end{array}$ & 53,000 & $\begin{array}{l}\text { Fine powder } \\
\text { MOX ( } 30 \% \\
\text { blend) }\end{array}$ & 1.00 & $1.00 \times 10^{-3}$ & 0.10 & $1.00 \times 10^{0}$ & $7.20 \times 10^{-3}$ & $8.02 \times 10^{-2}$ & $2.06 \times 10^{-2}$ & $7.22 \times 10^{-2}$ & $5.51 \times 10^{-6}$ & $4.33 \times 10^{-2}$ \\
\hline $\begin{array}{l}\text { MOX blend } \\
\text { storage }\end{array}$ & 160,000 & $\begin{array}{l}\text { Fine powder } \\
\text { MOX (10\% } \\
\text { blend) }\end{array}$ & 1.00 & $1.00 \times 10^{-3}$ & 0.10 & $1.00 \times 10^{0}$ & $7.25 \times 10^{-3}$ & $8.07 \times 10^{-2}$ & $2.07 \times 10^{-2}$ & $7.27 \times 10^{-2}$ & $5.54 \times 10^{-6}$ & $4.35 \times 10^{-2}$ \\
\hline \multicolumn{3}{|c|}{$\begin{array}{l}\text { Total isotopic source term, } \mathrm{Ci} \\
\text { Total source term, } \mathrm{Pu} / \mathrm{Am} \mathrm{mix}, \mathrm{g}\end{array}$} & & & & & $3.41 \times 10^{-1}$ & $\begin{array}{l}3.79 \times 10^{0} \\
66.32\end{array}$ & $9.72 \times 10^{-1}$ & $3.42 \times 10^{0}$ & $2.60 \times 10^{-4}$ & $2.05 \times 10^{0}$ \\
\hline
\end{tabular}


Table 21. Comparison of LA facility annual usage and reportable quantity per 40 CFR 302

\begin{tabular}{lcl}
\hline \multicolumn{1}{c}{ Item } & $\begin{array}{c}\text { Annual average } \\
\text { consumption }\end{array}$ & $\begin{array}{c}\text { Reportable } \\
\text { quantity }\end{array}$ \\
\hline Liquids & $1 \mathrm{lb}$ & $5,000 \mathrm{lb}$ \\
Hydrochloric acid & $2 \mathrm{lb}$ & $1,000 \mathrm{lb}$ \\
Nitric acid & $<45 \mathrm{lb}$ & Not listed \\
Polyethylene glycol & $5 \mathrm{lb}$ & $1,000 \mathrm{lb}$ \\
Sulfuric acid & & \\
Solids & $34 \mathrm{lb}$ & $1,000 \mathrm{lb}$ \\
Sodium hydroxide & $<200 \mathrm{lb}$ & Not listed \\
Sodium nitrate & $<45 \mathrm{lb}$ & Not listed \\
Zinc stearate & & \\
Nonprocess chemicals & $60 \mathrm{gal}$ & Not listed \\
Alcohol & $10 \mathrm{lb}$ & Not listed \\
Hydraulic fluid & $60 \mathrm{gal}$ & Not listed \\
General cleaning fluids & & \\
\hline
\end{tabular}

using Uniform Building Code methods. This corresponds to a peak ground acceleration of $0.21 \mathrm{~g}$ and a frequency of $1 \times 10^{-3} /$ year.

These estimates do not consider the equipment specifics that would be involved in the MOX LA fabrication line and represent an estimate for the building and confinement-related ventilation system. Cross-comparisons of frequencies and evaluation basis values among different sites must be performed with caution. Such simple comparisons do not take into account the differences in analytical approaches that were used at each site to estimate both the building response, acceleration, or estimated frequency for the site. As a general rule for all sites, it is expected that the evaluation basis frequency for a seismic event would be from $1 \times 10^{-2} /$ year to $1 \times 10^{-4} /$ year and would likely be between $1 \times 10^{-3} /$ year and $1 \times 10^{-4} /$ year. 
Page Intentionally Blank 


\section{TRANSPORTATION}

\subsection{OPERATIONS-RELATED TRANSPORTATION REQUIREMENTS}

Production of MOX fuel LAs, irradiation of the LAs in commercial reactors, and subsequent PIE will result in a number of packaging and transportation operations to (1) obtain the necessary feed materials to manufacture LAs, (2) package and transport the completed fuel assemblies from the fabrication facility to the commercial reactor, and (3) package and transport the irradiated fuel assemblies from the commercial reactor to another facility for PIE.

Plans for MOX fuel LA testing involve manufacture of up to ten MOX fuel LAs, with up to eight LAs undergoing irradiation while the remaining LAs are maintained as unirradiated archives. Each LA could contain from as few as one-third MOX rods (with the balance of the rods being LEU) to an entire assembly composed of MOX rods. Under these circumstances, production of LA will require that LEU and MOX fuel rods be combined in a single assembly. This activity could occur at either the LA fabrication facility or at the reactor facility. While reactors generally have the ability to substitute individual rods within an assembly (due to detected damage), it is expected that exchanging as many as one-third of the LEU assembly rods with MOX rods would occur at the LA facility.

\subsubsection{Feed Materials}

Table 22 provides information about the shipment of $\mathrm{PuO}_{2}$. Table 23 provides information about the shipment of depleted $\mathrm{UO}_{2}$. Depleted $\mathrm{UO}_{2}$ can be obtained by the consortium, or DOE will provide either depleted uranium fluoride $\left(\mathrm{DUF}_{6}\right)$ or depleted uranium oxide $\left(\mathrm{DUO}_{3}\right)$ for conversion by the consortium. Other materials (e.g., new empty fuel rods, end plugs, grid spacers, and other assembly hardware) are not "regulated" materials for transportation. Their shipment would not require special packaging, other than to protect the economic value of the commodity. The specific LA design is uncertain. Some designs may have every fuel rod contain MOX, while other designs may have both $\mathrm{MOX}$ and $\mathrm{UO}_{2}$ fuel rods within a bundle. In the latter case, it would be necessary to either ship enriched $\mathrm{UO}_{2}$ fuel rods (or $\mathrm{UO}_{2}$ fuel rods in $\mathrm{LEU}$ fuel assemblies) to the MOX fabrication facility or to ship MOX fuel rods from the fabrication facility to the commercial fuel fabrication site (for insertion in LEU fuel assemblies shipped separately to the reactor). If the MOX LA will contain a large fraction of MOX rods (one-third or more), it is expected that the LA facility will need to receive LEU fuel assemblies (possibly, with unfilled rod positions) from a commercial fuel vendor. The LA fuel facility would then place MOX rods within the assembly and package the MOX LA for shipment to the reactor. Table 24 provides information on the shipment of LEU fuel assemblies to the MOX LA fuel facility, if needed.

\subsubsection{Fresh MOX Fuel Assemblies}

Table 25 provides information about the transport of fresh (unirradiated) MOX fuel from the fabrication facility to the commercial reactor, while Table 26 provides the fresh MOX fuel isotopic contents. The same package identified for shipment of the MOX fuel assemblies (the MO-1) would also be used to ship groups of individual MOX fuel rods to a commercial fuel fabrication site for insertion in a MOX fuel bundle if this approach is used.

\subsubsection{Spent MOX Fuel Assemblies}

Tables 27 and 28 provide information about the transport of spent (irradiated) MOX fuel from the commercial reactor to the PIE facility. Table 29 provides information regarding existing casks that could be used to transport spent MOX fuel to the PIE facility. The number of shipments of spent MOX fuel will depend on the actual plans for LA irradiation and plans for subsequent PIE. Based on the schedule described in Fig. 2, up to eight shipments of LA spent fuel could be transported between the reactor and the PIE facility. 
Table 22. Transportation of $\mathrm{PuO}_{2}$ to support LA fabrication

Number of shipments to LA fabrication site ${ }^{a}$

1 or more

Assuming $321 \mathrm{~kg} \mathrm{HM}$ of plutonium as $\mathrm{PuO}_{2}$ is needed for startup and to produce 10 LTAs

Would require about 73 packages ( $4.4 \mathrm{~kg} \mathrm{HM}$ /package). SST could accommodate 30 to 35 packages per trailer. Single SST convoy (three trailers) could deliver entire $\mathrm{PuO}_{2}$ supply for LTA campaign.

Container types used for shipments

Availability of containers

Likely candidate package would be 9968 or 9975 , perhaps SAFKEG

Only 9968 is currently certified

Average shipping container weight

Average material weight loaded into container

Average isotopic contents

Average exposure rate at $1 \mathrm{~m}$

Maximum anticipated dose rate at $1 \mathrm{~m}$

Will need to be determined

Regulatory limits are $200 \mathrm{mrem} / \mathrm{h}$ at surface of package $(1000 \mathrm{mrem} / \mathrm{h}$ for closed transport vehicles, exclusive use, cargo secured); $200 \mathrm{mrem} / \mathrm{h}$ (outer surface of vehicle); $10 \mathrm{mrem} / \mathrm{h}$ at point $2 \mathrm{~m}$ from package surface; and $2 \mathrm{mrem} / \mathrm{h}$ (in occupied spaces) (i.e., crew cab, etc.)

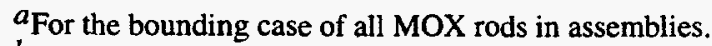

$b_{\text {See Table } 26 .}$

Table 23. Transportation of depleted $\mathrm{UO}_{2}$ to support $\mathrm{LA}$ fabrication ${ }^{a, b}$

Number of shipments to LA fabrication site

1

$\mathrm{UO}_{2}$ is shipped in standard metal drums

Truck could accommodate $40,000 \mathrm{lb}(\sim 72$ drums)

Mission would only require about 28 drums $\mathrm{UO}_{2}$

Container types used for shipments

208-L drum

A strong-tight container (open head 55-gal drum)

Probably use UN1A2 (steel drum)

Availability of containers

Type B

Yes

$165 \mathrm{~kg}(360 \mathrm{lb})$

$4.4-4.5 \mathrm{~kg} \mathrm{HM}$

$b$

$0.1 \mathrm{mrem} / \mathrm{h}$

$10 \mathrm{mrem} / \mathrm{h}$

Average shipping container weight, $\mathrm{kg}(\mathrm{lb})$

Average material weight loaded into container

Average isotopic contents

Average exposure rate at $1 \mathrm{~m}$

Maximum anticipated dose rate at $1 \mathrm{~m}$

Will need to be determined

Regulatory limits are $200 \mathrm{mrem} / \mathrm{h}$ at surface of package $(1000 \mathrm{mrem} / \mathrm{h}$ for closed transport vehicles, exclusive use, cargo secured); $200 \mathrm{mrem} / \mathrm{h}$ (outer surface of vehicle); $10 \mathrm{mrem} / \mathrm{h}$ at point $2 \mathrm{~m}$ from package surface; and $2 \mathrm{mrem} / \mathrm{h}$ (in occupied spaces) (i.e., crew cab, etc.)

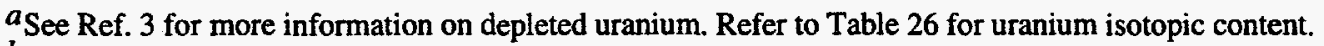

$b_{\text {Unlike }} \mathrm{UF}_{6}$ cylinders, depleted $\mathrm{UO}_{2}$ is purified, with daughter products removed that result in potential doses. 
Table 24. Transportation of materials to support LA fabrication (LEU fuel assemblies)

Number of shipments of LA fabrication site

Assuming that all $10 \mathrm{LEU}$ assemblies could be shipped on a single commercial vehicle (just as LEU fuel is shipped currently). Would require use of 5 LEU fuel packages.

Container types used for shipments

Availability of containers

Average shipping container weight, $\mathrm{kg}(\mathrm{lb})$

Average material weight loaded into container

Average isotopic contents

Average exposure rate at $1 \mathrm{~m}, \mathrm{mR} / \mathrm{h}$

Maximum anticipated dose rate at $1 \mathrm{~m}, \mathrm{mR} / \mathrm{h}$

Will need to be determined

Regulatory limits are $200 \mathrm{mrem} / \mathrm{h}$ at surface of package $(1000 \mathrm{mrem} / \mathrm{h}$ for closed transport vehicles, exclusive use, cargo secured); $200 \mathrm{mrem} / \mathrm{h}$ (outer surface of vehicle); $10 \mathrm{mrem} / \mathrm{h}$ at point $2 \mathrm{~m}$ from package surface; and $2 \mathrm{mrem} / \mathrm{h}$ (in occupied spaces) (i.e., crew cab, etc.)
Type AF

Yes

$2900 \mathrm{~kg}(6300 \mathrm{lb})$ to

$3800 \mathrm{~kg}(8400 \mathrm{lb})$

$1400 \mathrm{~kg}(3000 \mathrm{lb})$

LEU, up to $5 \%{ }^{235} \mathrm{U}$

$\sim 0$ (not measurable)

$10 \mathrm{mrem} / \mathrm{h}$

Table 25. Transportation of LAs to generic reactor site

Number of SST shipments of LAs to generic reactor

Assuming two shipments (four assemblies) each to two different reactors, with two additional assemblies archived.

Type of containers used for shipments

Likely candidate is the MO-1, USA/9069/B

Potential problems-NRC may require additional analysis to continue inclusion of MOX contents on package certificate. Also, MO-1 certificate lists $85 \%$ fissile plutonium in total plutonium. WG MOX would be $-94 \%$, so additional analysis is needed to ensure that LTAs can be transported in MO-1 (may need to enhance criticality controls).

No package currently available in the United States for boiling-water reactor (BWR) MOX assemblies; probably could amend MO-1 certificate to allow two BWR assemblies

Availability of containers

Average shipping container weight

Gross weight, including two pressurized-water reactor (PWR) fuel assemblies

Average material weight loaded into shipping container

Average isotopic content (by isotope, mass \% content)

Average exposure rate at $1 \mathrm{~m}$

Will need to be determined, both for worker doses as well as transportation risk assessment

Should be fairly low

Maximum anticipated dose rate at $1 \mathrm{~m}$

Will need to be determined

Regulatory limits are $200 \mathrm{mrem} / \mathrm{h}$ at surface of package $(1000 \mathrm{mrem} / \mathrm{h}$ for closed transport vehicles, exclusive use, cargo secured); $200 \mathrm{mrem} / \mathrm{h}$ (outer surface of vehicle); $10 \mathrm{mrem} / \mathrm{h}$ at point $2 \mathrm{~m}$ from package surface; and $2 \mathrm{mrem} / \mathrm{h}$ (in occupied spaces) (i.e., crew cab, etc.)

${ }^{a}$ See Table 26.

Only two MO-1

packages exist $3900 \mathrm{~kg}(8600 \mathrm{lb})$

$-1400 \mathrm{~kg}(3000 \mathrm{lb})$

$a$

$0.1 \mathrm{mrem} / \mathrm{h}$

$10 \mathrm{mrem} / \mathrm{h}$ 
Table 26. Fresh MOX fuel isotopic content ${ }^{a}$

\begin{tabular}{cc}
\hline $\begin{array}{c}\text { Average isotopic content } \\
(\%)\end{array}$ & $\begin{array}{c}\text { Mass content } \\
(\%)\end{array}$ \\
\hline${ }^{235} \mathrm{U}, 0.2$ & 0.1915 \\
$238 \mathrm{U}, 99.8$ & 95.556 \\
$236 \mathrm{Pu},<1 \mathrm{ppb}$ & - \\
$238 \mathrm{Pu}, 0.03$ & 0.00053 \\
$239 \mathrm{Pu}, 92.44$ & 3.995 \\
$240 \mathrm{Pu}, 6.47$ & 0.2485 \\
$241 \mathrm{Pu}, 0.05$ & 0.00592 \\
$242 \mathrm{Pu}, 0.1$ & 0.00249 \\
$241 \mathrm{Am}, 0.9$ & 0.004 \\
\hline
\end{tabular}

${ }^{a}$ Source: Ref. 2.

Note: MOX fuel will be produced with various plutonium concentrations depending on the mission reactors.

Table 27. Transportation of irradiated LAs to PIE site

Number of shipments of irradiated LAs to PIE site Depending on cask selection, see Table 29

Types of container used for shipments

Availability of shipping containers

Several available choices dependent on previous commitments, ability of facilities to handle particular packages

Possible choices-NAC-LWT or NLI. Each would hold one PWR or two BWR assemblies

Average shipping container weight

Average material weight

Average isotopic content

Uranium, transuranics, fission products (dependent on burnup and decay time)

Average exposure rate at $1 \mathrm{~m}(\mathrm{mrem} / \mathrm{h})$ dependent on burnup and decay $\quad-10 \mathrm{mrem} / \mathrm{h}^{a}$ time

Maximum anticipated dose rate at $1 \mathrm{~m}$ Dependent on fuel burnup and decay plus selection of package Must be below regulatory limits
Up to 8

Type B

Yes

25-40 tons

$700-2100 \mathrm{~kg}(1500-4500 \mathrm{lb})$

See Table 28

${ }^{a}$ Each cask will be loaded to the maximum capacity without exceeding regulatory dose limits. 
Table 28. Spent MOX fuel isotopic content

\begin{tabular}{|c|c|}
\hline Isotope & Mass content ${ }^{a}$ (g/assembly) \\
\hline \multicolumn{2}{|c|}{ Actinides } \\
\hline${ }^{234} \mathrm{U}$ & $1.28 \times 10^{1}$ \\
\hline${ }^{235} \mathrm{U}$ & $3.56 \times 10^{2}$ \\
\hline${ }^{236} \mathrm{U}$ & $1.13 \times 10^{2}$ \\
\hline${ }^{238} \mathrm{U}$ & $4.25 \times 10^{5}$ \\
\hline${ }^{237} \mathrm{~Np}$ & $8.42 \times 10^{1}$ \\
\hline $238 \mathrm{Pu}$ & $9.70 \times 10^{1}$ \\
\hline${ }^{239} \mathrm{Pu}$ & $6.99 \times 10^{3}$ \\
\hline $240 \mathrm{Pu}$ & $4.06 \times 10^{3}$ \\
\hline${ }^{241} \mathrm{Pu}$ & $1.49 \times 10^{3}$ \\
\hline${ }^{242} \mathrm{Pu}$ & $7.50 \times 10^{2}$ \\
\hline${ }^{241} \mathrm{Am}$ & $1.04 \times 10^{3}$ \\
\hline $242 \mathrm{Am}$ & $3.22 \times 10^{0}$ \\
\hline${ }^{243} \mathrm{Am}$ & $2.03 \times 10^{2}$ \\
\hline${ }^{242} \mathrm{Cm}$ & $8.39 \times 10^{-3}$ \\
\hline${ }^{243} \mathrm{Cm}$ & $8.73 \times 10^{-1}$ \\
\hline${ }^{244} \mathrm{Cm}$ & $5.38 \times 10^{1}$ \\
\hline${ }^{245} \mathrm{Cm}$ & $5.40 \times 10^{0}$ \\
\hline \multicolumn{2}{|c|}{ Fission products } \\
\hline${ }^{90} \mathrm{Sr}$ & $1.31 \times 10^{2}$ \\
\hline${ }^{106} \mathrm{Ru}$ & $1.77 \times 10^{-1}$ \\
\hline $126 \mathrm{Sn}$ & $2.22 \times 10^{1}$ \\
\hline${ }^{126} \mathrm{Sb}$ & $1.06 \times 10^{-6}$ \\
\hline${ }^{134} \mathrm{Cs}$ & $2.81 \times 10^{0}$ \\
\hline${ }^{137} \mathrm{Cs}$ & $6.21 \times 10^{2}$ \\
\hline${ }^{144} \mathrm{Ce}$ & $2.21 \times 10^{-2}$ \\
\hline${ }^{147} \mathrm{Pm}$ & $6.71 \times 10^{0}$ \\
\hline $148 \mathrm{Nd}$ & $2.25 \times 10^{2}$ \\
\hline${ }^{154} \mathrm{Eu}$ & $1.30 \times 10^{1}$ \\
\hline
\end{tabular}

${ }^{a}$ Spent fuel composition is for MOX containing $4.56 \mathrm{wt} \%$ plutonium at a burnup of $45 \mathrm{GWd} / \mathrm{MT}, 10$ years after discharge. Table includes only most significant isotopes.

Source: Memorandum, B. D. Murphy to R. T. Primm III, "Computational Support to Yucca Mountain Project Environmental Impact Statement Data Call," September 12, 1997. 
Table 29. Examples of casks for LWR spent fuel

\begin{tabular}{|c|c|c|c|c|c|}
\hline Name & Owner & Certification No. & $\begin{array}{c}\text { Gross } \\
\text { weight } \\
\text { (lb) }\end{array}$ & Cavity size & Contents \\
\hline NAC-LWT & $\begin{array}{l}\text { NAC } \\
\text { International, } \\
\text { Norcross, GA }\end{array}$ & $\mathrm{USA} / 9225 / \mathrm{B}(\mathrm{U}) \mathrm{F}$ & 51,200 & $\begin{array}{l}\text { 181-in. long by } 13.4 \text {-in. } \\
\text { diam }\end{array}$ & $\begin{array}{l}1 \text { PWR or } 2 \\
\text { BWR } \\
\text { assemblies }\end{array}$ \\
\hline NLI-1/2 & $\begin{array}{l}\text { NAC } \\
\text { International, } \\
\text { Norcross, GA }\end{array}$ & USA/9010/B( )F & 49,250 & $\begin{array}{l}\text { 178-in. long by } 13.4 \text {-in. } \\
\text { diam }\end{array}$ & $\begin{array}{l}1 \text { PWR or } 2 \\
\text { BWR } \\
\text { assemblies }\end{array}$ \\
\hline $\mathrm{TN}-8 \mathrm{~L}$ & $\begin{array}{l}\text { Transnuclear, } \\
\text { Hawthorne, NY }\end{array}$ & USA/9015/B( )F & 79,380 & $\begin{array}{l}3 \text { cavities, } \\
9 \text { in. } \times 9 \text { in. } \times 168.5 \text { in. }\end{array}$ & $\begin{array}{l}3 \mathrm{PWR} \\
\text { assemblies }\end{array}$ \\
\hline TN-9 & $\begin{array}{l}\text { Transnuclear, } \\
\text { Hawthorne, NY }\end{array}$ & USA/9016/B( )F & 79,200 & $\begin{array}{l}7 \text { cavities, } \\
-6 \text { in. } \times 6 \text { in. } \times 178 \text { in. }\end{array}$ & $\begin{array}{l}7 \mathrm{BWR} \\
\text { assemblies }\end{array}$ \\
\hline
\end{tabular}




\section{QUALITATIVE DECONTAMINATION AND DECOMMISSIONING DISCUSSION}

\subsection{INTRODUCTION}

The DOE facilities that will be used in the fabrication of MOX LAs have been used previously in the handling of nuclear materials. Because most of the facilities are contaminated to some degree, the MOX mission should have few incremental effects on the ultimate D\&D of these facilities. The intent of the FMDP is to decontaminate the facilities to levels that would permit unrestrictive further use of the facilities.

\subsection{PROCESS PLAN}

The development of a detailed D\&D plan will be necessary to minimize waste generation. Waste minimization during D\&D begins with the design of the MOX facility as discussed below. During the $D \& D$ phase, waste minimization measures would be similar to those required in the operation of any nuclear contamination zone. This includes reducing the number of items taken into a contamination zone to the minimum necessary to perform the job.

\subsection{D\&D OPERATIONS}

Because plutonium is primarily an alpha emitter, containment of contamination is a principle concern in the design and operation of a MOX plant. The process involves two distinctly different areas concerning contamination: (1) pellet fabrication where dusty powders of plutonium and uranium oxides are handled and (2) the rod and bundle assembly areas where little if any contamination should be present. At least $95 \%$ of the waste that will be generated during D\&D will be from the pellet fabrication area.

In the pellet fabrication area, a principle concern must be containment of the potential contamination from the copious quantities of plutonium and uranium dust that will be generated during operation of the dry processes. To minimize future D\&D costs, the containment of this potential contamination at its source of generation must be considered in the design of the MOX facility. This design should include local filtration at the source with no contamination allowed in the duct systems.

The rod and bundle assembly areas will use about $50 \%$ of the total space in the MOX facility and should be relatively contamination free. This space could be returned to beneficial occupancy soon after completion of the mission by simply removing the process equipment. Most of the uncontaminated rod and bundle assembly equipment will likely be useful in the full-scale MOX plant and could be shipped to that facility in the future.

Most of the waste generated during D\&D will come from the pellet fabrication area in the disassembly and disposal of contaminated process equipment items and excess glove boxes. The waste generated during D\&D, in addition to the contaminated equipment items and glove boxes, will be similar to the waste generated during operation of the MOX plant. This will consist of solid and liquid radioactive waste in similar types and volumes that will be generated during operations. The ratio of TRU to LLW likely will be higher during D\&D from the cleanup of the plutonium contamination in the glove boxes. The emissions during D\&D should be no more than during the operating phase of the LA MOX plant.

Complete decontamination probably will not be possible for most of the glove boxes and contaminated equipment items, and disposal as either LLW or TRU waste will be required. Most of the large equipment items and excess glove boxes likely will be packaged in large $B-25(4 \mathrm{ft} \times 4 \mathrm{ft} \times 6 \mathrm{ft})$ metal waste boxes. Size reduction of some equipment items and glove boxes likely will be required to fit within these boxes. The assay of the TRU content in some contaminated equipment items will be difficult to determine because of the difficulty of establishing calibration standards for the assay equipment. Also, the waste acceptance criteria for such "difficult to certify" TRU waste items for WIPP disposal have not been completely resolved by DOE. 
The equipment in the rod and bundle assembly areas either will not be contaminated or probably can be decontaminated to clean release standards for unrestricted use. The disposal of this equipment should present no particular problem. 


\section{PIE}

The two sites being considered for the PIE are Argonne National Laboratory-West (ANL-W) and ORNL. The facilities and infrastructure required to complete all PIE activities for the LA program currently exist at both sites. Accommodation of full-length fuel rods is the only modification required at ANL-W or ORNL to process the materials associated with this program. Both sites currently process equivalent materials to those expected in this program, and program activities will be routine.

Table 30 shows the wastes estimated during the LA PIE. Table 31 shows the possible employee radiation doses involved during PIEs of the LAs, and Table 32 lists the estimated PIEs for the EIS.

Figure 7 shows the location of Building 3525 on the ORNL site, and Fig. 4 shows the location of Building 785 on the ANL-W site. These buildings could be used to perform all PIE activities.

\subsection{PIE DISCUSSION}

PIE begins by shipping either the fuel assembly or the individual rods to the PIE facility. Shipment of selected individual rods is desired as it eliminates a handling step at the PIE facility (disassembly of the fuel assembly) and reduces the amount of irradiated fuel that needs to be handled (because only a fraction of the rods in a bundle is examined), stored, and disposed of at the hot cell.

Once the rods are in the hot cell at the PIE facility they are first subjected to a nondestructive examination. The degree of examination varies, but typically the rods are visually examined for signs of damage or wear, their length and diameter is measured, and individual rods may be weighed. After this simple check, additional examinations include eddy current or ultrasonic testing to locate cracks or flaws; leak testing to determine gas containment; gamma scanning to determine the internal fuel rod integrity, migration of fission products, and burnup; neutron radiography and $\mathrm{X}$-ray radiography to determine the internal physical configuration; and detailed visual examination of any crud or oxide layers on the surface of the clad. The particular techniques employed will depend on the program needs.

After the nondestructive testing has been satisfied, the destructive testing often begins by sampling the fission gas pressure and composition in the rod plenum by puncturing the end of the rod and collecting the gas. The rod may then be cut into segments for fuel examination. Thin sections of the rod are often cut off, mounted in epoxy resin, and polished for metallographic and ceramographic examinations. Additional portions of the fuel rod may be cut up for further fuel and clad examinations. Thin cross sections of the rod may be core drilled for fuel samples and the cores examined by gamma scanning or subjected to radiochemistry examination by dissolution in a chemical solution. The solution may undergo chemical analysis, gamma counting, and/or mass spectrometry for the determination of burnup and fission product composition.

Fuel specimens may undergo density measurements, pore size measurements, thermal diffusivity measurements, specific heat determination, melting point temperature estimation, oxygen to metal ratio measurements, and/or fission gas diffusivity depending on the degree of the investigation and the equipment available.

The rod cross sections may also be mounted in special mounts for examination by microprobe, optical microscope, transmission electron microscopy, and/or scanning electron microscope. Other techniques such as X-ray fluorescence and emission spectroscopy may be used depending on the needs of the investigation. These techniques allow the experimenter to determine the amounts and distribution of fission products, plutonium, uranium, and some trace elements. Such analyses allow the experimenter to compare the results of the irradiation with predictions and to investigate fuel behavior in considerable detail.

Clad specimens for mechanical testing may be prepared by segmenting the fuel rod and sliding the fuel out if possible, drilling the fuel out, or cutting and peeling the clad from the fuel. Once prepared, the clad may be subjected to a wide variety of tests such as tensile testing, burst testing, hardness testing, ductility testing, creep tests, fatigue testing, and chemical surface analysis.

All of these tests are considered to be normal PIE practices. The scope of the required equipment can be as simple as a small numbered scale to complex expensive shielded special purpose microscopes. Two references for PIE work are the Guidebook on Non-Destructive Examination of Water Reactor Fuel, IAEA 
Table 30. Estimated waste generated during the LA PIE

\begin{tabular}{|c|c|c|c|c|}
\hline Waste category & Annual volume & $\begin{array}{l}\text { Total estimated volume } \\
\text { (based on } 4 \text { years) }\end{array}$ & $\begin{array}{l}\text { Waste description } \\
\text { (e.g., glove box gloves, cleaning } \\
\text { solvent, paper wipes) }\end{array}$ & $\begin{array}{l}\text { Anticipated treatment and/or } \\
\text { disposal method (e.g., } \\
\text { solidification) } \\
\text { (specify on-site or off-site) }\end{array}$ \\
\hline $\begin{array}{l}\text { TRU } \\
\text { Liquid } \\
\text { Solid }\end{array}$ & $\begin{array}{l}107 \mathrm{~L}(28.2 \mathrm{gal}) \\
2.6 \mathrm{~m}^{3}\left(91.8 \mathrm{ft}^{3}\right)\end{array}$ & $\begin{array}{l}427 \mathrm{~L}(112.8 \mathrm{gal}) \\
10.4 \mathrm{~m}^{3}\left(367.3 \mathrm{ft}^{3}\right)\end{array}$ & $\begin{array}{l}\text { Paper wipes, plastic, glassware, metal } \\
\text { containers, fuel debris, clad pieces, } \\
\text { radiochemical solutions }\end{array}$ & $\begin{array}{l}\text { Solid material packaged in drums } \\
\text { for shipment to WIPP; liquids } \\
\text { processed on-site for later off-site } \\
\text { disposal as LLW }\end{array}$ \\
\hline $\begin{array}{l}\text { Mixed TRU } \\
\text { Liquid } \\
\text { Solid }\end{array}$ & $\begin{array}{l}1.08 \mathrm{~L}(0.29 \mathrm{gal}) \\
0.03 \mathrm{~m}^{3}\left(0.883 \mathrm{ft}^{3}\right)\end{array}$ & $\begin{array}{l}4.3 \mathrm{~L}(1.16 \mathrm{gal}) \\
0.1 \mathrm{~m}^{3}\left(3.53 \mathrm{ft}^{3}\right)\end{array}$ & $\begin{array}{l}\text { Oils, solvents, and lead shielding con- } \\
\text { taminated with TRU materials. }\end{array}$ & $\begin{array}{l}\text { Solid material will be packaged in } \\
\text { drums for shipment to WIPP; liq- } \\
\text { uids will be processed on-site for } \\
\text { later off-site disposal as LLW }\end{array}$ \\
\hline $\begin{array}{l}\text { LLWa } \\
\text { Liquid } \\
\text { Solid }\end{array}$ & $\begin{array}{l}107 \mathrm{~L}(28.2 \mathrm{gal}) \\
35 \mathrm{~m}^{3}\left(1236 \mathrm{ft}^{3}\right)\end{array}$ & $\begin{array}{l}427 \mathrm{~L}(112.8 \mathrm{gal}) \\
140 \mathrm{~m}^{3}\left(4944 \mathrm{ft}^{3}\right)\end{array}$ & $\begin{array}{l}\text { Paper wipes, plastic, glassware, metal } \\
\text { containers, clad pieces, equipment }\end{array}$ & $\begin{array}{l}\text { Material will be prepared on-site } \\
\text { for shipment to off-site facility }\end{array}$ \\
\hline $\begin{array}{l}\text { Mixed LLW } \\
\text { Liquid } \\
\text { Solid }\end{array}$ & $\begin{array}{l}1.08 \mathrm{~L}(0.29 \mathrm{gal}) \\
0.35 \mathrm{~m}^{3}\left(12.36 \mathrm{ft}^{3}\right)\end{array}$ & $\begin{array}{l}4.3 \mathrm{~L}(1.16 \mathrm{gal}) \\
1.4 \mathrm{~m}^{3}\left(49.4 \mathrm{ft}^{3}\right)\end{array}$ & $\begin{array}{l}\text { Oils, solvents, and lead shielding con- } \\
\text { taminated with fission products } \\
\text { materials }\end{array}$ & $\begin{array}{l}\text { Material will be sorted and pre- } \\
\text { pared on-site for shipment to off- } \\
\text { site facilities }\end{array}$ \\
\hline $\begin{array}{l}\text { Hazardous } c \\
\text { Liquid } \\
\text { Solid }\end{array}$ & $\begin{array}{l}1.08 \mathrm{~L}(0.29 \mathrm{gal}) \\
0.35 \mathrm{~m}^{3}\left(12.36 \mathrm{ft}^{3}\right)\end{array}$ & $\begin{array}{l}4.3 \mathrm{~L}(1.16 \mathrm{gal}) \\
1.4 \mathrm{~m}^{3}\left(49.4 \mathrm{ft}^{3}\right)\end{array}$ & $\begin{array}{l}\text { Used oils, solvents, resins, glues, } \\
\text { containers }\end{array}$ & $\begin{array}{l}\text { Material will be sorted and pre- } \\
\text { pared on-site for shipment to off- } \\
\text { site facilities }\end{array}$ \\
\hline $\begin{array}{l}\text { Nonhazardous (sanitary) } \\
\text { Liquid } \\
\text { Solid }\end{array}$ & $\begin{array}{l}3.79 \times 10^{5} \mathrm{~L}\left(1.0 \times 10^{5} \mathrm{gal}\right) \\
50 \mathrm{~m}^{3}\left(1765 \mathrm{ft}^{3}\right)\end{array}$ & $\begin{array}{l}1.51 \times 10^{6} \mathrm{~L}\left(4 \times 10^{5} \mathrm{gal}\right) \\
130 \mathrm{~m}^{3}\left(4591 \mathrm{ft}^{3}\right)\end{array}$ & $\begin{array}{l}\text { Potable water, cleaning, paper, plastic, } \\
\text { metal containers, garbage }\end{array}$ & $\begin{array}{l}\text { Materials will be disposed of } \\
\text { through laboratory (on-site) non- } \\
\text { hazardous waste facility }\end{array}$ \\
\hline $\begin{array}{l}\text { Nonhazardous (other) } \\
\text { specific by waste } \\
\text { Liquid } \\
\text { Solid }\end{array}$ & $\begin{array}{l}4 \mathrm{~L}(1.06 \mathrm{gal}) \\
0.75 \mathrm{~m}^{3}\left(26.48 \mathrm{ft}^{3}\right)\end{array}$ & $\begin{array}{l}16 \mathrm{~L}(4.23 \mathrm{gal}) \\
3 \mathrm{~m}^{3}\left(106 \mathrm{ft}^{3}\right)\end{array}$ & $\begin{array}{l}\text { Chemical reagents, oils, cleaners, scrap } \\
\text { metal, wood, plastic }\end{array}$ & $\begin{array}{l}\text { Materials will be disposed through } \\
\text { laboratory (on-site) nonhazardous } \\
\text { waste facility. Scrap may be dis- } \\
\text { posed of through the laboratory to } \\
\text { off-site vendors }\end{array}$ \\
\hline
\end{tabular}

Note: Estimates are based on historical experience from other programs and current operations. The actual waste stream will be strongly dependent on the type and amount of work performed. The actual waste handling will depend on the laboratory facilities in operation at the time and the current disposal regulations. The final volumes of waste will be smaller depending on the treatment option (drying, compacting, burning).

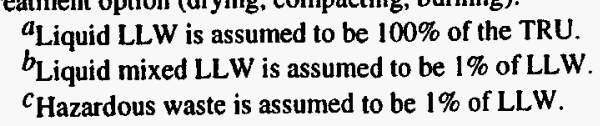


Table 31. Radiation doses to involved workers during the LA PIE [whole body committed effective dose equivalent (CEDE)]

Average annual dose to all involved workers at the facility, mrem 177

Maximum dose to an involved worker at the facility, mrem 347

Total number of involved workers

Note: Table numbers are averages over 1994, 1995, and 1996 for Building 3525 at ORNL. Values are from the radiation protection representative. It is assumed that the MOX PIE will encounter similar exposures.

Table 32. PIE estimates for EIS

\begin{tabular}{|c|c|c|}
\hline & \\
\hline & & 289 rods total \\
\hline \multicolumn{2}{|l|}{$\begin{array}{l}\text { For planning purposes assume } 17 \text { by } 17 \text { fuel bundle array } \\
\text { Bundle length }\end{array}$} & $13.50 \mathrm{ft}$ \\
\hline \multicolumn{2}{|l|}{ Pellet size } & $\begin{array}{l}0.37 \text {-in. diam, } \\
0.60 \text {-in. length, } \\
0.06 \text {-in. }{ }^{3} \text { volum }\end{array}$ \\
\hline \multicolumn{2}{|l|}{ Approximate density $\mathrm{UO}_{2}+\mathrm{PuO}_{2}$} & $11.00 \mathrm{~g} / \mathrm{cm}^{3}$ \\
\hline \multicolumn{2}{|l|}{ Mass of pellet } & $11.43 \mathrm{~g}$ \\
\hline \multicolumn{2}{|l|}{ Mass of pellet HM } & $10.08 \mathrm{~g}$ \\
\hline \multicolumn{2}{|l|}{ Pellets per rod } & 270.00 \\
\hline \multicolumn{2}{|l|}{ Pellet mass per rod } & $3087 \mathrm{~g}$ \\
\hline \multicolumn{2}{|l|}{ HM per rod } & $2721 \mathrm{~g}$ \\
\hline \multicolumn{2}{|l|}{$\begin{array}{l}\text { Assume detailed PIE will involve ten rods per bundle and } \\
\text { ten bundles }\end{array}$} & 100 rods to be $\mathrm{cl}$ \\
\hline \multicolumn{2}{|l|}{ Estimated samples per rod } & 10 \\
\hline \multicolumn{2}{|l|}{ Total samples } & 1000 \\
\hline \multicolumn{2}{|l|}{ Assume one-third metal mounts } & 333 \\
\hline \multicolumn{2}{|l|}{ Assume one-third clad specimens } & 333 \\
\hline \multicolumn{2}{|l|}{ Assume one-third radiochemical specimens } & 333 \\
\hline \multicolumn{2}{|l|}{ Liquid waste per metal mount } & $\begin{array}{l}167 \mathrm{~L} \text { total for } \\
\text { metal mounts }\end{array}$ \\
\hline Liquid waste per clad specimen & $0.1 \mathrm{~L}$ & $\begin{array}{l}33 \mathrm{~L} \text { total for } \\
\text { clad specimen }\end{array}$ \\
\hline Liquid waste per radiochemical specimens & $1 \mathrm{~L}$ & $\begin{array}{l}33 \mathrm{~L} \text { total for } \\
\text { radiochemical }\end{array}$ \\
\hline \multicolumn{2}{|l|}{ Total specimen liquid waste (TRU) } & $533 \mathrm{~L}$ \\
\hline Solid waste per metal mount and all mounts & $200 \mathrm{~cm}^{3}$ & $0.07 \mathrm{~m}^{3}$ total \\
\hline Solid waste per clad specimen and all clad specimens & $200 \mathrm{~cm}^{3}$ & $0.07 \mathrm{~m}^{3}$ total \\
\hline Solid waste per radiochemical specimen and all specimens & $500 \mathrm{~cm}^{3}$ & $0.17 \mathrm{~m}^{3}$ total \\
\hline Total specimen solid waste (TRU) & & $0.30 \mathrm{~m}^{3}$ \\
\hline Assume two B- 25 boxes of equipment & & $6 \mathrm{~m}^{3}$ \\
\hline One-half equipment LLW & & $3 \mathrm{~m}^{3}$ \\
\hline One-half equipment TRU & & $3 \mathrm{~m}^{3}$ \\
\hline Assume one $\mathrm{B}-25$ box per month $/ 48$ months & & $144 \mathrm{~m}^{3}$ \\
\hline $\begin{array}{l}0.9 \text { LLW [personal protective equipment (PPE), wipes, } \\
\text { scrap, etc.] }\end{array}$ & & $130 \mathrm{~m}^{3}$ \\
\hline $0.1 \mathrm{TRU}$ & & $14 \mathrm{~m}^{3}$ \\
\hline Total liquid TRU waste & & $533 \mathrm{~L}$ \\
\hline Total solid TRU waste & & $18 \mathrm{~m}^{3}$ \\
\hline
\end{tabular}


Table 32. (continued)

Total mixed liquid TRU waste

Total mixed solid TRU waste

Total liquid LLW

Total solid LLW

Total mixed liquid LLW

Total mixed solid LLW

Other waste streams

Liquid hazardous waste

Solid hazardous waste

Nonhazardous liquid waste

Nonhazardous solid waste

Nonhazardous liquid other waste-chemicals

Nonhazardous solid other waste-scrap metal, one B-25 box
$5 \mathrm{~L}$ (estimated as $1 \%$ of TRU)

$0.18 \mathrm{~m}^{3}$ (estimated as $1 \%$ of TRU)

$533 \mathrm{~L}$ (estimated same as TRU)

$133 \mathrm{~m}^{3}$

$5 \mathrm{~L}$ (estimated as $1 \%$ of LLW)

$1 \mathrm{~m}^{3}$ (estimated as $1 \%$ of LLW)

$5 \mathrm{~L}$ (estimated as $1 \%$ of LLW)

$1 \mathrm{~m}^{3}$ (estimated as $1 \%$ of LLW)

$533 \mathrm{~L}$ (estimated as 100\% LLW)

$133 \mathrm{~m}^{3}$ (estimated as $100 \%$ of LLW)

$5 \mathrm{~L}$ (estimated as $1 \%$ of LLW) $3 \mathrm{~m}^{3}$

Assume that bulk of the fuel rods and fuel bundle will be handled as spent nuclear fuel and sent to Idaho National Engineering and Environmental Laboratory 


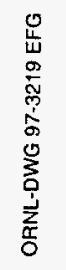

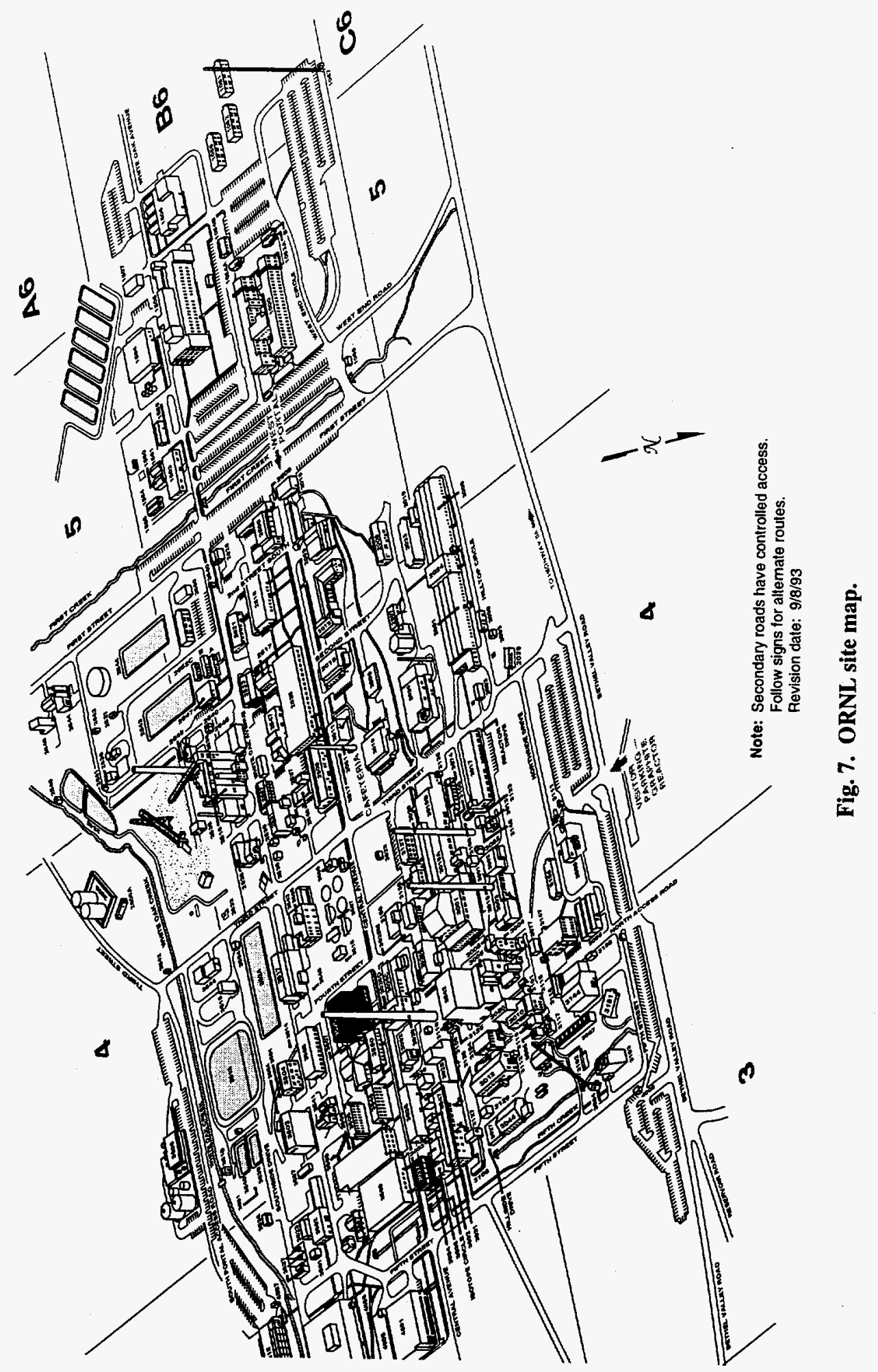


Technical Reports Series No. 322; and the Guidebook on Destructive Examination of Water Reactor Fuel, IAEA Technical Reports Series No. 385.

In addition to materials testing, the segmented fuel may be used as a test subject for accident testing. The segment may be heated to high temperatures in a variety of atmospheres in a complex test apparatus and its releases measured. Other specialized methods also exist; irradiated material may be removed from one experiment and transferred to another in the hot cell for further irradiation.

The fuel rods in the MOX program will employ nondestructive examination as well as many of the destructive techniques. Normal practice is rather broad, and the actual techniques and items of interest will be determined before PIE and will depend on the program's knowledge and confidence level at the time.

\subsection{ANL-W}

The Hot Fuel Examination Facility (HFEF) is a hot-cell complex for the preparation and examination of irradiated experiments and the characterization and testing of waste forms from conditioning of spent fuel and waste. The HFEF is located on the ANL-W site, which is located in the south-west corner of INEEL. The HFEF facility is located on the north end of a double-fenced compound on the ANL-W site.

HFEF consists of two adjacent shielded hot cells (the main and decon cells), a shielded metallographic loading box, an unshielded Hot Repair Area (HRA) and a Waste Characterization Area (WCA). The building is a three-story structure with a basement support area. The building dimensions are $112 \mathrm{ft}$ wide by $154 \mathrm{ft}$ long with a gross floor area of $56,570 \mathrm{ft}^{2}$ and a gross volume of $1,337,200 \mathrm{ft}^{3}$.

The metallographic loading box is located outside the main cell in the metallograph room. This room is located on the north side of the building on the main floor and is separated from the main cell by an operating corridor.

The HRA and WCA are located in the high bay area. The area provides access to the ceiling penetrations in the main and decon cells as well as the HRA roof hatch. The high bay is also used as a staging area for the WCA.

Since the shutdown and defueling of the EBR-II reactor, HFEF has been used for many diverse programs. The primary program, since October 1994, has been the support of the EBR-II defueling and decommissioning. HFEF was responsible for receiving all of the fuel and blanket material from EBR-II and preparing the material for storage in the Radioactive Scrap and Waste Facility (RSWF).

In addition to the handling of the EBR-II fuel, HFEF is the examination facility for both the metal and ceramic waste form experiments from FCF. Cladding hulls from the conditioning of fuel in FCF need to be processed for disposal in a repository. The processing of the cladding hulls and the characterization of the waste form is being tested in HFEF. In addition, equipment is being installed and processes tested for the disposal of the plutonium and fission product waste from the conditioning of EBR-II fuel. The testing and characterization of the ceramic waste forms will be performed in HFEF.

HFEF is presently starting facility modification to accept commercial-sized fuel assemblies from the Watts Bar reactor. These assemblies (specifically, tritium production burnable absorber rods) are the initial assemblies being irradiated as part of DOE's commercial LWR tritium production evaluation. All of the examination equipment in the cell and the cask handling systems are being modified to handle commercialsized casks and fuel rods for examination. These modifications will be complete in mid-1999.

Some of the stainless steel reflector subassemblies used in EBR-II have experienced neutron exposure since the reactor was started in the early 1960s. The neutron damage to these steels is of interest to the commercial power industry, especially in Japan. Two programs are in place where the stainless steels are being prepared for testing of the neutron damage. These programs involve the cutting and preparation of samples for testing at other laboratories.

The north neutron radiography station has been modified to house a neutron generator for neutron assay of waste. Testing is presently being done on developing neutron assay techniques for the waste from the FCF.

In support of the National Spent Fuel Program, HFEF is presently engaged in the examination of degraded EBR-II fuels that have been stored in water pools at the ICPP. The fuel was shipped to ICPP in sealed containers. During the 15 to 20 years of storage in the water basin at ICPP, some of the containers 
have leaked, causing the fuel to breach. The characterization and examination of the degraded fuel at the HFEF will determine the chemical condition of the fuel as well as the mechanism for breaching. This program will be ongoing during the next 2 years.

\subsubsection{Main Cell}

The HFEF main cell is $70 \mathrm{ft}$ long by $30 \mathrm{ft}$ wide by $25 \mathrm{ft}$ high and has an argon gas atmosphere. The argon gas in the cell is maintained as pure as possible; however, a small amount of moisture is needed to help lubricate and cool the brushes on the electric motors used in cell. Because of this, the moisture and oxygen levels are maintained about $40 \mathrm{ppm}$. The maximum oxygen and moisture levels are kept below 100 $\mathrm{ppm}$. The cell atmosphere is maintained at these levels using a purification system.

An 8-ft deep space that is located beneath removable flooring and covers the entire width of the cell is used for storage of fuel elements during their examination. Also located in this space are the bases of the examination stages, ducts and filters for the main cell cooling system, and pits for the storage of radioactive materials. A total of ten 1-ft diam by 10-ft long storage pipes are located in the center aisle of the cell for storage of Experimental Breeder Reactor-II (EBR-II) subassemblies. These pits are equipped with forced argon cooling for decay heat removal of their contents.

In addition to the subfloor space, two 3-ft diam pits extend $30 \mathrm{ft}$ below the level of the removable floor at workstations $8 \mathrm{M}$ and $9 \mathrm{M}$ (south-east corner of the cell). These pits are used for storing and handling of long items such as long test loops. Each pit has a corresponding roof penetration so long items can be transferred into the cell and placed in a pit.

The main cell is serviced by two electro-mechanical manipulators (EMMs) rated for $750 \mathrm{lb}$ and two 5-ton bridge cranes. The maximum lift for an EMM in the main cell is $11 \mathrm{ft} 8 \mathrm{in}$. The maximum lift for a crane in the cell is $19 \mathrm{ft} 11-5 / 8 \mathrm{in}$.

There are 15 workstations in the main cell. Each workstation is equipped with two master/slave (MS) manipulators. Most of the MS manipulators are Central Research Laboratory (CRL) Model J's rated for a 20-lb vertical lift. Five of the workstations are equipped with CRL System 50 manipulators rated for a 50-1b vertical lift.

\subsubsection{Decon Cell}

The air-filled decon cell is located adjacent to the west end of the main cell and is $30 \mathrm{ft}$ wide by $20 \mathrm{ft}$ long by $25 \mathrm{ft}$ high. There is no subfloor space in the decon cell; however, three 15.5 -in. diam by 10 - $\mathrm{ft}$ deep pits are located at workstation 3D. Another similar pit is located at workstation $4 \mathrm{D}$, and a $3-\mathrm{ft}$ diam by $30-\mathrm{ft}$ deep pit is located at workstation $5 \mathrm{D}$.

The decon cell is equipped with an 8 -ft wide by 7 -ft deep by 11 -ft high spray chamber for decontaminating equipment and nonfissile material using a manipulator-held wand. The wand can be used for spraying either water or steam. A chemical addition tank is connected to the water feed line for the addition of decontamination solutions to the water stream. Items being decontaminated are positioned on a 5-ton turntable inside the chamber so that they can be rotated. Both the roof and back side of the spray chamber can be opened remotely so items being decontaminated can be placed inside the chamber.

Material handling inside the decon cell is performed with one 750-lb EMM and one 5-ton crane. The maximum lifting height of the EMM is $11 \mathrm{ft} 8 \mathrm{in}$. and that of the crane is $19 \mathrm{ft} 11 \mathrm{in}$. In addition to the EMM and crane, the cell is equipped with six sets of MS manipulators. Most of the workstations are equipped with one CRL model E MS, rated for a 20-lb vertical lift, and one CRL model F MS, rated for a $100-$ lb vertical lift.

Two pneumatic transfer stations are inside the decon cell. One station originates at station 4D and runs to the Fuel Conditioning Facility (FCF). The other station originates inside the spray chamber and runs to the radiation safety office (HP office). The pneumatic transfer station that runs to FCF is used for sending small irradiated samples to FCF then on to the Analytical Laboratory (AL) for analysis. 


\subsubsection{Metallographic Loading Box}

The metallographic loading cell is a shielded, gas-tight cell with inside dimensions of $8 \mathrm{ft}$ wide by $6 \mathrm{ft}$ deep by $5 \mathrm{ft}$ high. The cell is provided to accommodate a Leitz metallograph and a scanning electron microscope (SEM) for performing detailed examination of metallurgical samples. The shielding walls (except the front wall) are constructed of 8-in.-thick lead brick. The front wall is 15 -in. thick and is constructed of three 5-in.-thick steel plates. The front wall has a lead-glass window for viewing and two CRL Model L MS manipulators.

\subsubsection{HRA}

The HRA is a series of rooms located directly above the decon cell and west end of the main cell in the high bay area. The outside dimensions of the HRA are $45 \mathrm{ft}$ by $70 \mathrm{ft}$. The primary purpose of the HRA is to perform contact maintenance on cell equipment. The HRA is divided into 12 areas:

1. Hot Repair Room (HRR)

2. Suspect Repair Room

3. Equipment Access Room (Cart Room)

4. Isolation Area Room

5. Survey Room

6. Health Physics (HP) Office

7. Unsealed Slave Repair Room

8. Bagout Room

9. Sealed Slave Arm Repair Glove Box Room

10. Stepout Area Room

11. Glovewall Room

12. Ancillary Area Room

Most of the rooms in the HRA are specific-purpose rooms used for the repair of MS manipulators and other facility-specific equipment. The HRR can be used for the transfer of equipment and materials between the decon cell and HRA. Both the HRR and Suspect Repair Room are serviced by a 5-ton bridge crane. The crane uses a removable rotating hook for remote positioning of the hook. With the rotating hook removed, the maximum lift inside the repair rooms is $13 \mathrm{ft} 6 \mathrm{in}$. With the hook in place the maximum lift inside the HRR is $12 \mathrm{ft} 1 \mathrm{in}$. The drum on the crane is provided with enough cable for a 50 - $\mathrm{ft}$ lift so that it can be used for raising and lowering equipment into the decon cell.

A $10 \mathrm{ft}^{2}$ roof hatch is located in the ceiling of the HRR, directly above the decon cell roof hatch. The hatch is provided with a 114-in. diam bagging ring so it can be used for the transfer of equipment and material directly from the high bay area into the decon cell.

The equipment access room (cart room) is designed to be a lock in the transfer path between the high bay area and the HRR. The room is $8 \mathrm{ft}^{2}$ by $20 \mathrm{ft}$ high and has a $6 \mathrm{ft} 4$ in. ${ }^{2}$ hatch in the ceiling. The room is generally maintained clean so equipment and materials can be transferred from the high bay area to the room through the hatch. A 5-ton equipment cart runs between the cart room and the HRR for moving the equipment and materials between the two rooms.

\subsubsection{WCA}

The WCA is used for the characterization and sampling of contact-handled transuranic waste ( $\mathrm{CH}$ TRU) for the Waste Isolation Pilot Plant (WIPP) performance assessment. The facility consists of the Preparation Room, Transfer Room, Waste Characterization Chamber (WCC), Sludge Preparation glove box, Operations Room and the Equipment Room.

The Preparation Room (PR) is used as a staging area for waste going into and out of the WCC. Waste drums awaiting characterization in the WCC are stored in the PR, and waste that has been characterized and is awaiting shipment back to the Radioactive Waste Management Complex (RWMC) is also stored in the room. Personnel access to the PR is through a vestibule on the south-east corner of the room. Waste 
drums and equipment are brought into the room using the high bay crane through a $10-\mathrm{ft}$ high by $8-\mathrm{ft}$ wide equipment door on the south wall. High bay crane hook access to the room is through a 2 -ft wide by 17-ft-long rollup door on the vertical wall and ceiling above the equipment door. Waste drums and equipment are handled inside the PR by a cantilever-style jib crane rated for a $6000 \mathrm{lb}$ SWL. The crane has a lift height of $12 \mathrm{ft} 8 \mathrm{in}$.

The Transfer Room (TR) is where the waste drums are mated with the WCC. Access to the room is through double doors from the PR. The drums are moved into and out of the TR using a drum cart rated at $2,000 \mathrm{lb} \mathrm{SWL}$. In addition to moving the drums into and out of the room, the cart is used to raise and lower the drums to the drum ports on the bottom of the WCC. Once the drums are bagged to the WCC, they are held in position in the drum ports by turnbuckles which fasten between the bottom of the WCC and an adapter plate under the drums.

The WCC is a 16-ft long by $8-\mathrm{ft}$ high by 8 - $\mathrm{ft}$ deep glove box used for characterization of $\mathrm{CH}$ TRU wastes. The WCC is equipped with shielded viewing windows for personnel protection from low-level gamma and beta radiation. Each window is a three-piece assembly consisting of an inner safety glass, a lexan plate, and leaded glass on the exterior. There are two 200-lb dual Titan 7F manipulators and a $1,500-\mathrm{lb}$ articulated jib crane for handling the waste and equipment inside the glove box. A core boring machine is mounted to the top of the glove box over the west drum port and is used for taking samples from sludge drums. There are 28 glove ports on the WCC. These glove ports are located at various heights for waste handling and equipment repair. A transfer port is located on the east end of the WCC for transferring sludge samples to the Sample Preparation glove box.

The Equipment Room (ER) is located above the WCC and houses the filters, piping, and blowers for the WCC ventilation system. In addition to the ventilation equipment, the ER has a repair glove box for repair of the equipment inside the WCC. The glove box is connected to the west end of the WCC through a transfer tunnel. Equipment is raised and lowered from the repair glove box by a hoist inside the glove box.

The Operations Room (OR) is the area around the WCC and Sample Preparation and Transfer glove boxes. The room provides a mezzanine on the west end of the WCC for the Waste Data Acquisition System (WDAS). The WDAS is used for video taping and audio dubbing of the waste handling operations. A computer controlled switcher is used for switching video sources and recorders. The computer control system for the gas sampling system is mounted on the south end of the WDAS.

In addition to the WDAS, the OR provides monitoring and alarm panels for monitoring the status of the WCA. The panel provides flow and pressure information on the WCC, radiation alarms, breathing air alarms, and fire alarms for the inside of the WCC.

The sludge preparation (SP) glove box is used for preparing sludge samples for shipment to the Idaho Chemical Processing Plant (ICPP) to be analyzed for halogenated VOCs, nonhalogenated VOCs, RCRA heavy metals, and radioassay. After the sludge has been cored, the core section is transferred to the SP glove box where the samples are taken at various locations along the core section. As each sample is taken, it is weighed, placed in a labeled vial, and shipped to ICPP in a Type A container. Some experimentation is being done on real time analysis of the samples using $\mathrm{X}$-ray florescence. The testing of the equipment has not been completed.

\subsection{ORNL}

The Irradiated Fuels Examination Laboratory (IFEL), Building 3525, has a long history of fuel research and examination. It is part of ORNL and is located in Bethel Valley and Melton Valley, approximately 8 miles southwest of the city of Oak Ridge, Tennessee. For three decades this facility has handled a wide variety of fuels including aluminum clad research reactor fuel, both stainless- and zircaloyclad LWR fuel, coated-particle gas cooled reactor fuel, and numerous one of a kind fuel test specimens. In addition, the facility has also done iridium isotope processing and irradiated capsule disassembly.

The IFEL contains a large horseshoe-shaped array of hot cells which are divided into three work areas (Fig. 8). The hot cells are constructed of 3-ft-thick concrete walls with oil-filled, lead-glass viewing windows. The inside of surfaces of the cell bank are lined with stainless steel to provide containment of particulate matter and to facilitate decontamination. Special penetrations are provided for the sealed entry of services such as instrument lines, lights, and electrical power. A pair of manipulators are located at each 


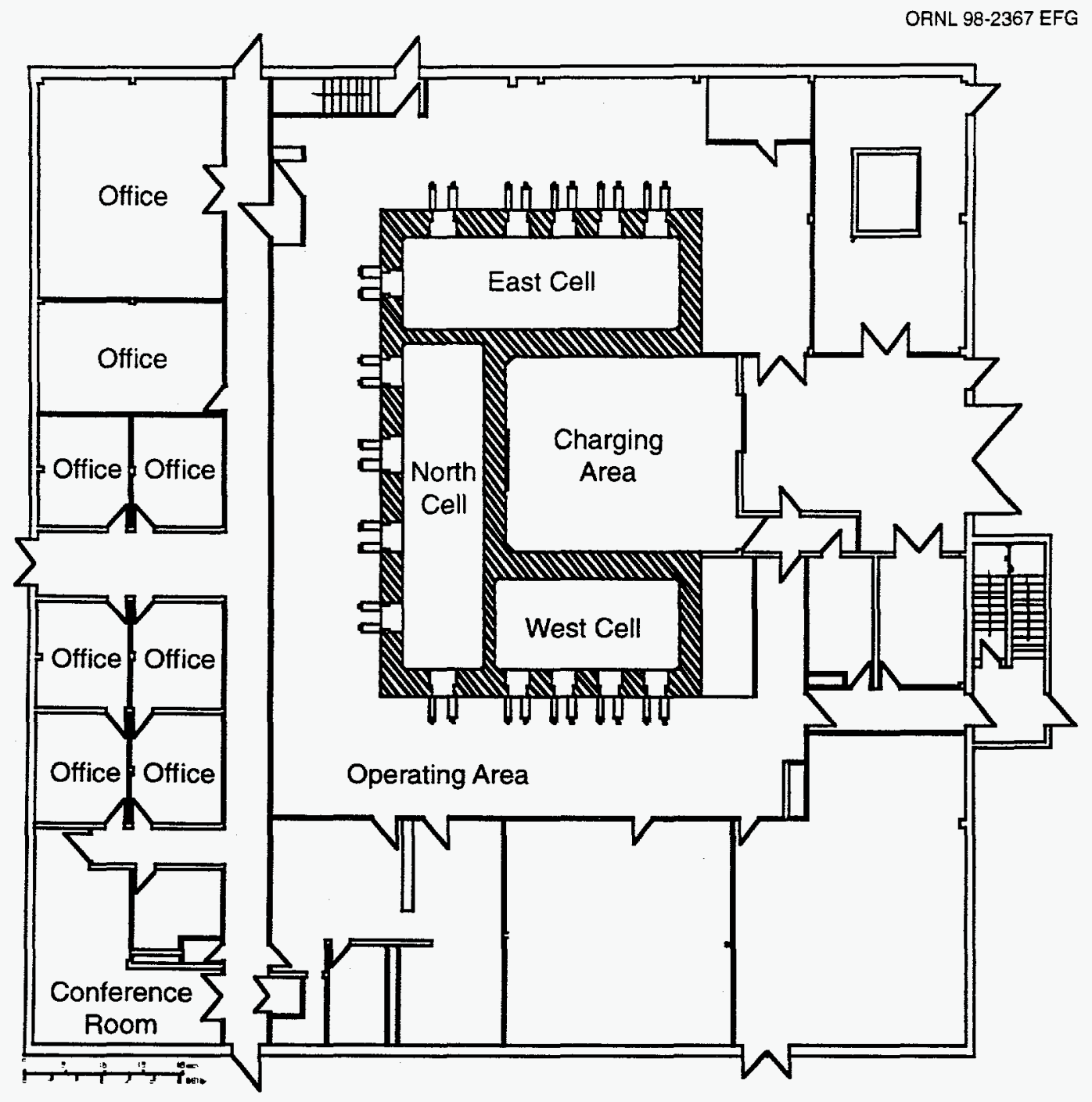

Fig. 8. Building 3525 layout.

of 15 window stations for remote cell operations, and periscopes allow for magnified views of in-cell objects. Heavy objects within each cell bank can be moved by electromechanical manipulators or a 3-ton crane. Fuel materials enter and leave the cells through three shielded transfer stations provided at the rear face of the North cell. Two small diameter (6.5 and 14.5 in.) horizontal transfer stations are used for small objects (less than $8 \mathrm{ft}$ in length). Items up to $4 \times 4 \times 6 \mathrm{ft}$ in size can be transferred through the shielded airlock door system.

The remainder of the laboratory outside the hot cell complex is subdivided into: (1) the charging area; (2) the equipment maintenance air lock areas; (3) the operating area; (4) the truck unloading area, the change room, and a work room; and (5) the rooms housing supporting mechanical equipment. Located on the east side of the truck unloading area is a small laboratory which houses the Core Conduction Cooldown Test Facility (CCCTF). The CCCTF is used to test radioactive samples under controlled thermal conditions while monitoring the samples to determine the release rate of radioactive materials.

A decontamination cell and storage cell, located on the second floor of the building, are connected via hatches to the cells below. A maintenance area incorporating glove box facilities for servicing equipment items adjoins the decontamination cell. Sliding doors separate the decontamination cell, storage cell, and glove maintenance room; a remote crane system provides for retrieval of equipment into and transfer of 
items between these second-floor facilities. Equipment may be transferred between cells through the second-floor pathway. An upper level of the second floor houses ventilation system ducts, control valves, high efficiency particulate air filters, heat exchangers, and air inlets for the equipment storage area, the decontamination area, and the glove maintenance area.

Gases and particulates exhausted from the cell complex are completely contained and shielded until subjected to sufficient filtration to ensure safe stack disposal. The cell air is maintained at negative pressure with respect to the operating areas to ensure confinement. Liquid effluent from the hot cells is handled in a batch mode for disposal to the ORNL low-level liquid waste system.

A variety of shears, machine tools, and cutoff saws are available within the cell for the gross handling and preparation of fuel specimens. The facility has experience in the handling and cutting of a wide variety of capsule and clad materials such as Inconel, stainless steel, zircaloy, aluminum matrix, and graphite-based materials. A gamma scanner is available for the nondestructive examination of moderate-length fuel rods and individual specimens. Metrology equipment such as mass scales and dimensional tools are routinely used and available.

Metallographic equipment including small cutoff saws, polishers, and a shielded metallograph are available for the preparation, handling, and examination of both fuel specimens and clad material. The facility has prepared samples of oxide fuels, carbide fuels, and metal matrix fuels.

Building 3525 also has other facilities outside the main bank of cells: a scanning electron microscope that can handle radioactive specimens, additional gamma analysis and dosimetry equipment for both centimeter-sized and submillimeter-sized samples, and a small stand-alone hot cell with specialized equipment for the handling and analysis of coated-particle fuels.

Radiochemical specimens can be prepared within the facility and delivered to other ORNL laboratories for detailed analysis. ORNL also has extensive computational abilities that can be used to process the hot cell data for comparison with fuel performance models.

PIE capabilities of the IFEL have provided general support to fuels program, fuel characterization, and analysis of candidate irradiated fuel. Typically, the fuel is received at the IFEL, dimensionally inspected, visually examined for defects, and gamma scanned for internal fuel gaps or cracks along with gross fission product migration. The fuel can then be removed from its casing or clad and fuel and clad specimens prepared for metallographic examination, gamma counting, and radiochemical analysis. Actinide and fission product inventories can be determined along with burnup and radial isotope distributions within the fuel. The mechanical properties of the specimens can also be investigated to determine the state of the fuel and/or clad materials. All work is typically done with proper procedures and documentation after concurrence is obtained from the program participants.

Recent work includes extensive support for the Gas Turbine Modular. High-Temperature Gas-Cooled Reactor (GT-MHR) program, the New Production Reactor (NPR), a cooperative gas-cooled reactor agreement with Japan, and handling of legacy fuel under the National Spent Fuel program. Personnel are available with experience in a wide variety of fuel PIE programs and analysis techniques along with the detailed reporting and quality control requirements for nuclear programs. The Metals and Ceramics (M\&C) division contains a wealth of experience in fuel fabrication, metal and ceramic material behavior, irradiated material behavior, and material testing. Ongoing programs at ORNL maintain experience in hot cell techniques and analysis. In addition, academic and industrial consultants are available to meet special program needs and to conduct reviews. 
Page Intentionally Blank 


\section{REFERENCES}

1. U.S. Department of Energy, Storage and Disposition of Weapons-Usable Fissile Materials Final Programmatic Environmental Impact Statement, Vol. 1, Chap. 3, DOE/EIS-0229, December 1996.

2. Los Alamos National Laboratory, Response to the Surplus Plutonium Disposition Environmental Impact Statement Data Call for a Mixed Oxide Fuel Fabrication Facility Located at Pantex Plant, LA-UR97-2067, Rev. 3, June 22, 1998.

3. V. S. White, Initial Data Report and Response to the Surplus Plutonium Disposition Environmental Impact Statement Data Call for the UO 2 Supply, ORNL/TM-13466, Lockheed Martin Energy Research Corporation, Oak Ridge National-Laboratory, November 1997.

4. Shearon Harris Nuclear Power Plant Technical Specifications, Sect. 3.8.

5. U.S. Department of Energy, Airborne Release Fractions/Rates and Respirable Fractions for Nonreactor Nuclear Facilities, DOE-HDBK-3010-94, Vols. I and II, December 1994.

6. Browne and Firestone, Table of Radioactive Isotopes, V. S. Shirley, ed., John Wiley and Sons, 1986.

7. U.S. Department of Energy, Criteria for Preparing and Packaging Plutonium Metals and Oxides for Long-Term Storage, DOE-STD-3013-96, September 1996.

8. DOE Order 420.1, Sect. 4.3, Nuclear Criticality Safety.

9. 40 CFR 302.4, Table 302.4, List of Hazardous Substances and Reportable Quantities.

10. W. R. Stratton, A Review of Criticality Accidents, DOE/NCT-04, March 1989. 
APPENDIX A-LA FUEL BUNDLE FABRICATION

A-1 
Page Intentionally Blank

A-2 
$\mathrm{PuO}_{2}$

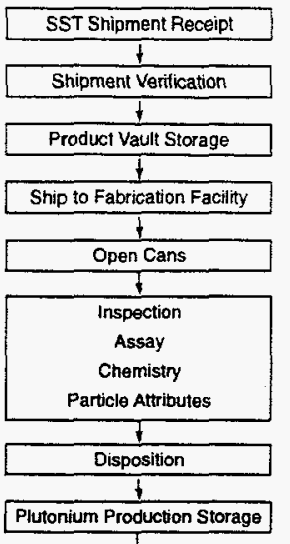

Depleted $\mathrm{UO}_{2}$

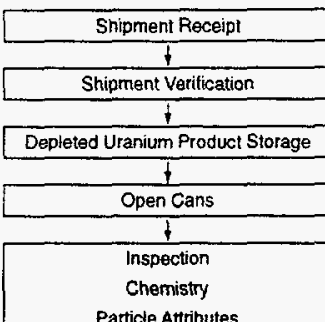

Particle Atributes

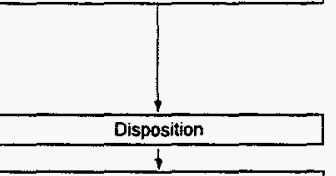

Depleted Uranium Production Storage

Hard Scrap Recycle

(Depleted Uranium/Plutonium)

(Up To 10\% Of Batch Makeup)

From Sintered Pellet Scrap

Weigh

Storage

Crush (Jaw Crusher)

I

Grind (Bail Mill)

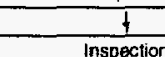

Inspection

Chemistry

Particle Attributes

UraniumvPlutonium Ratio

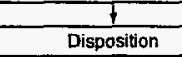

Dispositjon

Recycle Production Storage (30\% Plutonium) Powder

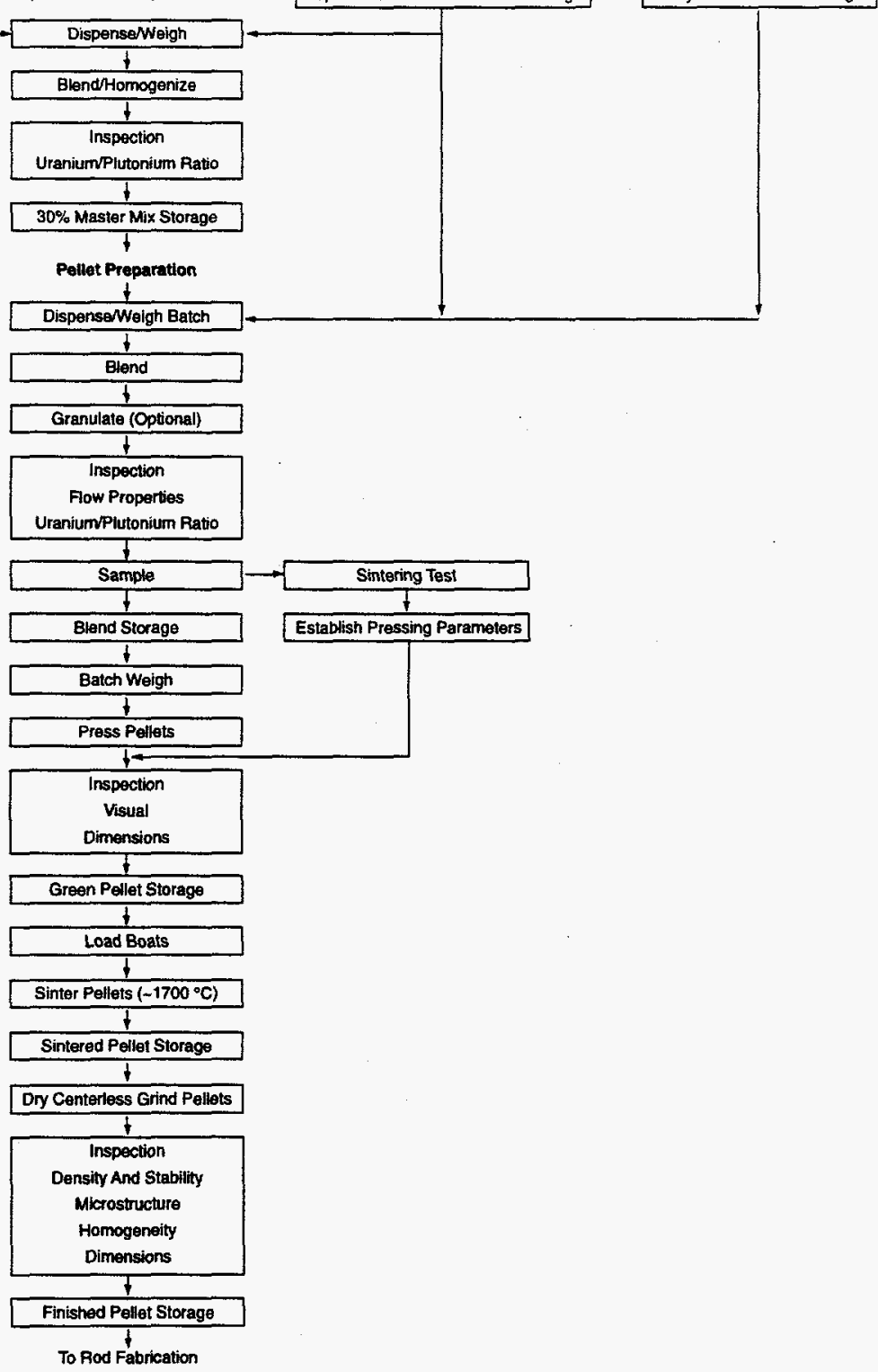

Fig. A.1. LA MOX fuel pellet flow sheet outline. 


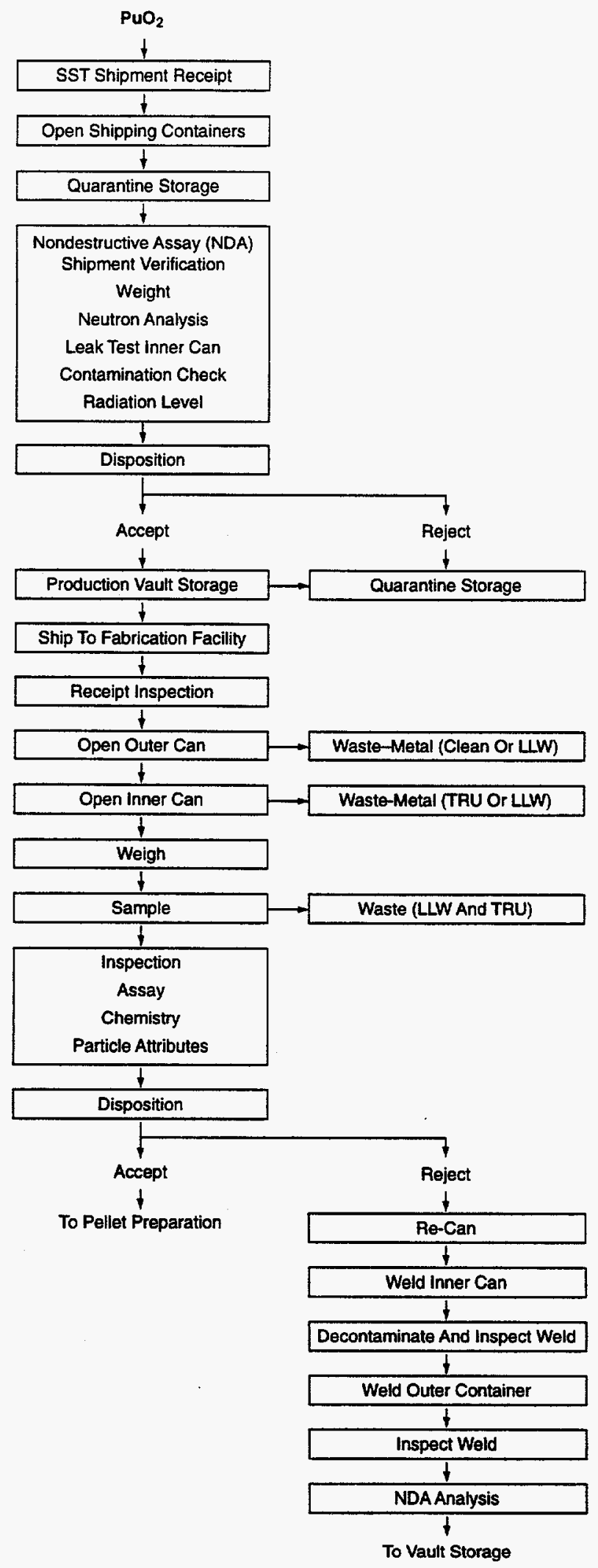

Fig. A.2. $\mathrm{LA}$ MOX fuel $\mathrm{PuO}_{2}$ powder receipt and storage. 


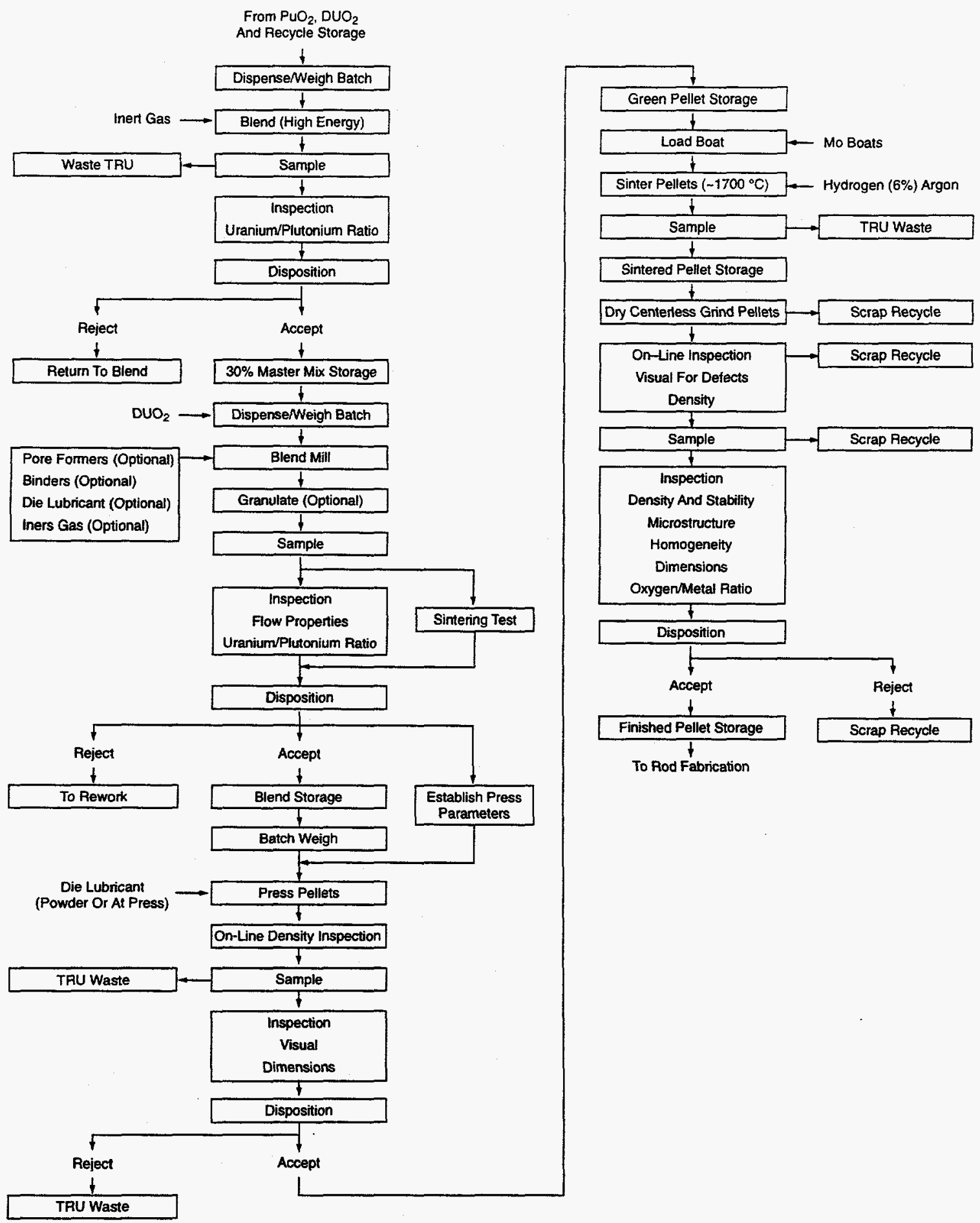

Fig. A.3. Detailed flow sheet of LA pellet fabrication. 


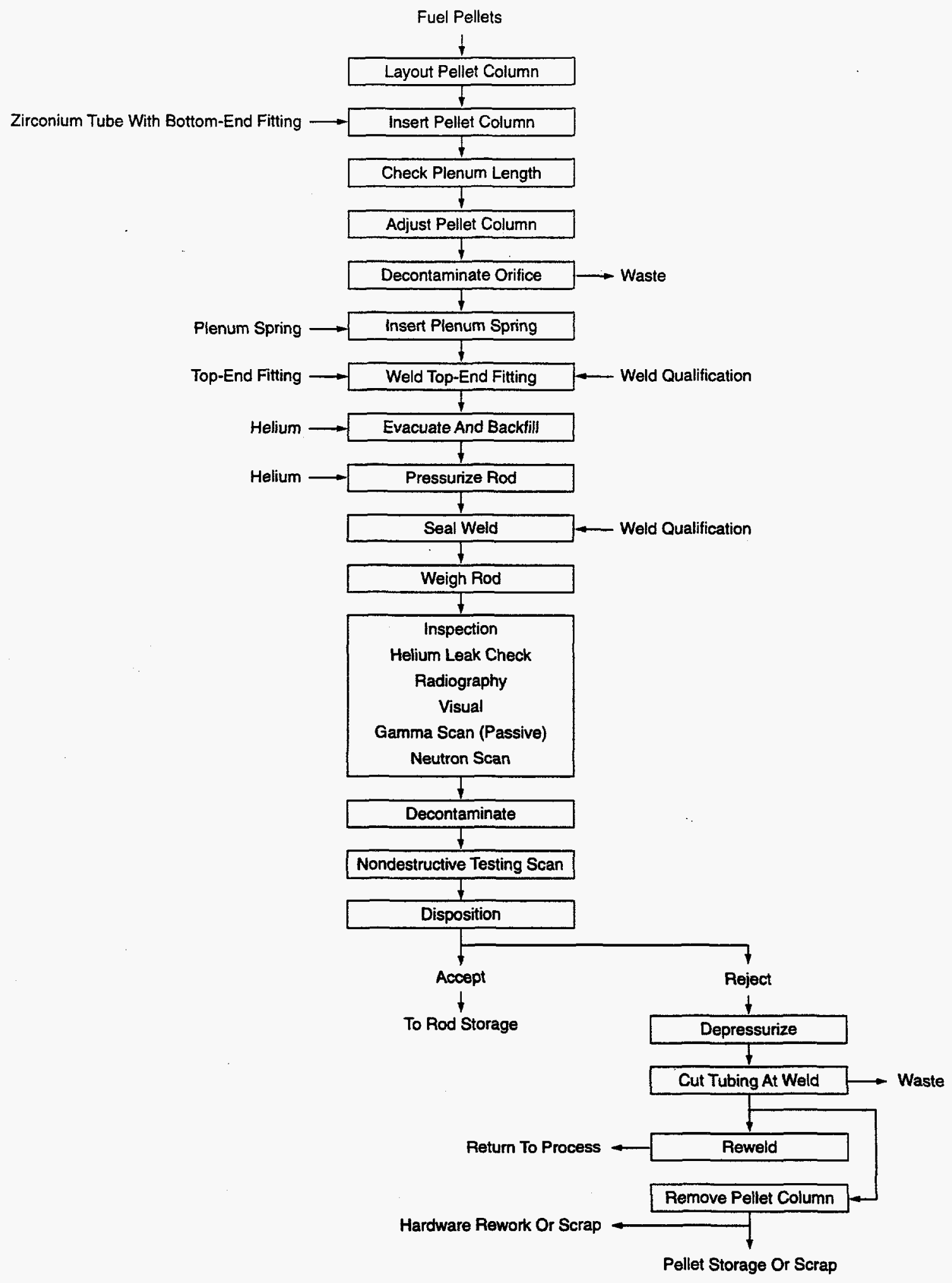

Fig. A.4. Detailed flow sheet of LA rod fabrication. 


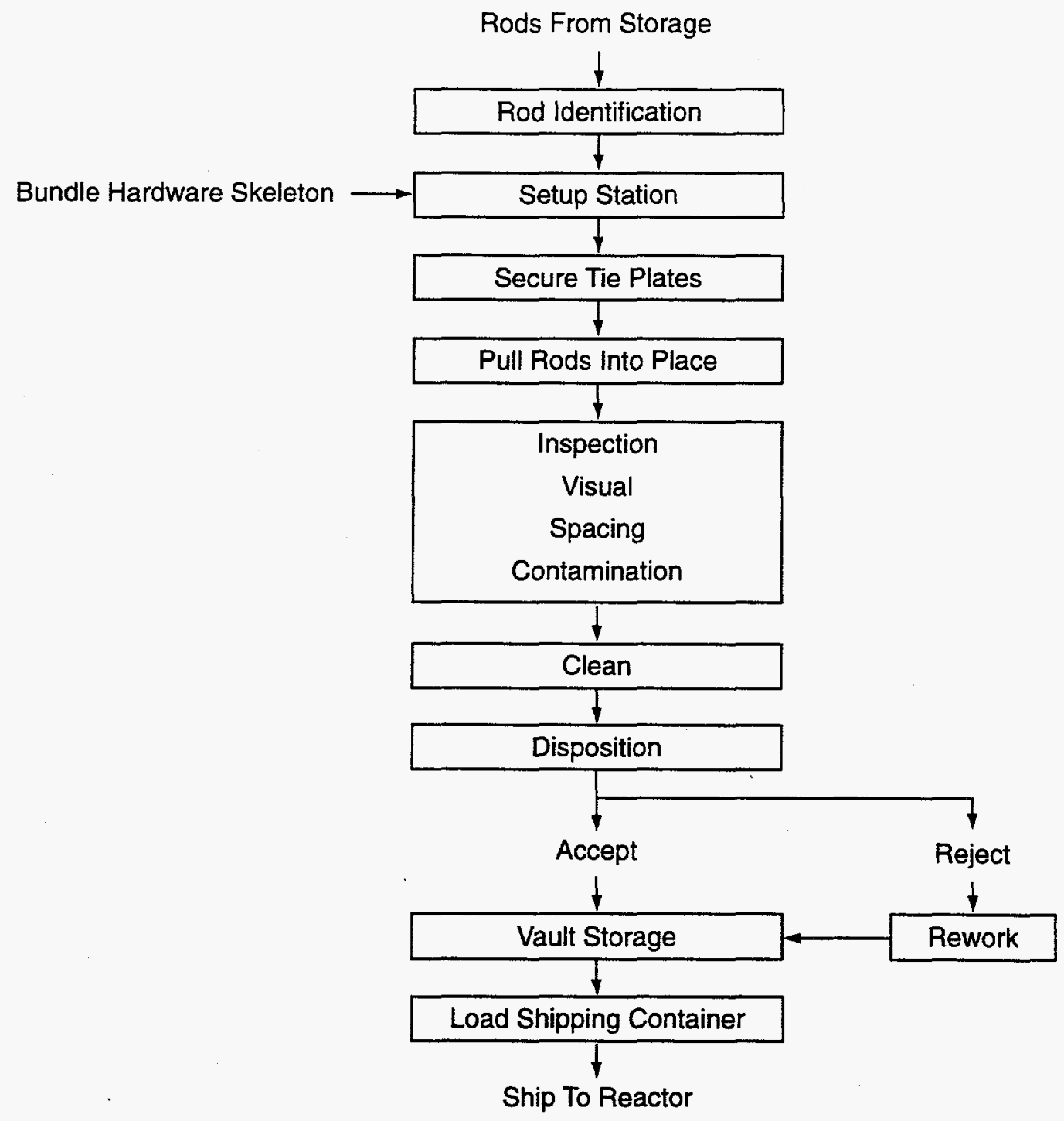

Fig. A.5. Detailed flow sheet of LA bundle assembly (LWR). 
Page Intentionally Blank

A- 8 
APPENDIX B-LA EIS DATA REPORT ASSUMPTIONS

B-1 
Page Intentionally Blank

B-2 
Table B.1. Assumptions used for the LA EIS data reports

1. Material and process requirements are based on producing PWR fuel.

2. $\mathrm{PuO}_{2}$ powder will meet the ASTM C 757-90 specification as received.

3. Depleted $\mathrm{UO}_{2}$ powder will meet the ASTM specification as received.

4. Depleted $\mathrm{UO}_{2}\left(\right.$ no $\left.\mathrm{PuO}_{2}\right)$ will be used to perform all system shakedown tests before introducing plutonium.

5. Table 3 is in terms of $\mathrm{HM}$. The factor for converting $\mathrm{PuO}_{2}$ and depleted $\mathrm{UO}_{2}$ to $\mathrm{HM}$ is $88 \%$.

6. All waste plutonium will be canned and sent to the Immobilization Program for final disposition.

7. All plutonium scrap will be recycled using a dry process.

8. All liquid wastes generated are ancillary to the base process (i.e., laundry, mop water, etc.)

9. Sintering furnaces will stay at temperature during the entire 3-year mission and 1-year startup.

10. Sintering furnaces will be purged with a mixture of argon and $6 \%$ hydrogen at a rate of $10 \mathrm{~L} / \mathrm{min}$.

11. Powder glove boxes will be purged with nitrogen to reduce the potential for oxidizing $\mathrm{UO}_{2}$.

12. All calculated numbers have a precision of no more than two significant figures.

13. The facility will be built on an existing DOE site with a minimum of $4500 \mathrm{ft}^{2}$ available space $\left(3000 \mathrm{ft}^{2}\right.$ for MOX rod processing, $1000 \mathrm{ft}^{2}$ for bundling activities, and $500 \mathrm{ft}^{2}$ for fuel bundle storage).

14. The site will have an existing infrastructure in place to accept the LA mission.

15. Personnel will be required to support a process capacity of $\sim 2$ MT HM per year.

16. Personnel involved in SNM operations must work in pairs and follow specific safety precautions detailed by the site.

17. Personnel must attend required site training. A staffing requirement for training purposes has been included in this estimate.

18. Space will be allocated for safe secure transports (SSTs) carrying plutonium and transportation for uranium so that loading can be accomplished on a follow-up operating shift if the transport arrives near or following the close of standard business.

19. As with the MOX fuel fabrication facility estimate, the staffing requirements assume that $\sim 20 \%$ of the employee's time will be taken through training, vacation, personal leave, or illness. Even though employees cannot necessarily transition from one position to another, a contingency was added to account for nonproductive time.

20. Homogenization of the $\mathrm{PuO}_{2}$ powder will be done at the LA fuel fabrication facility, as will gallium removal operations 

ANL-W RESPONSE TO THE SUPPLEMENTAL LEAD TEST ASSEMBLY EIS DATA CALL 
Page Intentionally Blank 


\title{
ANL-W Response to the Supplemental Lead Test Assembly EIS Data Call
}

\author{
1. GENERAL SITE DATA NEEDS
}

\subsection{CURRENT MISSION}

The Argonne National Laboratory-West (ANL-W) site at the Idaho National Engineering and Environmental Laboratory (INEEL) began a Redirected Nuclear Research and Development Program in FY 1995. The Redirected Program involves research to help solve near-term high-priority missions including the treatment of U.S. Department of Energy (DOE) spent nuclear fuel and reactor decontamination and decommissioning (D\&D) technologies. ANL-W is also currently in the process of conducting shutdown and termination activities for the Experimental Breeder Reactor-II (EBR-II). A number of research and support facilities exist within the ANL-W site that contribute to the total volume of waste generated at ANL-W. These facilities currently generate radioactive low-level waste (LLW), radioactive transuranic (TRU) waste, hazardous waste, mixed waste, sanitary waste, and industrial waste.

\subsection{SITE HISTORY}

ANL-W was established in the mid-1950s and is located $~ 30$ miles west of Idaho Falls. ANL-W houses extensive support facilities for three major reactors: the Transient Reactor Test Facility (TREAT), the EBR-II, and the Zero Power Physics Reactor (ZPPR).

The first reactor to operate at the ANL-W site was TREAT, which was built in 1959. As its name implies, TREAT was designed for overpower transient tests of fuel. Its driver fuel, consisting of finely divided uranium oxide $\left(\mathrm{UO}_{2}\right)$ in a graphite matrix, has a high heat capacity that enables it to withstand tests in which experimental fuel may be melted. Used extensively at first for safety tests of water-reactor fuels, TREAT is now used mainly for safety tests for various fuel types as well as for nonreactor experiments. It has periodically undergone modification as part of the TREAT upgrade project.

The EBR-II, a $62.5-\mathrm{MW}(\mathrm{t})$ reactor which went into operation in 1964 , is capable of producing 19.5-MW of electrical power in the liquid-metal reactor power plant. It is a pool-type sodium-cooled reactor, designed to operate with metallic fuel. It was provided with its own Fuel Cycle Facility (FCF) adjacent to the reactor building for remote pyrometallurgical reprocessing and refabrication of reactor fuel. The FCF has operated since 1964, providing five complete core loadings of recycled fuel for EBR-II.

Over the years, the mission of EBR-II has been redirected from that of a demonstration power-plant with integral fuel cycle to that of an irradiation test facility for mixed uranium-plutonium oxide fuels for future liquid-metal reactors. The pyrometallurgical process used in the FCF was not suitable for ceramic fuels so the FCF was converted to the Hot Fuel Examination Facility South (HFEF/S).

EBR-II continued to be fueled with metallic uranium driver fuel for operating convenience. This fuel was gradually improved to greatly increase its burnup, thus contributing to a high plant factor for irradiation tests. Over the years of operation, much valuable operating experience has been gained on sodium systems, including the removal and maintenance of primary sodium pumps and other components. In the 1970s, the mission of the EBR-II was again shifted in emphasis, this time to the Operational Reliability Testing Program. This program studied the milder but more probable types of fuel and reactor malfunctions that could lead to accident sequence. In addition to preventing accidents, its aim was to better define the operating limits and tolerable faults in reactor operation, thus leading to both safer and more economical plants. The components of this program in EBR-II included tests of fuel to and beyond cladding breach, loss-of-flow tests, mild power transients, and studies of worker-machine interfaces.

In the early 1980s, ANL-W reexamined the basic design of liquid-metal-cooled fast reactors. The results of this study led to the Integral Fast Reactor (IFR) concept. The IFR incorporates four basic elements: sodium cooling; a pool configuration; a compact, integral fuel cycle facility; and a ternary metal alloy fuel. Modifications to the EBR-II and the HFEF/S facilities have been made to support the pyroprocessing and fuel manufacturing for the IFR demonstration project. ANL-W is currently in the process of 
conducting shutdown and termination activities for the EBR-II. These shutdown activities include defueling and draining the primary and secondary sodium loops and placing the reactor in a radiologically safe condition.

ZPPR was put into operation at ANL-W in 1969. ZPPR is large enough to enable core-physics studies of full-scale breeder reactors that will produce up to $1000 \mathrm{MW}$. ZPPR has also been used for mockups of metallic cores and space-reactor cores. ZPPR was placed in programmatic standby in FY 1989.

The latest available annual site environmental monitoring report is provided in Attachment 1, Argonne National Laboratory-West 1996 Environmental Surveillance Report.

The current 1997 employment level for the ANL-W site is 728 full-time equivalents (FTEs).

Site worker radiological exposure data for the last 3 years are provided in Table 1.

Table 1. Exposure data for ANL $-W$ site

\begin{tabular}{cccccc}
\hline & \multicolumn{2}{c}{ Radiation worker dose } & & \multicolumn{2}{c}{ All workers } \\
\cline { 2 - 3 } \cline { 5 - 5 } Year & (mrem) & (person-rem) & & (mrem) & (person-rem) \\
\hline 1994 & 34 & 28 & & 19 & 34 \\
1995 & 50 & 41 & & 27 & 43 \\
1996 & 56 & 45 & & 31 & 45 \\
\hline
\end{tabular}

\subsection{THE AFFECTED ENVIRONMENT}

\subsubsection{Site Description}

The ANL-W site is accessible by a single paved road $\sim 3$-miles $(5-\mathrm{km})$ long. This road is open only for official business travel. The intersection of the road and U.S. Highway 20 marks the approximate site boundary. INEEL occupies 890 miles $^{2}\left(2300 \mathrm{~km}^{2}\right)$ of land in southeastern Idaho on the edge of the Eastern Snake River Plain. INEEL's eastern boundary is $\sim 29$ miles $(47 \mathrm{~km}$ ) west of Idaho Falls, Idaho. ANL-W is located in the southeastern portion of INEEL. Approximately $95 \%$ of the INEEL land area has been reserved for use by DOE. The remaining 5\% of the area includes public highways (U.S. Highways 20 and 26 and Idaho Highways 22, 28, and 33) and the EBR-I National Historic Landmark. Public access is limited to highways and the EBR-I facility. Most of INEEL is unfenced, but security fences and guard posts are located around facilities (including ANL-W) to preclude public access.

At the ANL-W site, DOE has administrative control over a roughly rectangular area, encompassing $\sim 810$ acres ( $328 \mathrm{ha}$ ). The site facilities cover only a small portion [ -50 acres $(20 \mathrm{ha})]$ of this administrative area, which accounts for $6 \%$ of the site. Site facilities are within a topographically closed drainage basin.

The region of influence for INEEL is a seven-county area comprising Bingham, Butte, Bonneville, Clark, Jefferson, Bannock, and Madison counties. This region had a 1990 population of 219,713 . Historically, the regional economy has relied predominantly on farming and ranching; mining is also an important economic component.

The populated area nearest to ANL-W is Atomic City, Idaho (population 25), located about 18 miles $(29 \mathrm{~km})$ to the southwest. Idaho Falls, Idaho, with a population of $\sim 45,000$, lies 39 miles $(63 \mathrm{~km})$ to the east and is the closest major population area. At a distance of 36 miles $(58 \mathrm{~km})$ to the south-southeast, the 1000 residents of the town of Fort Hall, Idaho, constitute the nearest minority population center.

With a predominately Native American population, the Fort Hall Indian Reservation (1990 U.S. census population of 2681, which includes the town of Fort Hall) is administered by the Shoshone-Bannock Nation. It is also the current home of the Lemhi Nation.

The population within a $50-\mathrm{mile}(80-\mathrm{km})$ circle centered at ANL-W has been characterized for the purpose of identifying whether any disproportionately high and adverse impacts exist to minority and lowincome communities. The population surrounding INEEL is $7 \%$ minority and $14 \%$ low-income, based on U.S. Bureau of Census information. 
INEEL has a semi-arid climate typical of high valleys in the mountains west of the Continental Divide. The average annual precipitation is $9 \mathrm{in} .(230 \mathrm{~mm})$. Snowfall averages $26.0 \mathrm{in}$. $(660 \mathrm{~mm})$ per year. The winters are characteristically cold with snow cover often lasting from December through March. Summers are very warm with temperatures that occasionally reach $100^{\circ} \mathrm{F}\left(38^{\circ} \mathrm{C}\right)$ or more. The average annual temperature is $\sim 41.7^{\circ} \mathrm{F}\left(5.4^{\circ} \mathrm{C}\right)$.

\subsubsection{Air Quality and Meteorology}

INEEL is not located in a nonattainment area (an area that cannot meet standards for designated pollutants) with respect to any of the National Ambient Air Quality Standards. INEEL, like most of the United States, is located in a Class II area, an area where moderate, well-controlled growth is permitted. Portions of nearby Bannock and Power counties [within 50 miles $(80 \mathrm{~km})$ of INEEL] are nonattainment areas. Three "prevention of significant deterioration Class I ambient (surrounding) air quality" areas have been designated in the vicinity of ANL-W. Class I areas are national parks and national wilderness areas larger than 6,000 acres. These are Craters of the Moon Wilderness Area, 33 miles (53 km) west-southwest from the center of ANL-W; Yellowstone National Park, 83 miles $(133 \mathrm{~km})$ east-northeast from the center of ANL-W; and Grand Teton National Park, $\sim 95$ miles ( $153 \mathrm{~km}$ ) east from the center of ANL-W.

Although INEEL is in a belt of prevailing westerlies, these winds are normally channeled by the adjacent mountain ranges into a southwest wind. The annual average wind speed measured at the 20 - $\mathrm{ft}$ $(6.1-\mathrm{m})$ level at the INEEL Central Facilities Area weather station is $7.5 \mathrm{miles} / \mathrm{h}(12.1 \mathrm{~km} / \mathrm{h})$. Monthly average values range from 5.1 miles $/ \mathrm{h}(8.2 \mathrm{~km} / \mathrm{h})$ in December to $9.3 \mathrm{miles} / \mathrm{h}(15 \mathrm{~km} / \mathrm{h})$ in April and May. The highest hourly average near-ground wind speed measured at INEEL is $51 \mathrm{miles} / \mathrm{h}(82 \mathrm{~km} / \mathrm{h})$.

Other than thunderstorms, severe weather is uncommon. Ten funnel clouds (tornadoes not touching the ground) and two low-intensity tornadoes (low-velocity whirlwinds) were reported on the INEEL property between 1950 and 1988 .

\subsubsection{Soils/Geology}

The ANL-W site is situated on the Eastern Snake River Plain at an elevation of $5125 \mathrm{ft}(1562 \mathrm{~m})$ above sea level. The Eastern Snake River Plain is on an area of low seismicity that is adjacent to the seismically active Intermountain Seismic Belt and Centennial Tectonic Belt, and lies in Uniform Building Code Seismic Risk Zones 2B and 3. An earthquake with a magnitude of 7.3 occurred near Borah Peak, Idaho, on October 28, 1983. The epicenter (part of the earth's surface directly above the earthquake) was about 40 miles $(64 \mathrm{~km})$ from INEEL. Although the shock was felt at INEEL, no structural or safety-related damage occurred to INEEL structures. On August 17, 1959, a magnitude 7.1 earthquake occurred near Hebgen Lake, Montana; the epicenter was about 100 miles $(160 \mathrm{~km})$ northeast of INEEL and was felt at INEEL but caused no damage. These earthquakes are included in a total of 29 earthquakes greater than a magnitude of 5.5 that have occurred within 200 miles $(322 \mathrm{~km})$ of INEEL since 1884 . More detailed information and graphic representations of the geology and historical earthquakes can be found in A Programmatic Spent Nuclear Fuel Management and Idaho National Engineering Laboratory Environmental Restoration and Waste Management Programs: Final Environmental Impact Statement, Volume 2, Part A, Sect. 4.6, "Geology."

\subsection{OFF-SITE MONITORING}

An annual site surveillance program is conducted at ANL-W, and an Environmental Surveillance Report is published annually. Surveillance activities conducted at ANL-W include measurement of radionuclides in airborne particulate and potable water. In addition, the Radiological and Environmental Sciences Laboratory of INEEL places 12 thermoluminescent dosimeters at various locations around the ANL-W perimeter to measure levels of penetrating radiation. As described in the 1995 Environmental Surveillance Report, airborne particulate gross beta and actinide concentrations were detected at ANL-W; however, the concentrations were not different than those measured in communities surrounding INEEL. Potable water from the distribution system is analyzed quarterly for alpha, beta-gamma, and tritium 
activity. No radioactivity due to operations at ANL-W has been found. Similarly, thermoluminescent dosimeters posted along the site security perimeter routinely register exposures only slightly higher than background levels measured in distant communities The annual dosimeter doses measured ranged from $0.008 \mathrm{rem}$ less than the distant background measurement of $0.063 \mathrm{rem}$, to $0.048 \mathrm{rem}$ higher than the background level. The higher doses correlate with nearby storage of radioactive materials. These analytical results indicate that site boundary or off-site impacts associated with current ANL-W operations are minimal.

\subsection{CULTURAL RESOURCES}

Prehistoric and historic archaeological resources have been identified in the INEEL area, mostly at surveyed sites near major facilities. The EBR-I (which is not located at the ANL-W site) is listed on the National Register of Historic Places. EBR-II has been designated as an American Nuclear Society Historical Landmark. INEEL is not listed on the National Register of Historic Places nor has it been proposed for listing. DOE has consulted with the State of Idaho Historic Preservation Officer concerning any effect the proposed action might have on the historic significance of the EBR-II and associated facilities.

The Shoshone-Bannock Tribes consider the land occupied by the INEEL to be culturally important. In 1992, a Memorandum of Agreement was signed between the Tribes and the DOE-Idaho Operations Office granting access to the Middle Butte area and other areas within the boundaries of the INEEL for the performance of sacred or religious ceremonies or other cultural or educational activities in accordance with safety, health, and national security considerations. The ANL-W site has not been affected.

\subsection{REGULATORY FRAMEWORK}

The DOE/ANL-W acts as owner and/or co-operator with the Idaho Department of Health and Welfare, Division of Environmental Quality, on environmental issues concerning air and hazardous materials compliance. The Idaho Department of Health and Welfare, Division of Environmental Quality, has been delegated primacy by the U.S. Environmental Protection Agency (EPA) to enforce hazardous material compliance and air compliance on the INEEL. The State enforces hazardous material compliance under the Hazardous Waste Management Act of 1983 (HWMA), which incorporates by reference the Resource Conservation and Recovery Act (RCRA) in Idaho. Air compliance is handled under the INEEL Operating Permit which is required by the Clean Air Act (CAA). The CAA is incorporated by reference in the Idaho Administrative Procedures Act (IDAPA) 16.01.01, Title 1. All facilities on the INEEL, including EBR-II, are considered by the State of Idaho to be one air emissions source and all hazardous waste units are considered to be one hazardous waste facility.

\subsection{COMPLIANCE AGREEMENTS}

The ANL-W site is currently part of two compliance agreements and associated consent orders entered into with the State of Idaho covering treatment and/or shipment of waste/fuel from INEEL. The Site Treatment Plan (issued November 30, 1995) Federal Facilities Compliance Act Consent Order (OCC-95-201), signed October 31, 1995, provides a schedule for treatment and disposal of radioactive mixed waste on INEEL. This plan was revised to reflect the compliance schedules in the Settlement Agreement and Consent Order discussed in the following paragraph. The Radioactive Scrap and Waste Facility (RSWF) at ANL-W contains a significant quantity of this material which must be handled remotely. The first compliance milestone, due September 1997, is to propose a project management plan to the State of Idaho that defines how the radioactive mixed waste in the RSWF will be treated for disposal.

The second compliance document is the Settlement Agreement and Consent Order issued by the Court on October 17, 1995, in the actions Public Service Co. Of Colorado v. Batt, No. CV 91-0035-S-EJL (D. Id.) And United States v. Batt, No. CV 91-0054-S-EJL (D. Id.). This document lists dates for the treatment and/or shipment of TRU (compliance completion date of December 31, 2018), high-level, and spent fuel (compliance completion date of January 1,2035 ) from the State of Idaho. 
Failure to comply with the terms of the consent orders may result in an enforcement action for any relief available under the HWMA, which enacts RCRA in the state of Idaho.

\subsection{ENVIRONMENTAL JUSTICE}

An Executive Order requires each federal agency to identify and address disproportionately high and adverse human health or environmental effects of its programs, policies, and activities on minority and low-income communities.

In A Programmatic Spent Nuclear Fuel Management and Idaho National Engineering Laboratory Environmental Restoration and Waste Management Programs: Final Environmental Impact Statement, minority and low-income population distribution maps were prepared and analyzed using the ANL-W site as the center point. The maps were prepared using 1990 census data available from the U.S. Bureau of the Census. Tiger Line files that contain political boundaries and geographical features and Summary Tape Files 3A (as processed by EPA) that contain demographic information (USBC1992) data were resolved to the census tract group level.

Approximately 172,000 people reside within the 50-mile $(80-\mathrm{km})$ radius of the ANL-W site. This distance was chosen to allow for comparison with population doses resulting from similar projects that were analyzed in A Programmatic Spent Nuclear Fuel Management and Idaho National Engineering Laboratory Environmental Restoration and Waste Management Programs: Final Environmental Impact Statement. Of that total population, only $7 \%(11,700$ people) are classified as minority individuals. These individuals reside primarily to the southeast of the ANL-W site. The minority population composition is primarily Hispanic, Native American, and Asian. Most of the Fort Hall Indian Reservation of the Shoshone-Bannock Tribes lies largely within 50 miles $(80 \mathrm{~km})$ of the ANL-W site. Of the total nearby population of $\sim 172,000$ people, $14 \%$, or $-23,000$ people, fall within the definition of "low-income." Census tracts show that low-income populations also largely reside southeast of the ANL-W site. 


\section{LOCATION-SPECIFIC DATA NEEDS}

\subsection{GENERAL FACILITIES INFORMATION NEEDS}

The following are existing environmental assessments (EAs)/environmental impact statements (EISs) for specific facilities/buildings that would be modified for LA fabrication activities:

- DOE, A Hot Fuel Examination Facility/South: Final Environmental Assessment, DOE/EA-0377, May 1990.

- DOE, A Programmatic Spent Nuclear Fuel Management and Idaho National Engineering Laboratory Environmental Restoration and Waste Management Programs: Final Environmental Impact Statement, DOE/EIS-0203-F, April 1995.

- DOE, Electrometallurgical Treatment Research and Demonstration Project in the Fuel Conditioning Facility At Argonne National Laboratory-West, Final Environmental Assessment, DOE/EA-1148, May 1996.

The current employment levels for the Fuel Manufacturing Facility (FMF) and ZPPR are 18 FTEs, not including security personnel. (The number of security personnel is classified information.)

Radiation exposure data for the facility/building radiation workers and other workers are given in Table 1 in Sect. 1.

\subsection{SPECIFIC FACILITIES INFORMATION NEEDS}

\subsubsection{Land Use}

Table 2 provides the requested land use information.

Table 2. Land use information

\begin{tabular}{ll}
\hline Requested information & \multicolumn{1}{c}{$\begin{array}{c}\text { ANL-W } \\
\text { (facility) }\end{array}$} \\
\hline & FMF/ZPPR Complex \\
Latitude & $43 E 36^{\prime} \mathrm{N}$ \\
Longitude & $112 \mathrm{E} \mathrm{39} \mathrm{W}$ \\
Elevation above NGVD & $5126 \mathrm{ft}$ \\
\hline a NGVD
\end{tabular}

\subsubsection{Air Quality}

Air pollutant releases such as radionuclides and hazardous air pollutants/toxic air pollutants do not occur from the FMF and ZPPR facilities. The ANL-W site does release these pollutants from the operation of on-site boilers that produce steam for site heating. The ANL-W site is considered part of INEEL for this air pollutant reporting. Table 3 lists the pollutants and their concentrations on INEEL; ANL-W is included. The maximum annual value is the permitted limit for the pollutant.

Section 1.3.2 provides additional background information on this topic.

The U.S. Weather Bureau established a monitoring station at the Central Facilities Area (CFA) in 1949. Historical climatological observations from this area have been compiled by Clawson (1989). A 250$\mathrm{ft}$ tower is also located just outside the east security fence of the ANL-W area; however, this tower has not been in continuous operation for as long as the CFA station. The longest and most complete record of INEEL meteorological observations exists for the CFA weather station (see attached map).

The most recent annual wind rose data from the nearest data station are attached.

Information on the meteorological conditions at the site is provided in Sect. 1.3.2. 
Table 3. Ambient air quality information1996 air emissions for INEEL

\begin{tabular}{lcc}
\hline \multicolumn{1}{c}{ Pollutant } & $\begin{array}{c}\text { Actual hourly } \\
(\mathrm{lb} / \mathrm{h})\end{array}$ & $\begin{array}{c}\text { Maximum annual } \\
\text { (ton/year) }\end{array}$ \\
\hline Carbon monoxide & $1.6 \times 10^{2}$ & $9.7 \times 10^{2}$ \\
Nitrogen oxides & $4.8 \times 10^{2}$ & $3.2 \times 10^{3}$ \\
PM-10 & $6.6 \times 10^{1}$ & $3.4 \times 10^{2}$ \\
Sulfur oxides & $1.5 \times 10^{2}$ & $1.8 \times 10^{3}$ \\
$\quad$ Volatile organic & $.9 .5 \times 10^{1}$ & $5.9 \times 10^{1}$ \\
$\quad$ compound-nonmethane & & \\
\hline
\end{tabular}

\subsubsection{Water}

Local creeks and streams originate in the mountains and much of their water is diverted for irrigation before reaching INEEL. There is little flow of water on-site, and no surface water runs off INEEL. All rivers and streams entering the INEEL flow intermittently and include the Big Lost River, Little Lost River, and Birch Creek. ANL-W is located $\sim 11$ miles $(18 \mathrm{~km})$ from the Big Lost River, which is the nearest of these streams. The only surface waters at ANL-W are from stormwater runoff, discharge from the Main Cooling Tower system to wastewater ditches and the Industrial Waste Pond, and discharges from the site sanitary systems to the membrane-lined sanitary lagoons (see attached map).

ANL-W is not located on a floodplain.

The Snake River Plain Aquifer underlies INEEL and ANL-W and has been designated as a solesource aquifer. Depths to the water table at the INEEL range from $200 \mathrm{ft}(61 \mathrm{~m})$ in the north to $900 \mathrm{ft}$ $(274 \mathrm{~m})$ in the south. At ANL-W, the depth to the aquifer is $\sim 600-700 \mathrm{ft}(180-210 \mathrm{~m})$. Aquifer recharge sources include irrigation diversions, valley underflow, river seepage, precipitation, and to a much lesser extent, INEEL percolation ponds. Flows in the largely unconfined Snake River Plain Aquifer are generally to the southwest. Groundwater flows at speeds ranging from 5 to $20 \mathrm{ft} / \mathrm{d}(1.5$ to $6.1 \mathrm{~m} / \mathrm{d})$. Small concentrations of tritium and strontium-90 from the Idaho Chemical Processing Plant and Test Reactor Area have been found in the aquifer and have exceeded maximum contaminant levels on-site. Extremely low concentrations of iodine-129 and tritium have migrated off the INEEL site, but the concentrations of both the iodine-129 and tritium at the site boundary were orders of magnitude below maximum contaminant levels for drinking water. Water samples from monitoring and production wells at and around the ANL-W site indicate that no contaminants are in the aquifer resulting from ANL-W operations or activities.

The Snake River Plain Aquifer is the only sole-source aquifer beneath the proposed location. Groundwater beneath the proposed location is classified as a Special Use Aquifer by EPA and Class 1 Drinking Water by the State of Idaho. The ultimate source of water for the ANL-W site is from the Snake River Plain Aquifer. The water is drawn from the aquifer by two deep production wells located on the ANL-W site.

Activities at the ANL-W site do not result in surface or groundwater discharges to navigable waterways or recreational fisheries. Therefore, the proposed action would not impact recreational fisheries and would be in compliance with Executive Order 12962 of June 7, 1995, "Recreational Fisheries."

The discharge point for the ANL-W site is the Industrial Waste Pond. A land application permit for this discharge has been submitted to the State of Idaho for approval.

\subsubsection{Biological}

\subsubsection{Plant and animal species}

Wildlife species present in and around ANL-W include birds, mammals, and reptiles that are associated with facilities, sagebrush-steppe, rock outcroppings, deciduous trees and shrubs, grasslands, and water (e.g., Industrial Waste Pond, Sewage Lagoons, and drainage ditches). Both terrestrial and aquatic species are potentially present. Sagebrush communities surrounding ANL-W typically support a number of species 
including sage grouse (Centrocercus urophasianus), sage sparrow (Amphispiza belli), and pronghorn (Antilocapra americana). Rock outcroppings associated with these communities also provide habitat for species such as bats, woodrats (Neotoma cinerea), and sensitive species such as the pygmy rabbit (Brachylagus idahoensis). Nearby grasslands serve as habitat for species including the western meadowlark (Sturnella neglecta) and mule deer (Odocoileus hemionus). ANL-W facility structures also provide important wildlife habitat. Buildings, lawns, ornamental vegetation, and ponds are utilized by a number of species such as waterfowl, raptors, rabbits, and bats. Lawns can be an important resource to species at Waste Area Group (WAG) 9 (the source of the water for these lawns is from the ANL-W deep wells). Currently, no surface hydrology exists to support fish. Current and future aquatic invertebrates are, however, supported by habitat provided by the sewage lagoons while they are receiving wastewaters from the facility.

\subsubsection{Threatened and endangered species}

Endangered animal species (peregrine falcon) and the threatened animal species (bald eagle) have been occasionally sighted on lands within the boundaries of the INEEL. Neither species is known to nest on-site, and neither is commonly observed near facilities. No Federal- or State-listed plant species that are endangered occur at the INEEL. A Programmatic Spent Nuclear Fuel Management and Idaho National Engineering Laboratory Environmental Restoration and Waste Management Programs: Final Environmental Impact Statement, Volume 1, Appendix B, contains the latest Fish and Wildlife Service listing (dated January 26, 1994) of endangered and threatened species on or around the INEEL.

No known wetlands or other sensitive habitat are within a $1.6-\mathrm{km}$ radius of the proposed facility location.

\subsubsection{Infrastructure}

Table 4 provides facility infrastructure information for the proposed facility location.

Table 4. Facility infrastructure information

\begin{tabular}{lrrrrrr}
\hline \multirow{2}{*}{$\begin{array}{l}\text { Utility usage and capacity } \\
\text { information for utilities }\end{array}$} & \multicolumn{2}{c}{ Current usage } & & \multicolumn{2}{c}{ Current capacity } \\
\cline { 2 - 3 } \cline { 5 - 6 } \cline { 5 - 6 } & Average & \multicolumn{1}{c}{ Peak } & & Average & \multicolumn{1}{c}{ Peak } \\
\hline Water (gal/year) & $1,500,000$ & $2,000,000$ & & $4,000,000$ & $4,000,000$ \\
Sanitary wastewater (gal/year) & 103,400 & 103,400 & & $1,600,000$ & $1,600,000$ \\
Process wastewater (gal/year) & $1,611,000$ & $1,611,000$ & & $15,000,000$ & $15,000,000$ \\
Electricity (MWh/year) & 4,200 & 5,088 & & 7,000 & 7,000 \\
Natural gas & 0 & 0 & & 0 & 0 \\
Fuel oil & 0 & 0 & & 0 & 0 \\
Steam, $\mathrm{kg} / \mathrm{h}(\mathrm{lb} / \mathrm{h})$ & 690 & 2,200 & & 4,400 & 4,400 \\
\hline
\end{tabular}

\subsubsection{Waste Management}

Information on waste management for waste types that may result from LA fabrication activities is provided in Table 5. 
Table 5. Waste management information

\begin{tabular}{|c|c|c|c|c|c|c|}
\hline \multirow[b]{2}{*}{ Waste category } & \multirow[b]{2}{*}{$\begin{array}{l}\text { Current annual } \\
\text { generation rate }\end{array}$} & \multirow[b]{2}{*}{$\begin{array}{l}\text { Amount in } \\
\text { inventory }\end{array}$} & \multicolumn{4}{|c|}{ Available TSD facilities ${ }^{a}$} \\
\hline & & & $\begin{array}{l}\text { Building name } \\
\text { or number }\end{array}$ & TSD method & Inventory & Capacity \\
\hline \multicolumn{7}{|l|}{ Transuranic (TRU) } \\
\hline \multirow[t]{3}{*}{ Liquid, L (gal) } & 0 & 0 & RSWF-771 & Storage & $12.4 \mathrm{~m}^{3}$ & No current \\
\hline & & & RSSF-797 & Storage & & limits \\
\hline & & & HFEF-WCA-785 & $\begin{array}{l}\text { Storage/ } \\
\text { examination }\end{array}$ & & \\
\hline Solid, $\mathrm{m}^{3}\left(\mathrm{ft}^{3}\right)$ & $0.42 \mathrm{~m}^{3}$ & $12.4 \mathrm{~m}^{3}$ & INEEL RWMC & Storage & & \\
\hline \multicolumn{7}{|l|}{ Mixed TRU } \\
\hline Liquid, L (gal) & 0 & 0 & RSWF-771 & Storage & $18.7 \mathrm{~m}^{3}$ & $309 \mathrm{~m}^{3}$ \\
\hline Solid, $\mathrm{m}^{3}\left(\mathrm{ft}^{3}\right)$ & $0.5 \mathrm{~m}^{3}$ & $18.7 \mathrm{~m}^{3}$ & $\begin{array}{l}\text { RSSF-797 } \\
\text { HFEF-WCA-785 }\end{array}$ & $\begin{array}{l}\text { Storage } \\
\text { Storage/ } \\
\text { examination }\end{array}$ & & \\
\hline \multicolumn{7}{|l|}{$\begin{array}{l}\text { Low-level waste } \\
\text { (LLW) }\end{array}$} \\
\hline \multirow[t]{2}{*}{ Liquid, L (gal) } & $8150 \mathrm{gal}$ & 0 & ORSA-797 & Storage & $256 \mathrm{~m}^{3}$ & RWMC \\
\hline & & & RLWTF & $\begin{array}{l}\text { Liquid } \\
\text { evaporation }\end{array}$ & & capacity \\
\hline Solid, $\mathrm{m}^{3}\left(\mathrm{ft}^{3}\right)$ & $297 \mathrm{~m}^{3}$ & $256 \mathrm{~m}^{3}$ & INEEL RWMC & Disposal & & \\
\hline \multicolumn{7}{|l|}{ Mixed LLW } \\
\hline \multirow[t]{2}{*}{ Liquid, L (gal) } & 0 & 0 & RSWF-771 & Storage & $388 \mathrm{~m}^{3}$ & $2980 \mathrm{~m}^{3}$ \\
\hline & & & RSSF-791 & Storage & & \\
\hline \multirow[t]{2}{*}{ Solid, $\mathrm{m}^{3}\left(\mathrm{ft}^{3}\right)$} & $0.4 \mathrm{~m}^{3}$ & $388 \mathrm{~m}^{3}$ & HFEF-WCA-785 & $\begin{array}{l}\text { Storage/ } \\
\text { examination }\end{array}$ & & \\
\hline & & & SCMS-793 & $\begin{array}{l}\text { Storage/ } \\
\text { treatment }\end{array}$ & & \\
\hline \multicolumn{7}{|l|}{ Hazardous } \\
\hline Liquid, L (gal) & $\begin{array}{l}5 \mathrm{~m}^{3} \text { for both } \\
\text { liquid and } \\
\text { solid }\end{array}$ & 0 & $\begin{array}{l}\text { Facility satellite } \\
\text { accumulation } \\
\text { areas }\end{array}$ & Storage & 0 & $\begin{array}{l}\text { Commercial } \\
\text { TSDs }\end{array}$ \\
\hline Solid, $\mathrm{m}^{3}\left(\mathrm{ft}^{3}\right)$ & & 0 & $\begin{array}{l}\text { Building } 706- \\
\text { temporary } \\
\text { accumulation } \\
\text { area }\end{array}$ & & & \\
\hline \multicolumn{7}{|l|}{$\begin{array}{l}\text { Nonhazardous } \\
\text { (sanitary) }\end{array}$} \\
\hline Liquid, L (gal) & & 0 & $\begin{array}{l}\text { ANL-W- } \\
\text { industrial waste } \\
\text { pond sanitary } \\
\text { lagoons }\end{array}$ & Disposal & $\begin{array}{l}\text { Lagoons and } \\
\text { ponds }\end{array}$ & N/A \\
\hline Solid, $\mathrm{m}^{3}\left(\mathrm{ft}^{3}\right)$ & $5681 \mathrm{~m}^{3}$ & 0 & $\begin{array}{l}\text { INEEL CFA } \\
\text { landfill }\end{array}$ & & & \\
\hline \multicolumn{7}{|l|}{$\begin{array}{l}\text { Nonhazardous } \\
\text { (other) specify by } \\
\text { waste }\end{array}$} \\
\hline Liquid, L (gal) & N/A & N/A & N/A & N/A & $\mathrm{N} / \mathrm{A}$ & N/A \\
\hline Solid, $\mathrm{m}^{3}\left(\mathrm{ft}^{3}\right)$ & N/A & N/A & N/A & N/A & N/A & N/A \\
\hline
\end{tabular}

$a_{\mathrm{TSD}}=$ treatment, storage, and/or disposal.

Note: Current permits and permit limits would support the LA program for all wastes in Table 6. 
Page Intentionally Blank 


\section{ATTACHMENT 1}

ARGONNE NATIONAL LABORATORY-WEST 1996

ENVIRONMENTAL SURVEILLANCE REPORT

Environment and Restoration Department July 1997 
Page Intentionally Blank 


\section{TABLE OF CONTENTS}

1. INTRODUCTION

1.1 Physical Description of Site

1.2 ANL-W Facilities

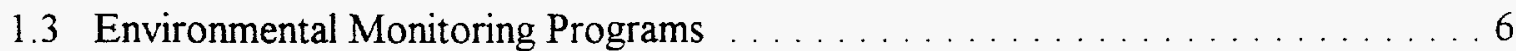

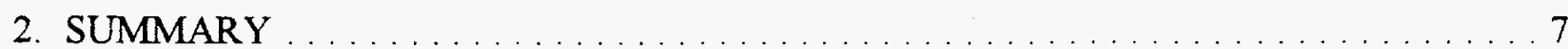

3. DATA COLLECTION, ANALYSIS AND EVALUATION $\ldots \ldots \ldots \ldots \ldots \ldots \ldots$

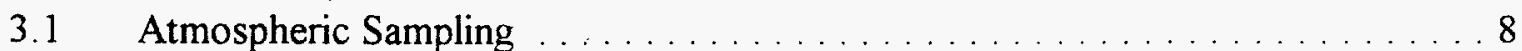

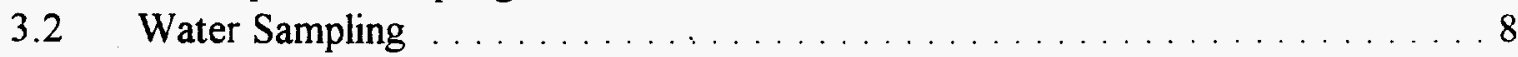

3.3 Soil Sampling . . . . . . . . . . . . . . . . . . . . . . . 9

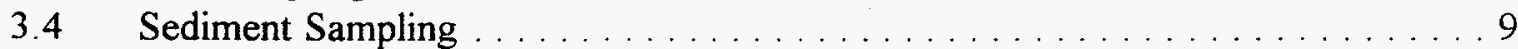

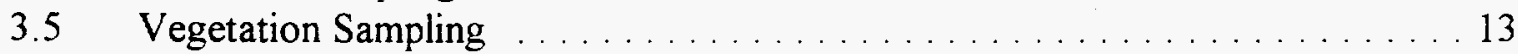

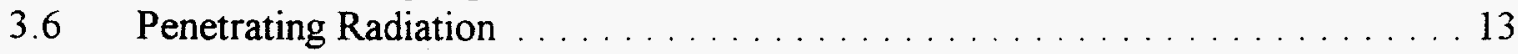

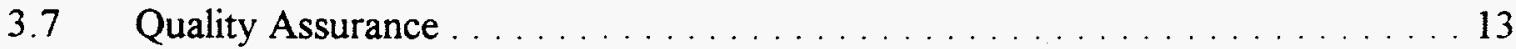

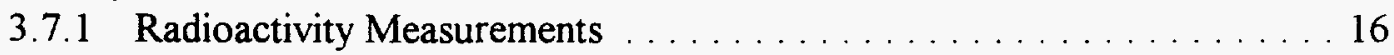

3.7 .2 Nonradioactive Measurements . . . . . . . . . . . . . . 16

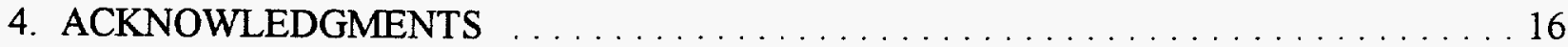

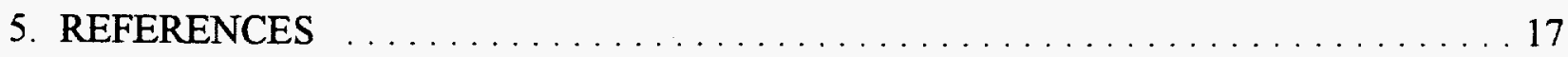

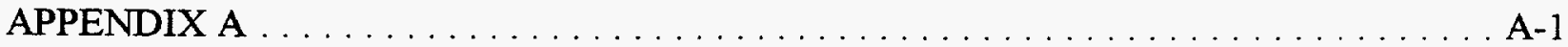

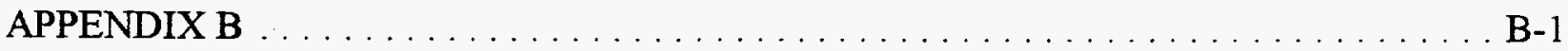

\section{LIST OF FIGURES}

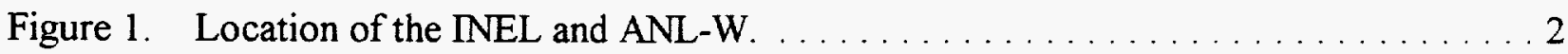

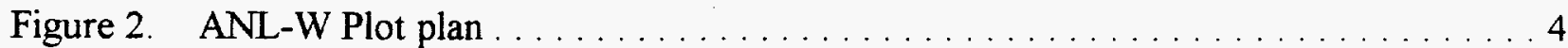

\section{LIST OF TABLES}

TABLE I $\quad$ Radiochemical Analysis of Well Water $\ldots \ldots \ldots \ldots \ldots \ldots \ldots$

TABLE II Average Radiochemical Analyses of Industrial Waste Pond and Sanitary

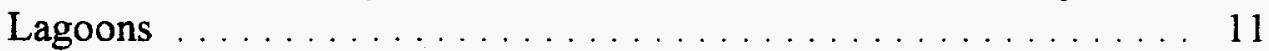

TABLE III Chemical Analysis of Industrial Waste Pond Water $\ldots \ldots \ldots \ldots \ldots \ldots \ldots$

TABLE IV Chemical Analyses of Sanitary Lagoon Water . . . . . . . . . . . . . . 14

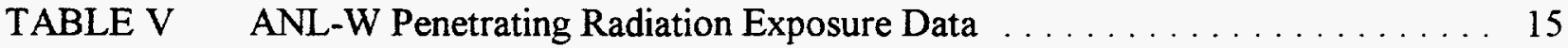

TABLE VI ANL-W TLD Quarterly Exposure $\ldots \ldots \ldots \ldots \ldots \ldots \ldots \ldots$ 


\section{INTRODUCTION}

Argonne National Laboratory has been a presence at the Idaho National Engineering Laboratory (INEL) since the INEL's inception as the National Reactor Test Site (NRTS). Argonne originally built and operated the Experimental Breeder Reactor (EBR-I) facility, the Boiling Water Reactor Experiment (BORAX) facility, and several small Zero Power Reactor (ZPR) facilities. All these older facilities are now under DOE-ID control. Construction began at the present Argonne National Laboratory-West (ANL-W) site in the late 1950s, with the plant becoming operational in stages from 1959 through the mid 1960s. The ANL-W facility was constructed for research and development of advanced nuclear power plant technology. In October 1994 the United States Congress eliminated funding for further nuclear power research. As a result, the mission of ANL-W has been shifted from advanced liquid metal reactor research to the development of decontamination and decommissioning technologies, reactor and fuel cycle safety, and treatments for spent fuel.

\subsection{Physical Description of Site}

The present ANL-W site is near the central part of the semi-arid Eastern Snake River Plain (ESRP) in southeastern Idaho. The ESRP is a structural basin about 200 miles long and 50 to 70 miles wide. It extends from the northeastern corner of Idaho, near Yellowstone Park, southwest toward the Hagerman-Twin Falls area.

The ESRP was formed largely by the eruption and emplacement of great masses of volcanic rock, as the Yellowstone Hot Spot migrated to the northeast. Weathering and erosion has only slightly modified the original emplacement forms of the volcanic materials. The surface of the plain is underlain by basalt, either at the surface or beneath a mantle of sediments (Nace et al., 1973). Landforms of the plain consist of volcanic, alluvial, and eolian features, plus lake floors and playas (sinks). Several extinct volcanic domes, craters, and cones are exposed.

The ANL-W complex is found in the southeastern portion of the INEL (Figure 1), in sections 11, 12, 13 , and 14 of T3N R32E. ANL-W has administrative control over a rectangular area, encompassing approximately 810 acres. The site facilities cover only a small portion of this administrative area (approximately 50 acres). Site facilities are within a topographically closed drainage basin. The surface of the site slopes gradually from south to north, at approximately $30 \mathrm{ft}$ per mile. Maximum topographic relief within the ANL-W administrative boundary is about $50 \mathrm{ft}$, ranging from $5110 \mathrm{ft}$ above mean sea level on the north boundary to $5160 \mathrm{ft}$ on a basalt ridge near the southeastern corner of the site. Twin Buttes are the most prominent topographic features within the INEL and are found to the southwest of ANL-W. East and Middle Twin Buttes rise 1100 feet and 800 feet respectively above the plain. Big Southern Butte is the most prominent single feature on the entire plain, rising approximately 2500 feet above the level of the plain.

Underlying the ESRP is the Snake River Plain Aquifer (SRPA), which serves as the water supply source for much of southeastern Idaho. The SRPA has been designated as a sole source aquifer by the EPA Region 10 (Federal Register, 56 FR. 50634). Estimates show nearly $2 \times 10^{9}$ acre-feet of water exist in the aquifer. Water usage at the ANL-W site was approximately 112 million gallons for 1996. Principal uses of the water are for plant operation (cooling water) and potable water. At ANL-W the aquifer is approximately $640 \mathrm{ft}$ below the surface. 
Figure 1. Location of the INEL and ANL-W

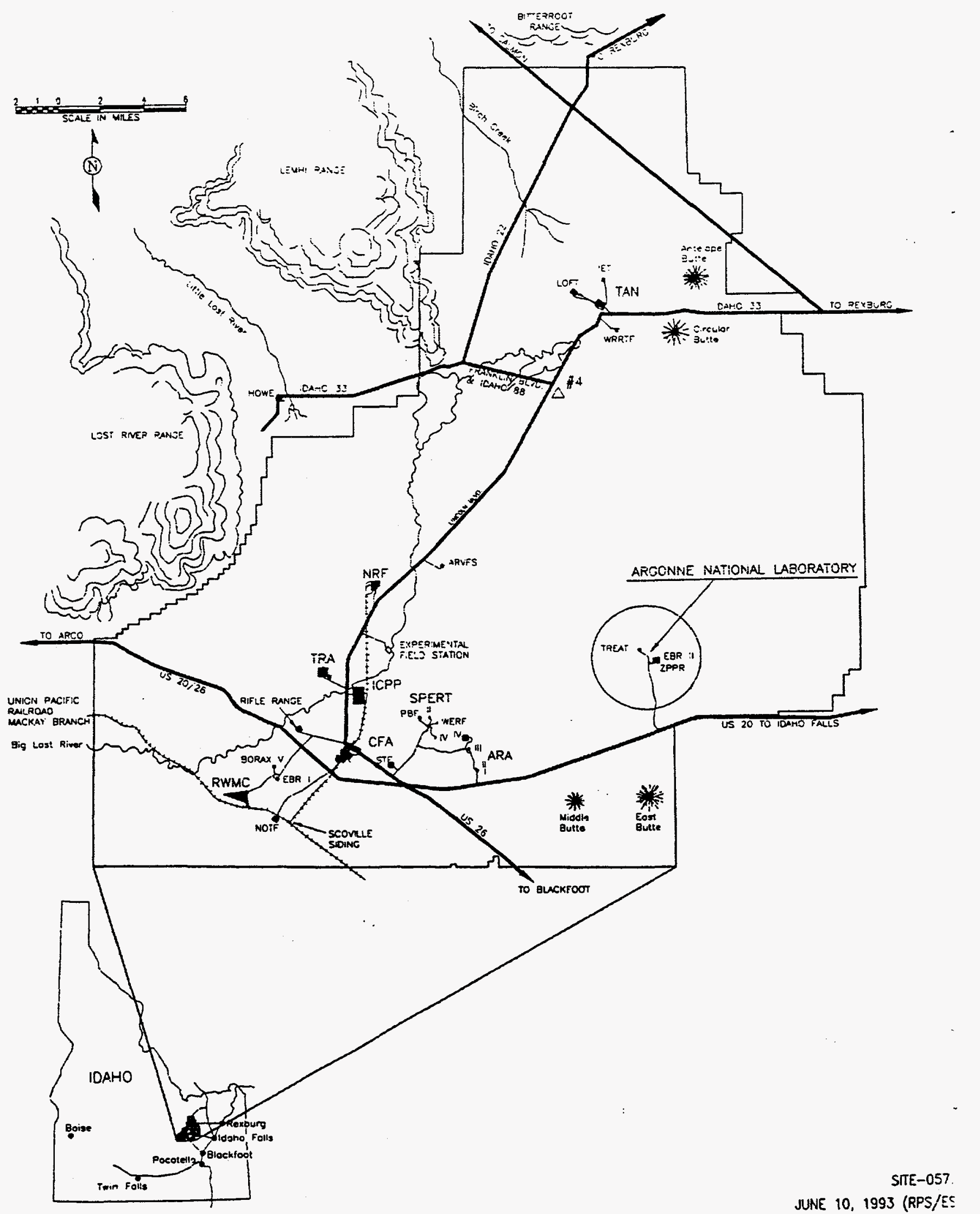


The National Oceanic and Atmospheric Administration (NOAA) and its predecessor, the U.S. Weather Bureau, have operated a meteorological observation program at the INEL since 1949. Meteorological information is compiled for the INEL as a whole. Twenty-seven meteorological observation stations are in operation on and surrounding the INEL as of December 31, 1988. A meteorological monitoring station equipped with a 250 -foot weather tower is found outside the east fence of the ANL-W facility.

Ambient air temperatures at ANL-W range from $-47^{\circ} \mathrm{F}$ to $103^{\circ} \mathrm{F}$, with an average annual temperature of $42^{\circ} \mathrm{F}$. Annual precipitation for the area is approximately 8.7 inches. Due to the channeling effect of the bordering mountain ranges, prevailing winds are from the west-southwest or southwest. Drainage winds also contribute to the overall wind flow at ANL-W. During the night hours, rapid surface cooling creates masses of cold dense air that move down-slope along the ESRP, primarily as a wind out of the north-northeast. A reverse flow occurs during the day as the air up slope heats faster and rises compared with that down slope.

Vegetation in the area consists primarily of large sagebrush and wild grasses. Wildlife observed at ANL-W includes pronghorn antelope, deer, elk, coyotes, and small mammals, as well as various species of birds and reptiles (Ref. 1).

\subsection{ANL-W Facilities}

The present facility consists of seven major research complexes: the Experimental Breeder Reactor No. 2 (EBR-II), the Transient Reactor Test Facility (TREAT), the Zero Power Physics Reactor (ZPPR), the Fuel Manufacturing Facility (FMF), the Hot Fuel Examination Facility (HFEF), the Fuel Conditioning Facility (FCF), and the Laboratory and Office Building (L\&O). A variety of chemical storage facilities, waste storage and disposal facilities, and office and maintenance facilities are also present. Plant activities require the use of many chemicals and radioactive materials, resulting in generation of a variety of hazardous, mixed and radioactive wastes. The principal facilities, and a brief description of each are listed below. Their locations are shown in Figure 2.

Experimental Breeder Reactor No. 2 (EBR-I) was a sodium-cooled reactor operated as a fuel and material irradiation facility. EBR-II proved normal-power operation of a liquid metal reactor plant. It also served as an electrical power generation station, supplying ANL-W and the INEL with part of the electrical power used at the various facilities. In October 1994, the nations' advanced liquid metal reactor program was terminated and the EBR-II reactor ceased operations in September 1994.

Transient Reactor Test Facility (TREAT) contains an air-cooled $\mathrm{UO}_{2}$-graphite fueled reactor operated to produce high power transients of very short duration for reactor safety tests. Due to limited shielding during the production of the high power transients, the control room is in a separate building approximately $1 / 2$ mile from the reactor building. The reactor building is currently the site for the operational testing of the field scale Plasma Hearth Project.

Zero Power Physics Reactor (ZPPR) is a large air-cooled fast-reactor critical assembly (a reactor core model) used to study the physics of liquid metal reactor cores. ZPPR also provides basic experimental physics data for the design of fast reactors. ZPPR has an operating power of approximately one kilowatt. This reactor is currently in a standby condition. The old Advanced Fast Source Reactor area has been decontaminated and modified into an electron microscopy laboratory. 
Figure 2. ANL-W Plot plan

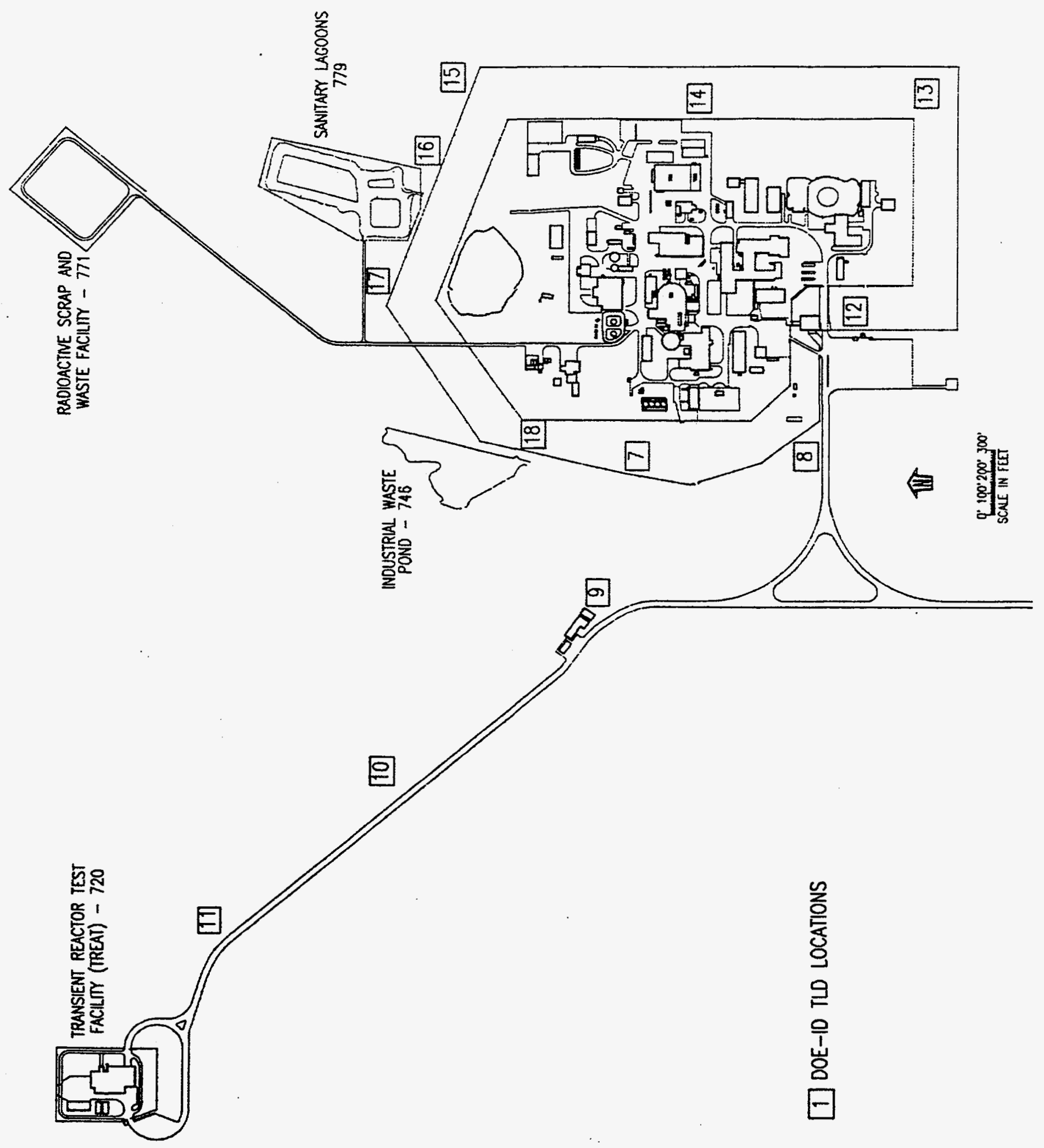


Fuel Manufacturing Facility (FMF) is designed to manufacture unirradiated or "cold" uranium fuel and conduct experiments for FCF and other facilities in a secure environment.

Hot Fuel Examination Facility (HFEF) is a large hot cell laboratory used for destructive and nondestructive examination of irradiated fuels and materials.

Fuel Conditioning Facility (FCF) is a large hot cell that has recently been modified to prove stabilization technologies for metal fuels and nuclear waste materials using an electrochemical technique. This hot cell is connected via an air lock to the EBR-II reactor, from which fuel rod subassemblies can be removed for reprocessing.

Sodium Component Maintenance Shop (SCMS). SCMS consist of a "high bay," where the cleaning operations are conducted, a "low bay" equipment annex, which houses a 15,000-L (4,000-gal) polyester-vinyl-lined suspect waste tank [with 7,500 L (2,000 gal) of useable volume], and a small annex that holds the alcohol recovery equipment. The facility is used for the removal of sodium that sticks to components that have been in contact with the EBR-II reactor sodium systems, when they are removed. Cleaning takes place in one of two systems in the high bay. One system allows for the sodium to be reacted with water, while the other system uses an alcohol wash.

Sodium Process Facility (SPF). SPF was completed in 1989 specifically for processing of FERMI sodium into sodium hydroxide (caustic) to be used for neutralization at the PUREX facility in Washington. Since then the PUREX facility has been shutdown and the need for caustic has diminished. Construction on a new addition to convert the caustic to a nonhazardous sodium carbonate powder was substantially completed in 1996. This facility will come on line in 1997 for the processing FERMI sodium and the primary and secondary sodium from the EBR-II reactor.

Laboratory and Office Building (L\&O) is a single story building housing offices in the southern portion and an analytical laboratory in the north. The analytical laboratory consists of seven shielded hot cells, seven general purpose chemistry labs, one glove box lab, two mass spectrometry labs, and three counting rooms. The primary mission of the analytical lab is to give ANL-W programs chemical and radiochemical analysis capabilities. Hot cells are used for the handling and chemical analyses of EBR-II irradiated fuels and materials.

Radioactive Scrap and Waste Facility (RSWF) is a secured facility for the interim storage of radioactive scrap and waste materials. These materials either cannot (due to contamination with sodium) or may not (due to high radiation levels) be sent to a permanent disposal facility (i.e., Radioactive Waste Management Complex (RWMC)). These materials are stored in carbon steel liners with welded lids.

The Radioactive Liquid Waste Treatment Facility (RLWTF) was brought on line in 1982 to replace the radioactive liquid evaporator in the L\&O complex. The RLWTF evaporates low-level radioactive liquid waste from all ANL-W facilities using the patented SHADE (shielded hot air drum evaporator) evaporation treatment system. Using six evaporation units, the RLWTF processes up to 30,000 gallons of liquid waste per year.

The Industrial Waste Pond (IWP) has been used since 1964 to receive waste water from several sources. The IWP is an unlined evaporative seepage pond fed by a system of drainage ditches. The 
largest sources of liquid industrial waste going to the IWP are blowdown effluents from the main cooling tower, once-through air-conditioning units, and cooling water from other sources.

The Sanitary Sewage Treatment Ponds (STP) are located north of the main facility and cover approximately two acres. There are three ponds of various sizes, one of which is maintained as an emergency overflow pond. The primary pond, constructed in 1965, receives sanitary waste directly from building 778 , the sanitary lift station, and starts the process of biological degradation of waste water. From this pond, water is directed to the secondary pond for final biological treatment. The secondary pond, constructed in 1974, is an evaporation pond with a bentonite lined base and geotextile lined sides. The sides also have a rip rap cover. The emergency overflow pond is a smaller version of the primary pond and was constructed simultaneously as the primary lagoon. Prior to 1965 sanitary wastes were discharged to individual septic systems.

\subsection{Environmental Monitoring Programs}

Lead responsibility for environmental monitoring at the INEL has been delegated to Lockheed Martin Idaho Technologies Co. (LMITCO), Environmental Monitoring Unit (EMU). Monitoring the radiological impact of INEL operations on boundary communities, such as Atomic City and Mud Lake, and on more distant localities, such as Idaho Falls and Craters of the Moon, is the responsibility of the Environmental Science and Research Foundation (ESRF). Results of both groups are reported by DOE-ID annually (Ref. 1). Monthly and year-to-date summaries of on-site radioactive liquid discharges and airborne effluent are provided by INEL contractors through the Radioactive Waste Management Information System (RWMIS). RWMIS reports are then made available to all INEL contractor organizations (Ref. 2). Summaries of nonradioactive discharges and effluent are similarly available to site contractors through the INEL Non-radiological Waste Management Information System (IWMIS) Reports (Ref. 3). ANL-W input to the RWMIS and IWMIS reports during 1996 was provided to the INEL Service Contractor (LMITCO) each month by the Environment and Restoration Department of the ANL-W Engineering Division (ED).

The ANL-W 1996 Environmental Surveillance Report provides information on levels of radioactive and nonradioactive pollutants that may have been released to the immediate ANL-W environment. This data supplements that reported in the annual INEEL Site Environmental Report. Pollutant amounts, if any, are tabulated and compared with applicable Federal and State of Idaho environmental standards and release criteria. The environmental surveillance program is described in detail in Section 2.3 of the ANL-W Environment, Safety \& Health Manual. 


\section{SUMMARY}

Environmental levels of radioactivity and other pollutants found at ANL-W during 1996 are summarized in this report. Operations at ANL-W did not affect the environment during the year. This conclusion is based on a review of analyses (of site atmosphere, potable water, waste water, and radiation levels) conducted for the 1996 calendar year. State of Idaho air and water quality standards and Federal radiation protection standards were maintained throughout 1996.

Airborne particulate gross beta and actinide concentrations detected at ANL-W were statistically the same as those measured in the distant communities. The sulfur content of fuel oil used in site boilers and the opacity of boiler stack emissions met applicable Idaho air quality standards.

Potable water from the two site production wells was sampled and analyzed quarterly for alpha, beta-gamma, and tritium activity. No significant levels of radioactivity were found. Analytical detection limits for these types of radioactivity are $3 \times 10^{-9}, 5 \times 10^{-9}$, and $4 \times 10^{-7} \mu \mathrm{Ci} / \mathrm{ml}$, respectively. These limits represent $10 \%, 5 \%$, and $0.02 \%$ of the DOE Derived Concentration Guides (Ref. 4 \& 5). This sampling was done per procedures described in the ANL-W Environmental Procedures Manual.

Water from the IWP and STPs were analyzed from January through December for alpha, beta-gamma, and tritium activity; only minor levels were detected. Samples from the IWP were analyzed for specific water treatment chemicals and identified waste stream constituents currently or formerly used by EBR-II. Water samples from the STPs were also analyzed for Biochemical Oxygen Demand, Dissolved Oxygen, temperature and pH. All IWP and STP data were normal and comparable with levels measured in previous years.

Because of the shutdown of the EBR-Il reactor, cooling tower water flow to the IWP ceased in mid 1995. The IWP level began a steady decline throughout the following two years, and became completely dry in late September. This presented a unique opportunity to conduct a radiological survey of the bottom sediments. General housekeeping activities, such as removal of submerged trash and old sample pipes was also done. A preventive maintenance operation in October discharged approximately 468,000 gallons back into the pond and brought the level to about 1.5 feet.

Due to funding reductions, no groundwater, surface soil, sediment, or vegetation samples were collected in 1996. It is hoped that additional funding for these activities will be found in FY 97.

Thermoluminescent dosimeters, posted along the site security perimeter by DOE-ID, registered exposures only slightly higher than background levels measured in distant communities. Dosimeters posted at TREAT showed radiation levels comparable to those along the site security perimeter. ANL-W internal monitoring results are also presented herein. 


\section{DATA COLLECTION, ANALYSIS AND EVALUATION}

\section{$3.1 \quad$ Atmospheric Sampling}

Levels of particulate atmospheric radioactivity at ANL-W were monitored each week using a continuous air sampler as described in Ref. 1. This sampler is found in the main parking lot, southwest of Building 701. Weekly concentrations of gross beta activity at this location ranged from $[5.1 \pm 9.0]$ $\times 10^{-15} \mu \mathrm{Ci} / \mathrm{cc}$ to $[5.1 \pm 0.2] \times 10^{-14} \mu \mathrm{Ci} / \mathrm{cc}$. These levels are consistent with the airborne concentration range for beta activity measured in distant communities of $3.69 \times 10^{-15} \mu \mathrm{Ci} / \mathrm{cc}$ to $5.4 \times \mathrm{r}^{-14} \mu \mathrm{Ci} / \mathrm{cc}$. The ANL-W annual average value of $2.81 \times 10^{-14} \mu \mathrm{Ci} / \mathrm{cc}$ is only slightly higher than the distant community annual average of $2.2 \times 10^{-14} \mu \mathrm{Ci} / \mathrm{cc}$. Those values ranged from $[3.8 \pm 1.3] \times 10^{-15} \mu \mathrm{Ci} / \mathrm{ml}$ to $[7.2 \pm 4]$ $\times 10^{-14} \mu \mathrm{Ci} / \mathrm{ml}$, with an annual average of $2.6 \times 10^{-14} \mu \mathrm{Ci} / \mathrm{ml}$. The Derived Concentration Guides for release of airborne beta emitters $\left({ }^{90} \mathrm{Sr}\right)$ to uncontrolled areas is $9 \times 10^{-12} \mu \mathrm{Ci} / \mathrm{ml}$. This standard is higher than the maximum concentration found at ANL-W by approximately two orders of magnitude.

Composites from the continuous air samplers are analyzed quarterly for actinide concentrations. These samples are taken from distant communities and near various facilities. Statistically valid detections are considered any value that is greater than twice the standard deviation. ANL-W had only one statistically valid detection. That was in the second quarter for ${ }^{239 / 240} \mathrm{Pu}$, with a value of $3.4 \pm 1.5$ $\times 10^{-18} \mu \mathrm{Ci} / \mathrm{mL}$. This value is below DOE or other regulatory limits and is similar to historical values.

Particulate atmospheric radioactivity levels are also monitored within various facilities at ANL-W. Two types of samplers are used. Filters from continuous air monitors (CAMs) are analyzed weekly while filters from fast air samplers (FASS) are analyzed twice a week. Average and maximum concentrations of gross alpha and gross beta activity at each location are listed in Appendix A. The maximum concentrations recorded were $6.41 \times 10^{-13} \mu \mathrm{Ci} / \mathrm{ml}$ and $8.99 \times 10^{-13} \mu \mathrm{Ci} / \mathrm{ml}$ for gross alpha and gross beta respectively. These levels are below the Derived Air Concentration Guides for release to uncontrolled areas of airborne beta emitters $\left({ }^{90} \mathrm{Sr}\right.$ at $\left.9 \times 10^{-12} \mu \mathrm{Ci} / \mathrm{ml}\right)$ and alpha emitters $\left({ }^{239} \mathrm{Pu}\right.$ at $\left.6 \times 10^{-12} \mu \mathrm{Ci} / \mathrm{ml}\right)$. Appendix B shows graphically annual concentrations for three outdoor FASS'. These samplers are outside the northwest corner of HFEF, outside the truck lock on the south side of FCF, and outside the reactor building. The maximum concentrations recorded from these three stations was 1.75 $\times 10^{-14} \mu \mathrm{Ci} / \mathrm{ml}$ for gross alpha and $1.23 \times 10^{-13} \mu \mathrm{Ci} / \mathrm{ml}$ gross beta.

The requirement for monitoring emissions from INEL boilers with a heat input exceeding one million BTUs per hour has been waived by DOE-ID (Ref. 8). This waiver applies to the four ANL-W boilers, which have gross input design ratings of 18 million BTUs per hour. Boiler stack $\mathrm{NO}_{\mathrm{x}}$ and opacity levels were measured by a constant monitor. The monitor is set to alarm if stack emission opacity exceeds 1.5 Ringlemann ( $30 \%$ on the Ringlemann chart). State of Idaho maximum level for visible emissions is $40 \%$ on the Ringlemann Chart for three minutes in any one hour period. No exceedances were noted for either $\mathrm{NO}_{\mathrm{x}}$ or opacity during 1996. In addition, the sulfur content of the No. 2 fuel oil used in the boilers and elsewhere on-site is below the Idaho maximum of $0.5 \%$ for this fuel grade.

\section{W.2 Water Sampling}

In August of 1993, potable water samples were collected for analyses of the National Primary Drinking Water Standards. This sampling event allowed ANL-W to apply for a waiver from future monitoring. The State of Idaho approved this waiver in March 1995. Because of obtaining this waiver, only nitrate/nitrite is required annually. In 1996 the next three-year compliance period for inorganics 
began. Samples for inorganics and nitrate/nitrite were collected in October and levels were below regulatory limits.

Distribution system samples are collected quarterly and sent, via LMITCO, to a contract lab for radiochemical analysis. None of the samples analyzed contained gross alpha, gross beta or tritium activity significantly above the respective detection limits for each type of radioactivity (Ref. 1). Detection limits for gross alpha, gross beta, and tritium are $3 \times 10^{-9}, 5 \times 10^{-9}$, and $4 \times 10^{-7} \mu \mathrm{Ci} / \mathrm{ml}$, or about 10,0.5, and 0.02 percent, respectively, of the Derived Concentration Guides (DCGs) (Ref. 4) for uncontrolled areas. Analytical results as reported by the lab are summarized in Table $\mathrm{I}$.

Because of funding constraints in fiscal year 1996, no groundwater monitoring was conducted. However, a new well was installed under the direction of the State and EPA through the INEL FFA/CO This well was completed in late 1996 and will be sampled quarterly in 1997 to provide baseline water quality data.

Installation of docks in 1995 provided the capability collect samples year round at both sanitary and industrial waste ponds. Water samples from the IWP and the STP were collected monthly from January through December. These samples were analyzed for gross alpha, gross beta, tritium, and gamma-emitting isotopes. Only low levels of beta radioactivity were detected in samples from the IWP and STP. Results are summarized in Table II.

Besides radiation analyses, IWP and STP water samples were also analyzed for chemicals previously identified in current waste streams. Analytical results are summarized in Table III.

Additional water samples collected from the secondary sewage treatment pond were analyzed for Biochemical Oxygen Demand (BOD), Dissolved Oxygen (DO), Total Suspended Solids (TSS), turbidity, specific conductivity, temperature and $\mathrm{pH}$. Results, which were similar to those noted in previous years, are summarized in Table III. Biochemical Oxygen Demand is the quantity of oxygen used in the biochemical oxidation of organic matter. It does not indicate the concentration of a specific substance, but elevated levels can suggest a pollution problem, and exercises no direct harm to aquatic life. DO and $\mathrm{pH}$ are monitored although there are no State quality standards for these characteristics.

Monthly visual inspections of the TREAT heat exchanger ditch showed no adverse effects. This area has been affected by the operations of Plasma Hearth Project. During test runs approximately $100 \mathrm{gpm}$ of non-contact cooling water was discharged through this ditch. The water collected in the low area east of TREAT to depths of up to nine inches. It then infiltrated rapidly, usually disappearing within two to three days after the cessation of discharge.

\section{Soil Sampling}

In past years, surface soil samples are analyzed to monitor background radioactivity around the site and to assess any potential buildup of radioactivity resulting from site operations. Because of funding reductions, no soil samples were collected during calendar year 1996.

\section{$3.4 \quad$ Sediment Sampling}

No sediment samples were collected in 1996. 


\begin{tabular}{||l|c|c|c||}
\hline \multicolumn{4}{|c||}{ TABLE I } \\
\hline & $\begin{array}{c}\text { Gross Alpha } \\
\text { (pCi/mL) }\end{array}$ & $\begin{array}{c}\text { Gross Beta } \\
(\mathrm{pCi} / \mathrm{mL})\end{array}$ & $\begin{array}{c}\text { Tritium } \\
(\mathrm{pCi} / \mathrm{mL})\end{array}$ \\
\hline First Quarter & $2 \pm 2$ & $7 \pm 5$ & $.09 \pm .2$ \\
\hline Second Quarter & $3 \pm 2$ & $5 \pm 3$ & $.11 \pm .2$ \\
\hline Third Quarter & $1.81 \pm .3$ & $2.08 \pm .61$ & $-40 \pm 200$ \\
\hline Fourth Quarter & $.096 \pm .52$ & $4.75 \pm .98$ & $-214 \pm 98.4$ \\
\hline 10 CFR 20 & & & $1 \times 10^{6}$ \\
\hline
\end{tabular}

a Individual analytical results are given in the monthly reports with plus or minus ( \pm ) one analytical standard deviation (1s). Small negative and other results less than or equal to $2 \mathrm{~s}$ are considered as zero. Results between 2 and $3 \mathrm{~s}$ are printed but the detection is considered as questionable. Only those results $>2$ s have been included in the average above.

b Four samples were collected from the inlet to the distribution system. 


\begin{tabular}{|c|c|c|c|c|c|c|}
\hline \multicolumn{7}{|c|}{$\begin{array}{l}\text { AVERAGE RADIOCHEMICAL ANALYSES FOR THE } \\
\text { INDUSTRIAL WASTE POND AND SANITARY LAGOONS }\end{array}$} \\
\hline & Gross Alpha $^{(a)}$ & Gross Beta $^{(a)}$ & Gamma Emitters $^{(z)}$ & Tritium $^{(a)}$ & ${ }_{239 / 240} \mathrm{Pu}(0)$ & ${ }^{228} \mathrm{Th}^{(b)}$ \\
\hline Industrial Waste Pond & $<5.9 \times 10^{.9}$ & $4.07 \times 10^{-8}$ & None detected & $<2.7 \times 10^{-6}$ & $-\cdots$ & $\ldots$ \\
\hline $\begin{array}{l}\text { Sanitary Lagoons } \\
\text { (Primary \& Secondary) }\end{array}$ & $<5.9 \times 10^{-9}$ & $5.70 \times 10^{-8}$ & None detected & $<2.7 \times 10^{-6}$ & $\ldots$ & $\ldots$ \\
\hline $\begin{array}{l}\text { Most Restrictive DCGs } \\
\text { (10 CFR 20) }\end{array}$ & $\begin{array}{c}2 \times 10^{1} \\
\left.\text { (Soluble }{ }_{239} \mathrm{Pu}\right)\end{array}$ & $\begin{array}{c}6 \times 10^{1} \\
\text { (Soluble } 226 \mathrm{Ra} \text { ) }\end{array}$ & $\begin{array}{c}1 \times 10^{3} \\
\left.\text { (Soluble }{ }^{137} \mathrm{Cs}\right)\end{array}$ & $2 \times 10^{-3}$ & $\begin{array}{c}2 \times 10^{1} \\
\left.\text { (Soluble }{ }^{239} \mathrm{Pu}\right)\end{array}$ & $\begin{array}{c}4 \times 10^{-7} \\
\text { (Soluble } \\
\text { (228 } \mathrm{Th})\end{array}$ \\
\hline
\end{tabular}

(a) Units are in $\mathrm{pCi} / \mathrm{ml}$.

(b) No analysis performed on in 1996. 


\begin{tabular}{|c|c|c|}
\hline \multicolumn{3}{|c|}{$\begin{array}{c}\text { TABLE III } \\
\text { CHEMICAL ANALYSES OF WATER FROM INDUSTRIAL } \\
\text { WASTE POND } \\
\end{array}$} \\
\hline Chemical & $\begin{array}{c}\text { Average } \\
\text { Concentration } \\
(\mu \mathrm{g} / \mathrm{mL}) \\
\end{array}$ & $\begin{array}{c}\text { Range } \\
(\mu \mathrm{g} / \mathrm{mL})\end{array}$ \\
\hline Iron & 2.52 & $<0.1-7.90$ \\
\hline Mercury & $<0.01$ & $<0.005-<0.007$ \\
\hline Sodium & 81.2 & $23-200$ \\
\hline Chloride Ion & 78.9 & $33-213$ \\
\hline Fluroide Ion & .8 & $.5-1.3$ \\
\hline Phosphate Ion & 3.14 & $<1.0-20$ \\
\hline Sulfate Ion & 342.1 & $21-852$ \\
\hline $\mathrm{pH}$ & 7.60 (s.u.) & $6.78-7.9$ \\
\hline \multicolumn{3}{|c|}{ Field Parameters } \\
\hline Temperature & 6.45 & $0.4-16.6$ \\
\hline (s.u.) & 7.41 & $6.91-8.24$ \\
\hline Specific Conductivity & 946.32 & $1.27-1637.8$ \\
\hline Dissolved Oxygen & 8.63 & $3.75 \cdot 14.37$ \\
\hline 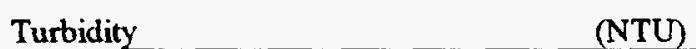 & 53.99 & $10.9-106.7$ \\
\hline
\end{tabular}

NOTE: Analyses performed on samples taken monthly, April through October. 
Normally vegetation samples are routinely collected near each corner within the site security perimeter, along the predominant wind direction at TREAT, and from three points along the banks of the IWP. Each sample is collected within approximately a one square meter area. Funding reductions did not allow for the collection of vegetation samples in 1996.

\subsection{Penetrating Radiation}

A beta-gamma radiation survey of 10 random liner caps is done at the RSWF twice a year, as directed in the ANL-W ES\&H Manual. The maximum level detected was $4 \mathrm{mR} / \mathrm{hr}$ at 1 meter. Smear results showed no contamination. In September of each year all liners containing mixed waste are also surveyed at the 1 meter level. The maximum reading for the 1996 survey was $2.2 \mathrm{mR} / \mathrm{hr}$ at liner V-42.

Twelve thermoluminescent dosimeters (TLDs) were used by LMITCO EMU to measure penetrating radiation exposures at ANL-W site boundary locations shown in Figure 2. The TLDs are mounted one meter above ground level. Six-month exposure values for these dosimeters and average background readings for TLDs posted in six distant communities are shown in Table IV (Ref. 1). The highest six-month exposure, $93 \mathrm{mR}$, was recorded three times during the year. During the first six months on TLD number 8 and on TLD numbers 7 and 15 in the second six months. The 12-month average radiation exposure at the EBR-II security perimeter was $77 \mathrm{mR}$. Average background level in distant communities during the same period was $63 \mathrm{mR}$. The 12-month exposure recorded on the TLDs posted nearest the TREAT reactor (TLD's 9, 10, 11) was $62 \mathrm{mR}$.

The drying out of the IWP presented a unique opportunity to conduct a surface survey of the previously submerged pond sediments. A surface survey was conducted in October 1996 by ANL-W RFS personnel in an effort to detect any "hotspots." No "hotspots" were detected and all levels were below instrument detection limits.

\subsection{Quality Assurance}

Data presented in this report is generated by several different organizations. Each analytical laboratory maintains their own current, comprehensive quality assurance program. Usually, internal quality control at each laboratory is maintained by the following:

- Adherence to written procedures for analytical methods,

- Documentation of program changes,

- Periodic calibrations of instruments with traceable standards,

- Periodic analysis of duplicate and matrix spikes to determine precision and accuracy,

- Analysis of quality control standards supplied from outside sources. 


\begin{tabular}{|c|c|c|}
\hline \multicolumn{3}{|c|}{ CHEMICAL ANALYSIS OF SANITARY LAGOON WATER } \\
\hline & $\begin{array}{r}\text { Average } \\
\end{array}$ & Range \\
\hline \multicolumn{3}{|l|}{ Chemistry (mg/L) } \\
\hline Iron & 0.48 & $0.30-0.70$ \\
\hline Sodium & 108.88 & $100.0-130.0$ \\
\hline Chloride & 157.75 & $119.0-187.0$ \\
\hline Fluoride & 1.08 & $<1-1.6$ \\
\hline Sulfate & 58.38 & $30.0-82.0$ \\
\hline $\mathrm{pH}(\mathrm{lab})$ & 8.06 & $7.70-8.50$ \\
\hline Biochemical Oxygen Demand (mg/L) & \multicolumn{2}{|c|}{ (Average Percent Removed $=93 \%$ ) } \\
\hline Raw Effluent & 311.25 & $235-410$ \\
\hline Final Effluent & 20.75 & $9-34$ \\
\hline \multicolumn{3}{|l|}{ Suspended Solids (mg/L) } \\
\hline Raw Effluent & 578.75 & $170-1602$ \\
\hline Final Effluent & 31.67 & $10-53$ \\
\hline \multicolumn{3}{|l|}{ Dissolved Oxygen (mg/L) } \\
\hline Raw Effluent & 6.35 & $1.27-9.05$ \\
\hline Final Effluent & 9.6 & $0.84-27.54$ \\
\hline \multicolumn{3}{|l|}{ pH (standard units) } \\
\hline Raw Effluent & 7.88 & $7.51 \cdot 8.15$ \\
\hline Final Effluent & 7.56 & $7.02-8.55$ \\
\hline \multicolumn{3}{|l|}{ Temperature $\left({ }^{\circ} \mathrm{C}\right)$} \\
\hline Raw Effluent & 15.76 & $13.4-19.4$ \\
\hline Final Effluent & 7.98 & $0.8-18.5$ \\
\hline Specific Conductivity & & \\
\hline Raw Effluent & 835.57 & $655-1025.8$ \\
\hline Final Effluent & 1071.36 & $801.3-1303$ \\
\hline Turbidity & & \\
\hline Raw Effluent & 115.33 & 87.5 - off scale \\
\hline Final Effluent & 40.86 & $89-582$ \\
\hline
\end{tabular}

NOTE: Raw effluent is sampled at the Building 778 lift station; final effluent is the mixed contents of the secondary lagoon. Both are sampled monthly. 


\begin{tabular}{||c|c|c|}
\hline \multicolumn{3}{|c|}{ TABLE V } \\
ANL-W PENETRATING RADIATION EXPOSURE \\
DATA (Ref. 2)
\end{tabular}




\subsubsection{Radioactivity Measurements}

All water analysis is done by off-site by a contract lab. This lab operates under an INEEL approved Quality Assurance Plan and is subject to biennial performance evaluations/inspections.

Performance checks of field counting instrumentation used at ANL-W to measure radioactivity are performed daily and the results are recorded in a loose leaf notebook. This instrumentation includes beta/gamma counters and alpha counters.

\subsubsection{Nonradioactive Measurements}

All chemical analyses are performed using standard EPA and/or State of Idaho approved laboratory methods. Standards prepared from Reagent Grade chemicals are analyzed and measured concurrently with each sample or sample set. These standards provide a check on analytical methods, reagents used, and recalibration of the measurement instrument with each samples set.

\section{ACKNOWLEDGMENTS}

Analytical data used in this report were provided by the ANL-W Analytical Laboratory, the LMITCO Radiological and Environmental Sciences Laboratory and Environmental Monitoring \& Water Resources section, and the Environmental Science and Research Foundation. Radiation surveys were conducted by personnel from the ANL-W Radiation, Fire and Safety Section. 


\section{REFERENCES}

1. The Idaho National Engineering Laboratory Site Environmental Report for Calendar Year 1995, DOE/ID-12082(94).

2. DOE-ID INEL Radioactive Waste Management Information System - Monthly Reports of Radioactive Waste.

3. DOE-ID INEL Industrial Waste Management Information System - Monthly Reports of Nonradioactive Waste.

4. DOE Order 5400.5, February 8, 1990.

5. Environmental Regulatory Guide for Radiological Effluent Monitoring and Environmental Surveillance, DOE/EH-0173T, January 1991.

6. Letter, R. G. Mitchell, Environmental Scientist, Environmental Science \& Research Foundation, to C. J. Martin, providing airborne actinide and weekly gross beta concentrations for offsite locations, $04 / 15 / 94$

7. Letter, L. V. Street, Supervisor, LMITCO Environmental Monitoring, to C. J. Martin, providing TLD and weekly gross beta concentrations for the ANL-W facility, 03/1 1/96.

8. Letter from R. J. Beers to R. B. O'Brien, Boiler Stack Sampling. April 12, 1976. 
APPENDIX A 


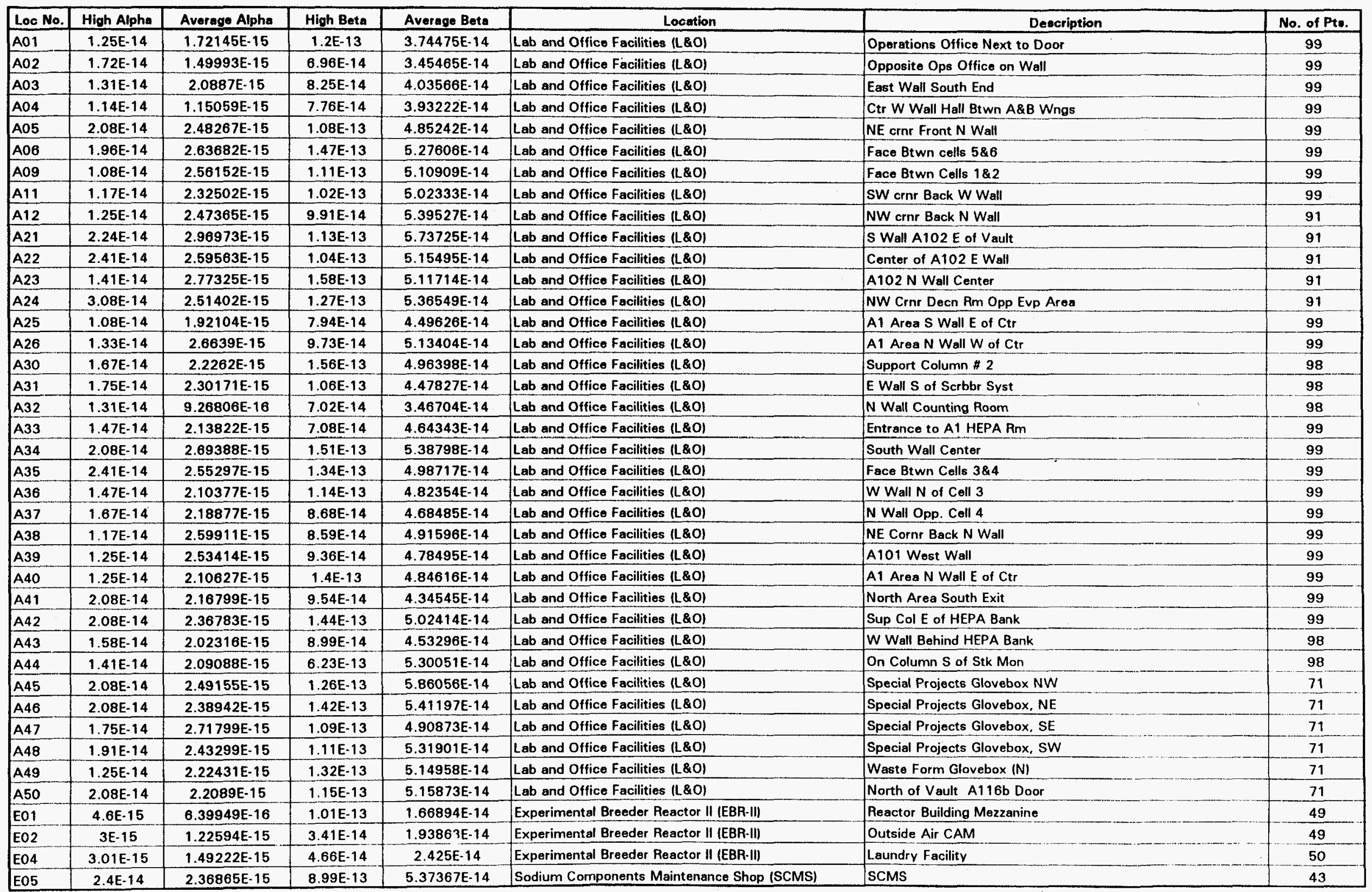


1996 Ambient Air

Radiation Levels

\begin{tabular}{|c|c|c|c|c|c|c|c|}
\hline Loc No. & High Alpha & Average Alpha & High Beta & Average Beta & $\begin{array}{r}\text { Locotion } \\
\end{array}$ & Deecription & No. of Pts. \\
\hline FO2 & $7.9 \mathrm{E} \cdot 14$ & $5.8134 \mathrm{E}-15$ & $7.15 \mathrm{E}-14$ & $3.38565 \mathrm{E}-14$ & Fuel Manufacturing Facility (FMF) & Above Hood & 95 \\
\hline $\mathrm{FO} 3$ & $3.63 \mathrm{E}-14$ & $3.50649 \mathrm{E}-15$ & $5.92 \mathrm{E}-14$ & $3.41595 E-14$ & Fuel Manufacturing Facility (FMF) & E Wall Behind Bonder & 95 \\
\hline FO4 & $5.04 \mathrm{E}-14$ & $3.88385 E-15$ & $6.49 \mathrm{E}-14$ & $3.49279 E-14$ & Fuel Manufacturing Facility (FMF) & Under NE Side Glubx & 95 \\
\hline FO5 & $4.87 \mathrm{E}-14$ & $3.62289 \mathrm{E}-15$ & $6.84 E-14$ & $3.52952 \mathrm{E}-14$ & Fuel Manufacturing Facility (FMF) & N Sd Glvbx Cnt MidRow & 95 \\
\hline FO6 & $3.67 E-14$ & $3.32937 \mathrm{E}-15$ & $5.79 \mathrm{E}-14$ & $3.09345 E-14$ & Fuel Manufacturing Facility (FMF) & N Sd Gb MidPlow Glvs & 95 \\
\hline F07 & $6.51 \mathrm{E}-14$ & $6.43504 E-15$ & $7.76 \mathrm{E}-14$ & $3.53489 \mathrm{E}-14$ & Fuel Manufacturing Facility (FMF) & W End GlvbxAbovePort & 95 \\
\hline F08 & $7.26 \mathrm{E}-14$ & $5.34185 \mathrm{E}-15$ & $8.13 \mathrm{E} \cdot 14$ & $3.59186 \mathrm{E}-14$ & Fuel Manufacturing Facility (FMF) & S Sd GBW End MdRwGlv & 95 \\
\hline FO9 & $5.55 \mathrm{E}-14$ & $5.83619 E-15$ & $9.43 E-14$ & $3.54863 E-14$ & Fuel Manufacturing Facility (FMF) & S Sd GB Cntr MdRowG & 95 \\
\hline F10 & $7.07 E-14$ & $7.60254 \mathrm{E}-15$ & $9.24 E \cdot 14$ & $3.58715 \mathrm{E}-14$ & Fuel Manufacturing Facility (FMF) & S Wall BtwnFumeTbls & 95 \\
\hline F11 & $4.69 \mathrm{E}-13$ & $2.3808 E-14$ & $1.73 E-13$ & $3.97818 \mathrm{E}-14$ & Fual Manufacturing Facility (FMFI & 5 Side of Hood \# 2 & 95 \\
\hline F12 & $1.2 \mathrm{E}-13$ & $8.41131 \mathrm{E}-15$ & $1.02 \mathrm{E}-13$ & $3.63463 \mathrm{E}-14$ & Fuel Manufacturing Facility (FMF) & On NW Cornr FurncRm & 95 \\
\hline F13 & $6.41 \mathrm{E}-13$ & $2.09408 E-14$ & $2.55 \mathrm{E}-13$ & $3.89981 E-14$ & Fuel Manufacturing Facility (FMF) & N Side of Hood \# 1 & 95 \\
\hline F14 & $1.17 \mathrm{E}-14$ & $1.76783 \mathrm{E}-15$ & $6.29 E-14$ & $3.55505 \mathrm{E}-14$ & Fuel Manufacturing Facility (FMF) & E WallCntrlRmAbvDsk & 95 \\
\hline$F 15$ & $1.57 \mathrm{E} \cdot 13$ & $8.67966 \mathrm{E}-15$ & $1.17 E-13$ & $3.8087 . \mathrm{E}-14$ & Fuel Manufacturing Facility (FMF) & N Wall W of Dbl Drs & 95 \\
\hline F16 & $7.26 \mathrm{E}-14$ & $1.83141 E-15$ & $7.27 \mathrm{E}-14$ & $3.37088 E-14$ & Fuel Manufacturing Facility (FMF) & North Wall & 95 \\
\hline F17 & $3.44 E-14$ & $1.40038 \mathrm{E}-15$ & $1.44 E-13$ & $3.34254 E-14$ & Fuel Manufacturing Facility (FMF) & E WallPit byVlid & 95 \\
\hline F18 & $1.1 \mathrm{E}-14$ & $1.13357 \mathrm{E}-15$ & $5.67 \mathrm{E}-14$ & $3.21411 \mathrm{E}-14$ & Fuel Manufacturing Facility (FMF) & E Wall by Drs ToClean Rm & 95 \\
\hline F19 & $1.16 \mathrm{E}-14$ & $1.67192 \mathrm{E}-15$ & $6.53 E-14$ & $3.35874 \mathrm{E}-14$ & Fuel Manufacturing Facility (FMF) & in Vault Above Hood & 95 \\
\hline F20 & $9.98 E-15$ & $1.52855 \mathrm{E}-15$ & $6.78 \mathrm{E}-14$ & $3.46595 \mathrm{E}-14$ & Fuel Manufacturing Facility (FMF) & SE Corner & 95 \\
\hline F21 & $1.34 \mathrm{E}-14$ & $1.10631 \mathrm{E}-15$ & $6.9 E-14$ & $3.25663 \mathrm{E}-14$ & Fual Manufacturing Facility (FMF) & SE Row of Fuel StrgeRack & 95 \\
\hline F22 & $4.41 E-15$ & $6.65337 \mathrm{E}-16$ & $5.55 \mathrm{E}-14$ & $3.23476 \mathrm{E}-14$ & Fuel Manufacturing Facility (FMF) & SW Row of Fuel Strg Rack & 95 \\
\hline F23 & $7.51 E-15$ & $1.08371 E-15$ & $5.73 E-14$ & $3.12974 \mathrm{E}-14$ & Fuel Manufacturing Facility (FMF) & West Wall Above Desk & 95 \\
\hline F24 & $1.72 \mathrm{E}-14$ & $1.21018 \mathrm{E}-15$ & $6.86 \mathrm{E}-14$ & $3.77899 \mathrm{E}-14$ & Fuel Manufacturing Facility (FMF) & East Wall & 95 \\
\hline F25 & $1 \mathrm{E}-14$ & $1.31847 E-15$ & $6.38 \mathrm{E}-14$ & $3.32316 \mathrm{E}-14$ & Fuel Manufacturing Facility (FMF) & North Wall & 95 \\
\hline F26 & $1 E-14$ & $1.26413 \mathrm{E}-15$ & $6.41 \mathrm{E}-14$ & $3.42558 \mathrm{E}-14$ & Fuel Manufacturing Facility (FMF) & South Wall & 95 \\
\hline F27 & $7.49 \mathrm{E}-15$ & $9.54095 \mathrm{E}-16$ & $6.16 \mathrm{E}-14$ & $3.17525 \mathrm{E}-14$ & Fuel Manufacturing Facility (FMF) & NW Office \#10 NoWall & 95 \\
\hline F28 & $1 \mathrm{E}-14$ & $1.56695 \mathrm{E}-15$ & $7.95 \mathrm{E}-14$ & $3.51858 \mathrm{E}-14$ & Fuel Manufacturing Facility (FMF) & \#11 SE Crnr & 95 \\
\hline F29 & $1 \mathrm{E}-14$ & $1.72799 \mathrm{E}-15$ & $6.78 \mathrm{E} \cdot 14$ & $3.58958 \mathrm{E}-14$ & Fuel Manufacturing Facility (FMF) & NE Corner & 95 \\
\hline F30 & $1 \mathrm{E}-14$ & $2.28578 \mathrm{E}-15$ & $1.49 E-13$ & $5.17204 E-14$ & Fuel Manufacturing Facility (FMF) & $S$ of Fac Mgr Office byRestRm & 93 \\
\hline L01 & $1.95 \mathrm{E}-15$ & $7.534 \mathrm{E}-16$ & $2.01 E-14$ & $1.11158 \mathrm{E}-14$ & Lab and Office Facilities (L\&O) & JR CAVE FRONT (JCF) & 50 \\
\hline $\mathrm{LO2}$ & $1.78 \mathrm{E}-15$ & $6.13554 \mathrm{E}-16$ & $1.86 \mathrm{E}-14$ & $8.8326 \mathrm{E}-15$ & Lab and Office Facilities (L8O) & JR CAVE BACK & 50 \\
\hline L03 & $1.9 \mathrm{E}-15$ & $7.28956 \mathrm{E}-16$ & $3.17 E \cdot 14$ & $1.1357 \mathrm{E}-14$ & Lab and Office Facilities (L\&O) & BASEMENT A1 FILTER RM & 50 \\
\hline L04 & $2 \mathrm{E}-15$ & $7.49696 \mathrm{E}-16$ & $2.34 E-14$ & $1.19648 E-14$ & Lab and Office Facilities (L\&O) & MAINTENANCE & 48 \\
\hline 1.05 & $2.84 E-15$ & $2.3394 \mathrm{E}-16$ & $3.62 \mathrm{E}-14$ & $7.24886 \mathrm{E}-15$ & Lab and Office Facilities (L\&O) & ALPHA (MSI) & 50 \\
\hline LO6 & $2.07 \mathrm{E}-15$ & $9.3475 E-16$ & $1.31 \mathrm{E}-14$ & $9.485 \mathrm{E}-15$ & Fuel Assembly \& Storage Building (FASB) & East Room & 4 \\
\hline LO7 & $8.55 E-14$ & $4.56392 \mathrm{E}-15$ & $3.24 E-14$ & $8.76714 \mathrm{E}-15$ & Fuel Manufacturing Facility (FMF) & FMF Southeast & 50 \\
\hline LOB & $3.35 \mathrm{E}-14$ & $4.0172 \mathrm{E}-15$ & $2.79 \mathrm{E}-14$ & $9.5265 \mathrm{E}-15$ & Fuel Manufacturing Facility (FMF) & FMF Southwest & 50 \\
\hline Lo9 & $1.99 \mathrm{E}-15$ & $5.1816 \mathrm{E}-16$ & $1.71 \mathrm{E}-14$ & $8.457 \mathrm{E}-15$ & Lab and Office Facilities (L\&O) & FMF Vault & 50 \\
\hline L10 & $1.22 \mathrm{E}-15$ & $4.05716 \mathrm{E}-16$ & $1.46 \mathrm{E}-14$ & $6.256 \mathrm{E} \cdot 15$ & Lab and Office Facilities (L\&O) & (NORTH) OUTSIDE A1 & 50 \\
\hline No1 & $1.83 E \cdot 15$ & $5.38269 E-16$ & $1.91 \mathrm{E}-14$ & $9.14122 \mathrm{E}-15$ & Hot Fuel Examination Facility (HFEF) & 008 Area & 49 \\
\hline
\end{tabular}


1996 Ambient Air

Radiation Levels

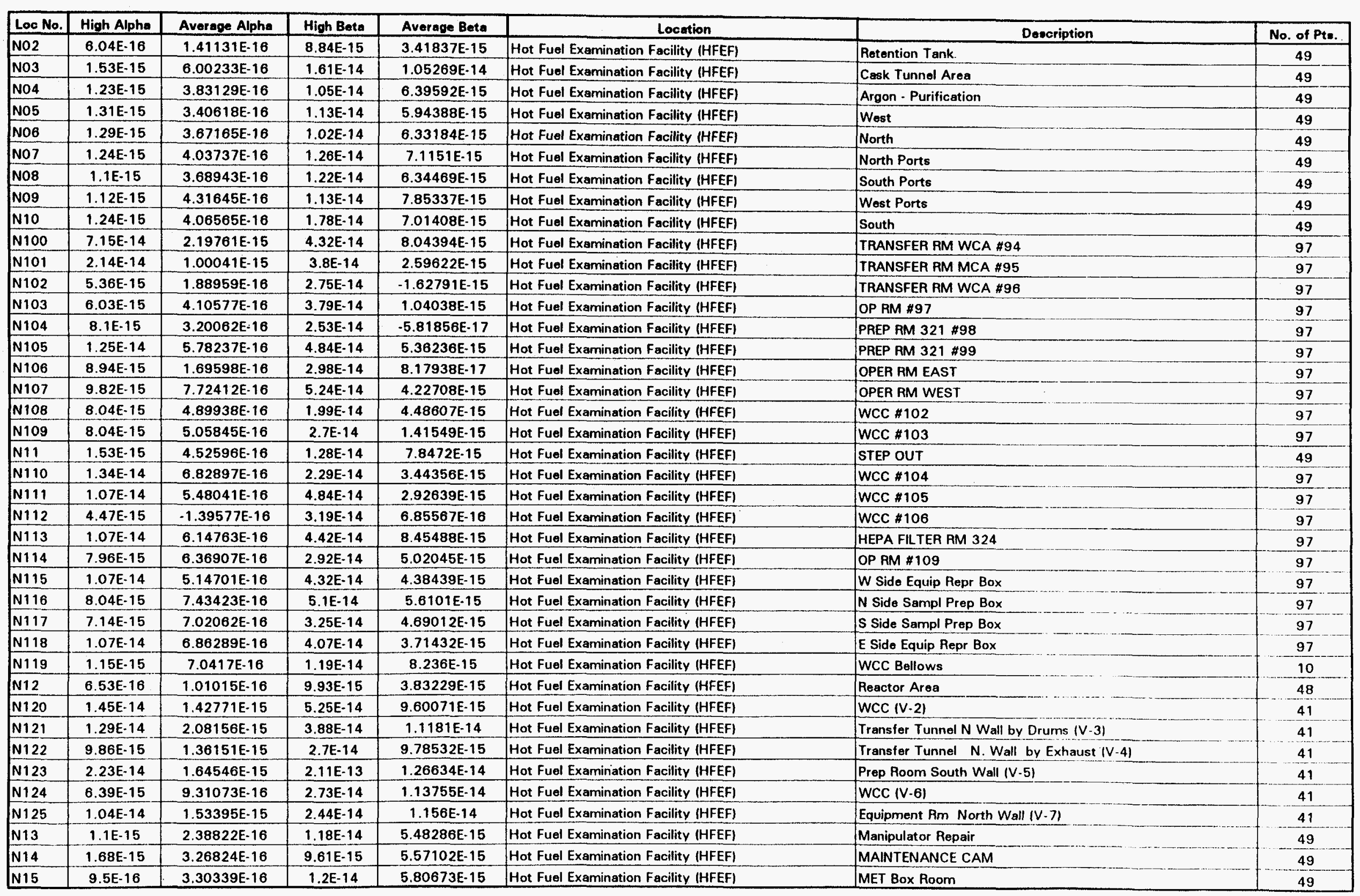




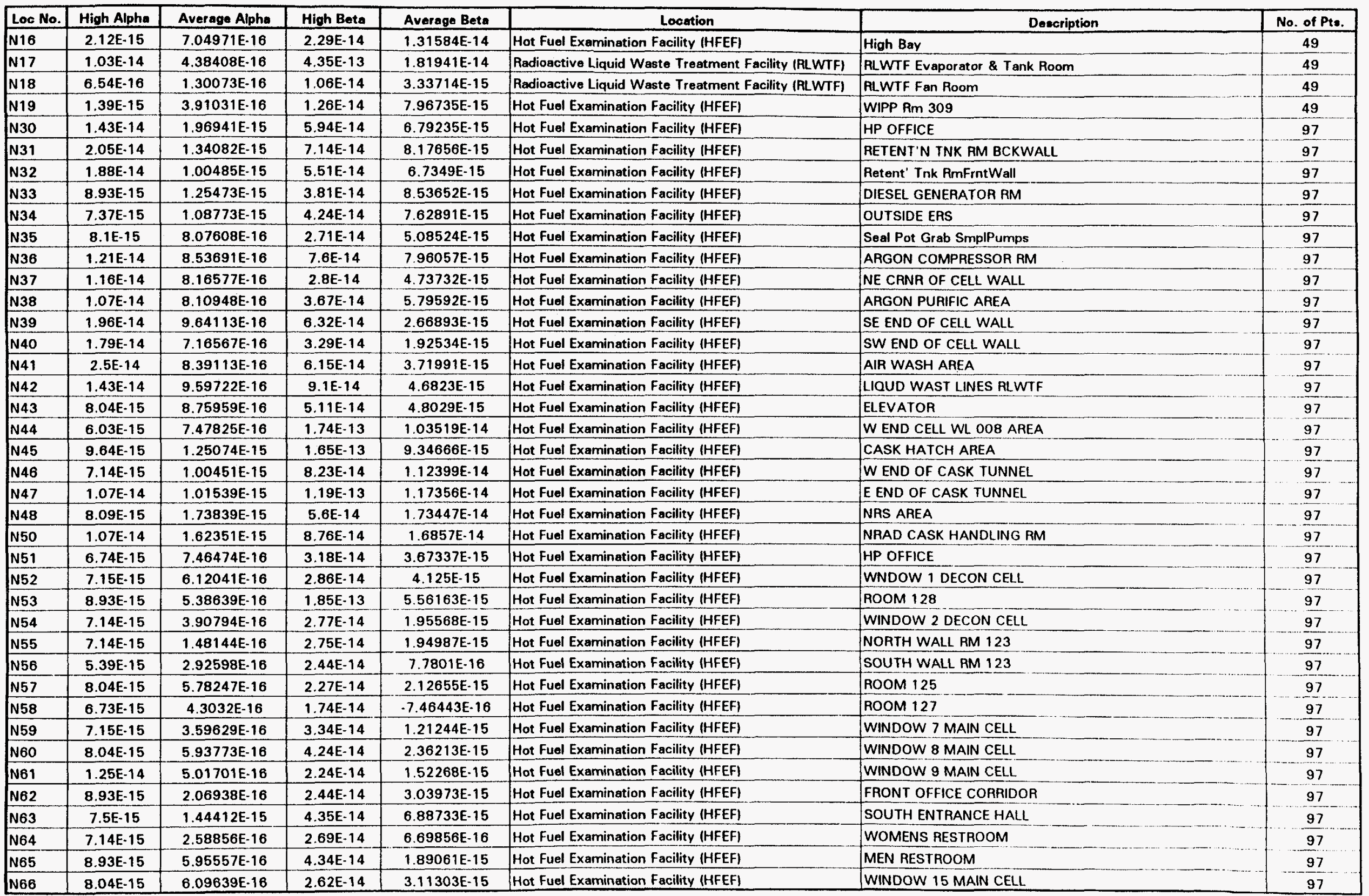




\begin{tabular}{|c|c|c|c|c|c|c|c|}
\hline Loc No. & High Alpha & Average Alpha & High Beta & Average Beta & \begin{tabular}{|c|} 
\\
Location \\
\end{tabular} & Description & No. of Pts. \\
\hline N67 & $1.07 \mathrm{E}-14$ & $4.52371 \mathrm{E}-16$ & $3.38 \mathrm{E}-14$ & $5.40431 \mathrm{E}-15$ & Hot Fuel Examination Facility (HFEF) & CONTROL ROOM & 97 \\
\hline N68 & $5.36 \mathrm{E}-15$ & $6.51371 \mathrm{E}-16$ & $2.37 E-14$ & $2.04957 \mathrm{E}-15$ & Hot Fuel Examination Facility (HFEF) & ELEVATOR & 97 \\
\hline N69 & $9.39 \mathrm{E}-15$ & $7.51856 \mathrm{E}-16$ & $2.71 \mathrm{E}-14$ & $4.2112 \mathrm{E}-15$ & Hot Fuel Examination Facility (HFEF) & WINDOW 6 DECON CELL & 97 \\
\hline N7O & $1.07 \mathrm{E}-14$ & $1.12898 \mathrm{E}-15$ & $5.1 \mathrm{E}-14$ & $1.26711 \mathrm{E}-14$ & Hot Fuel Examination Facility (HFEF) & $S$ END OF TRUCK LOCK & 97 \\
\hline N71 & $7.21 \mathrm{E}-15$ & $1.18858 \mathrm{E}-15$ & $4.76 \mathrm{E} \cdot 14$ & $9.58052 \mathrm{E}-15$ & Hot Fuel Examination Facility (HFEF) & N END OF TRUCK LOCK & 97 \\
\hline N72 & $8.93 E-15$ & $1.4887 E-15$ & $5.36 \mathrm{E} \cdot 14$ & $1.08285 \mathrm{E}-14$ & Hot Fual Examination Facility (HFEF) & OUTSIDE BLDG NW WALL & 97 \\
\hline N73 & $8.04 \mathrm{E}-15$ & $7.73072 \mathrm{E}-16$ & $2.98 \mathrm{E}-14$ & $4.74053 \mathrm{E}-15$ & Hot Fuel Examination Facility (HFEF) & DECON CELL RIP & 97 \\
\hline N74 & $8.98 \mathrm{E}-15$ & $3.08227 \mathrm{E}-16$ & $3.79 \mathrm{E}-14$ & $4.72622 \mathrm{E}-15$ & Hot Fuel Examination Facility (HFEF) & ROOM 210 & 97 \\
\hline N75 & $9.37 \mathrm{E}-15$ & $1.61588 \mathrm{E}-16$ & $2.53 \mathrm{E}-14$ & $4.63296 \mathrm{E}-15$ & Hot Fuel Examination Facility (HFEF) & N MAIN CELL RIP & 97 \\
\hline N76 & $1.16 \mathrm{E}-14$ & $5.22103 \mathrm{E}-16$ & 8.9E-14 & $6.02168 \mathrm{E}-15$ & Hot Fuel Examination Facility (HFEF) & CELL EXHAUST FILTERS & 97 \\
\hline N77 & $9.44 E-15$ & $9.7901 \mathrm{E}-16$ & $3.21 \mathrm{E}-14$ & $7.2891 \mathrm{E}-15$ & Hot Fuel Examination Facility (HFEF) & FILTER ROOM & 97 \\
\hline N78 & $9.82 \mathrm{E}-15$ & $9.87784 \mathrm{E}-16$ & $3.07 \mathrm{E}-14$ & $3.97264 \mathrm{E}-15$ & Hot Fuel Examination Facility (HFEF) & BLDG EXHAUST FILTERS & 97 \\
\hline N79 & $6.43 E-15$ & $4.1367 E-16$ & $2.79 \mathrm{E} \cdot 14$ & $2.38194 \mathrm{E}-15$ & Hot Fuel Examination Facility (HFEFI & 20 MAIN CELL WALL & 97 \\
\hline N8O & $5.36 \mathrm{E}-15$ & $2.47392 \mathrm{E}-16$ & $2.98 \mathrm{E}-14$ & 3.59263E-15 & Hot Fuel Examination Facility (HFEF) & Outsd ComAimNCellWall & 97 \\
\hline N81 & $8.04 E-15$ & $2.22165 \mathrm{E}-16$ & $2.92 \mathrm{E}-14$ & 4.47194E-15 & Hot Fuel Examination Facility (HFEF) & COMPUTER ROOM & 97 \\
\hline N82 & $7.19 \mathrm{E}-15$ & $4.43948 E-16$ & $2.78 \mathrm{E}-14$ & $1.60529 \mathrm{E}-15$ & Hot Fuel Examination Facility (HFEF) & ROOM 202 & 97 \\
\hline N83 & $7.14 \mathrm{E} \cdot 15$ & $1.53794 \mathrm{E}-16$ & $2.44 \mathrm{E}-14$ & $3.81631 E-15$ & Hot Fuel Examination Facility (HFEF) & NRAD OFFICES & 97 \\
\hline N84 & $7.14 \mathrm{E}-15$ & $3.75474 E-16$ & $3.18 E-14$ & $4.53407 E-15$ & Hot Fuel Examination Facility (HFEF) & SE CORNER CELL WALL & 97 \\
\hline N85 & $1.25 \mathrm{E}-14$ & $7.52412 \mathrm{E}-16$ & $3.53 E-14$ & $2.17992 \mathrm{E}-15$ & Hot Fuel Examination Facility (HFEF) & W END BY ELEVATOR & 97 \\
\hline N86 & $1.25 \mathrm{E}-14$ & $6.98196 \mathrm{E}-16$ & $2.67 \mathrm{E}-14$ & $6.103 E-15$ & Hot Fuel Examination Facility (HFEF) & WEST WALL HIGH BAY & 97 \\
\hline N87 & $9.02 \mathrm{E}-15$ & $4.91485 \mathrm{E}-16$ & 3.7E-14 & $6.1743 E-15$ & Hot Fuel Examination Facility (HFEF) & ELEVATOR & 97 \\
\hline N88 & $7.14 \mathrm{E}-15$ & $5.73753 \mathrm{E}-16$ & $4.61 \mathrm{E}-14$ & $5.20989 \mathrm{E}-15$ & Hot Fuel Examination Facility (HFEF) & Roof HATCH & 97 \\
\hline N89 & $8.04 E-15$ & $4.61485 \mathrm{E}-16$ & $3.01 \mathrm{E}-14$ & $2.34742 \mathrm{E}-15$ & Hot Fuel Examination Facility (HFEF) & SOUTH EAST EXIT & 97 \\
\hline N9O & $8.04 E-15$ & $4.27062 \mathrm{E}-16$ & $2.53 \mathrm{E}-14$ & $1.01771 \mathrm{E}-15$ & Hot Fuel Examination Facility (HFEF) & ANCILLARY AREA & 97 \\
\hline N91 & $7.14 \mathrm{E}-15$ & $7.21041 \mathrm{E}-16$ & $2.22 \mathrm{E}-13$ & $8.69295 \mathrm{E}-15$ & Hot Fuel Examination Facility (HFEF) & Rm 304 Support Room & 97 \\
\hline N92 & $6.7 \mathrm{E}-15$ & $3.50412 \mathrm{E} \cdot 16$ & $7.34 E-14$ & $4.87344 \mathrm{E}-15$ & Hot Fuel Examination Facility (HFEF) & ROOM 317 GLOVE WALL & 97 \\
\hline N93 & $7.14 \mathrm{E}-15$ & $7.02072 \mathrm{E}-16$ & $3.25 E-14$ & $1.12494 \mathrm{E}-15$ & Hot Fuel Examination Facility (HFEF) & OUTSIDE CART ROOM & 97 \\
\hline N94 & $9.37 \mathrm{E}-15$ & $2.4532 E-16$ & $2.4 \mathrm{E}-14$ & $2.01007 \mathrm{E}-15$ & Hot Fuel Examination Facility (HFEF) & ROOM 309 & 97 \\
\hline N95 & $5.37 \mathrm{E}-15$ & $1.00402 \mathrm{E}-16$ & $4.58 \mathrm{E}-14$ & $3.49947 \mathrm{E}-15$ & Hot Fuel Examination Facility (HFEF) & BAG-OUT ROOM 315 & 97 \\
\hline N96 & $7.14 \mathrm{E}-15$ & $3.58206 \mathrm{E}-16$ & $2.53 E-14$ & $2.54471 \mathrm{E}-15$ & Hot Fuel Examination Facility (HFEF) & SLAVE REPAIR GLOVE BOX & 97 \\
\hline N97 & $6.7 \mathrm{E} \cdot 15$ & $3.71742 \mathrm{E} \cdot 16$ & $3.53 E-14$ & 3.33723E-15 & Hot Fuel Examination Facility (HFEF) & WIPP PREP ROOM & 97 \\
\hline N98 & $8.1 E \cdot 15$ & $1.00237 \mathrm{E}-16$ & $4.88 \mathrm{E}-14$ & $9.30454 \mathrm{E}-16$ & Hot Fuel Examination Facility (HFEF) & RM 325 HP OFFICE & 97 \\
\hline N99 & $7.14 \mathrm{E}-15$ & $5.96392 \mathrm{E}-17$ & $3.32 \mathrm{E}-14$ & $9.87392 \mathrm{E}-16$ & Hot Fuel Examination Facility (HFEF) & TRANSFER AM WCA $\# 93$ & 97 \\
\hline so1 & $2.05 E-15$ & $5.98571 \mathrm{E}-16$ & $1.99 \mathrm{E}-14$ & $1.0021 \mathrm{E}-14$ & Fuel Conditioning Facility (FCF) & NE Wall by HEPA Filters & 51 \\
\hline so 2 & $1.66 \mathrm{E} \cdot 15$ & $5.64976 \mathrm{E}-16$ & $1.53 \mathrm{E}-14$ & $8.9751 E-15$ & Fuel Conditioning Facility (FCF) & 4030 NW ARGON CELL OP CORR & 51 \\
\hline So4 & $1.27 \mathrm{E}-15$ & $1.89259 \mathrm{E}-16$ & $1.64 \mathrm{E}-14$ & $4.39451 E-15$ & Fuel Conditioning Facility (FCF) & N SIDE BAGOUT ROOM & 51 \\
\hline SO5 & $1.85 \mathrm{E} \cdot 15$ & $4.091 \mathrm{E}-16$ & $1.64 \mathrm{E}-14$ & $8.25431 E-15$ & Fuel Conditioning Facility (FCF) & 4033 SO WALL LIQ WAST EO RM & 51 \\
\hline SO6 & $2.42 \mathrm{E}-15$ & 8.20969E-16 & $2.27 \mathrm{E}-14$ & $1.35359 \mathrm{E}-14$ & Fuel Conditioning Facility (FCF) & 4032 SW CORNER AIR CELL & 51 \\
\hline So7 & $1.46 \mathrm{E}-15$ & $4.27702 \mathrm{E}-16$ & $1.4 \mathrm{E}-14$ & $8.20792 \mathrm{E}-15$ & Fuel Conditioning Facility (FCF) & 4033 DECON OPS GLOVE WALL RM & 51 \\
\hline 508 & $2.63 E-15$ & $9.75275 \mathrm{E}-16$ & $6.51 E-14$ & $1.77806 \mathrm{E}-14$ & Fuel Conditioning Facility (FCF) & 4027 IBC WASH STATION \#1 & 51 \\
\hline
\end{tabular}




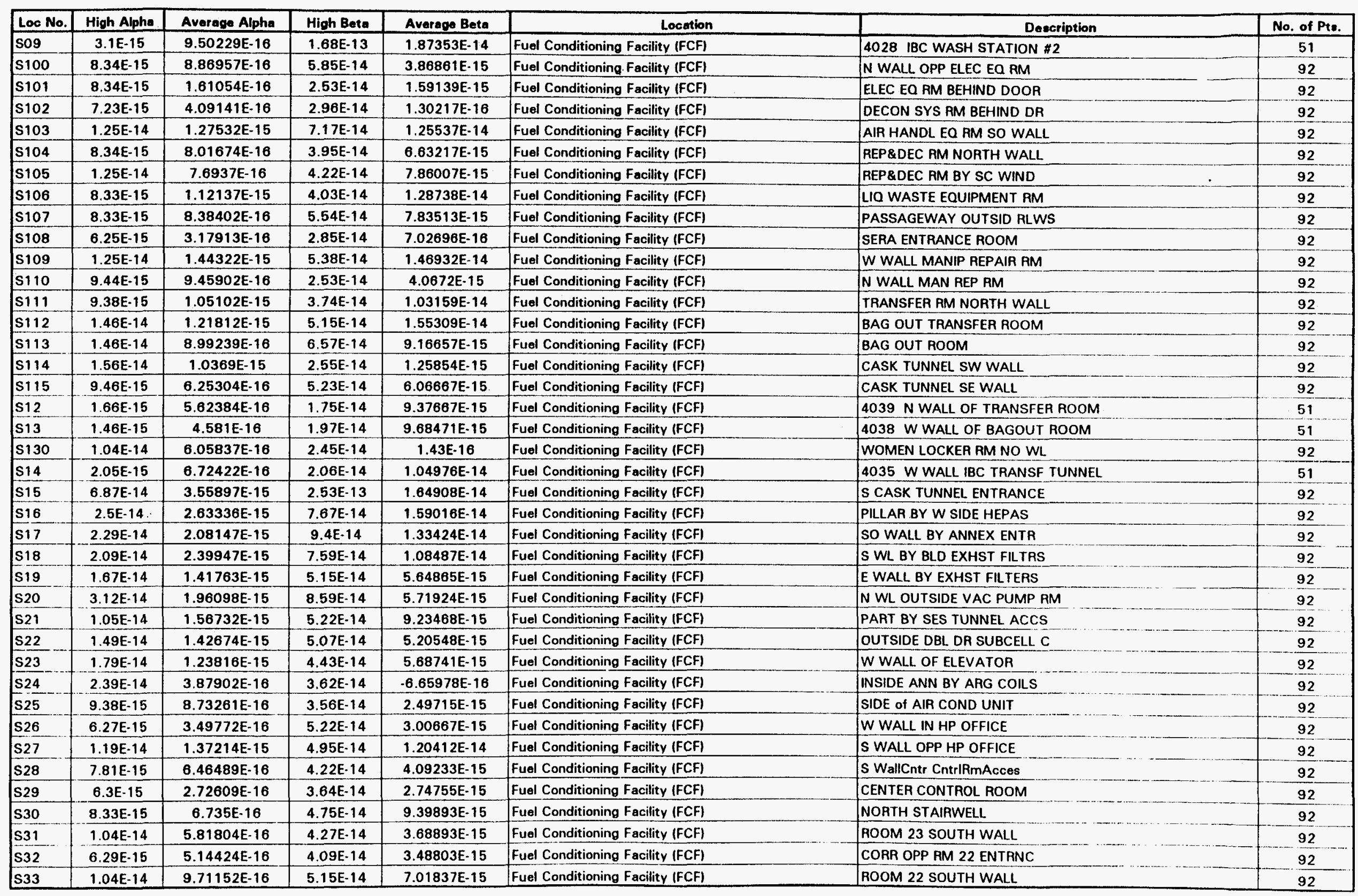




\begin{tabular}{|c|c|c|c|c|c|c|c|}
\hline Loc No. & High Alpha & Average Alpha & High Beta & Average Beta & Location & Description & No. of Pts. \\
\hline S34 & $1.25 \mathrm{E}-14$ & $7.73696 \mathrm{E}-16$ & $3.01 \mathrm{E}-14$ & $3.01622 \mathrm{E}-15$ & Fuel Conditioning Facility (FCF) & CORR OPP EQ RECV LOCK & 92 \\
\hline S35 & $2.08 \mathrm{E}-14$ & $3.16829 \mathrm{E} \cdot 15$ & $1.16 \mathrm{E}-13$ & $3.5678 \mathrm{E}-14$ & Fuel Conditioning Facility (FCF) & ELEV IN EO RECEIV LOCK & 92 \\
\hline $\mathbf{S 3 6}$ & $8.34 E-15$ & $8.19467 \mathrm{E}-16$ & $5.08 \mathrm{E}-14$ & $8.65224 \mathrm{E}-15$ & Fuel Conditioning Facility (FCF) & RM 20 EAST WALL & 92 \\
\hline $\mathbf{S 3 7}$ & $1.88 \mathrm{E}-14$ & $9.65804 \mathrm{E}-16$ & $4.03 \mathrm{E}-14$ & $4.00798 \mathrm{E}-15$ & Fuel Conditioning Facility (FCF) & OPS CONTROL RM N WALL & 92. \\
\hline $\mathbf{S 3 8}$ & $7.81 \mathrm{E}-15$ & $4.28587 \mathrm{E}-17$ & $3.32 \mathrm{E}-14$ & $4.09268 \mathrm{E}-15$ & Fuel Conditioning Facility (FCF) & CORR OPP OPS CNTRL RM & 92 \\
\hline $\mathbf{s 3 9}$ & $1.04 \mathrm{E}-14$ & $1.48374 \mathrm{E}-15$ & $6.96 \mathrm{E}-14$ & $1.48642 E-14$ & Fuel Conditioning Facility (FCF) & INSIDE S STAIRWELL & 92 \\
\hline $\mathbf{S 4 0}$ & $9.38 E-15$ & B.03043E-16 & $5.54 \mathrm{E}-14$ & $1.00063 \mathrm{E}-14$ & Fuel Conditioning Facility (FCF) & CORR OPPOSITE MENS RM & 92 \\
\hline s41 & $9.46 \mathrm{E}-15$ & $9.5337 \mathrm{E}-16$ & $3.94 \mathrm{E}-14$ & $6.77624 \mathrm{E}-15$ & Fuel Conditioning Facility (FCF) & NEXT TO WINDOW A-3 & 92 \\
\hline $\mathbf{S 4 2}$ & $9.37 \mathrm{E}-15$ & $7.50348 E-16$ & $3.94 \mathrm{E}-14$ & $7.84508 E-15$ & Fuel Conditioning Facility (FCF) & SW CORNER OF HIGH BAY & 92 \\
\hline $\mathbf{S 4 3}$ & $9.37 \mathrm{E}-15$ & $1.14616 \mathrm{E}-15$ & $4.43 E-14$ & $1.13772 \mathrm{E}-14$ & Fuel Conditioning Facility (FCF) & PCM1B AREA SO ANN EXIT & 92 \\
\hline$s 44$ & $8.34 E-15$ & $7.93609 \mathrm{E}-16$ & $4.43 E-14$ & $6.79035 \mathrm{E}-15$ & Fuel Conditioning Facility (FCF) & DECON AREA NORTH WALL & 92 \\
\hline $\mathbf{S 4 5}$ & $9.44 \mathrm{E}-15$ & $1.0145 \mathrm{E}-15$ & $3.64 \mathrm{E}-14$ & $6.80061 \mathrm{E}-15$ & Fuel Conditioning Facility (FCF) & MENS LOCKER RM N WALL & 92 \\
\hline $\mathrm{s} 47$ & $1.26 \mathrm{E}-14$ & $1.01116 \mathrm{E}-15$ & $4.75 \mathrm{E}-14$ & $1.35364 \mathrm{E}-14$ & Fuel Conditioning Facility (FCF) & DISPLAY AREA S EXIT & 92 \\
\hline$\$ 48$ & $1.75 \mathrm{E}-14$ & $3.62502 \mathrm{E}-15$ & $1.27 \mathrm{E}-13$ & $4.58362 \mathrm{E}-14$ & Fuel Conditioning Facility (FCF) & OUTSID BLDG/SE TRK LCK & 92 \\
\hline$S 49$ & $1.19 \mathrm{E}-14$ & $1.90748 \mathrm{E}-15$ & $7.59 \mathrm{E}-14$ & $2.28038 \mathrm{E}-14$ & Fuel Conditioning Facility (FCF) & INSIDE TRKLOCK W WALL & 91 \\
\hline S50 & $1.09 \mathrm{E}-14$ & $1.61674 \mathrm{E}-15$ & $4.93 E-14$ & $1.8809 \mathrm{E}-14$ & Fuel Conditioning Facility (FCF) & INSIDE TRKLOCK S WALL & 92 \\
\hline$S 51$ & $1.25 \mathrm{E}-14$ & $1.07362 \mathrm{E}-15$ & $4.64 \mathrm{E}-14$ & $3.03945 E-15$ & Fuel Conditioning Facility (FCF) & ANNEX HALLWAY & 92 \\
\hline 552 & B.33E-15 & $6.29728 E-16$ & $3.56 E-14$ & $5.18996 \mathrm{E}-15$ & Fuel Conditioning Facility (FCF) & NE CORNER E HIBAY OR & 92 \\
\hline$\$ 53$ & $9.38 \mathrm{E}-15$ & $1.33818 \mathrm{E}-15$ & $5.85 \mathrm{E}-14$ & $1.38693 \mathrm{E}-14$ & Fuel Conditioning Facility (FCF) & OPPOSITE WINDOW A-4 & 92 \\
\hline$S 54$ & $1.09 \mathrm{E}-14$ & $1.76992 E-15$ & $6.64 \mathrm{E}-14$ & $1.96074 \mathrm{E}-14$ & Fuel Conditioning Facility (FCF) & PASSAGEWAY SO WALL & 92 \\
\hline S55 & $1.04 \mathrm{E}-14$ & $1.94498 \mathrm{E}-15$ & $1.87 \mathrm{E}-13$ & $2.41378 \mathrm{E}-14$ & Fuel Conditioning Facility (FCF) & WASH STATION \#1 & 92 \\
\hline 556 & $2.34 \mathrm{E}-14$ & $1.79842 \mathrm{E}-15$ & $5.24 E-13$ & $3.28557 \mathrm{E}-14$ & Fuel Conditioning Facility (FCF) & WASH STATION \#2 & 92 \\
\hline 557 & $9.46 \mathrm{E}-15$ & $1.91566 \mathrm{E}-15$ & $8.74 E-13$ & $3.02836 \mathrm{E}-14$ & Fuel Conditioning Facility (FCF) & WASH STA CHNG RM SO WL & 92 \\
\hline 558 & $1.25 \mathrm{E}-14$ & $8.3925 E-16$ & $4.58 \mathrm{E}-14$ & $1.20042 \mathrm{E}-14$ & Fuel Conditioning Facility (FCF) & BY SCHOFIELDS HOLE & 92 \\
\hline s59 & $9.38 E-15$ & $1.51208 \mathrm{E}-15$ & $7.12 \mathrm{E}-14$ & $1.41847 \mathrm{E}-14$ & Fuel Conditioning Facility (FCF) & MOCK UP AREA SW CORR & 92 \\
\hline 560 & $9.44 \mathrm{E}-15$ & $1.56788 \mathrm{E}-15$ & $5.38 \mathrm{E}-14$ & $1.36384 \mathrm{E}-14$ & Fuel Conditioning Facility (FCF) & MOCK UP NORTH WALL & 92 \\
\hline S61 & $9.38 \mathrm{E}-15$ & $1.33761 \mathrm{E}-15$ & $3.95 E-14$ & $9.6896 \mathrm{E}-15$ & Fuel Conditioning Facility (FCF) & MOCKUP WRKSHP OFFIC DR & 92 \\
\hline $\mathrm{s} 62$ & 8.33E-15 & $8.88804 E-16$ & 2.29E-14 & $7.0625 \mathrm{E}-16$ & Fuel Conditioning Facility (FCF) & MOCK UP AREA SE CORNER & 92 \\
\hline $\mathrm{S63}$ & $8.33 E-15$ & $7.18609 \mathrm{E}-16$ & $3.01 \mathrm{E}-14$ & $9.06425 \mathrm{E}-15$ & Fuel Conditioning Facility (FCF) & NEXT TO WINDOW A-8 & 92 \\
\hline S64 & 8.33E-15 & $1.29446 \mathrm{E}-15$ & 4.27E-14 & $7.14548 \mathrm{E}-15$ & Fuel Conditioning Facility (FCF) & SOUTH END ROOM 26 & 92 \\
\hline$S 65$ & $1.56 \mathrm{E}-14$ & $1.43436 \mathrm{E}-15$ & $5.61 \mathrm{E}-14$ & $6.6828 \mathrm{E}-15$ & Fuel Conditioning Facility (FCF) & ROOM 26 NE CORNER & 92 \\
\hline 566 & $1.04 \mathrm{E}-14$ & $4.84196 \mathrm{E}-16$ & $5.34 \mathrm{E}-14$ & $8.73652 \mathrm{E}-15$ & Fuel Conditioning Facility (FCF) & CORAID OUTSD JAN CLOST & 92 \\
\hline 567 & $6.25 \mathrm{E}-15$ & $7.81652 \mathrm{E}-16$ & $4.99 \mathrm{E}-14$ & $9.54635 \mathrm{E}-15$ & Fuel Conditioning Facility (FCF) & OUTSIDE ROOM 25 & 92 \\
\hline S68 & $6.26 \mathrm{E}-15$ & $6.40696 \mathrm{E}-16$ & $4.73 \mathrm{E} \cdot 14$ & $2.52102 \mathrm{E}-15$ & Fuel Conditioning Facility (FCF) & ROOM 25 SOUTH WALL & 92 \\
\hline s69 & $1.58 \mathrm{E}-14$ & $3.08833 \mathrm{E}-15$ & $4.62 \mathrm{E}-13$ & $5.13652 \mathrm{E}-14$ & Fuel Conditioning Facility (FCF) & SO WALL CLEAN CHNG RM & 92 \\
\hline$s 70$ & $8.34 \mathrm{E}-15$ & $1.35525 \mathrm{E}-15$ & $8.28 \mathrm{E}-14$ & $2.2177 \mathrm{E}-14$ & Fuel Conditioning Facility (FCF) & STEP OUT CHANGE ROOM & 92. \\
\hline 571 & $8.34 \mathrm{E}-15$ & $9.22174 \mathrm{E}-16$ & $4.01 \mathrm{E}-14$ & $7.50845 E-15$ & Fuel Conditioning Facility (FCF) & OPER AREA SOUTH WALL & 92 \\
\hline S72 & $1.67 \mathrm{E}-14$ & $1.45587 \mathrm{E}-15$ & $6.96 \mathrm{E}-14$ & $1.76141 \mathrm{E}-14$ & Fuel Conditioning Facility (FCF) & SW CORNER OF EXIT CELL & 92 \\
\hline 573 & $1.34 \mathrm{E}-14$ & $1.86316 \mathrm{E}-15$ & $8.32 \mathrm{E} \cdot 14$ & $2.13702 \mathrm{E}-14$ & Fuel Conditioning Facility (FCF) & NE CORNER OF EXIT CELL & 92 \\
\hline $\mathrm{s} 75$ & $1.94 \mathrm{E}-15$ & $6.90498 \mathrm{E}-16$ & $2.16 \mathrm{E}-14$ & $1.14306 \mathrm{E}-14$ & Fuel Conditioning Facility (FCF) & 4034 W WALL IBC TRANSF TUNN & 51 \\
\hline
\end{tabular}




\begin{tabular}{|c|c|c|c|c|c|c|c|}
\hline 66 & 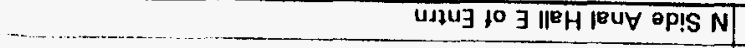 & 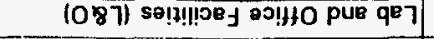 & †I-JLEGLE $\varepsilon$ & $\nabla \iota-3 \varepsilon 8.9$ & $9 L \cdot \exists l \angle 08 L^{\circ} 6$ & $\neg L-\exists E E^{\prime} L$ & $91 x$ \\
\hline 66 & IIEM ISeg fo sejuəo & $1087)$ so!n!!!oef $20 ! f 40$ pue qe7 & $t 1.322262 \varepsilon$ & $D L-\exists B L \cdot G$ & $91-3 t<\varepsilon Z 6 \cdot 9$ & $D L-\exists<l \cdot 1$ & six \\
\hline 66 & 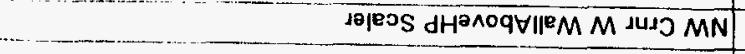 & $1087)$ se!?!!!oey as!!yo pue qe & $D\left\llcorner-\exists 6882 G^{\circ} \varepsilon\right.$ & $D L-316.9$ & $91-36989 \angle 8$ & $\nabla L-\exists G l$ & $t 1 x$ \\
\hline 66 & LOd $\theta \wedge 0 q \forall \times 0 q 0 \wedge 010$ puz S & (O87) se!!!!!2e & DL-تsटZZZ $\varepsilon$ & $D L \cdot \exists 6 L S$ & SL-JZIEOO'l & $91 \cdot 318.6$ & $E I X$ \\
\hline 66 & |әuе d!xө/dpu!4ә $\times 9 \wedge 10$ pS MS & $1087)$ so!!!!!joy & 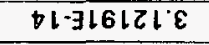 & $\$ 1.310 .9$ & $91 \cdot 366 \varepsilon 69^{\prime} 9$ & $S L \cdot 39 \varepsilon L$ & $21 x$ \\
\hline 66 & JaZuEJ JeəN XqNID op!S MS & 10871 so!!!!!pe & $\nabla L-\exists 90 \angle \nabla Z^{\prime} \varepsilon$ & $D L-36 L S$ & $S L \cdot 39 S 6+0 \cdot l$ & $D L \cdot \exists E Z \cdot l$ & $11 x$ \\
\hline 66 & PUG deON XqAID op!S MS & 10871 se!!!!!je y $20 ! 110$ pue qe 7 & $t l \cdot \exists\left\lfloor l 68 l^{\prime} \varepsilon\right.$ & $D L-\exists \angle Z L$ & $91 \cdot 39082 \cdot 9$ & $9 L-\exists D \varepsilon^{-} 8$ & $01 x$ \\
\hline 66 & 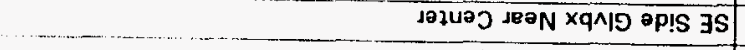 & 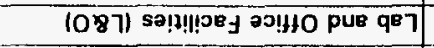 & $D L-\exists \angle 6901 \varepsilon$ & $71-316.9$ & $91-399 S \angle E^{\prime} L$ & $9 L-\exists \vdash \varepsilon \cdot 8$ & $60 x$ \\
\hline 66 & 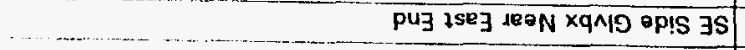 & 1087) sam!lpes os!llo pus q87 & $\nabla L-\exists \triangleright Z 0 \varepsilon \nabla \varepsilon$ & $\sqcup\left\llcorner-\exists{ }^{\prime} 9\right.$ & $9 L-369922 \mathrm{l}$ & $D L-\exists E 8: L$ & $80 x$ \\
\hline 66 & 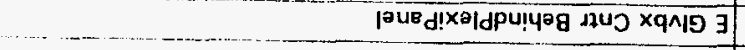 & 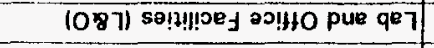 & $\nabla 1 \cdot 3 \varepsilon 8260 \varepsilon$ & $\nabla 1-39 L S$ & $91-362+690$ & $9 L-\exists ৮ \varepsilon 8$ & $\angle O X$ \\
\hline 66 & 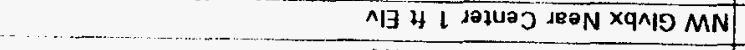 & $1087)$ se!!!!!5e & $\nabla L-\exists 9 Z Z \backslash \angle \varepsilon$ & $\pm L \cdot \exists L Z L$ & $9 L-361+101$ & $91-39 \varepsilon L$ & $90 x$ \\
\hline 66. & wod Moleg xogrnolg to pug N & 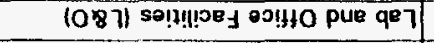 & $D 1-3 Z 12 L 2 \varepsilon$ & $11-36 L 9$ & $91 \cdot 3 \angle 1 \angle 86 \cdot 9$ & $91 \cdot 3 \angle 9 \cdot 9$ & sox \\
\hline 66 & 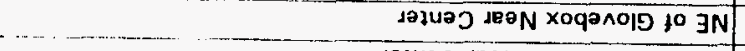 & $1087)$ sa!!!!!3e f ox!!Ho pue qe] & $\nabla \downarrow-\exists \iota D E$ & $\nabla l-\exists b \cdot \theta$ & SL- $\exists \angle G b l E^{\prime} L$ & $\nabla I-\exists \triangleright L \cdot 2$ & $t 0 x$ \\
\hline 66 & 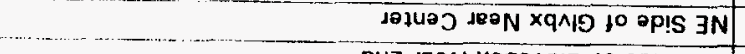 & 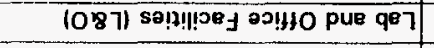 & $\nabla L-3889 \angle \varepsilon E$ & $t\llcorner-\exists \varepsilon 0.9$ & $9 \imath-39 \angle E G L^{\prime}$ & GL-ヨDE'B & $\varepsilon 0 x$ \\
\hline 66 & PUJ JEON XOQONOIS JO OP!S MN & 10871 se!!!!!je & $D L-\exists ৮ 2981 \cdot \varepsilon$ & $D l-\exists Z \nabla G$ & SL- $\exists 8 \varepsilon \angle E 0^{\circ} L$ & $t L-36 t \cdot L$ & $20 x$ \\
\hline 66 & 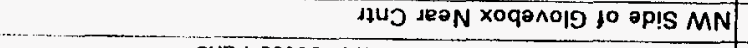 & lo87) sa!!!!jogy o & DI-JGZESE & $\nabla 1-399 \cdot 9$ & $9 L-\exists 8 Z \angle \varepsilon 0^{\circ} !$ & $D \downarrow-\exists \downarrow$ & $10 x$ \\
\hline$\underline{l}$ & 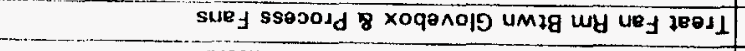 & 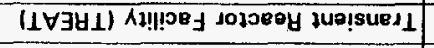 & $\nabla \downarrow-3<0 !$ & $D 1-3<01$ & Gl-39t.l & Sl-3Gd & $81 \mathrm{l1}$ \\
\hline\llcorner & 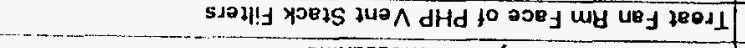 & 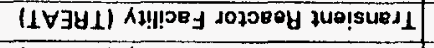 & $\nabla l \cdot 32 t \cdot 1$ & $D L-\exists Z t !$ & $9 L-\exists L \angle 8$ & $91 \cdot \exists \iota<8^{-}$ & $\angle I H$ \\
\hline $\mathbf{l}$ & ou!uezzo W WVY !UI WU ssovodd dHd & (I $\forall \exists y \perp)$ A & $\nabla 1 \cdot 32 \cdot 1$ & $71-32 \cdot 1$ & $91 \cdot 362$ & $9 L \cdot 362$ & 9ட」l \\
\hline$\iota$ & 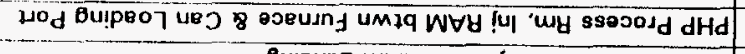 & 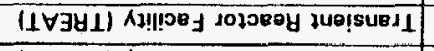 & $D l \cdot 366 \cdot 1$ & $D l-366^{\prime} l$ & $9 L \cdot \exists L L \cdot 8^{\circ}$ & $91 \cdot 3168$ & SIJ1 \\
\hline $\mathfrak{l}$ & 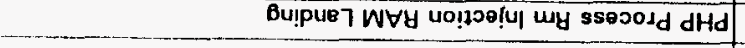 & 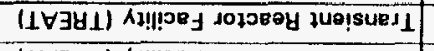 & $\nabla l \cdot 398 \cdot 1$ & $t L-398 \downarrow$ & GL-ヨGb't & 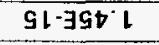 & $\nabla I J 1$ \\
\hline 1 & IIEM 4HON WH Ss0001d dHd & 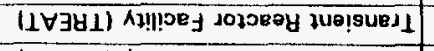 & $D 1 \cdot 366^{\circ} \mathrm{L}$ & $D L-\exists 66 !$ & $9 L-362$ & $91 \cdot 36 \cdot 2$ & $\varepsilon 1+1$ \\
\hline 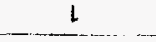 & $200_{\mathrm{J}} \mathrm{dHJ} \forall \mathrm{d} 3 \mathrm{H}$ ury $35000 \mathrm{~d} \mathrm{dHd}$ & 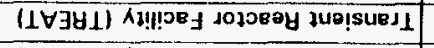 & $01 \cdot 369 \cdot 1$ & $\nabla l \cdot \exists t 9 \cdot 1$ & $9 L-\exists \varepsilon 0^{\circ} \mathrm{Z}$ & st- $\exists \varepsilon 02$ & $21 \pm 1$ \\
\hline$\stackrel{1}{.}$ & 1410 iseayinos wy ssejodd dHd & $(1 \forall \exists y \perp)$ A & $01.32 L 1$ & $01 \cdot 32 L 1$ & $91 \cdot 36 \cdot 2$ & $9 \mathrm{l}-36 \cdot \mathrm{z}$ & $11 \pm 1$ \\
\hline$\iota$ & NeM IsaM wy sseoodd dHd & 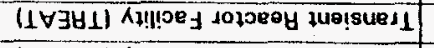 & $D 1 \cdot 32 \cdot 1$ & $51-32 !$ & $9 L-36 Z$ & $91 \cdot 36 c^{\circ}$ & OLII \\
\hline 1 & 200 y yonos xoqəAOID wy ssejodd dHd & 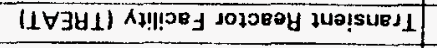 & DI. 19.1 & $D 1-319^{\circ} !$ & $91-362$ & $91 \cdot 36 \cdot z$ & $60+1$ \\
\hline 1 & 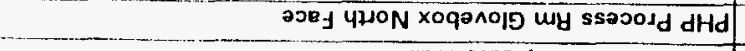 & 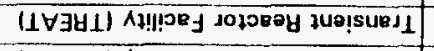 & $D 1 . \exists 8 \varepsilon z$ & $\nabla 1 \cdot \exists 8 \varepsilon \cdot 2$ & $9 l \cdot 3 l<\cdot 8$ & $91 \cdot 31<8$ & $80+1$ \\
\hline 1 & $\| 8 M$ isez wy ssojosd dHd & 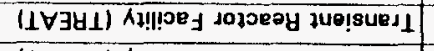 & $D L \cdot \exists L L \cdot L$ & $01-3<1.1$ & $91-36^{\circ} \mathrm{z}$ & $91 \cdot 36 \cdot 2 \cdot$ & $\angle 0 \pm 1$ \\
\hline $\mathfrak{l}$ & $\| \mathrm{eM}_{\mathrm{N}} \mathrm{seg}$ uy deJd dHd & 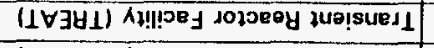 & $71-32+2$ & $\nabla 1 \cdot 32 t \cdot 2$ & $9 L-3 \varepsilon 02$ & $91-3 \varepsilon 02$ & $90 \pm 1$ \\
\hline 1 & 200 , $4210 \mathrm{~N}$ XOQFno & 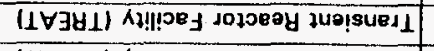 & $D L-\exists \varepsilon 0 \cdot Z$ & $D L-\exists \varepsilon 0 \cdot Z$ & GI-JGt & $91-39 t !$ & $90+1$ \\
\hline 1 & 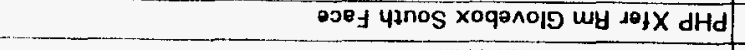 & 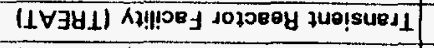 & $\nabla l \cdot \exists t 6 \cdot l$ & $71-3+6.1$ & $9 \mathrm{l}-3 \mathrm{~L} \angle 8^{\circ}$ & $9 L-3 L L B^{-}$ & $\forall 0+1$ \\
\hline 1 & NeM ymos wy $101 \mathrm{X} \mathrm{dHd}$ & $(1 \forall J 41)$ Al!! & $t 1 \cdot 32 t \cdot 1$ & $t l \cdot \exists Z t \cdot l$ & $9 l-31 L \cdot 8$ & $91-31<\cdot 8$ & $\cos 1$ \\
\hline 1 & $\|^{2} M$ Isa $M$ wy deIX dHd & $(1 \forall \exists y 1)$ An!!) & $\nabla 1-\exists 18 !$ & $D L \cdot \exists 18 !$ & $\theta l \cdot 36^{\circ} Z^{-}$ & $91 \cdot 36 \cdot 2$ & 2011 \\
\hline 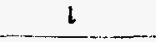 & ensopü dHd \|EM 150M +X] & 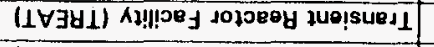 & $\nabla 1 \cdot \exists \angle E^{\prime} L$ & $D L \cdot \exists L \varepsilon l$ & $91-362$ & $9 l-\exists 6 \cdot 2$ & 1011 \\
\hline os & ㅋg HOIH & 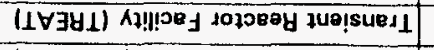 & SL-J9GEZL $L$ & $D L-399 !$ & $91-\exists 9909 \sigma^{\circ} t$ & SL-JE8 & 201 \\
\hline OS & JoOly U!EW & 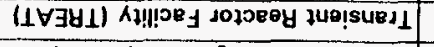 & 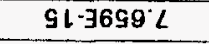 & $D L-\exists Z 9^{\prime} L$ & $9 l-\exists \operatorname{togt} 9 t$ & $9 l-3<9^{\circ} l$ & 101 \\
\hline Is & 1ld 895 090t & 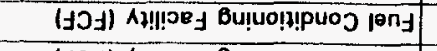 & $\not L-\exists L E I 86^{\prime} \downarrow$ & $D L \cdot \exists B L E$ & 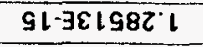 & $91-3<1 \cdot 9$ & 185 \\
\hline 19 & WOOH INOSVg JaIS HIYON & 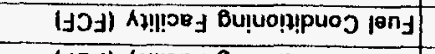 & $\forall I-\exists Z L C L I L$ & $t 1-39 t 2$ & $91-39 \angle 2<2<$ & $91 \cdot 301 \cdot 2$ & 085 \\
\hline 19 & 480O do $77 \exists J$ NOSY甘 $3 S$ LEOt & 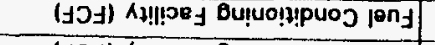 & $91-\exists t 8<L 1 \cdot 8$ & $D l \cdot 3<9 !$ & $91 \cdot 320 \angle 110$ & SL-399 $t$ & $\angle L S$ \\
\hline 19 & $\angle \forall$ \&4OJ dO 793 UIV $7 M N$ N $620 t$ & 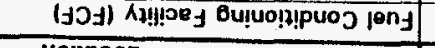 & $D I-\exists E 9 t 0 \varepsilon l$ & $+1 \cdot \exists \varepsilon 2 \cdot 2$ & $91-3 Z 6 \angle 806$ & $G L-\exists E L Z$ & $\theta<S$ \\
\hline In $10.0 \mathrm{O}$ & 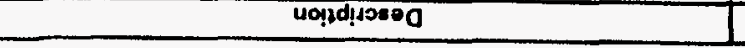 & 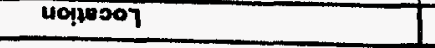 & $0109 \operatorname{cosen} y$ & $208401 \mathrm{H}$ & Eपdit OBENent & 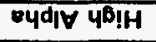 & ON 507 \\
\hline
\end{tabular}


1996 Ambient Air

Radiation Levels

\begin{tabular}{|c|c|c|c|c|c|c|c|}
\hline Loo No. & High Alpha & Average Alpho & High Beta & Average Beta & \begin{tabular}{|l} 
Location \\
\end{tabular} & Description & No. of Pte. \\
\hline $\mathbf{X 1 7}$ & $1.41 \mathrm{E}-14$ & $1.6913 \mathrm{E}-15$ & $6.9 \mathrm{E}-14$ & $3.96566 \mathrm{E}-14$ & Lab and Office Facilities (L\&O) & Rm B35 Frnace VacuumPumpCont & 99 \\
\hline$\times 18$ & $8.34 E-15$ & $1.35702 \mathrm{E}-15$ & $6.77 \mathrm{E}-14$ & $3.36348 \mathrm{E}-14$ & Lab and Office Facilities (L\&O) & Rm B35 UnderFrncV acuumSystem & 99 \\
\hline$\times 19$ & 6.67E-15 & $8.48313 \mathrm{E} \cdot 16$ & $5.73 \mathrm{E}-14$ & 3.30737E-14 & Lab and Office Facilities (L\&O) & Rm B35 BtwnNDA HEPAFiltr Bnks & 99 \\
\hline$\times 20$ & $9.81 E-15$ & $1.60918 \mathrm{E}-15$ & $7.39 E-14$ & $3.90505 E-14$ & Lab and Office Facilities (L\&O) & Rm B35 In EFL GlvbxVaCPmpCntm & 99 \\
\hline$\times 21$ & $8.34 E-15$ & $1.37387 \mathrm{E}-15$ & $6.03 E-14$ & $3.47253 \mathrm{E}-14$ & Lab and Office Facilities (L\&O) & Rm B35 GlvbxPurifSystmCabnet & 99 \\
\hline$\times 22$ & $8.76 E-15$ & $6.97343 \mathrm{E}-16$ & $4.93 E-14$ & $2.96661 \mathrm{E}-14$ & Lab and Office Facilities (L\&O) & Rm B35 AboveGloveboxSealPots & 99 \\
\hline $\mathrm{ZO2}$ & $2.55 \mathrm{E}-15$ & $8.70718 E-16$ & $2.25 E-14$ & $1.4242 \mathrm{E} \cdot 14$ & Zero Power Physics Reactor Facility (ZPPR) & Storage Building & 50 \\
\hline 203 & $3.13 E-15$ & $9.22484 \mathrm{E}-16$ & $2.09 \mathrm{E}-14$ & $1.27612 E-14$ & Zero Power Physics Reactor Facility (ZPPR) & Mockup & 50 \\
\hline 204 & $1.53 E-15$ & $1.87998 \mathrm{E}-16$ & $1.93 E-14$ & $4.1354 \mathrm{E}-15$ & Zero Power Physics Reactor Facility (ZPPR) & Work Room & 50 \\
\hline 205 & $8.77 \mathrm{E}-16$ & $6.533 \mathrm{E}-17$ & $2.77 \mathrm{E}-15$ & $3.13536 \mathrm{E}-16$ & Zoro Power Physics Roactor Facility (ZPPR) & Voult & 50 \\
\hline 206 & $2.99 E-15$ & $1.20074 \mathrm{E}-16$ & $5.25 E-15$ & $7.13881 E-16$ & Zero Power Physics Reactor Facility (ZPPR) & Gas Generating Experiment & 47 \\
\hline
\end{tabular}


APPENDIX B 


\section{ANL-W Air Sample Data}

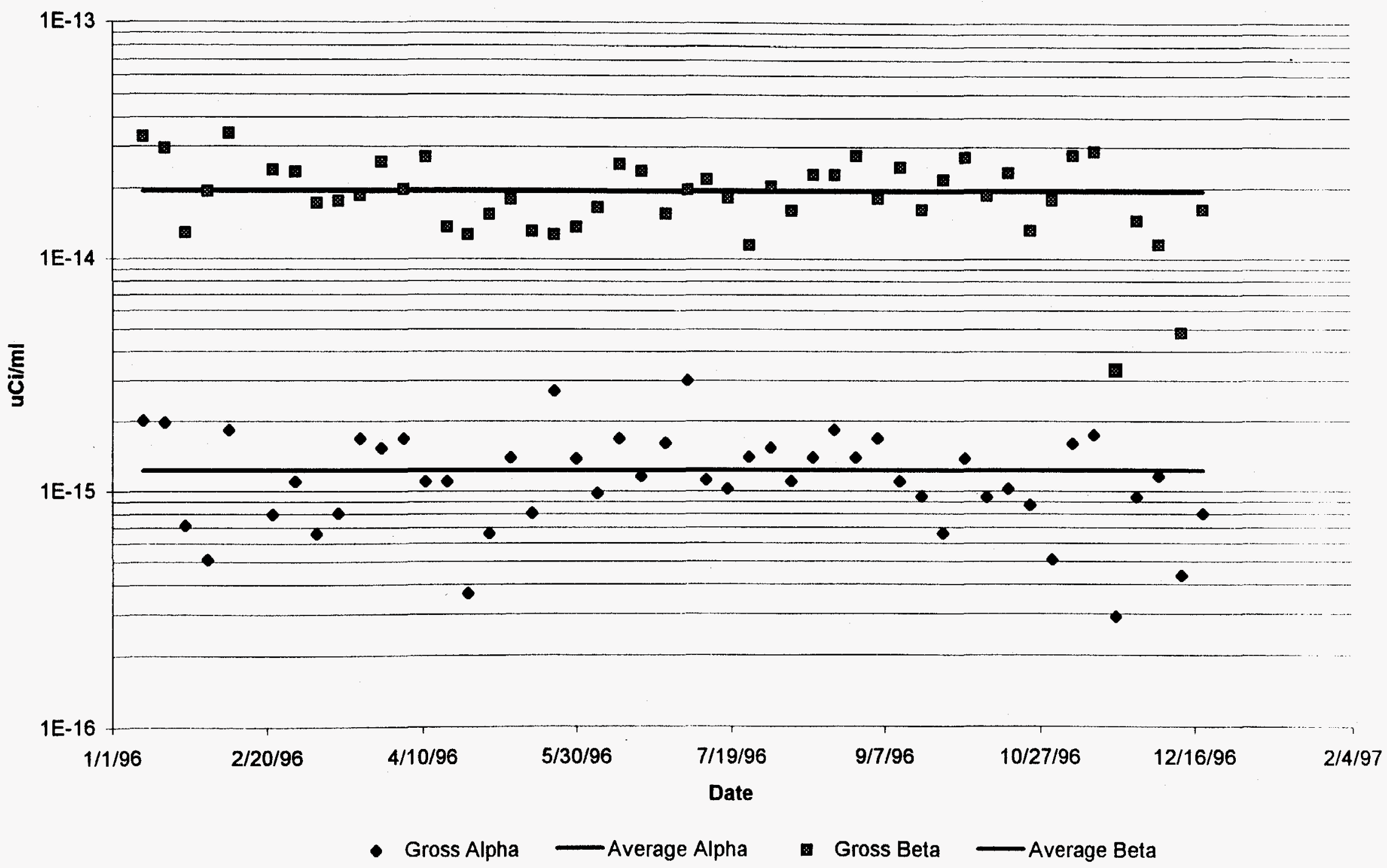


FASS 52 FCF MNFLR Outside Bldg SE/Trk Lock \#S48

\section{ANL-W Air Sample Data}

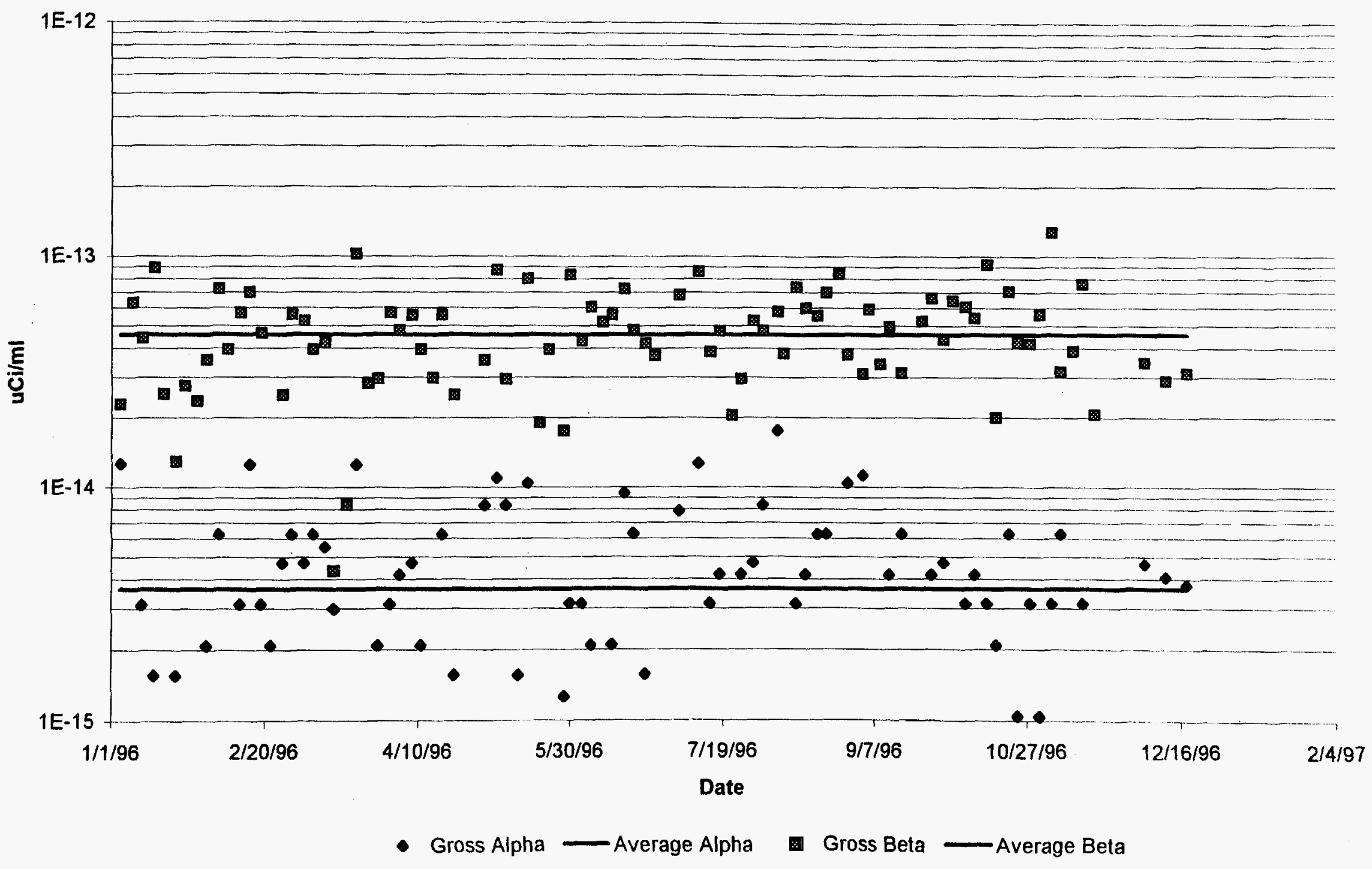


FASS 49 HFEF MNFLR Outside BIdg NW Wall \#N72

\section{ANL-W Air Sample Data}

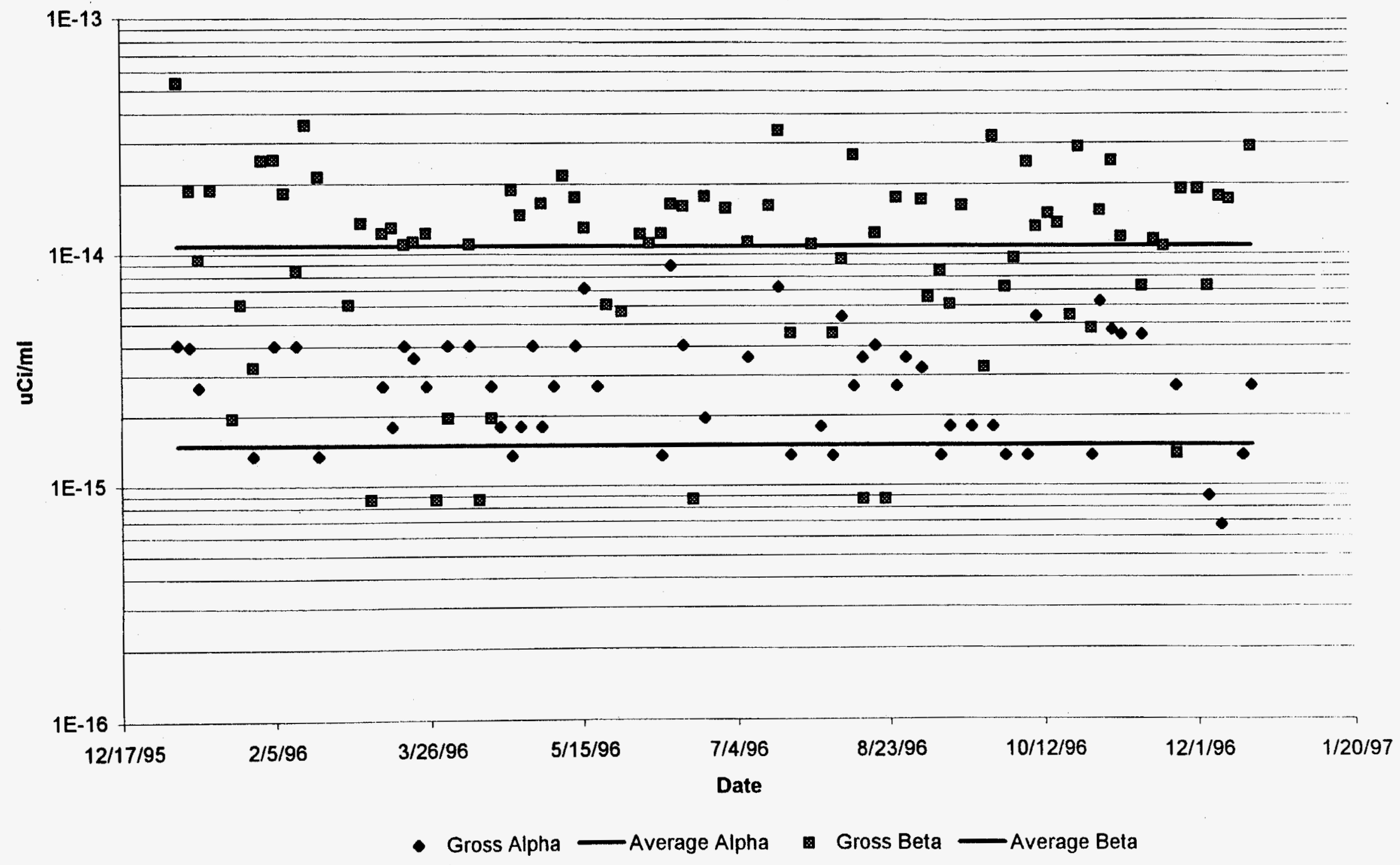


ORNL/TM-13478

\section{INTERNAL DISTRIBUTION}

\author{
1. J. J. Carbajo \\ 2. B. S. Cowell \\ 3. S. E. Fisher \\ 4. E. C. Fox \\ 5. R. G. Gilliland \\ 6. S. R. Greene \\ 7. S. A. Hodge \\ 8. R. Holdaway \\ 9. S. B. Ludwig \\ 10. G. T. Mays \\ 11. K. L. McElhaney \\ 12. G. E. Michaels \\ 13. R. N. Morris
}

\author{
14. D. L. Moses \\ 15. D. G. O'Connor \\ 16. R. T. Primm III \\ 17. R. R. Rahn \\ 18. J. D. Sease \\ 19. C. C. Southmayd \\ 20. V.S. White \\ 21. C. K. Williams \\ 22. D. L. Williams, Jr. \\ 23. Central Research Library \\ 24-25. ORNL Laboratory Records (OSTI) \\ 26. ORNL Laboratory Records-RC
}

\section{EXTERNAL DISTRIBUTION}

27. H. R. Canter, U.S. Department of Energy, MD-3, 1000 Independence Avenue SW, Washington, DC 20585 .

28. D. C. Crawford, Argonne National Laboratory, P.O. Box 2528, Idaho Falls, ID 83415.

29. J. Eichner, Science Applications International Corp., 20201 Century Blvd., Germantown, MD 20874.

30. K. Gandee, U.S. Department of Energy, MD-4, 1000 Independence Avenue SW, Washington, DC 20585.

31. C. Groome, Science Applications International Corp., 20201 Century Blvd., Germantown, MD 20874.

32. D. Hirrlinger, Science Applications International Corp., 20201 Century Blvd., Germantown, MD 20874.

33. J. V. Johnson, , U.S. Department of Energy, MD-4, 1000 Independence Avenue SW, Washington, DC 20585.

34. M. Klossner, Argonne National Laboratory, P.O. Box 2528, Idaho Falls, ID 83415.

35. S. Martinez, Argonne National Laboratory, P.O. Box 2528, Idaho Falls, ID 83415.

36. D. J. Nulton, U.S. Department of Energy, MD-4, 1000 Independence Avenue SW, Washington, DC 20585.

37. D. Peko, U.S. Department of Energy, MD-3, 1000 Independence Avenue SW, Washington, DC 20585.

38. P. T. Rhoads, U.S. Department of Energy, MD-3, 1000 Independence Avenue SW, Washington, DC 20585.

39. G. B. Stevenson, U.S. Department of Energy, MD-4, 1000 Independence Avenue SW, Washington, DC 20585.

40. J. H. Thompson, U.S. Department of Energy, MD-4, 1000 Independence Avenue SW, Washington, DC 20585.

41. T. H. Wynn, U.S. Department of Energy, ORO, P.O. Box 2001, Oak Ridge, TN 37831-8283. 


\section{DOE PUBLIC READING ROOMS}

42. Albuquerque Operations Office, TV1 Community College Library, Montoya Campus, 4700 Morris. NE, Albuquerque, NM 87111.

43. Amarillo Area Office, U.S. Department of Energy, Amarillo College, Lynn Library/Learning Center, 2201 South Washington, P.O. Box 447, Amarillo, TX 79178.

44. U.S. DOE Reading Room, Carson County Library, 401 Main Street, P.O. Box 339, Panhandle, TX 79068.

45. Chicago Operations Office, Office of the Manager/Communications, U.S. Department of Energy, 9800 South Cass Avenue, Argonne, IL 60439.

46. Idaho National Engineering and Environmental Laboratory, Idaho Public Reading Room, 1776 Science Center Drive, Idaho Falls, ID 83402.

47. Los Alamos National Laboratory, U.S. Department of Energy, c/o Los Alamos Community Reading Room, 1350 Central, Suite 101, Los Alamos, NM 87544.

48. Nevada Operations Office, U.S. Department of Energy, Public Reading Room, 2621 Losse Road, North Las Vegas, NV 89030.

49. Oak Ridge Operations Office, U.S. Department of Energy, Public Reading Room, 200 Administration Road, Room G-217, Oak Ridge, TN 37831-8501.

50. Richland Operations Office, DOE Public Reading Room, 100 Sprout Road, Room 130 West, P.O. Box 999, M/S H2-53, Richland, WA 99352.

51. Rocky Flats Office, Front Range Community College Library, 3645 West 112th Avenue, Westminster, CO 80030.

52. Sandia National Laboratory/CA, Livermore Public Library, 1000 S. Livermore Avenue, Livermore, CA 94550.

53. Savannah River Operations Office, Gregg-Graniteville Library, University of South Carolina-Aiken, 171 University Parkway, Aiken, SC 29801.

54. U.S. Department of Energy, Freedom of Information/Privacy Act Public Reading Room, Forrestal Building, Room 1E-190, 1000 Independence Avenue SW, Washington, DC 20585. 